\author{
UNIVERSIDADE DE SÃO PAULO \\ FACULDADE DE FILOSOFIA, LETRAS E CIÊNCIAS HUMANAS \\ DEPARTAMENTO DE ANTROPOLOGIA \\ PROGRAMA DE PÓS-GRADUAÇÃO EM ANTROPOLOGIA SOCIAL
}

ALEXANDRE ARAUJO BISPO

Mapas Fotográficos: memória familiar, sociabilidade e transformações urbanas em São Paulo (1920-1960)

Versão Corrigida

SÃO PAULO

2012 
UNIVERSIDADE DE SÃO PAULO

FACULDADE DE FILOSOFIA, LETRAS E CIÊNCIAS HUMANAS

DEPARTAMENTO DE ANTROPOLOGIA

PROGRAMA DE PÓS-GRADUAÇÃO EM ANTROPOLOGIA SOCIAL

\section{Mapas Fotográficos: memória familiar, sociabilidade e transformações urbanas em São Paulo (1920-1960) \\ Versão Corrigida}

ALEXANDRE ARAUJO BISPO

Dissertação de Mestrado apresentada ao Programa de PósGraduação em Antropologia Social, do Departamento de Antropologia da Faculdade de Filosofia, Letras e Ciências Humanas (FFLCH) da Universidade de São Paulo (USP), como exigência parcial para obtenção do título de Mestre em Antropologia Social, sob orientação da Prof. Dra. Fernanda Arêas Peixoto. De acordo

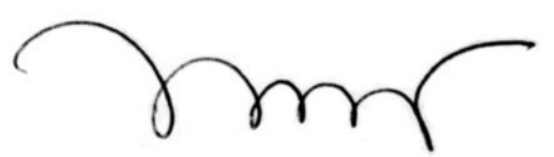

SÃO PAULO 


\section{Folha de Aprovação}

ALEXANDRE ARAUJO BISPO

Mapas Fotográficos: memória familiar, sociabilidade e transformações urbanas em São Paulo (1920-1960)

Aprovado em:

Banca Examinadora:

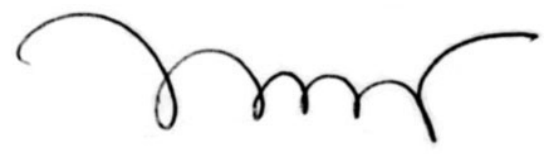

Prof. Dra. Fernanda Arêas Peixoto

Orientador

Prof. [Dra.Rose Satiko Gitirana Hikiji

Prof. [Dra. Solange Ferraz Lima 
Dedico este trabalho à minha mãe Dona Delza (in memoriam) que achava bonito quem sabia ler e escrever e a meu pai Seu Arnaldo que acha bonito quem tem boa prosa. 


\section{Agradecimentos}

À minha orientadora Dra. Fernanda Arêas Peixoto pelo grande apoio que me deu, desde quando, ainda sem ver qualquer imagem, enxergou os rendimentos deste objeto no tempo, no futuro.

Às professoras Silvia Caiuby Novaes e Solange Ferraz de Lima pela leitura crítica e sugestões que me deram no momento da qualificação.

Aos colegas do coletivo ASA: Dalila, Isabela, Júlia Goyatá, Júlia Ruiz, Lorena, Luiza, Thaís Brito, Thais Waldman, Victória, Vinicius pelas importantes observações que fizeram ao trabalho meus enormes agradecimentos. Ao Edson Alencar pela camaradagem e paciência, ao Ozias Oliveira pelas ótimas conversas, a Claúdia Roncaratti pela grande amizade. Á Marlene Laki pelo auxilio na organização da coleção. Á Francirosy Campos Barbosa Ferreira, por poucas, mas boas conversas e por ter me apresentado a Claude Guy Papavero a quem sou imensamente grato pela generosidade, pelos diálogos e estímulo constante.

Aos meus sobrinhos Carla, Cecília, Daniel, Daniele, João Victor, Júlia, Luiz Fernando, Miriam, Sabrina, Samuel, Sara, Sabrina e Vitória. Aos meus irmãos, Admilson, Adriana, Almirene, André, Amarildo, Gileno, Jaime e Norma. Ao Henrique Perez pelos livros emprestados, pelas aulas de inglês, pelas conversas sobre linguística e tantas outras.

Ao Jair Mongelli Júnior do Arquivo da Cúria Metropolitana de São Paulo, ao Márcio Batista Kawano, Rodrigo Irponi, Felipe Sabino, Dulce Ferreira, Elizabeth Brasileiro do Acervo GEDES/SESC Memórias. Á Tatiana Vasconcelos dos Santos do Serviço de Documentação Textual e Iconografia do Museu Paulista da USP.

À Ivna Fuchigami revisora deste trabalho.

Esta pesquisa foi possível graças ao financiamento da CAPES (Coordenação de Aperfeiçoamento de Pessoal de Nível Ensino Superior). 


\title{
Resumo
}

O objetivo deste trabalho é analisar uma coleção de fotografias produzidas entre os anos 1920 e 1960 em São Paulo. Nesse período Cleonice Maria Heine (1919-?), foi assunto de descrição visual e de suas imagens emergem três temas cruzados: memória familiar, cultura urbana e deslocamentos de lazer e turismo para o litoral e o campo paulistas. Por meio do consumo de fotografias que se "democratizou" no decorrer do século XX, Cleonice criou uma imagem de si, da cidade e de alguns destinos turísticos inéditos na praia e no interior. A amostragem composta de 139 imagens permite concluir que a fotografia foi para esta personagem uma plataforma de comunicação e encenação de múltiplos papéis sociais: mulher urbana, comerciária do SESC, consumidora, estudante, irmã, cunhada, turista produzindo subjetividades e sociabilidades diversas.

Palavras-chave: fotografia, memória familiar, cultura urbana, deslocamentos de lazer e turismo.

\begin{abstract}
The purpose of the present study is to analyze a collection of photographs taken between 1920 and 1960. During that length of time, Cleonice Maria Heine (1919 - ?) was the subject of visual description. From these photos three cross-related topics arise: family memory, urban culture and displacements regarding leisure and tourism towards the coast and the countryside of the State of São Paulo. Through photo consumption, which became "democratic" along the XXth century, Nelli created an image of herself, of the city itself and of some completely new tourist destinations to the beach and the countryside. The sample, formed by 139 images, allows us to conclude that photography meant to that character a stand of communication through which she played several social roles such as: urban woman, a saleswoman who enjoyed the benefits promoted by the Social Service of Commerce, consumer, student, sister, sisterin-law, tourist, by producing different subjectivity and sociability.
\end{abstract}

Keywords: photography, family memory, urban culture, displacements for leisure and tourism. 


\section{Résumé}

Le but de cette étude est d'analyser une collection de photographies prises entre les années 1920 et 1960. Pendant cette période-là, Cleonice Maria Heine (1919 - ?) a été sujet de description visuelle. Trois thèmes croisés surviennent: mémoire de famille, culture urbaine et déplacements de loisir et de tourisme vers le bord de la mer et la campagne de l'État de São Paulo. Au moyen de la consommation de photos qui est devenue « démocratique » au long du XXème siècle, Cleonice a créé une image à elle, de la ville et de quelques destinations touristiques tout neuves à la plage et en province. L'échantillon, formé par 139 images, nous permet de conclure que la photographie a été pour ce personnage le plateau de communication et de mise en scène de plusieurs rôles : femme urbaine, vendeuse qui jouissait des droits octroyés par le Service Social du Commerce, consommatrice, étudiante, sœur, belle- sœur, touriste qui produit de la subjectivité et de la sociabilité diverses.

Mots-clés : photographie, mémoire de famille, culture urbaine, déplacements de loisir et tourisme. 
Nas histórias de vida podemos acompanhar as transformações do espaço urbano; a relva que cresce livre, a ponte lançada sobre o córrego, a divisão dos terrenos, a primeira venda, o primeiro bazar. As casas crescem do chão e vão mudando: canteiros, cercas, muros, escadas, cores novas, a terra vermelha e depois o verde umbroso. Arbustos e depois árvores, calçadas, esquinas... uma casa pintada de azul que irradia a luz da manhã, os terrenos baldios, as ruas sem saída que terminam em praças ermas inacabadas por dezenas de anos (BOSI, 2003: 204) 


\section{SUMÁRIO}

INTRODUÇÃO: FOTOGRAFIA E RELATOS DE ESPAÇO.....................................1

CAPÍTULO 1: CLEONICE MARIA HEINE EM SÃO PAULO: ARQUIVAR A SI

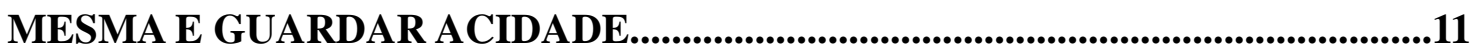

1.1. RECREAÇÃO, ESCOLA ALEMÃ E CARNAVAL ..........................................27

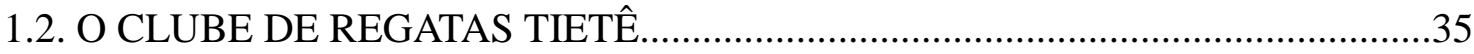

1.3. REPRESA DE SANTO AMARO: PRAIA AZUL E RIVIERA PAULISTA ..........43

1.4. O CENTRO DA CIDADE: LOCAL DE TRABALHO .........................................48

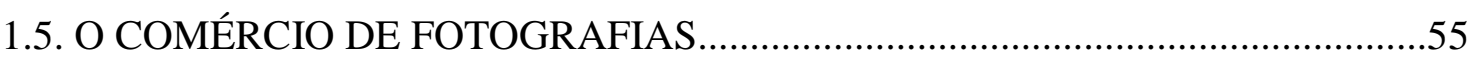

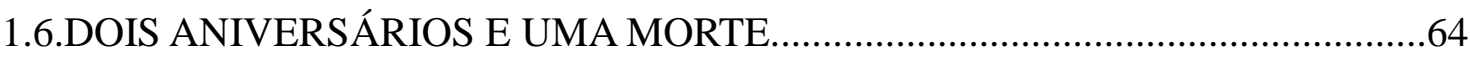

CAPÍTULO 2: MAPAS DE DESLOCAMENTOS: TURISMO NA PRAIA............71

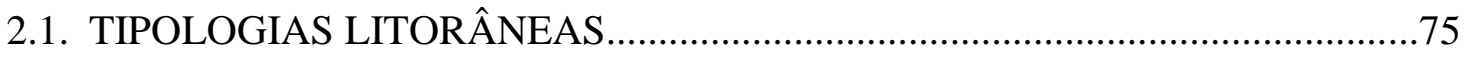

2.2. O CAMINHO DO MAR: COMUNICAÇÃO, CIRCULAÇÃO E MEMÓRIA

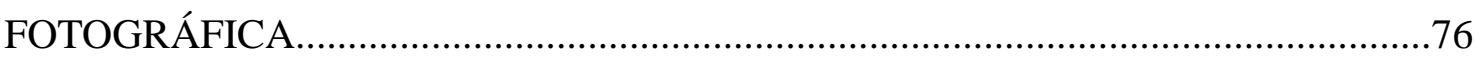

2.3. UM NOVO CAMINHO: PIQUE NIQUE NA VIA ANCHIETA.........................83

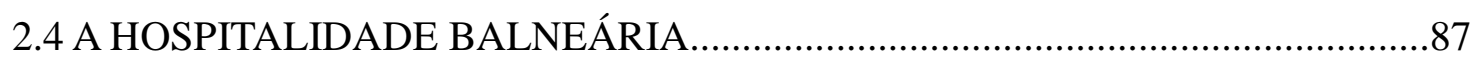

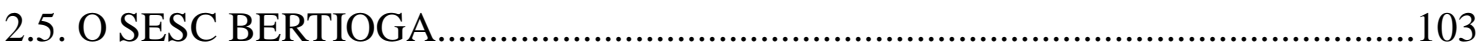

2.6.REMINISCÊNCIAS EM BERTIOGA: O PASSADO NO PRESENTE.................114

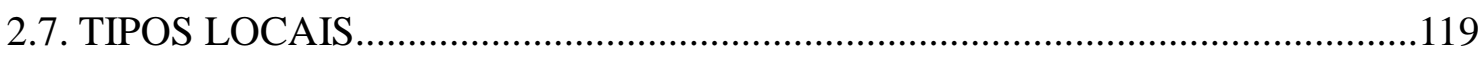

2.8. ENTRE A PRAIA E O PORTO: DUAS IMAGENS UM SENTIMENTO...........125

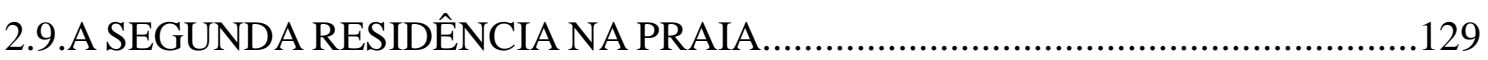

CAPÍTULO 3: MAPAS DE DESLOCAMENTOS: TURISMO NO CAMPO......147

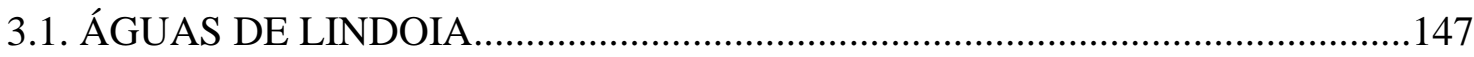

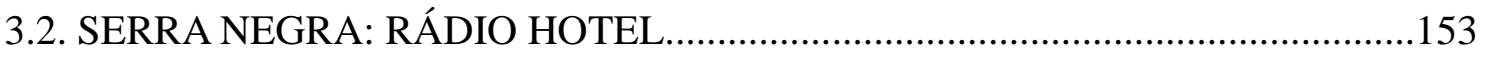




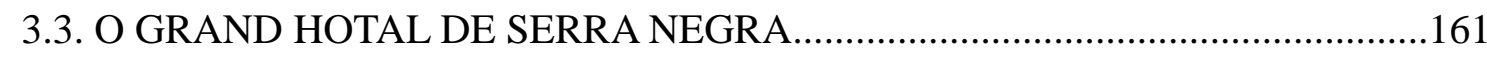

3.4. PASSEIO DA CAPELA, SÍTIO CARUSO E CACHOEIRINHA........................165

3.5. CAMPOS DO JORDÃO: ENTRE SERRAS, ARAUCÁRIAS..............................172

3.6. OS HOTÉIS TORIBA, REFÚGIO ALPINO E UMUARAMA: O INCREMENTO

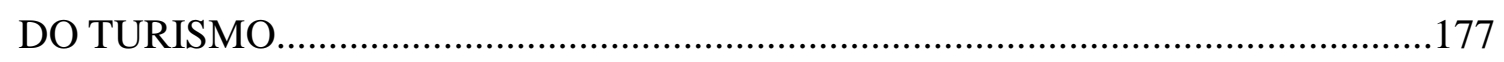

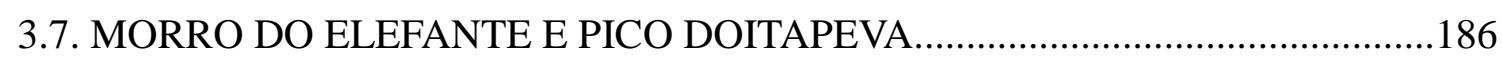

CONSIDERAÇÕES FINAIS..........................................................................193

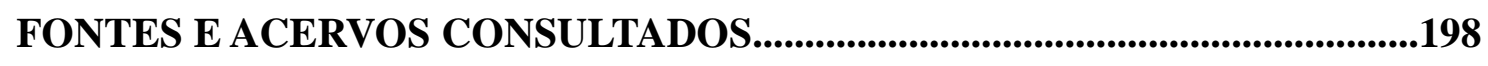

REFERÊNCIASBIBLIOGRÀFICAS....................................................................... 199 


\section{Introdução: fotografia e relatos de espaço}

De que matéria, física e existencial, são feitas essas imagens que nasceram para nos representar, para dizer, desde o início, que somos nós?

Armando Silva (2008:20)

O objetivo deste trabalho é estudar a cultura visual amadora fotográfica privada que emergiu em meados do século XX em São Paulo. Para realizá-lo analisei uma coleção de fotografias produzidas entre meados de 1920 e meados de 1960, tendo como contexto a cidade de São Paulo, o litoral e o interior paulista. Faço um relato históricobiográfico da vida de uma pessoa comum, como a grande maioria daquelas que habitaram e habitarão o mundo, valorizando, contudo, a sua experiência social. A coleção é composta de 1.000 fotografias, das quais 31 coloridas, reveladas em papel de diferentes tamanhos; um álbum fotográfico com 28 retratos e dois cartões postais coloridos, de meados dos anos 1970/80; dois negativos de acetato e 33 envelopes para acondicionar imagens. Foi originalmente constituída por Cleonice Maria Heine ${ }^{1}$, que nasceu em Santa Catarina, em 29 de maio de $1919^{2}$.

A escolha por um corte cronológico, 1920-1960, me permitiu entender as razões da grande quantidade de fotografias acumuladas por Cleonice. O período fornece representações sobre sua infância, juventude e maturidade, e corresponde ao surgimento de uma cultura visual amadora privada baseada em fotografias, que modificou a forma de os indivíduos e grupos organizarem suas memórias. Essa cultura exerceu influência sobre a memória familiar, estabeleceu padrões de representação, incrementou o mercado de produtos e serviços fotográficos, possibilitou para Cleonice a manutenção e ou criação de novos laços de amizade. Pelas fotos foi possível observar importantes

\footnotetext{
${ }^{1}$ Usarei ao longo do texto a sigla CMH para me referir à coleção. Como também utilizo imagens que pertenceram ao irmão de Cleonice, Germano Heine, toda vez que aparecer alguma referência a esta segunda coleção, utilizarei a sigla GH. Por razões éticas substitui os nomes originais das pessoas que aparecem nas fotografias.

${ }^{2}$ Conforme pesquisa feita no Registro de Batizados da Igreja de São Judas Tadeu - Jabaquara 1960, p.83, n. 2707. 7-5-18-9. Armário 28 - n. 17. Acervo da Cúria Metropolitana de São Paulo. Agradeço ao Jair, funcionário do arquivo, que foi muito solícito e paciente comigo.
} 
transformações na cidade material e nos comportamentos urbanos, como a verticalização do centro da cidade e o adensamento, nesta mesma região, do comércio de produtos e serviços fotográficos e a entrada das mulheres no mundo do trabalho. $\mathrm{O}$ início da vida profissional da personagem na indústria química em expansão a partir dos anos 1940 corresponde ao crescimento do seu consumo pessoal de fotografias e aponta para os novos papéis sociais das mulheres das camadas médias urbanas na economia de mercado nascente.

Cleonice nos deixou um eixo completo de imagens vinculadas às suas "práticas de espaço" (DE CERTEAU, 1996), na capital, no litoral e no interior paulista. Por isso a ideia de mapas fotográficos do título. Nesses relatos visuais de espaço, embora apareça o universo doméstico da casa dos pais e outros parentes, predominam, ao contrário, os lugares públicos - ruas, parques, praças, praias, pensões e hotéis no litoral e no campo. A fotografia tornou-se para Cleonice uma forma de fruição do espaço coletivo, daí a sua preocupação em identificar os locais onde esteve no estado de São Paulo. Foi a partir da constatação de que ela colecionou não apenas representações de si, mas referidas aos lugares como espaços praticados por ela, que fiz um mapeamento dos temas e deslocamentos recorrentes. Desse esforço emergiram: a memória familiar, o imaginário e cultura urbanos e os deslocamentos de lazer e turismo para o litoral e o campo. O tratamento do conjunto foi feito considerando-se todas as informações escritas encontradas na frente ou no verso das fotos, como legendas manuais, muitas feitas por Cleonice, e carimbos das empresas que comercializavam fotografias. Muitas das informações obtidas são extraídas dos materiais da própria coleção, em um trabalho de valorização dos elementos indiciais. Alguns dados foram obtidos não na coleção, mas na visita aos acervos da Cúria Metropolitana de São Paulo e do acervo GEDES SESC Memórias. No primeiro veio a confirmação da data e lugar de nascimento da personagem, no segundo as informações seguem distribuídas e devidamente identificadas ao longo dos três capítulos. Por razões éticas e de direitos autorais de uso de imagem modifiquei os nomes dos retratados, preservando suas identidades. Tal estratégia visa enfrentar o problema dos direitos autorais e de uso de imagem, mesmo que de pessoas já falecidas ${ }^{3}$. Do ponto de vista jurídico, a lei proíbe a comercialização não autorizada de imagens de pessoas e também a exposição dos retratados a situações

\footnotetext{
${ }^{3}$ Uma breve apresentação dos principais problemas relativos aos direitos de uso de imagens, quanto ao direitos autorais pode ser encontrada no endereço: http://www.sti.jus.br/portal_stj/publicacao/engine.wsp?tmp.area=398\&tmp.texto=101305 Acesso em 25/01/2012.
} 
vexatórias. Com relação aos autores das fotografias exibidas no texto há um complicador, pois não é possível garantir sua autoria. Da família Heine não há descendentes, porém, é possível que o casal Souza tenha descendentes, contudo, no período da pesquisa não os encontrei ${ }^{4}$.

O material colecionado por Cleonice nesses quarenta anos iniciais é revelador das mudanças fisionômicas de sua colecionadora e também das transformações que estavam acontecendo na vida urbana em São Paulo. Desde 1839, quando surgiu o daguerreótipo ${ }^{5}$, técnica anterior à invenção da fotografia, dois temas ganharam destaque e continuam, ainda hoje, tendo enorme relevância na produção fotográfica: os retratos de família e os registros do espaço urbano ${ }^{6}$. A importância das representações fotográficas de família nesse contexto pode ser aferida pela observação de Walter Benjamin quando se refere ao retrato: "Nenhuma obra de arte é contemplada tão atentamente em nosso tempo como a imagem fotográfica de nós mesmos, de nossos parentes próximos, de nossos seres amados" (BENJAMIN, 1994:103).

As implicações desta afirmação do autor são perfeitamente aplicáveis à coleção $\mathrm{CMH}$, em que a presença de Cleonice, de seus parentes e de pessoas próximas a ela constitui o assunto que estrutura o conjunto, destacando-se ela própria em aproximadamente 800 fotos. Por conseguinte, pode-se afirmar que a fotografia foi capaz de produzir subjetividades e sociabilidades diversas, e esse universo temático alimentou o consumo de imagens técnicas.

Conforme sabemos, as relações entre fotografia e cidade são estreitas. Basta lembrar, por exemplo, que antes mesmo do surgimento da imagem impressa, o primeiro daguerreótipo feito na América do Sul em 17 de janeiro de 1840 tinha como tema o Paço da Cidade do Rio de Janeiro e isso apenas seis meses após o anúncio oficial de sua invenção na França ${ }^{7}$. Na coleção $\mathrm{CMH}$ tanto as relações familiares quanto a cidade aparecem de maneira ostensiva entre os anos 1920-1960.

Antes de passar à discussão de como construí o corpus, quero comentar os termos "coleção" e "arquivo", tais como utilizo. Segundo Heloiza Bellotto \& Ana Maria

\footnotetext{
${ }^{4}$ Minha principal fonte de apoio foi a proprietária do antiquário.

${ }^{5}$ Trata-se de uma chapa metálica de cobre, estanho ou zinco, recoberta de fina lâmina de prata, a qual era tornada sensível à luz uma vez recoberta com sais de prata. Após a exposição na câmera obscura a chapa era 'revelada', fixada e lavada. Fez grande sucesso em todo mundo. O processo criado por Daguerre, porém não permitia cópias. KOSSOY (2010, p. 139).

${ }^{6}$ A propósito da relação entre fotografia e cidade ver: ARAÚJO (2010); ROUILLE (2009); CARVALHO e LIMA (1994 e 1997); BELLAVANCE (1997).

${ }^{7}$ Essa imagem é atribuída ao abade francês Louis Compte. Ver: JÚNIOR (2003:39).
} 
de Almeida Camargo (1996:17), uma coleção é a "reunião artificial de documentos que, não mantendo relação orgânica entre si, apresentam alguma característica comum" . Tal definição acentua o caráter documental da coleção, o que limita o tratamento específico do material fotográfico, que deveria ter, segundo essa concepção, o sentido probatório que nem sempre a fotografia carrega ${ }^{8}$. Como a fotografia é documento, representação e autorrepresentação, o ato de colecioná-la pode ser entendido como uma atividade que obedece a regras de organização baseadas na produção de efeitos estéticos (BARBUY, LIMA，CARVALHO 2002:14; CARVALHO \& LIMA， 2000; CARVALHO \& ALENCAR, 2010). Essa atividade ordenadora possibilitada pelo colecionismo traria, segundo essa concepção, um retorno psicológico prazeroso ao seu praticante (MUAZE, 2006:37). Esta acepção ampliada de coleção chama a atenção para as marcas e as intenções que o colecionador deixa na organização que faz das fotografias.

O motivo das imagens reunidas por Cleonice é basicamente ela mesma. Isso revela que colecionar fotografias de si talvez tivesse como efeito "psicológico" fixar identidades no tempo: mulher, criança, irmã, filha, estudante, secretária, madrinha, amiga, veranista, turista, comerciária do SESC, solteira. A coleção desse ponto de vista pode ser considerada uma plataforma de encenação de múltiplos papéis sociais.

O termo arquivo, por sua vez, segundo o Dicionário de Terminologia Arquvística significa: "conjunto de documentos que, independente da natureza ou do suporte, são reunidos por acumulação ao longo das atividades de pessoas físicas ou jurídicas, públicas ou privadas (BELLOTO e CAMARGO (1996: 5). Desta forma não parece difícil perceber que a coleção CMH tem algo de arquivístico, porém não é um arquivo. pois falta nela documentos como diplomas, certidões, correspondência pessoal ou profissional. Ainda assim para que fosse possível fazer a pesquisa o tratamento arquivístico foi importante. A saber: a contagem e posterior enumeração alfa numérica, a classificação por tamanho dos documentos, a montagem de uma cronologia extratificada, prática comum no tratamento de arquivos pessoais, que extrai dados biográficos da documentação do titular do arquivo. Não se pode deixar de notar, contudo, que Cleonice fez um "arquivo de vida" à medida que os itens acumulados revelam suas intenções autobiográficas (ARTIÈRES, 1998).

\footnotetext{
${ }^{8}$ Esse sentido é fundamental no tratamento arquivístico dos arquivos pessoais, por exemplo, para provar que o titular, ou sujeito acumulador, fez uma determinada atividade. Ver: CAMARGO (2009: 26-39).
} 
Meu primeiro contato com este material deu-se em $2007^{9}$, quando o comprei no Antiquário Brasil Antigo, em São Paulo ${ }^{10}$. A coleção foi adquirida pela dona da loja em 2005, ano provável da morte de Cleonice, permanecendo quase intacta ${ }^{11}$. A compra desta coleção foi motivada por um lado, pelo interesse que tenho em fotografias de família, especialmente na sua relação com a cultura urbana, por outro lado, preocupome com a preservação deste tipo de material, pois a fotografia fornece informações que não seriam acessíveis por outros meios.

Já havendo manipulado todo o conjunto construí uma amostragem de 139 fotos e duas embalagens, considerando a recorrência dos temas: memória familiar, vida urbana e deslocamentos de lazer e turismo.

Em seu desejo de ordenação, Cleonice legendou uma grande quantidade de itens, priorizando a identificação dos lugares e datas em detrimento das pessoas retratadas. Estas anotações no próprio artefato que carrega a imagem foram fundamentais para recuperar datas, eventos e lugares aos quais as fotos se referem. A organização dessas informações permitiu a construção de uma cronologia extratificada: tabela que ordena e relaciona cronologicamente os dados extraídos da frente e do verso das fotos como nomes de pessoas, datas e lugares. Ao reunir esses dados no formato de uma tabela (Tabela 1), o tratamento da fonte ficou definitivamente mais fácil.

Mostro, a seguir, a forma de organização deste documento: na primeira coluna, localizam-se informações de datação: mês, dia e ano - quando não há esses dados, aparece a sigla S/D (sem data); na segunda coluna, quando possível, estão identificados o lugar (cidade, bairro, praia ou campo) e o local (casa de parentes, hotel, empresa, escola, ponto comercial, monumentos públicos); a quantidade de fotos, por sua vez, está indicada na terceira coluna e foi útil para separar unidades e séries permitindo uma classificação codificada dos itens; esta codificação permitiu a montagem de um banco de dados para atender aos interesses imediatos de acesso ao material já digitalizado; na quarta coluna - "evento" - recupero dados relativos ao conteúdo da imagem, buscando precisar o que está sendo mostrado; finalmente, a quinta coluna informa a notação

\footnotetext{
${ }^{9}$ Pouco antes de comprar a coleção, cursei a disciplina Fotografias em acervos museológicos históricos 2006, no Museu Paulista da USP, sob a coordenação das professoras Solange Lima e Vânia Carvalho. Embora gostasse de fotografias há muito tempo, o contato com os textos e as aulas me motivaram a comprar o material.

${ }^{10}$ Esse antiquário localiza-se à Av. São João, 1821, Santa Cecília.

${ }^{11}$ É interessante pensar as razões pelas quais essa coleção ficou parada no antiquário Brasil Antigo por algum tempo, entre 2005, data provável de entrada, e 2007, ano em que a adquiri. Silvain Maresca demonstra como o circuito de arte contemporânea, bem como museus e instituições culturais ligadas à arte começaram a interessar-se pelo que ele chama de "fotografia de família". Ver: MARESCA (2003).
} 
classificatória empregada na identificação tanto física quanto digital das fotos. Essa codificação ajuda saber sobre a localização e o conteúdo de uma determinada imagem, por exemplo: A01 são os pais de Cleonice; A0117 é Cleonice fotografada por um retratista do centro de São Paulo. O documento gerado a partir dessa ordenação tem 30 páginas. Por essa razão, reproduzo aqui apenas um exemplo da sistematização feita.

\begin{tabular}{|l|l|l|l|l|}
\hline Dia/Mês/ Ano & Lugar/Local & QTD & Evento & Código \\
\hline S/D & Não identificado & 1 & $\begin{array}{l}\text { Retrato dos pais de } \\
\text { Cleonice }\end{array}$ & A01 \\
\hline $8 / 07 / 1940$ & $\begin{array}{l}\text { Edifício } \\
\text { Martinelli, 24 } \\
\text { andar, Galerias } \\
\text { Fotográficas/São } \\
\text { Paulo/ centro. }\end{array}$ & 1 & Retrato de Cleonice & A0117 \\
\hline
\end{tabular}

Tabela 1: Cronologia Extratificada.

A criação desta tabela serviu para organizar e facilitar a manipulação das fotos já que, ao começar a manuseá-las, notei a aparência caótica de envelopes e retratos soltos, o que tornava a atividade de observação e análise dos registros impraticável (foto 1). $\mathrm{O}$ documento é como um mapa dos dados obtidos pela observação sistemática.

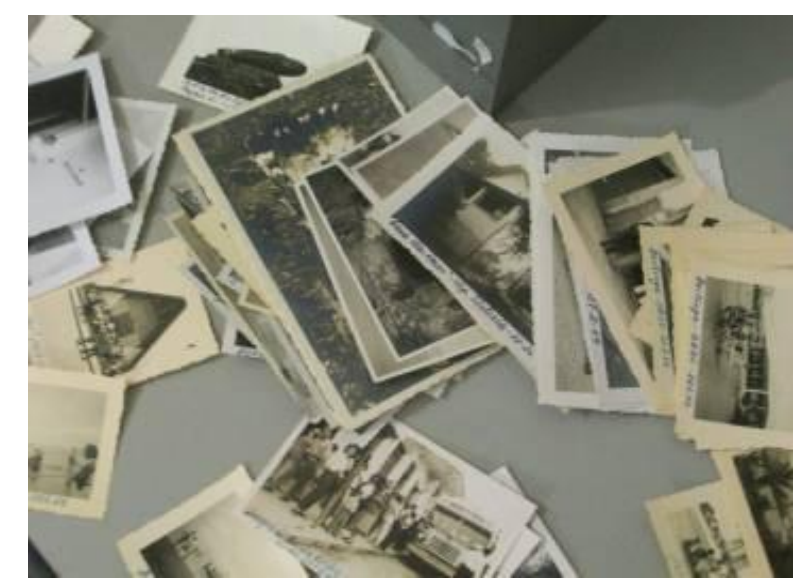

Foto 1: A coleção CMH antes do processo de organização aqui empreendido, meados de 2010. Fotografia do autor. 
As fotografias acumuladas por Cleonice não estavam guardadas em álbuns fotográficos convencionais. Por esse motivo, a impressão inicial de desorganização decorria da ausência deste dispositivo ordenador. Aspecto semelhante foi encontrado por Joon Ho Kim nas duas caixas de fotografias colecionadas por sua mãe. Como ele afirma:

\begin{abstract}
Ao início das entrevistas, Koon Ja Song, batizada Sofia, afirmou que não havia uma coleção ou acervo de retratos da família: exceto por aqueles expostos em ambientes da casa, haveria apenas um punhado de fotografias guardadas de forma desorganizada. Alegou que "tudo estava uma bagunça" e que as fotos estavam apenas grosseiramente separadas em duas caixas de sapato não identificadas (2003, p. 230).
\end{abstract}

Guardadas as diferenças entre a coleção CMH e a da mãe de Joon Ho Kim, a aparência de "bagunça" as aproxima. Contudo, a impressão é apenas superficial, pois as fotografias familiares, mesmo que acumuladas em caixas de papelão obedecem a critérios pessoais de organização que podem ser revelados com o tratamento do material. Caberia a mim, portanto, historiar essa organização original recuperando sequências e continuidades, bem como seguindo com cuidado os elementos indiciais fornecidos pelo conteúdo das imagens, pelas legendas, dimensões padronizadas, texturas dos papéis e informações carimbadas no verso das fotos, como na figura $2^{12}$.

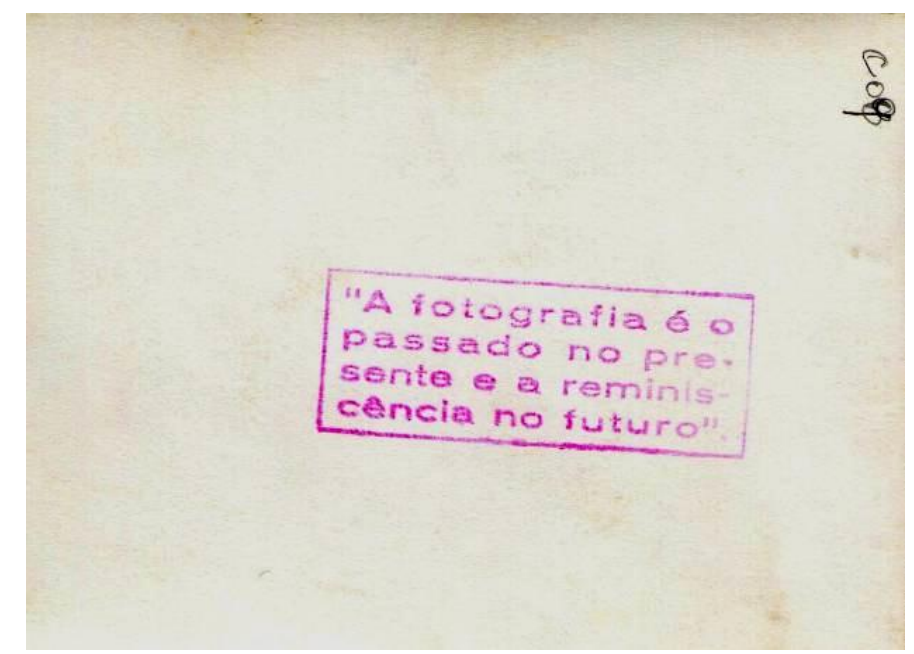

Figura 2: Frase carimbada no verso de uma foto que define o que é fotografia. A relação com o tempo está claramente expressa: passado, presente e futuro. Carimbo da Foto Velloso reportagens fotográficas. S/D.

\footnotetext{
${ }^{12}$ Sobre os procedimentos básicos de organização, manuseio e conservação de coleções fotográficas ver: FILIPPI, LIMA e CARVALHO (2002).
} 
Desta forma não parece despropositado denominar "álbum" as fotos guardadas em caixas, como indica Antonio Silva (2008) ao classificar o álbum fotográfico em três tipos - álbum lógico, álbuns soltos e álbuns em caixas ou de fotos misturadas -, mostrando que o álbum convencional é apenas um modo de ordenação formal da memória fotográfica nos arquivos domésticos, dotado de uma lógica narrativa ideal ${ }^{13}$. Os álbuns soltos, mesmo sendo depósitos desordenados, continua o autor, permitem captar outras lógicas rituais e ocasionais, pois o suporte material do álbum está ali, ainda que sem uma classificação deliberada. Finalmente, o terceiro tipo mencionado, os álbuns armazenados em caixas, guardam a consciência de álbum, porque um relator ao falar sobre ele o reorganiza.

A coleção $\mathrm{CMH}$ pertence a esta última categoria e sua colecionadora pode ser tomada como uma "relatora", uma informante em um duplo sentido da expressão: primeiro, porque ela é o motivo visual que estrutura o conjunto; segundo, porque organizou e classificou muitos dos itens acumulados. Desse modo, é possível recuperar em suas fotografias um relato, ou narrativa, que emerge da análise combinada entre imagens e legendas que engendram diferentes temporalidades (dias, meses, anos ou temporadas de viagens) referidas aos eventos familiares, ao período na escola, aos momentos de trabalho e de lazer.

Adicionalmente, a digitalização das fotos foi importante para vê-las melhor em função da predominância de formatos bem pequenos, entre $5 \times 6 \mathrm{~cm}$ e $6,5 \times 9,5 \mathrm{~cm}$, gerando um banco de imagens imprescindível em várias etapas do trabalho, especialmente na composição final do texto ${ }^{14}$.

O corpus, construído em função de procedimentos específicos, como indicado, está na base de uma série de problemas e indagações, que orientaram a interpretação do material: quem foi essa mulher e por que acumulou tantas fotografias de si mesma? Quem podia consumir fotografias entre os anos 1920 e 1960 na quantidade verificada? Quem poderia deslocar-se sendo mulher e solteira, nesse momento, por quarenta e seis

\footnotetext{
${ }^{13}$ Referindo-se ao período que vai de fins do século XIX até 1910, Boris Kossoy vai dizer: "Em função de tantas imagens que passaram a fazer parte do cotidiano familiar, surgiram álbuns especialmente desenhados, outro acessório da indústria da imagem que teve grande sucesso. Tanto as imagens pessoais (os retratos de família) como as industrializadas, que informavam e conformavam o imaginário popular, tinham de ser armazenadas, acondicionadas adequadamente. Os álbuns fotográficos se constituíram assim nos suportes da memória”. Kossoy (2002:46). Entretanto, como mostra Miriam Moreira Leite, a prática de organização da memória fotográfica por meio desse dispositivo ficou nesses anos restrita às camadas sociais mais ricas (1993:75).

${ }^{14}$ Escolhi diferenciar no texto figuras (imagens não fotográficas, embalagens para guardar fotos, desenhos) e fotos, o que implica em uma numeração diversa para um e outro tipo de imagem.
} 
lugares diferentes de passeios? O que esses registros biográficos poderiam informar sobre a sociedade do momento em que essa personagem viveu?

Tais questões serão desenvolvidas no trabalho, que está segmentado em três capítulos. No primeiro, apresento a personagem caracterizando-a em relação ao contexto social da cidade de São Paulo entre os anos 1920 e 1960. Organizo as fotografias cronologicamente, destacando temas como a imigração alemã urbana, os deslocamentos de passeios na cidade e nos arredores, como a Riviera Paulista e a Praia Azul na Represa Guarapiranga. Chamo a atenção para um circuito de trocas afetivas de retratos entre ela, parentes e amigos; evidencio um circuito de produção/consumo de fotografias por meio dos endereços de fotógrafos e lojas voltadas para a prática amadora no centro da cidade e ruas próximas. Esses dados normalmente estão impressos ou no verso das fotos, ou nas embalagens para guardar fotografias. Sua importância cresceu gradativamente, à medida que são materiais capazes de dar acesso à dinâmica do mercado visual no período.

No segundo capítulo, recupero a formação de uma cultura balneária litorânea, da qual a coleção se mostrou reveladora. A análise estrutura-se a partir da dicotomia lazer/trabalho, evidenciando como as relações profissionais para Cleonice lhe permitiram a criação de laços afetivos de sociabilidade e, portanto, motivaram os deslocamentos em busca de sol, mar e calor. Pelo arranjo que fiz é possível acompanhar o crescimento do turismo balneário a partir de 1927 (foto mais antiga do litoral) e sua posterior intensificação com o surgimento de uma rede de estabelecimentos e serviços hospitaleiros, criados para turistas que saíam da capital e do interior do estado. As fotografias foram feitas em um período intermediário entre dois momentos: o de elitização da orla da praia em fins do século XIX e sua gradativa popularização em razão da massificação do turismo, na segunda metade do século XX. As consequências dessa dinâmica no plano visual fotográfico é a captação ou de ambientes supostamente vazios, exclusivistas, ou da intensa movimentação de banhistas, especialmente a partir dos anos 50 .

No terceiro capítulo, mostro como três estâncias balneárias do interior de São Paulo foram destinos importantes nas deambulações de Cleonice. O ambiente campestre oferecia um clima ameno e agradável, além de paisagens e cenários diferentes da capital e do litoral. Águas de Lindoia, Serra Negra e Campos do Jordão surgem como espaços de lazer a partir da dicotomia curismo/turismo, práticas de cura de doenças e diversão, que definiram o destino destas localidades. Ao declínio gradativo da presença de 
doentes (curismo) a partir de meados dos anos 1940 corresponde a ascensão do turismo. As fotografias revelam fundamentalmente o aspecto turístico, para o caso das primeiras cidades visitadas em 1943, e alguns roteiros turísticos oficiais em Campos do Jordão, estabelecidos pela prefeitura desta cidade já na década de 50 .

Uma vez que esses materiais me chegaram pré-constrangidos, ou seja, usados, ao manipulá-los procuro retirá-los do silêncio próprio e natural da fotografia tomada isoladamente, reanimando-os, recombinando-os como um bricoleur (Lévi-Strauss 1970), procurando neles traços semelhantes para criar tipologias, bem como novos arranjos seriados a partir de padrões materiais, formais e temáticos. Estes arranjos foram produzidos tendo em vista as questões que animam o trabalho, todavia possibilitem outras interpretações. Faço esses arranjos, porém, como um detetive que segue rastros, pistas e indícios, elementos que, somados, permitiram montar séries e conjuntos tipológicos que possibilitaram reconstituir as histórias e narrativas que emergem da coleção (Ginzburg 1994).

Ao empreender uma análise da cultura visual fotográfica amadora privada, que emergiu entre os anos 1920-1960 o fiz distanciando-me de alguns estudos (há poucos ainda) sobre o amadorismo cineclubista (COSTA e SILVA, 2004), ou ainda (PEREIRA, 2010) que analisa a produção do advogado e fotógrafo amador Alberto de Sampaio (1870-1931). Foi possível notar que a cultura amadora fotográfica carece de mais pesquisas e, sobretudo a cultura amadora privada, tema que ainda não recebeu tratamento na literatura acadêmica brasileira nem pela História, Sociologia ou Antropologia. Esta última tem tido especial interesse na produção de imagens fixas ou em movimento, mas problematiza pouco a vida social enquanto imagem e visualidade. Não raro, a imagem torna-se uma ferramenta de apreensão e produção do real e resulta em documentários, ou etnografias visuais. Os materiais de arquivo e coleções são ainda pouco abordados. Não se pode, todavia, deixar de reconhecer a importância de publicações como os Cadernos de Antropologia e Imagem do Núcleo de Antropologia e Imagem (NAI), Oficina de Ensino e Pesquisa em Ciências Sociais, IFCH da UFRJ, organizado por Clarice Ehlers Peixoto e Patrícia Monte-Mór, e da publicação Antropologia \& Imagem vol. 1, (2011) organizada por Clarice Ehlers Peixoto. Neste volume são apresentados trabalhos na interseção entre imagem e família. No campo específico da fotografia de família, é comum a abordagem combinada entre análise das imagens a partir do seu cotejamento com relatos orais (CARVALHO 2011; BRUNO 2009; SILVA 2008; LEITE, 2003; VON SINSOM, 1998). A família foi um dos fatores 
de maior importância no desenvolvimento histórico da fotografia, pois seus desejos de ver representados seus laços afetivos promoveu avanços técnicos e o surgimento do mercado de retratos, como um segmento fundamental na indústria da imagem. Também a relação entre consumo de espaços turísticos e fotografia ainda não recebeu tratamento adequado. A fotografia, como notou Susan Sontag (2004) e John Urry (1999) dá uma forma à viagem, ao mesmo tempo que tirar fotos mitigaria o sentimento de desorientação próprios do deslocamento, do fato de se estar viajando. 


\title{
Capítulo 1: Cleonice Maria Heine em São Paulo: arquivar a si mesma e guardar a cidade
}

\author{
Uma história de vida não é feita para ser \\ arquivada ou guardada numa gaveta como \\ coisa, mas existe para transformar a cidade \\ onde ela floresceu. Ecléa Bosi (2003: 199)
}

A partir de um arranjo de 46 fotografias me proponho a contar a história de Cleonice na cidade de São Paulo, entre os anos 1920 e 1960. Observei que dois circuitos movimentam as fotografias - o circuito afetivo e o circuito comercial. Por conseguinte, organizo a narrativa em função dos espaços percorridos e experimentados pela personagem: a casa, a escola, o clube e a represa; os arredores e o centro da cidade de São Paulo. O circuito afetivo diz respeito às relações familiares que aparecem, sobretudo, no retrato de parentes e amigos acompanhados ou não por ela. O comercial liga-se às relações que Cleonice mantinha com o centro de São Paulo, lugar onde trabalhava e mandava revelar suas fotografias. Nestas, ela aparece na rua andando, faz pose com o grupo de amigos de trabalho na Avenida São João, comparece a importantes eventos coletivos como o IV Centenário da capital paulistana no Vale do Anhangabaú.

$\mathrm{Na}$ descrição dos espaços praticados e dos circuitos aos quais as fotografias se referem, a cidade figura não como cenário, mas como um personagem do relato, nem sempre fotografada, mas constantemente presente, como, por exemplo, nas embalagens para armazenamento de fotos e nos carimbos impressos no verso das imagens fotográficas, do qual se podem extrair dados como endereços de estabelecimentos comerciais e nomes de fotógrafos retratistas.

Os primeiros registros datados na coleção remontam ao ano de 1926 e sua legendagem é feita em alemão. Essas legendas configuram um importante indício da socialização de Cleonice entre membros da comunidade alemã, especialmente de São Paulo, por meio de sua tia, Lina Heine.

Comecemos pela imagem mais antiga do conjunto (foto 2), um retrato em formato carte cabinet que não possui informação de data e local, mas que por suas características materiais, deve ter sido produzido entre meados dos anos 1900 e fins dos anos 1910. Nele aparecem retratados os pais de Cleonice, o Sr. Germano Heine, 
imigrante alemão, e a Sra. Ida Heine, brasileira, segundo informação obtida no Arquivo da Cúria Metropolitana de São Paulo ${ }^{15}$. É possível que a foto tenha sido feita quando o casal ainda residia em Santa Catarina, de onde migraram para São Paulo, provavelmente no início da década de 1920, quando Cleonice era ainda criança.

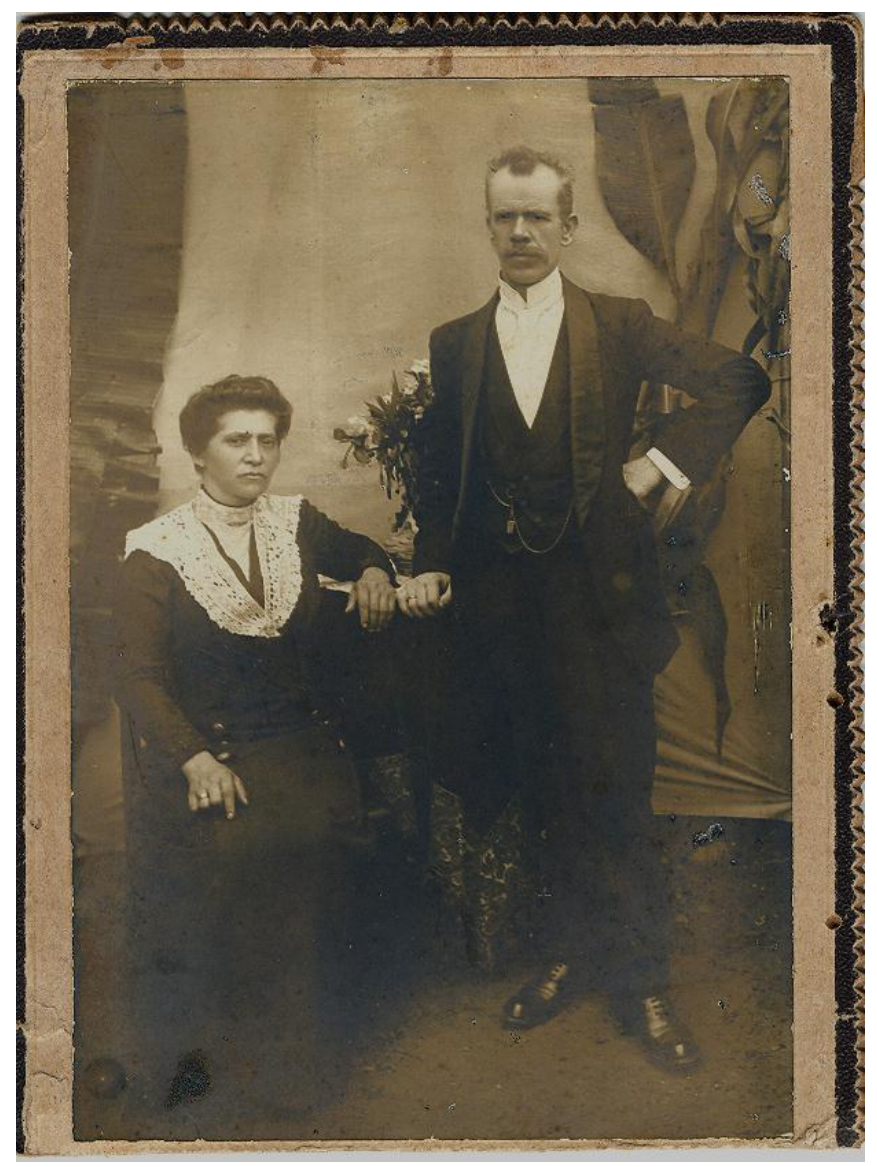

Foto 2: Retrato, formato carte cabinet S/D dos pais de Cleonice, Germano e Ida Heine. Dimensões: 14 x $10 \mathrm{~cm}$.

Observa-se, em primeiro lugar, o cenário montado atrás do casal: o tecido esticado e amarrado e, sobre este fundo, uma mesa sobre a qual apóiam, ela o braço e ele, a mão. As folhas de bananeira - de acordo com a convenção da época ${ }^{16}$ - evocam uma natureza tropical em sutil desacordo com as roupas escuras dos modelos. Ao contrário de muitas fotografias de casais, no período compreendido entre 1880 e 1910,

\footnotetext{
${ }^{15}$ Registro de Batizados da Igreja de São Judas Tadeu - Jabaquara 1960, p.83, n. 2707. 7-5-18-9. Armário 28 - n. 17. Agradeço ao Jair, funcionário do arquivo que foi, na única visita que fiz, muito solícito e paciente.

2 Após a invenção do formato carte de visite, cada década teve seu cenário específico: cadeiras e mesas de diferentes estilos; cortinas; balaustradas, pedestais etc. As palmeiras são um modismo na década de 1890 (KOSSOY, 2002: 39).
} 
aqui é a mulher quem está sentada, quando pode ter sido mais comum ver os homens sentados e as mulheres de pé ${ }^{17}$.

Diante dessa imagem, poderíamos perguntar: é possível conhecer a posição social dos pais de Cleonice neste retrato profissional de estúdio? Seriam eles realmente as pessoas que as roupas denotam ser, isto é, uma classe média urbana ainda em formação no país? Afinal, como indica Gilda de Mello e Souza, as classes sociais eram um fenômeno novo em fins do século XIX, e as roupas tornaram-se importantes elementos de distinção social, constituindo uma forma de marcar diferenças (SOUZA, 1987: 111-141). Baseado na análise desta imagem, mas também na relação que ela mantém com outras fotos que Cleonice herdou de seus parentes, creio tratar-se de uma família que se autorrepresenta como classe média. Quanto às vestimentas, lembremos que era comum até meados do século $\mathrm{XX}$ que os estúdios fotográficos mantivessem roupas para serem emprestadas aos clientes no momento de produção do retrato. Uma indicação de que uma roupa poderia não ser dos retratados é o quanto elas aparecem na foto desajustadas a seus corpos: muito grandes ou muito pequenas.

Já na foto 3, um grupo de pessoas é visto no interior de uma casa, em uma festa de Natal, indicada pela árvore decorada à direita. Nesta imagem, a senhora sentada de saia escura ao lado da mulher com bebê no colo é Dona Lina, única pessoa identificada, que reaparecerá em outras imagens na capital paulista, ou em Ubatuba, no litoral norte, em 1942. O homem na frente da árvore de Natal é seu marido ${ }^{18}$.

\footnotetext{
${ }^{17}$ Para uma discussão sobre os padrões de representação no formato carte cabinet cf. Carlos Eugenio Marcondes (1983).

${ }^{18}$ No dia em que fui entregar o texto de qualificação à professora Solange Lima, passei no antiquário Brasil Antigo para conversar com Dona Cecília. Novamente olhei o que havia de fotografias para vender e encontrei, no meio de várias fotos (entre as quais imagens que pertenceram à irmã do comediante Ary Toledo), um retrato de Lina e o marido. Visita feita em meados de julho de 2011.
} 


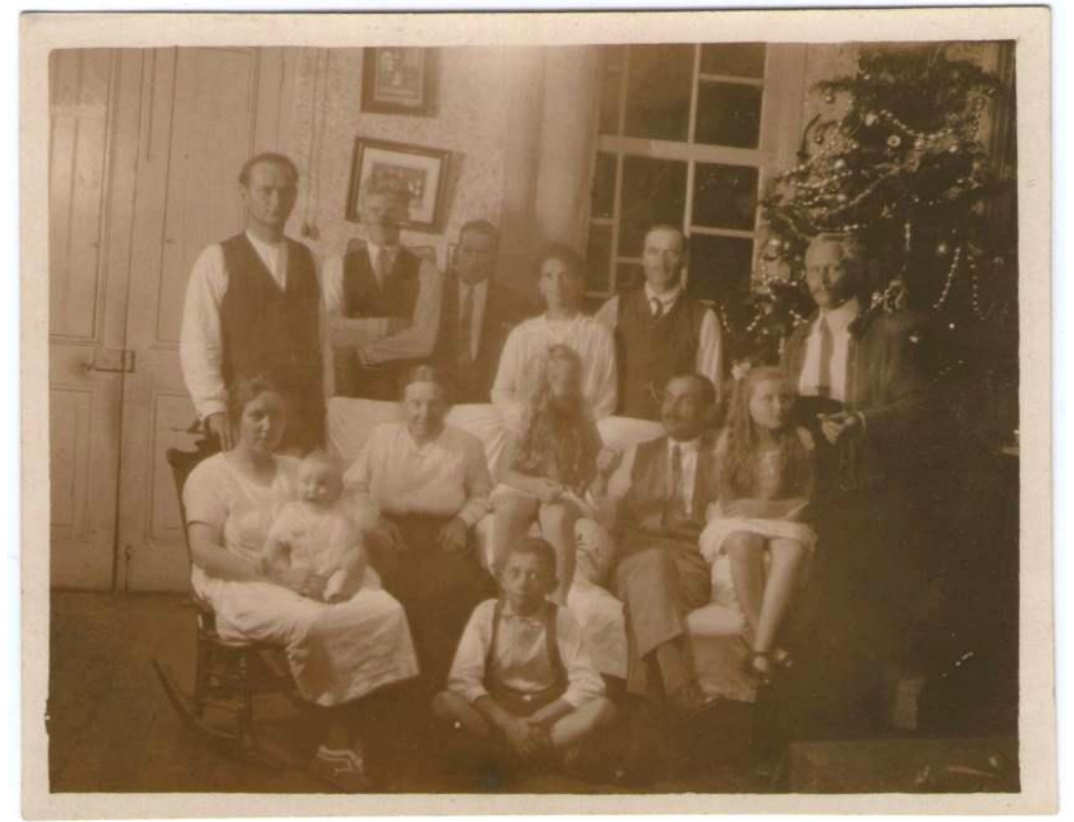

Foto 3: Grupo familiar no interior de uma casa, com destaque para Dona Lina, a senhora de saia escura. S/D. Dimensões: 10,5 x 8cm.

As duas imagens permitem lançar algumas hipóteses sobre o grupo familiar de Cleonice: o pai alemão (foto 2) deve ter morrido após esse retrato e a mãe brasileira veio para a capital paulista, tendo sido recebida por Lina Heine, tia de Cleonice (fotos 3 e 7). A migração definirá o destino da pequena família retratada na foto 4. A relação com essa tia teria possibilitado ainda a aproximação de Cleonice com a comunidade germânica de São Paulo, permitindo que ela e o irmão tivessem boa formação escolar, então elemento importante na sociedade paulistana em processo de urbanização.

As fotos 4, 5 e 6 foram feitas, ao que parece, por um fotógrafo conhecido e/ou pertencente ao grupo familiar de Cleonice. Ela e o irmão Germano estão bem vestidos e calçados, o que poderia indicar que estas roupas foram usadas com o objetivo de posar para o retrato. 


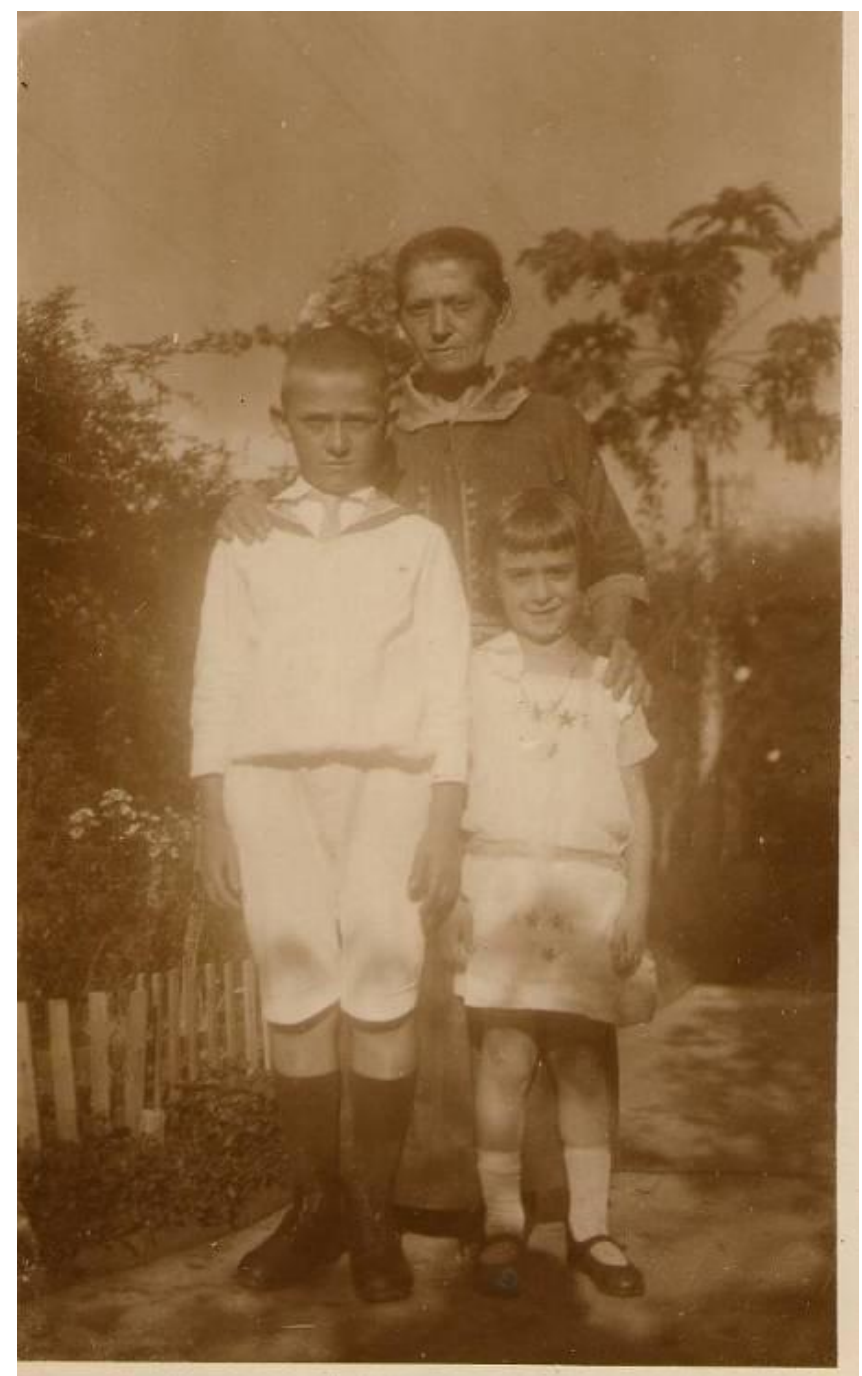

Foto 4: Dona Ida, Germano e Cleonice em retrato de 1927. A legenda "Andenken Von Tante Hanchen" (Lembrança da Tia Hanchen). Redução das dimensões originais: 12 x 7,5 cm. 

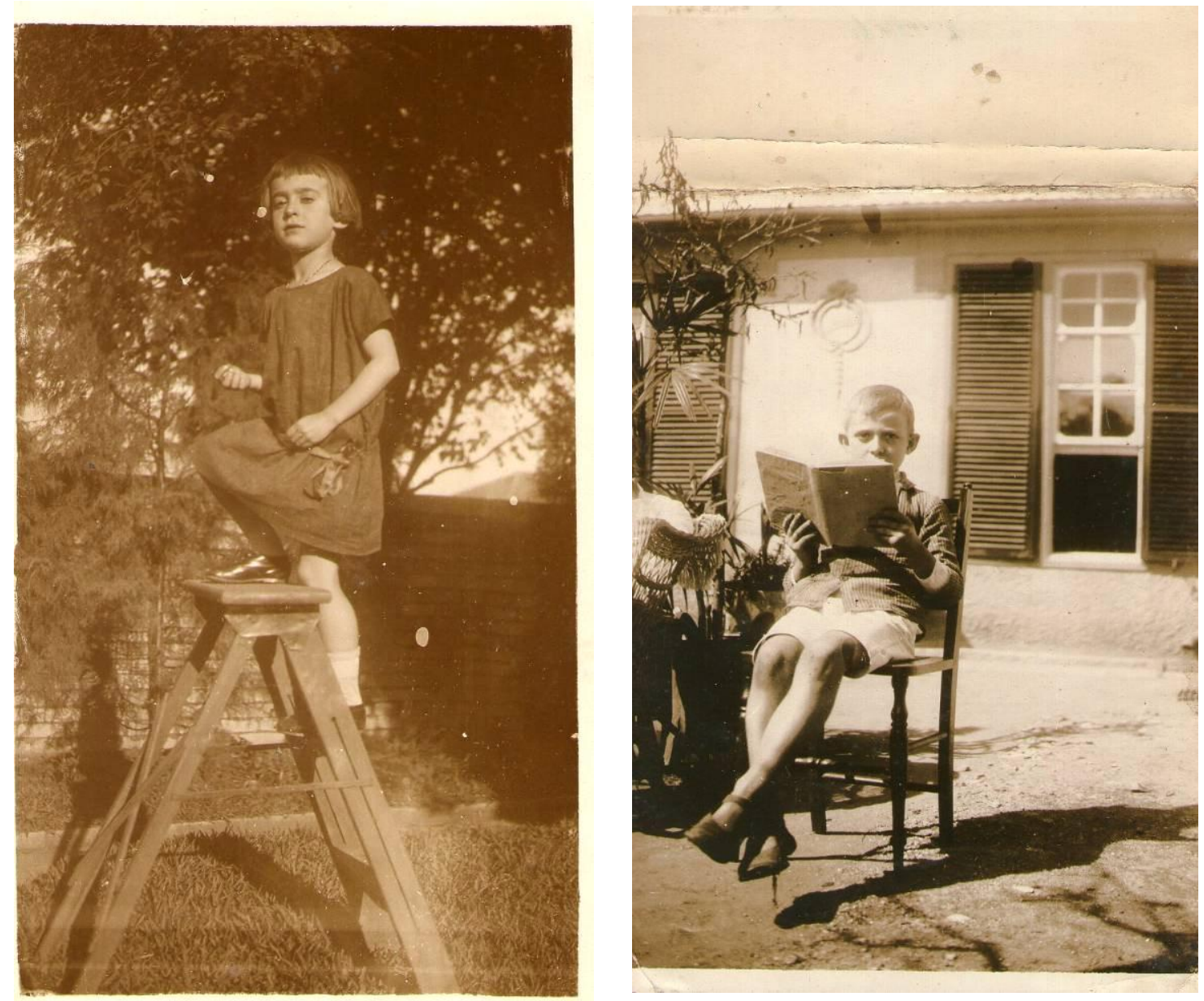

Fotos 5 e 6: Cleonice em 1927. Local não identificado. Germano, em 1924, na casa da Rua Artur de Azevedo, 30. Esta última imagem foi encontrada na coleção fotográfica de Germano. As fotografias captam representações da vida das crianças, como a recreação e o conhecimento escolarizado. Dimensões: 12 x 7,5 cm.

Esse grupo de imagens ensinam sobre quem são os Heine e, mais especificamente, quem é Cleonice. Ao chegarem a São Paulo, eles devem ter morado na casa da Rua Artur de Azevedo № 30. Esta hipótese baseia-se na descoberta de um retrato de Germano, irmão de Cleonice, no quintal de uma casa neste endereço ${ }^{19}$ (foto $6)$.

Em meados dos anos 1920, o antigo bairro de Pinheiros era considerado um "bairro caipira”, segundo afirmação de Regina Célia Bega dos Santos (1996: 57). Ele viria a expandir-se a partir dos anos 1930 e na metade de 1940. Lá moravam apenas 76 famílias, indica Antonio Barreto do Amaral (1969: 80-84). É interessante esclarecer o que o adjetivo "caipira" queria dizer no contexto social da época. Se o termo referia-se à "rural”, a definição do geógrafo Jurgen Von Langenbuch pode ser útil, quando afirma que rural corresponde às "extensões territoriais caracterizadas pelo conjunto de

\footnotetext{
${ }^{19}$ O número 30 desta rua não existe mais. A casa ficava bem próxima do atual Hospital das Clínicas.
} 
atividades, estabelecimentos, empreendimentos, 'usos do solo' e paisagens normalmente não encerrados no interior de cidades, mesmo que a ela estreitamente vinculados" (LANGENBUCH, 1971: 61).

As diferenças entre rural e urbano não eram ainda muito marcadas na São Paulo dos anos 1920, nem mesmo no centro da cidade. Naquele momento, a cidade paulistana possuía "70\% de edifícios térreos", e ainda era iluminada por "românticos lampiões à gás", mais da metade de seus veículos urbanos era constituída por carros movidos por "tração animal" (AZEVEDO 1961: 43). De fato, a cidade não ia muito além da área central, que ia se conformando como importante "eixo da rede de comunicações", centralizando bens e serviços, entre os quais, a produção e o consumo de fotografias de família.

A avidez do consumo de imagens fixas cresce proporcionalmente à evolução tecnológica dos equipamentos de captação, aos processos de revelação e à diversidade de suportes de papel. A família torna-se um dos temas mais recorrentes de produção visual. Este desenvolvimento da fotografia está ligado à sofisticação do comércio e aos serviços urbanos, a imagem fotográfica constituindo uma das mercadorias em circulação ${ }^{20}$.

A partir daí os retratos, em diferentes técnicas e formatos, se tornarão a forma expressiva da representação social dos laços familiares. Eles oferecerão ainda a maior fonte de renda para os fotógrafos em razão de suas qualidades comerciais tornando-se o "ganha-pão" destes profissionais (CARVALHO \& LIMA, 1994: 256). Tal afirmação pode ser estendida a toda a história da fotografia que, com a invenção de novos processos de captação e impressão, foi gradativamente barateando o custo para o consumidor final, que, no período coberto pela pesquisa, ainda são fundamentalmente os setores de elite e as camadas médias urbanas. $\mathrm{O}$ aumento do consumo de fotografias representa, portanto, um sintoma da expansão do acesso à câmara fotográfica que já vinha crescendo desde as primeiras décadas do século XX. Como afirma Olga Von Sinsom:

$\mathrm{Na}$ verdade, desde os anos trinta e quarenta com a 'democratização' do registro fotográfico mediante o surgimento de máquinas fotográficas de operação muito simples e relativamente baratas, que permitiram a fixação rápida e fácil de 'instantâneos', a vida dos grupos sociais e dos indivíduos

\footnotetext{
20 “Ganha-pão dos estúdios fotográficos, a fotografia nasceu para ser comercializada. A velocidade de suas conquistas tecnológicas se deve em muito a uma demanda social por formas mais econômicas e precisas de autorrepresentação". CARVALHO \& ALENCAR (2010: 127).
} 
passou a ser registrada muito mais pela imagem do que pelos livros de memórias, cartas ou diários, e a memória individual e familiar passou a ser construída tendo por base o suporte imagético (1998: 8).

Essa difusão permitiu a constituição de uma "cultura visual”, isto é, de um conjunto de hábitos, modos e disposições historicamente construídos que modificam a percepção visual e a experiência social de uma época. Reunidos, esses motivos parecem explicar o grande volume de fotos encontradas na coleção CMH. Não se deve esquecer que ela desde muito criança passou por uma socialização fotográfica, o que pode tê-la disposto a gostar de ser fotografada e, quando teve condições financeiras para fazê-lo, não titubeou em investir dinheiro nessa forma de consumo, sociabilidade e autorrepresentação.

Pelas imagens que aparecem de sua família, o gosto pelo retrato familiar era algo partilhado. O processo de estabelecimento da família Heine em São Paulo, com o auxílio dos parentes, possibilitou que ela e a seu irmão estudassem na Escola Alemã da Vila Mariana. Mais tarde, o primeiro emprego de Cleonice seria justamente em uma firma cujo proprietário era o alemão Jhon Jürgen. Pode ser que ela tenha conhecido pessoas das diferentes colônias alemãs à medida que circulava pela capital e pelo litoral, em lugares onde esses imigrantes marcavam presença histórica: Santo Amaro, Santos, São Vicente, Itanhaém e Ubatuba. É possível também que a tia Lina Heine, em algum momento, tenha ido viver em Ubatuba, indo Cleonice visitá-la. Com relação à escolha dos outros lugares visitados, o que parece atraí-la é o turismo associado às paisagens naturais.

Recuperar informações relativas à presença alemã na sociedade paulistana daqueles anos é fundamental, pois os lugares nos quais Cleonice esteve, receberam, imigrantes e/ou descendentes de germânicos. Não quero dizer com isso que ela ia a esses lugares para encontrar membros da comunidade, mas o fato de estar em ambientes que tinham essas características (sobretudo no litoral) é importante para compreender como alguns grupos estrangeiros estão na gênese do gosto recreativo pelo litoral e pelo campo.

A primeira leva de imigrantes alemães chega ao estado de São Paulo entre 1827 e 1828 e, em 1829, estabelecem-se colônias em Itapecerica da Serra e Santo Amaro; nos arredores da capital (em Santos, São Vicente); em Ubatuba (no litoral Norte) e no interior do estado (em Sorocaba, Ipanema e Itapetininga). A presença de tia Lina na vida 
dos Heine parece reforçar os laços afetivos com um grupo de alemães urbanos, ligados ao centro da cidade.

O alto custo de vida na São Paulo de meados da década de 1920 e os contrastes extremos entre pobres e ricos levavam muitos dos imigrantes a viverem nas imediações próximas ao centro, em áreas de alagamento (BESSE 1999 e SEVCENKO 1992). Creio que se os Heine não tivessem recebido o apoio de Lina teriam perdido o contato com a comunidade alemã e sucumbido às difíceis condições da vida na capital paulista. Nesse sentido, os tios foram vitais na vida de Ida, Cleonice e Germano.

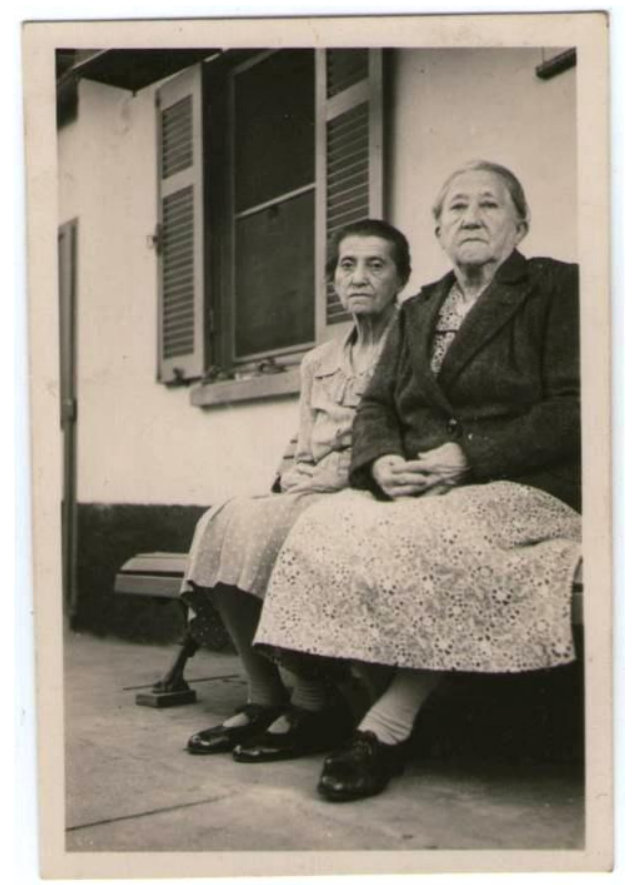

Foto 7: Retrato S/D de Dona Ida e Tia Lina em lugar não identificado. Coleção GH. Dimensões: 6 x 9cm.

A foto 8 mostra o tio de Cleonice. Ao considerar sua roupa e o fundo sob o qual foi fotografado, podem-se vislumbrar indícios da posição social que ele e Lina possuíam.

O casal pertencia às classes médias urbanas em expansão; o avental branco que ele porta sugere que fosse um dos vários técnicos especialistas do setor químico que vinham ao Brasil ensinar, dar assistência ou empreender o desenvolvimento da indústria química no País, especialmente em São Paulo. A evolução desse ramo industrial está atrelada à expansão da indústria da fotografia, como sabemos. Lembra Roland Barthes que a câmara obscura dos pintores não é mais que uma das causas da fotografia; o essencial talvez tenha sido a descoberta da química (1984: 52). 
Observando mais atentamente a foto n. 8, vemos que, atrás da figura masculina de avental branco, há várias informações escritas, ainda que cortadas, que parecem denotar ser ele talvez um profissional da ampla área da produção e comercialização da fotografia. Podem-se entrever termos como "amador" "ampliação" "artigos" e finalmente "photo" e, pela postura do modelo, não é impossível que seja ele o empreendedor alemão na frente do seu estabelecimento no centro da cidade.

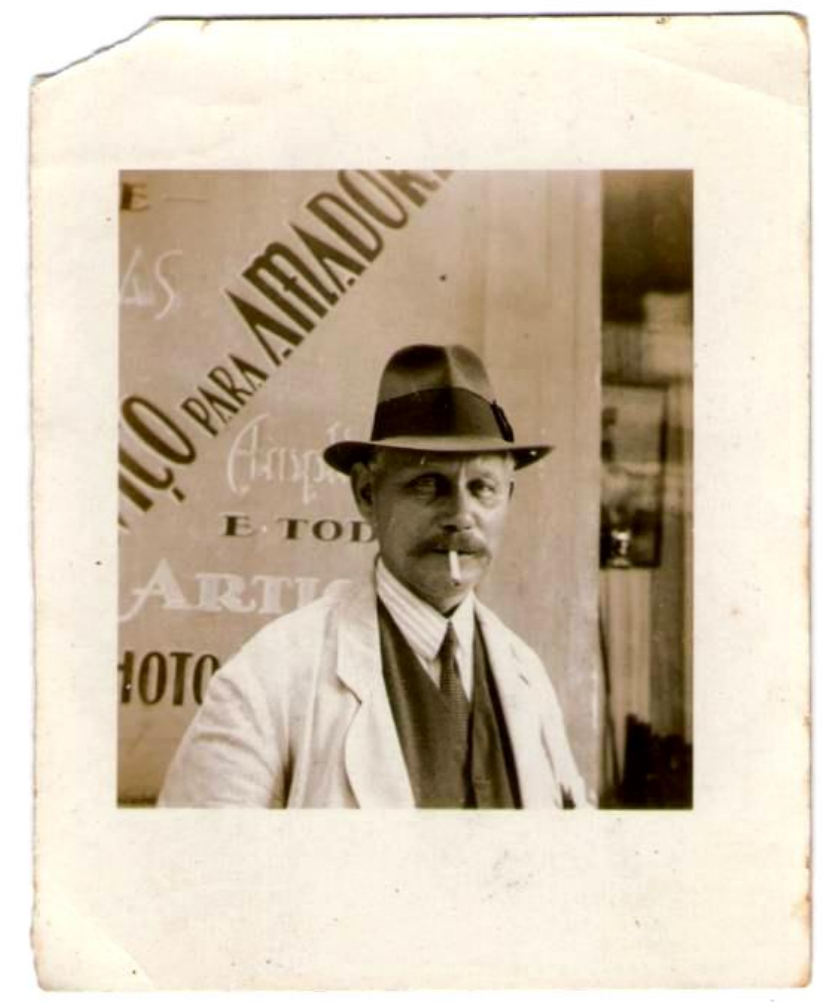

Foto 8: O anônimo marido de Dona Lina, tio das crianças Heine, em foto encontrada na coleção Germano Heine. Este personagem aparece algumas vezes principalmente na coleção do irmão de Cleonice. Dimensões: 7 x $9 \mathrm{~cm}$.

Alguns grupos alemães se estabelecem na região central já na segunda metade do século XIX. Nas palavras de Evanice Maria Högler Ribeiro:

Na cidade de São Paulo, no decorrer da segunda metade do século XIX, a colônia alemã cresceu muito. Por volta de 1875 , já era constituída por 2.000 pessoas e, em 1890, por 2.500, sendo o total da população da cidade de São Paulo de, aproximadamente, 50.000 habitantes (2002: 146).

Entre 1920 e 1940, especialmente, são muitos os alemães a imigrarem para o Brasil, em um momento no qual a Alemanha, então República de Weimar, se encontrava 
em profunda crise econômica. O adensamento dessa população de estrangeiros se fará nas áreas urbanas do País, e a capital de São Paulo destaca-se como um "polo migratório" (DIETRICH 2007: 207). Nicolau Sevcenko, ao descrever a São Paulo na passagem do ano de 1919 para 1920, aponta a população que sucumbia às dramáticas enchentes ao redor da área de confluência entre os rios Tamanduateí e Tietê e mostra que, nessa população, estavam estrangeiros como espanhóis, árabes, israelitas e alemães (SEVCENCKO, 1992: 30).

Cleonice chega à capital paulista nesse contexto e, pelo que mostram suas imagens de infância, não fazia parte da população de imigrantes pobres, inclusive alemães, morando nas áreas não urbanizadas da capital paulista. Os seus retratos, dos primeiros tempos de infância até a juventude e o modo como eles circulam - como dádivas e presentes - permitem recuperar o seu pertencimento à comunidade teutobrasileira de São Paulo e de Santa Catarina.

Mas que outros parentes aparecem nas fotos? A prima Laís - sobre a qual não há nenhuma outra informação a não ser seu primeiro nome escrito nestes dois retratos abaixo, um enviado a Dona Ida (foto 9) e o outro a Cleonice (foto 10) - é uma delas.
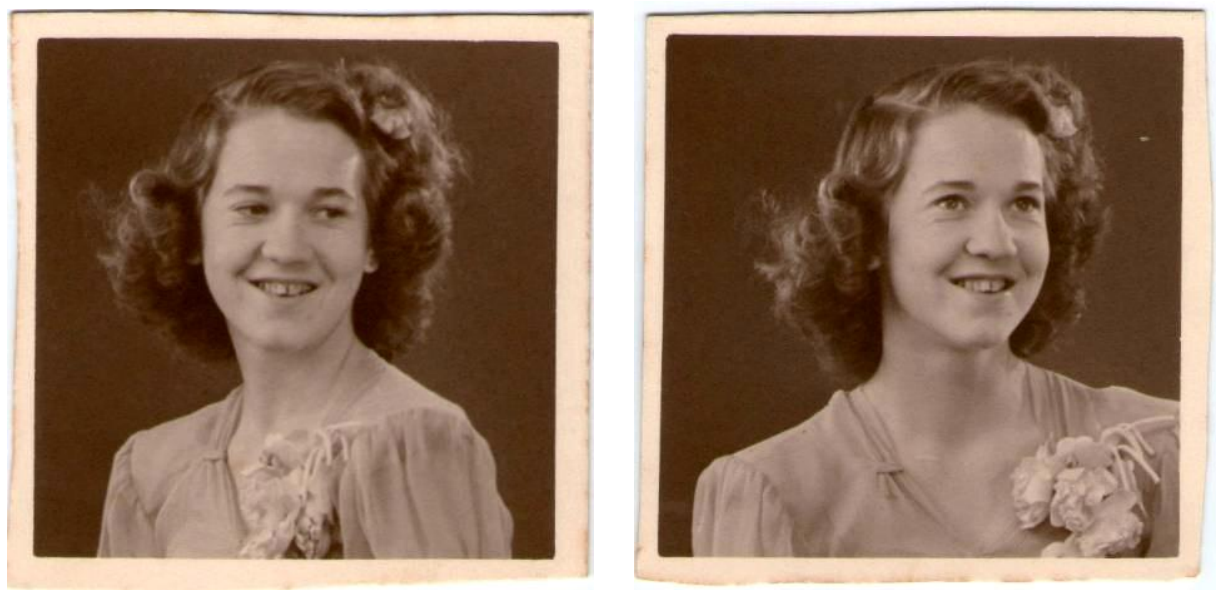

Foto 9: Laís em retrato enviado a Dona Ida acompanhado da dedicatória: "Á estimada titia Ida, ofereço-lhe com afeição". Foto: 10 "Ofereço-te querida prima como prova de minha estima”. Dois retratos da prima Laís, S/D. Dimensões: 5,5 x $5,5 \mathrm{~cm}$.

É possível observar nos dois retratos que a prima não olha para a câmara, mas sorri em ambos; na primeira tomada, seu olhar é dissimulado (para seu lado esquerdo e um pouco para baixo), no segundo, ela levanta os olhos, o que faz com que, vistas lado a lado, as imagens ganhem um movimento sequencial. As diferentes expressões do rosto 
seguramente tiveram origem na orientação dada pelo fotógrafo considerando que as imagens foram produzidas para servirem de presentes a parentes e/ou amigos. A diferença entre as poses poderia sublinhar as diferentes destinatárias.

Em 1960, Cleonice recebe um cartão postal dessa mesma prima por ocasião da passagem do ano. Informa a legenda, que intercala a escrita pessoal de Laís ao texto impresso: “À Srta. Cleonice Heine”, escrita à caneta, Boas Festas e Feliz Ano Novo impresso no cartão, "da prima Laís” ( também à caneta). Nesse momento, Laís morava em Brusque - Santa Catarina, que deve ser a cidade natal de Cleonice. A imagem do cartão postal, embora não exibida aqui, é significativa, pois mostra o aspecto arquitetônico externo e interno da Igreja Evangélica de Brusque. Lembremos que, em 9 de agosto de 1960, essa igreja inaugurava o órgão alemão BOHN, por ocasião do centenário da cidade de Brusque, conforme informações extraídas desse cartão postal. Essa informação é importante para levantar uma hipótese sobre o batismo e a primeira comunhão de Cleonice, realizado na igreja católica apenas em 27 de junho de 1960 (foto 10). Ela seria, até então, protestante como Laís? Os Heine eram protestantes? Não é possível saber, pois faltam indícios na coleção que permitam fazer essa afirmação.

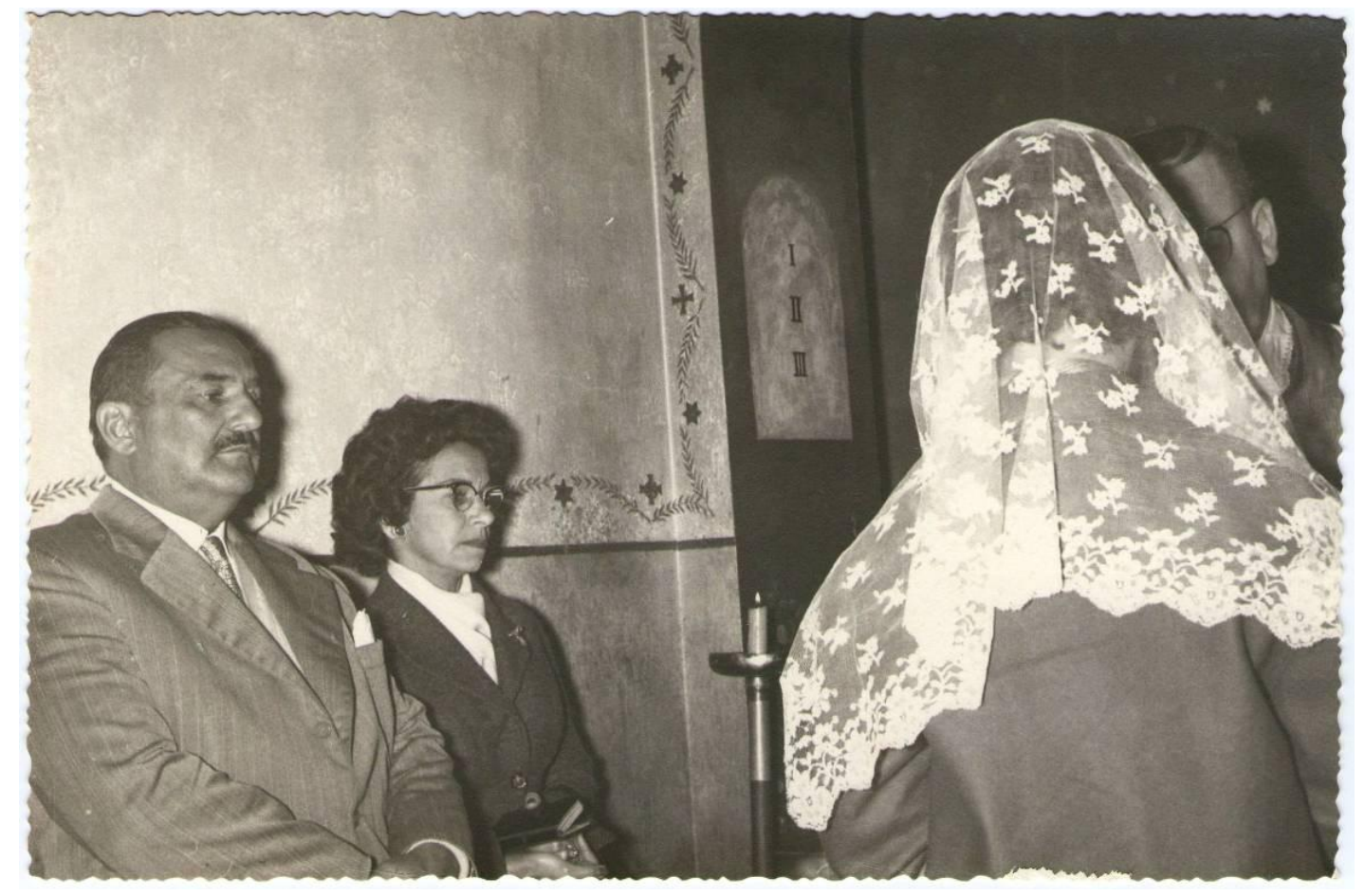

Foto 10: Batismo e Primeira Comunhão de Cleonice Maria Heine. 27 de junho de 1960. Redução das dimensões originais $11,5 \times 17 \mathrm{~cm}$. 
A presença de retratos de outros primos que moravam em Brusque revela ainda que, neste circuito afetivo, cabia à fotografia a tarefa histórica de manter vivo o elo com parentes distantes. Os retratos abaixo mostram quatro de seus primos em imagens padronizadas: paredes pintadas ao fundo; uso das cadeiras como apoio para as mãos uma constante na produção dos carte de visite e carte cabinet e que permanece como importante elemento cenográfico no século XX, continuando a fornecer padrões, mesmo depois da invenção da fotografia instantânea. Seria mesmo necessário apoiar-se a uma cadeira, ou o que ocorre aqui é a tentativa de evocar o ambiente já clássico dos velhos retratos do século anterior ${ }^{21}$ A regularidade das posições, como a mão direita apoiada ao espaldar, é delicadamente quebrada pela leve inclinação corporal dos protagonistas das fotos 11, 12,13 e 14. O primo Hans Meyer apoia-se na mesma cadeira que a prima Ulta. Eles se casariam no ano seguinte (foto 15).
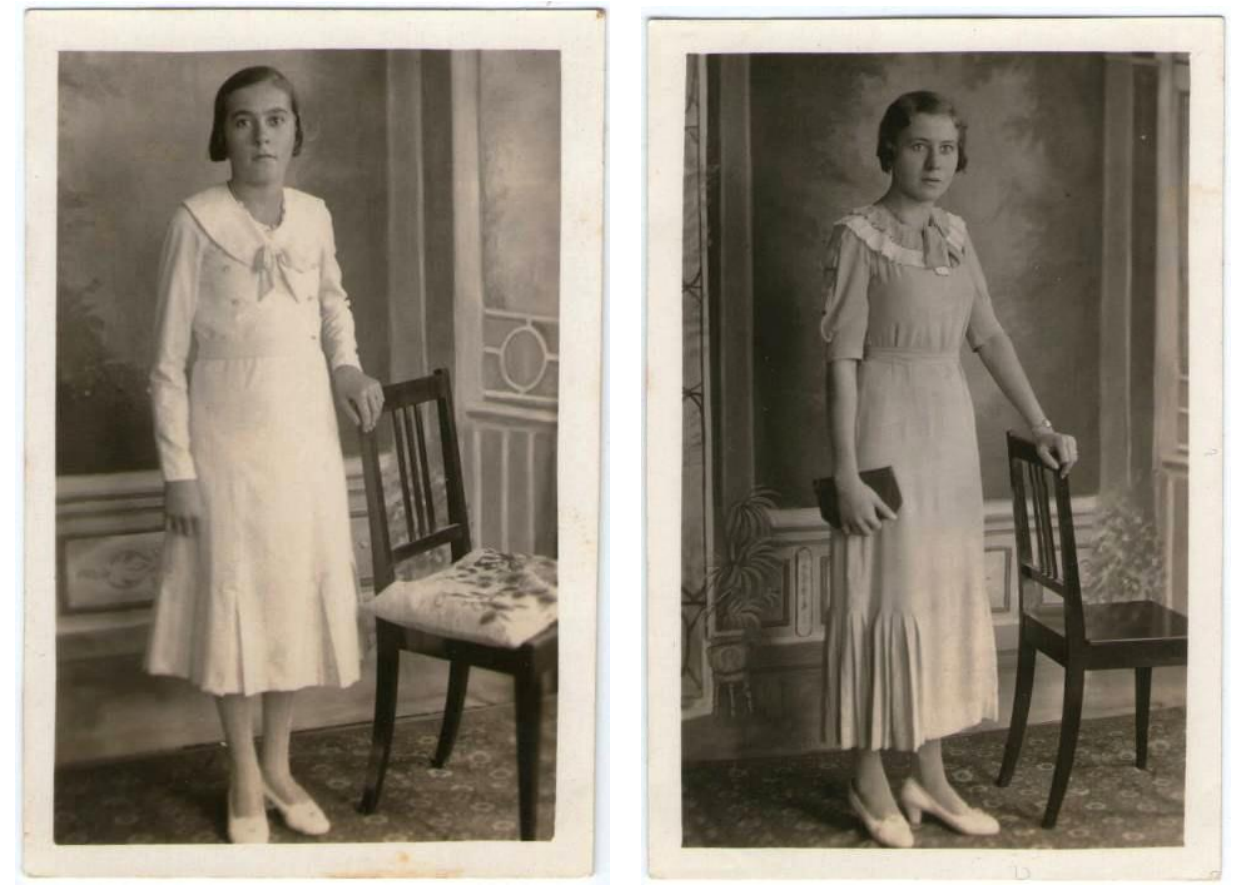

\footnotetext{
${ }^{21}$ Antonino, protagonista de um conto de Ítalo Calvino chamado a "Aventura de um fotógrafo", mostra como o interesse pela pose, contra a banalidade do instantâneo, o levou à "conclusão de que era preciso voltar às personagens em pose, com atitudes representativas de sua situação social e de seu caráter, como no século XIX”. CALVINO (1992: 56). Agradeço ao Edson Alencar a sugestão de leitura.
} 

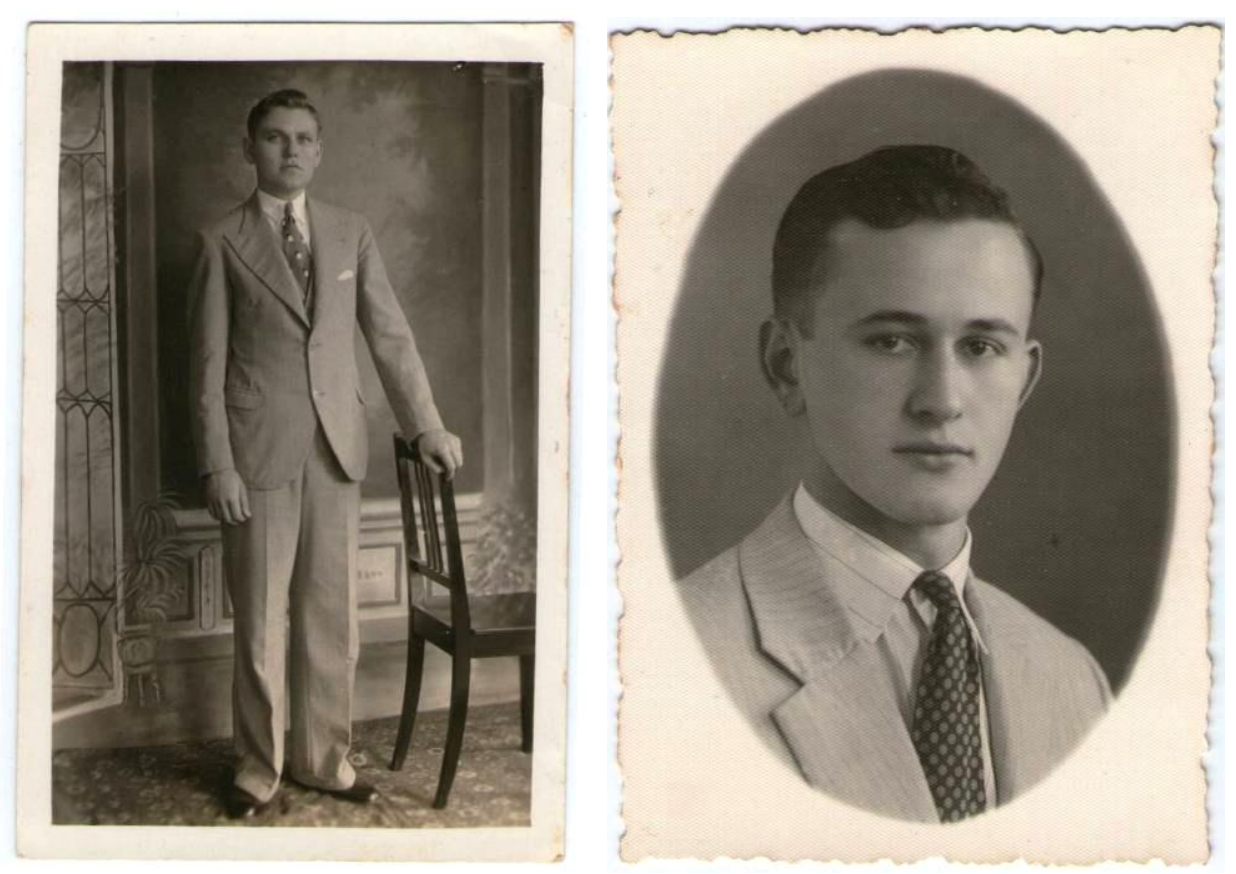

Fotos: 11, 12, 13 e 14: Os primos da esquerda para a direita: Lili Müller em 7-11-35, Olga em 10-11-35. Abaixo Hans Meyer em 7-11-35 e Ubaldo Müller s/d Foto Brasil, Brusque. Dimensões: 6x 8,5 cm.

O universo dos parentes de Cleonice foi emergindo com o trabalho de organização sistemática do material, pela recuperação de datas e nomes. Ao inseri-los em sequências cronológicas, evidencia-se um circuito de fruição afetiva das fotografias, restrito ao consumo familiar. Por exemplo, em 18 de julho de 1936, os primos Ulta e Hans Meyer se casam em Brusque e, se os Heine não puderam estar presentes ao casamento, a fotografia testemunhou o matrimônio. Silvye, outra prima, envia um retrato seu de perfil (que não mostro aqui) com a dedicatória: “À Cleonice, com amizade, aceite esta pequena recordação de sua prima Silvye. Brusque, 14-1-1945”.

Já o verso do retrato de casamento (foto 15) indica também o estúdio fotográfico onde foi feita a imagem: Foto Brasil, Brusque, o mesmo estúdio que realizara o retrato do primo Ubaldo Müller. A grafia do nome de Cleonice transforma-se, ora com dois L's, ou com Y. Mais para o idioma alemão ou mais para o brasileiro? A grafia cambiante pode apontar para o contexto cultural e político entre os anos 1930 e 1940, no qual o surgimento de tensões com a presença de germânicos ou seus descendentes, especialmente nas grandes cidades, foi marcada pela valorização dos símbolos nacionais brasileiros como a língua, por exemplo. 


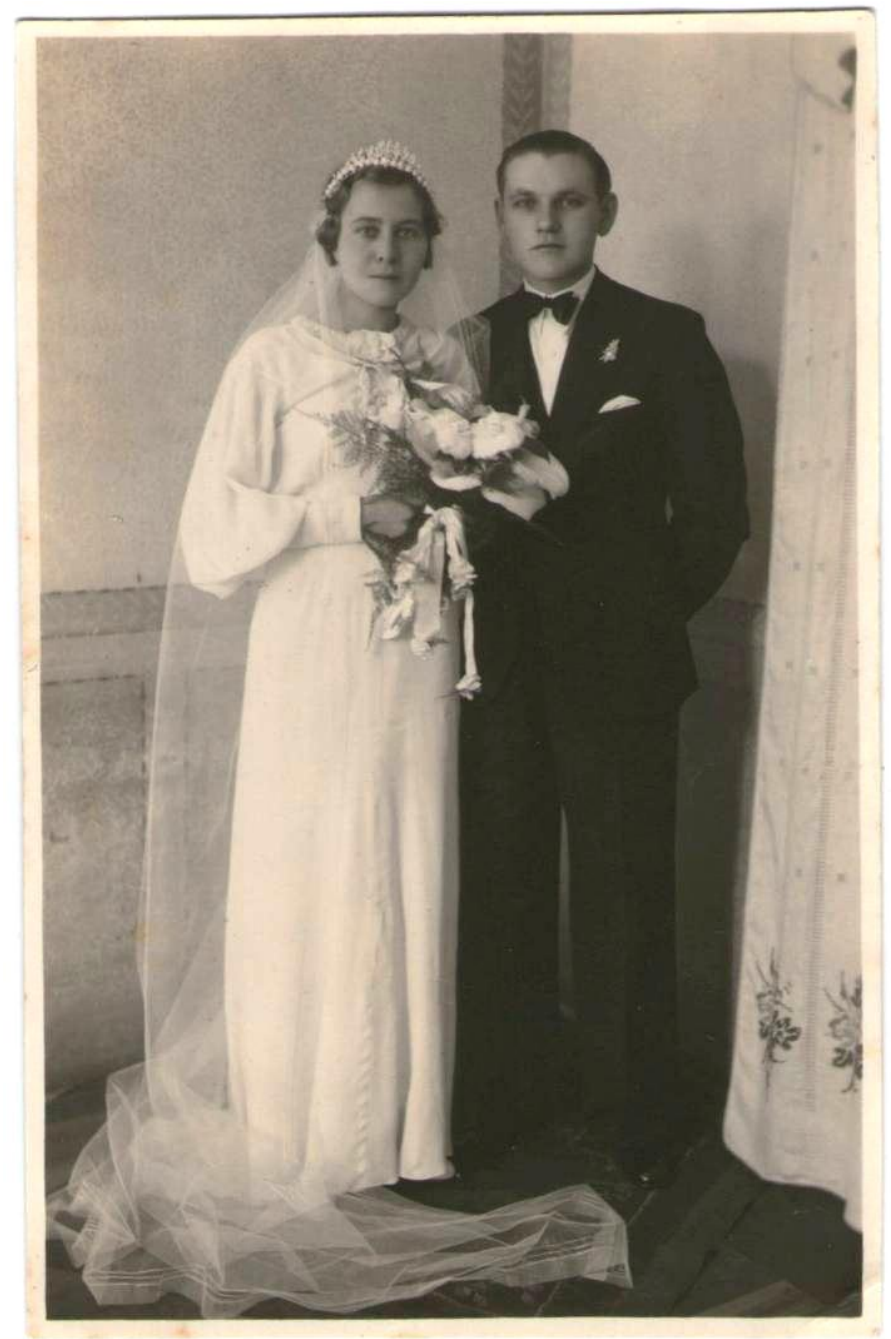

Foto 15: Os primos Ulta e Hans Meyer no dia de seu casamento. Brusque, 18 de julho de 1936.

Embora Laís, já nos anos 1930, escreva em português, essa prática só se torna comum na coleção CMH a partir de 1940, o que se mostra significativo, pois a data demarca o início da perseguição do governo Getúlio Vargas a membros e supostos membros do partido nazista em São Paulo. O fato de Silvye escrever em português, no fim da Segunda Guerra Mundial, pode ser uma indicação desta nova relação que o governo brasileiro estabeleceu com as comunidades teuto-brasileiras forçando-as a se integrarem à nação e rechaçando suas particularidades étnico-identitárias. Nesse contexto, muitos alemães e seus descendentes ganham o estigma de antinacionalistas. (PINTO 2009; DIETRICH, 2007). 


\subsection{Recreação, escola alemã e carnaval}

Entre 1920 e 1940, algumas das imagens foram identificadas com legendas em alemão, indicando que Cleonice compreendia o que ali estava escrito. Este é o caso, por exemplo, das fotografias feitas em um passeio à Freguesia do Ó, em 1929, ao sítio de Dona Therezinha (Dar Mitt Dona Therezinha) ${ }^{22}$ (fotos 16 e 17). Se com relação à presença alemã nesta região da cidade não foi encontrada nenhuma referência precisa, é possível dizer que a Freguesia do Ó era uma zona bastante procurada por quem buscava lazer e descanso próximo à capital ${ }^{23}$. Antes de trazer mais informações sobre essa região e sua função para a cidade, vale a pena notar o quanto a foto 16 e seu enquadramento são adequados ao motivo fotografado, isto é, o grupo. A coletividade reunida colocava certas dificuldades aos fotógrafos amadores, indica Charles Bourée, quando recomenda em seu Manual Prático ao Alcance de Todos:

Se o grupo for numeroso maiores serão as dificuldades. O operador após ter disposto as pessoas, escolhido bem o local, visão de conjunto, etc., terá que afastar-se um pouco do local de forma que os extremos do grupo nunca atinjam os bordos da chapa que se vá empregar, ficando, no entanto, deles afastados de cada lado cerca de dois a três centímetros. (1952: 30,31)

\footnotetext{
${ }^{22}$ Agradeço a Tiago Svoboda e Adriano Rotero as traduções de algumas legendas.

${ }^{23}$ Para uma história panorâmica deste bairro, ver BARRO (1977).
} 


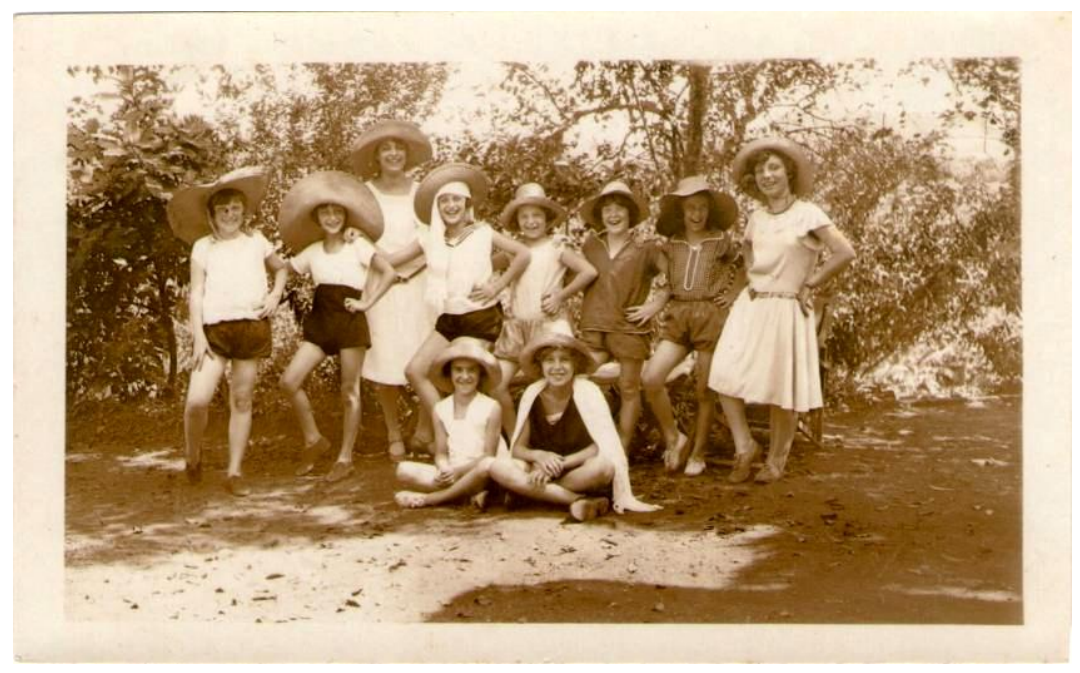

Foto 16: Cleonice, então com 10 anos de idade, sentada em primeiro plano à esquerda no sítio de Dona Therezinha em Freguesia do Ó. Dimensões: 11 x $7 \mathrm{~cm}$.

Se esta recomendação de Bourée ajuda a explicar a composição equilibrada da (foto 16) a foto 17 , ao contrário, guarda uma espontaneidade que foge a convenções. $\mathrm{O}$ fotógrafo valoriza a amplidão do espaço visto em perspectiva; Cleonice destaca-se com absoluta nitidez entre as meninas à frente e a figura borrada do rapaz que se moveu, estruturando a cena. Nesta imagem, podem estar misturados os trabalhadores do sítio e seus proprietários, que talvez estejam no fundo, em último plano (detalhe 17a). A menina em primeiro plano, desfocada, a segunda e alguns dos homens, logo atrás de Cleonice, parecem ser colonos do sítio.

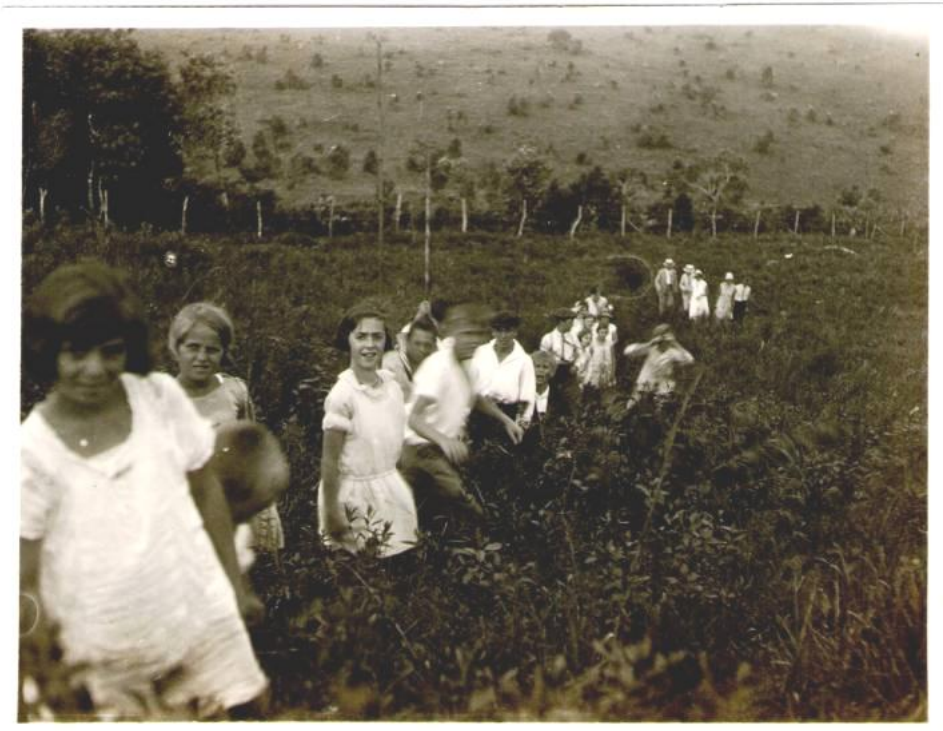

Foto 17: Cleonice em foto no sítio de Dona Therezinha na Freguesia do Ó. Redução das dimensões originais: 11 x 8, 5 cm. 


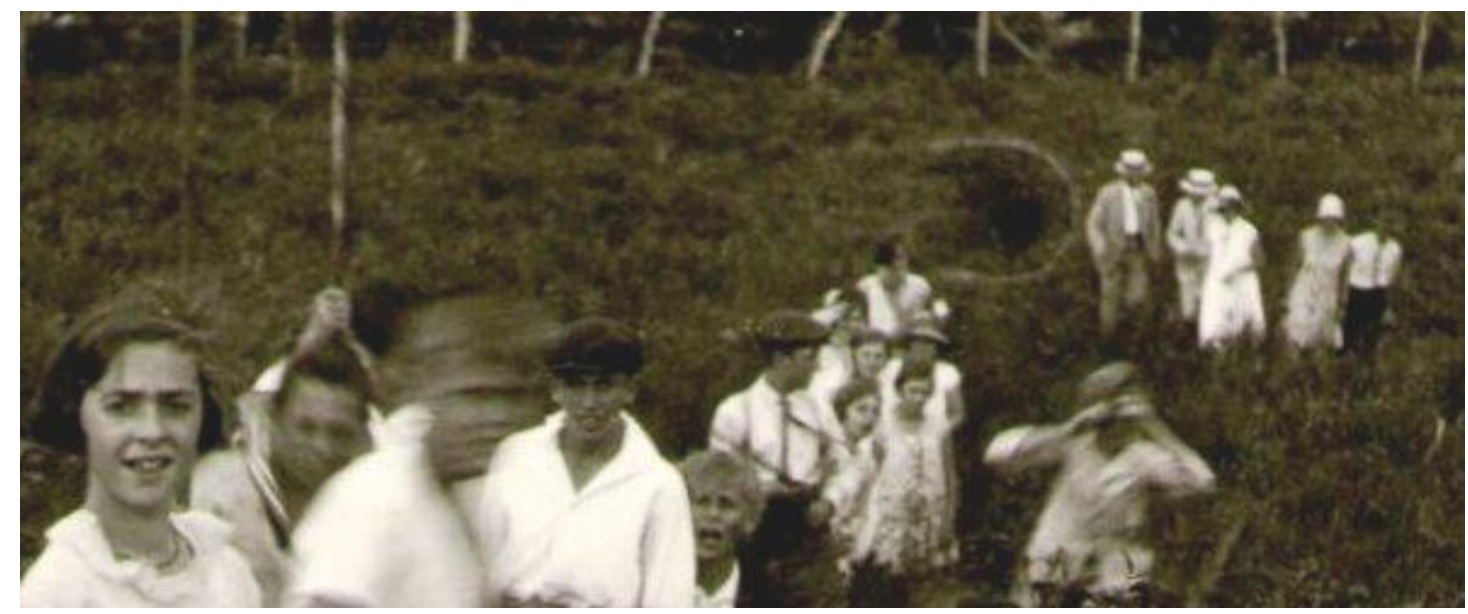

Detalhe 17 a: Cleonice, em primeiro plano, e os possíveis donos da propriedade ao fundo.

Lembremos que os sítios tinham funções úteis em relação à cidade, assim que essas terras podem ter sido adquiridas a partir da especulação imobiliária, que cria loteamentos nos arredores da cidade desde os anos 1920. Segundo Jurgen Von Langenbuch, tais áreas tinham três funções importantes para a capital: I - Equipamento hidrelétrico e hidráulico da cidade; II - Recreação campestre dos paulistanos; III Agricultura comercial de abastecimento urbano. Os três aspectos estão, segundo o autor, vinculados à vida experimentada na cidade e ao desenvolvimento econômico e cultural do período (1971: 161). Eles permitem entender o contexto no qual essas fotografias foram produzidas e também o tipo de passeio disponível nos arredores que atraíam os citadinos. Nesse sentido, as duas imagens podem ter sido tomadas em um fim de semana, ou no período das férias escolares, ou mesmo em um feriado.

Cinco anos depois, em 1934, Cleonice aparece posicionada exatamente no meio de um grupo de seis jovens, no qual Germano, seu irmão, deve ser o fotógrafo, em um passeio a Parada de Taipas próximo ao Pico do Jaraguá (foto 18 e detalhe18a). Parte do solo, sobre o qual está deitado o grupo, organiza o primeiro plano sugerindo que o fotógrafo também se deitou colocando-se com a câmara, um pouco abaixo dos modelos. Nessa fotografia Cleonice é personagem secundária e a cena na se estrutura em torno dela, ao contrário do que ocorre em várias outras fotos em que está presente. 


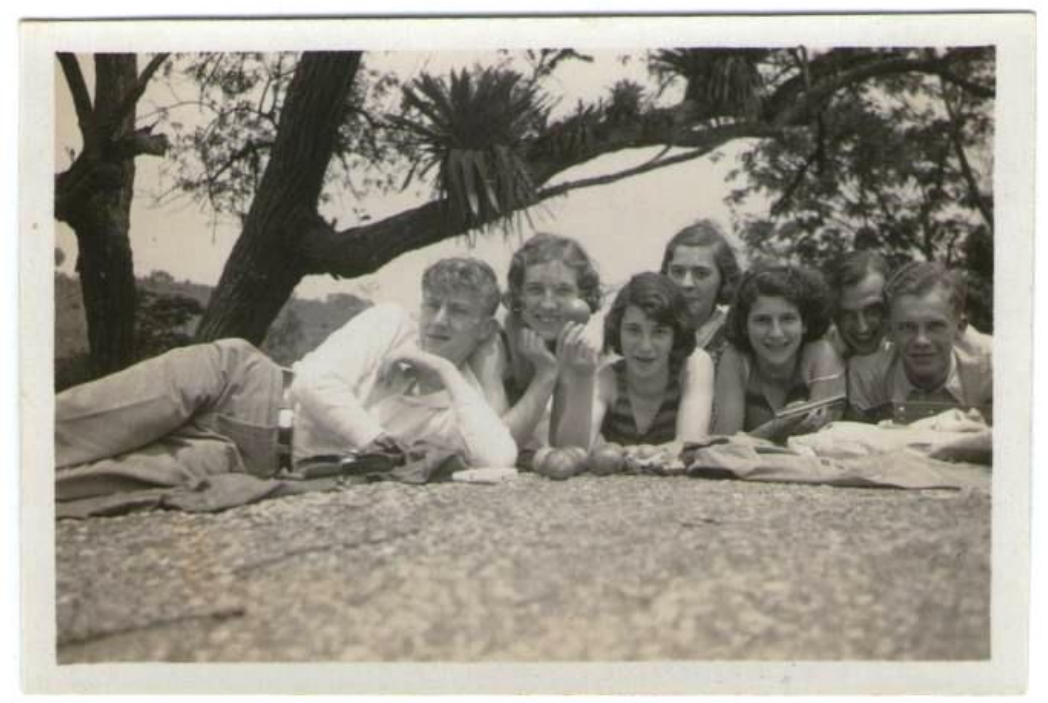

Foto 18: Cleonice e grupo de jovens em Parada de Taipas, 1934. Dimensões: 6 x 8,5 cm. Laboratório Casa Bevilacqua, Rua Direita 13, São Paulo.

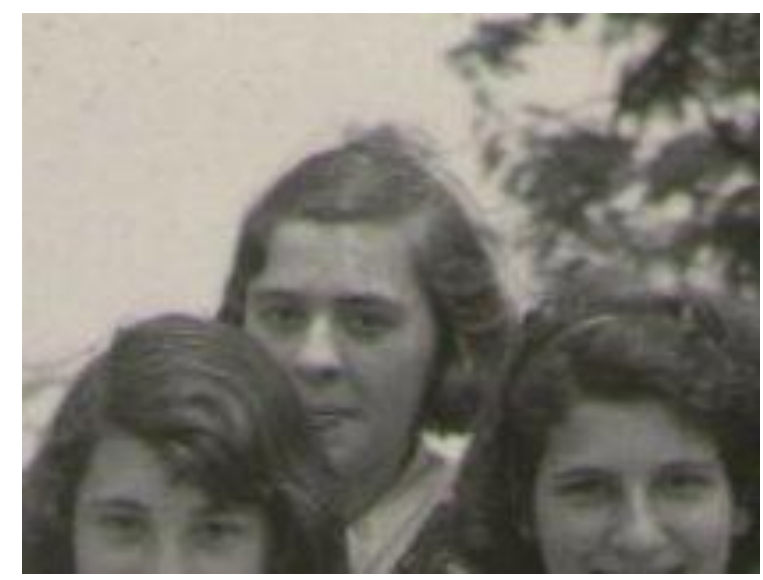

Detalhe 18a: Rosto de Cleonice. Nesta imagem, ao contrário de muitas outras, ela não estrutura a cena, e sua posição é secundária.

Esse deslocamento até Taipas lembra que os passeios campestres foram uma prática comum entre a juventude alemã já durante o século XIX. O movimento romântico ensinou a muitos jovens o gosto pelas caminhadas e pela contemplação da natureza.

Entre outros movimentos naturistas naquele país, o Wandervögel (pássaros migratórios), criado em 1896, apresentava essa verve romântica, e seus adeptos faziam passeios para contemplação da natureza, em oposição ao conforto citadino e ao utilitarismo da sociedade industrial. Bosques, montanhas, lagos e mares passaram a receber cada vez mais viandantes (CORREA, 2010: 175). 
Em São Paulo, a atuação do Partido Nacionalista envolvia as práticas de recreação por meio de um programa de "excursões campestres", divulgando um ideário nazista que, de acordo com as autoridades policiais do DEOPS/SP, eram fomentadas por escolas como o Colégio Porto Seguro, localizado no centro de São Paulo, e a Escola Alemã da Vila Mariana (DIETRICH, 2007: 246-247). O gosto pela natureza revelado pela fotografia da Freguesia do Ó, de Taipas e, mais tarde, de Santo Amaro (nos arredores paulistanos), condiz com os sentimentos da época.

É possível que Cleonice tenha estudado na (Deutsche Schule), escola alemã ${ }^{24}$ da Vila Mariana, quando chegou a São Paulo. Já moça, ela aparece nas celebrações do carnaval do ano de 1940 nessa escola como mostra a foto 19. Aí vemo-la, discretíssima no meio da multidão; está à direita e olha na direção de uma amiga (sem máscara) que a acompanhou a um passeio em 1939 e que aparece ao seu lado em uma foto instantânea de rua andando no centro de São Paulo. É a familiaridade com a personagem, permitida pela manipulação sistemática de um grande número de retratos, que torna possível identificá-la nesta imagem. Traços peculiares, como a orelha descoberta sob a boina (como pode ser conferido no detalhe, detalhe 19 a), foram indícios nesta identificação ${ }^{25}$ permitindo confirmar ser ela a moça, então com 21 anos, entre alemães e seus descendentes na capital paulista.

\footnotetext{
${ }^{24}$ Atual Colégio Benjamim Constant. Não foi possível consultar os arquivos desta escola, onde fiz várias tentativas e não obtive respostas. A propósito das escolas alemãs, cf. Ribeiro (2002) e Wernet (1989).

${ }^{25} \mathrm{O}$ método indiciário desenvolvido por Giovanni Morelli para atribuir autenticidade a pinturas do período renascentista deu especial atenção a traços até então considerados insignificantes como "lóbulos das orelhas, as formas dos dedos das mãos e dos pés". Dessa maneira, diz Ginzburg, Morelli descobriu, e escrupulosamente catalogou, a forma de orelha própria de Boticelli, a de Cosmè Tura e assim por diante: traços presentes nos originais, mas não nas cópias. GINZBURG (2003: 144).
} 


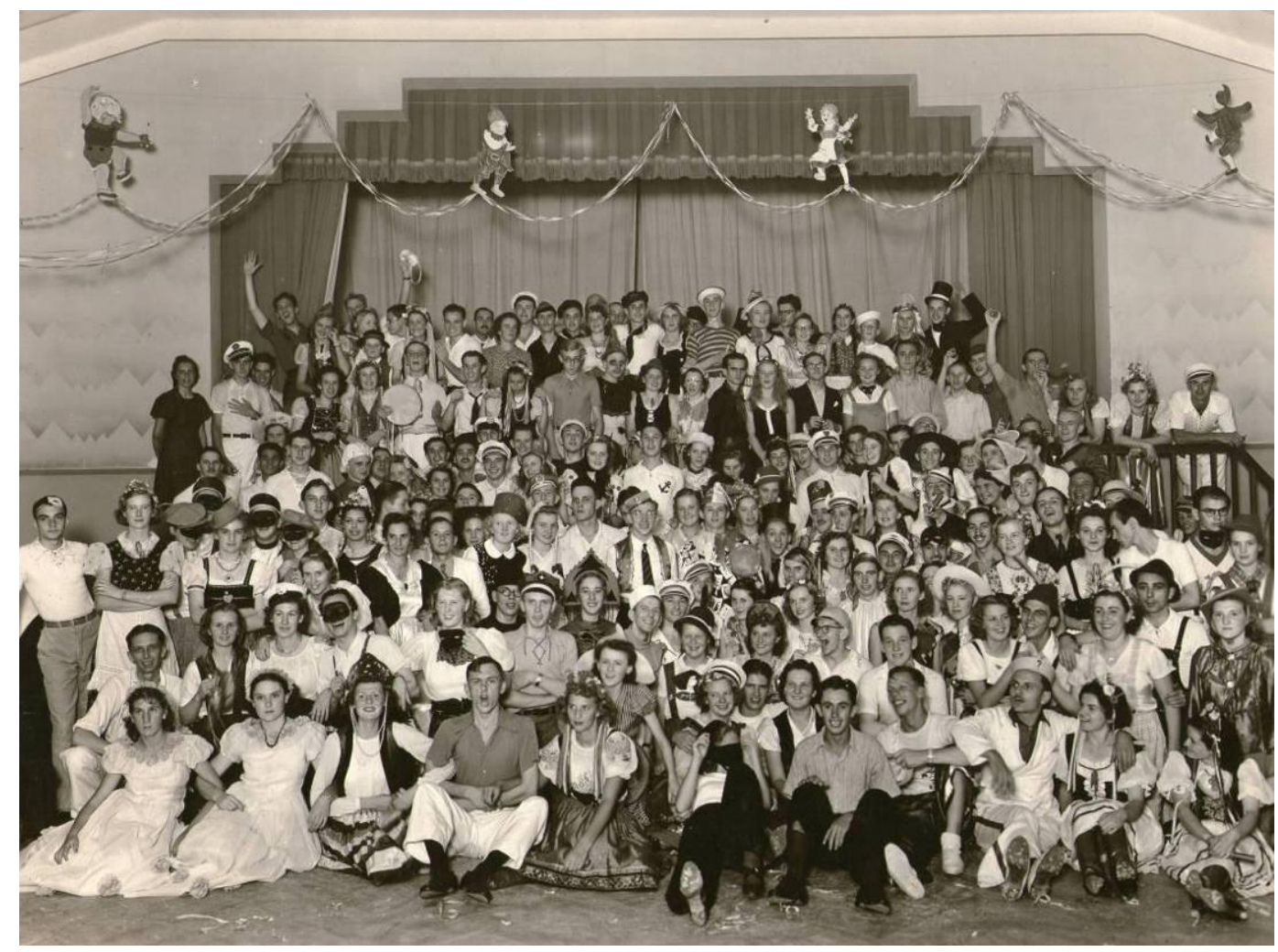

Foto 19: Carnaval na Vila Mariana Schule (escola alemã da Vila Mariana), 1940. Fotografia reduzida do original tamanho 17,5 x $23 \mathrm{~cm}$. Fotógrafo João Alt. R. São Bento, 307.

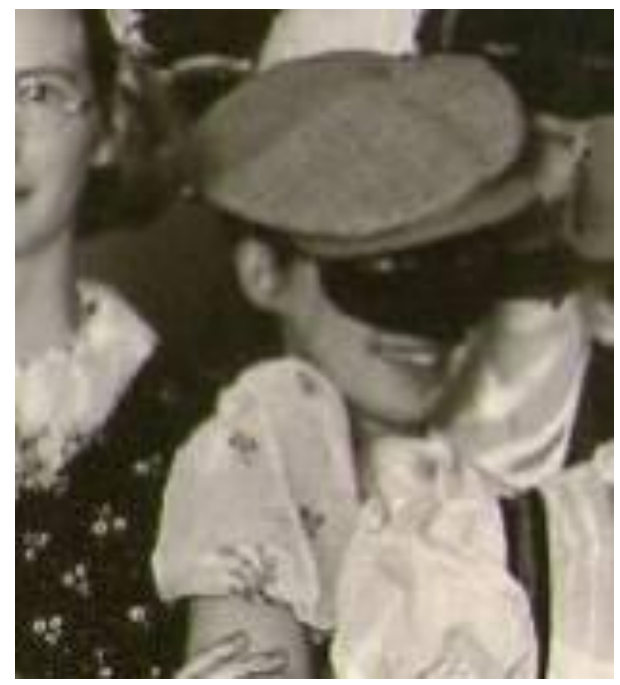

Detalhe 19a: Cleonice no retrato coletivo do carnaval na Vila Mariana Schule.

Segundo Ana Maria Dietrich, a Deutsche Schule, fundada em 1901, é uma das 1.260 escolas alemãs espalhadas pelo Brasil. É possível que Cleonice e Germano tenham estudado nesta escola desde crianças, pois há para cada um deles uma fotografia em grande formato, diante do que talvez fosse a entrada do estabelecimento que, ao que 
tudo indica, separava meninos e meninas. No período do carnaval, porém, a proximidade entre os sexos, conforme mostra a foto, era permitida, ao menos para aqueles que, à época, eram jovens adultos. $\mathrm{O}$ clima de festa nada revela das tensões sociais daquele momento.

Durante os anos 1930, como já indicado, a política nacionalista brasileira inicia um processo de hostilização dos estrangeiros, escolas alemãs incluídas. A Constituição de 1934 obriga as escolas estrangeiras a ensinarem no vernáculo, embora permitissem aulas em língua estrangeira. A situação começa a radicalizar-se com o decreto n. 383 de 18 de abril de 1938, após o Estado Novo, quando o governo suspende os direitos políticos dos estrangeiros confiscando bens de clubes, sociedades e escolas (WERNET, 1989: 5). A situação agrava-se a partir de 1940, sobretudo com a declaração de guerra à Alemanha em 1942. Neste ano, como parte de seu projeto de "caça" aos estrangeiros, o então presidente Getulio Vargas decreta a nacionalização das escolas. A Deutsche passa a chamar-se Benjamim Constant, e o português, que era língua secundária no estabelecimento, passa a língua obrigatória (DIETRICH, op.cit). Pode estar aí uma chave de explicação para o fato de haver várias legendas escritas em alemão na coleção NCW. Em outras palavras, ao estudar em uma escola da comunidade germânica, o estímulo à manutenção da língua foi mantido.

As tensões pelas quais as comunidades germânicas passaram, em especial nos grandes centros urbanos como Rio de Janeiro e São Paulo, transparecem no desaparecimento gradativo do uso da língua alemã para identificar os eventos fotografados na coleção CMH.

Antes dessa foto de carnaval na escola alemã Cleonice havia participado de festa similar dois anos antes. Em 1938, então com 19 anos, ela é fotografada ao lado de duas moças que, suponho, possuem algum grau de parentesco com a personagem, pois são as mesmas que aparecem no passeio a Parada de Taipas e em outras ocasiões. Infelizmente, não há nada que permita identificá-las. Na foto 20 , as três estão trajadas de espanholas, embora as duas não identificadas apareçam em outra série de fotografias vestidas de homens (mas não Cleonice) ${ }^{26}$. É interessante observar que o carnaval permitiu que elas, descendentes de imigrantes, brincassem com a representação do elemento estrangeiro na cidade.

\footnotetext{
${ }^{26}$ É curioso notar ainda que a palavra "carnaval" é grafada diferentemente no verso da fotografia de 1940 com a letra $\mathrm{C}$, ao passo que na foto 20 é escrita com K. Pequenas alterações, sem dúvida, que embora não modifiquem o sentido da informação, apontam para a plasticidade da linguagem escrita na identificação das cenas registradas.
} 


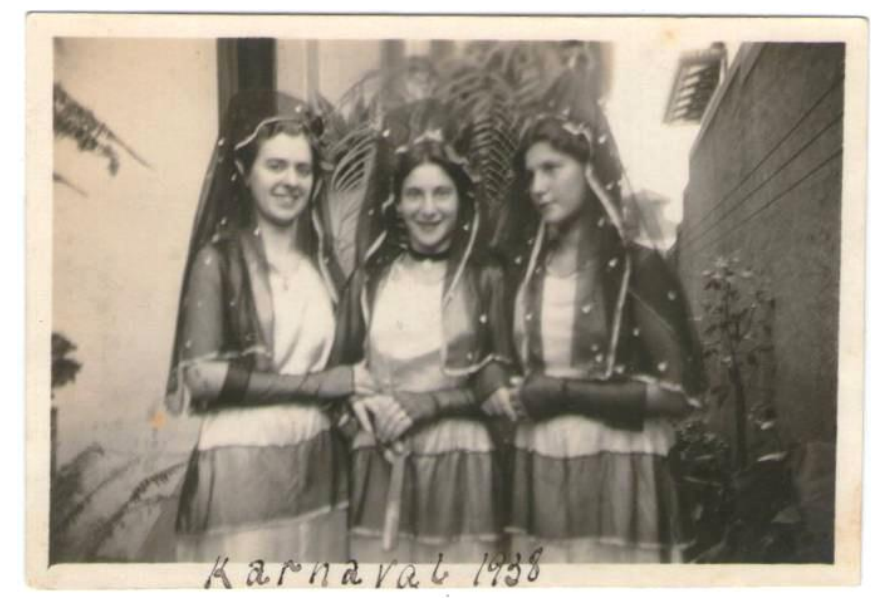

Foto 20: Cleonice à esquerda entre possíveis primas ou amigas de São Paulo que também aparecem no passeio a Taipas em 1934. Retrato do Karnaval de 1938. Dimensões: 6 x $8,5 \mathrm{~cm}$.

A ascendência alemã, ressaltada na foto 19 dá lugar aí à representação convencional - quase caricata - das mulheres espanholas. Se as duas moças (primas?) somem completamente a partir de 1938, outras personagens entram em cena. É difícil conjeturar sobre seus destinos uma vez que não deixaram quaisquer outros rastros na coleção. A essa ausência corresponde o aumento da rede de sociabilidades de Cleonice e, a esta, o incremento do consumo de fotografias e a diversificação dos motivos das imagens. Um deles é a recreação esportiva em parques públicos como o Parque da Água Branca ou o Parque das Orquídeas (que não mostro aqui) e em clubes privados. 


\subsection{O Clube de Regatas Tietê}

$\mathrm{Na}$ foto 21 (que faz parte de uma série de 24 imagens), Cleonice aparece correndo, primeiramente sozinha e um tanto desfocada, e depois ao lado de uma amiga (foto 22).

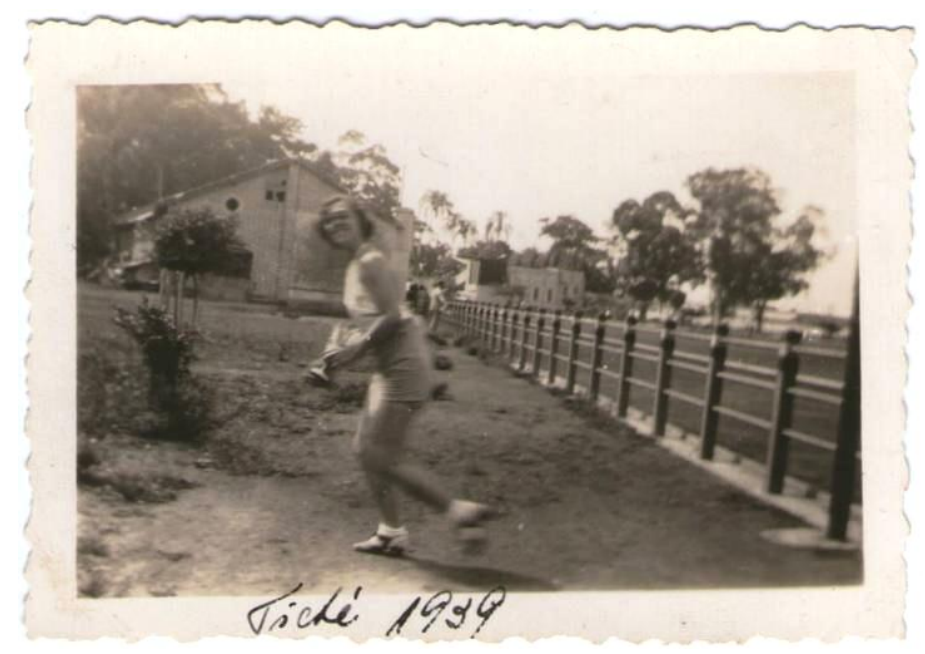

Foto 21: Cleonice no Clube de Regatas Tietê faz corrida e é como se dissesse: não dá para descansar nem para um retrato. A ordem ainda é movimentar-se. Dimensões: 6 × $9 \mathrm{~cm}$.

A jovem gosta muito de ser fotografada, a ponto de não deixar de interagir com a câmara mesmo enquanto pratica esportes. O efeito desta interação com o fotógrafo é que as imagens perdem definição e qualidade, o que assinala as dificuldades da captação dos movimentos rápidos pelo equipamento amador. 


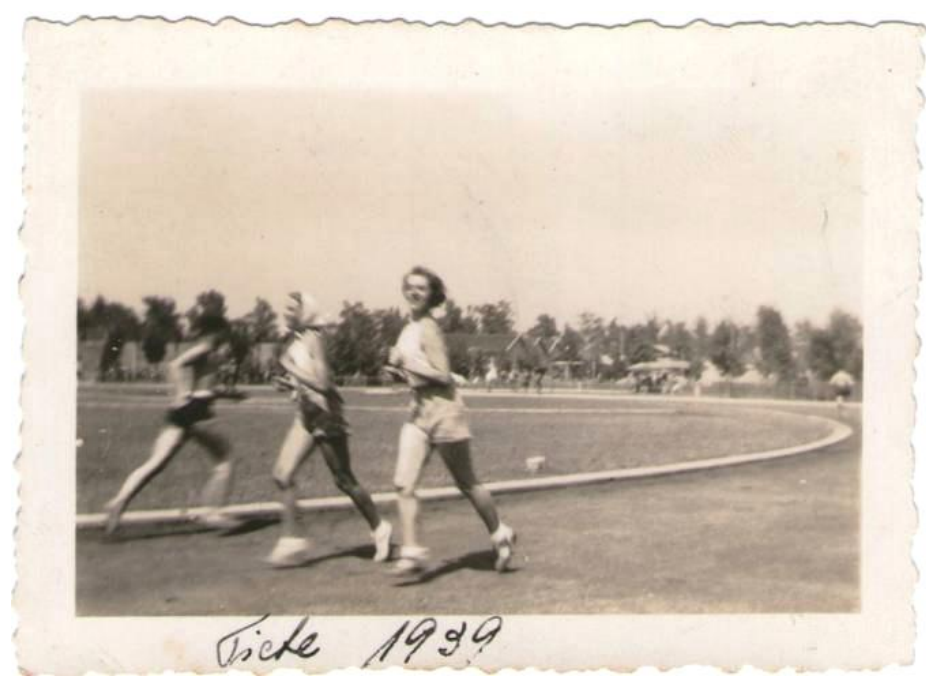

Foto 22: Cleoniceno Clube de Regatas Tietê. Dimensões: 6 x 9 cm.

O ambiente esportivo em que Cleonice se fez fotografar, era o já estabelecido Club de Regatas Tietê fundado em $1907^{27}$. Nesse fim da década de 1930, a difusão das práticas esportivas entre a juventude era fato um tanto costumeiro. $\mathrm{O}$ estímulo a tais práticas pelo Estado tinha forte ligação com a educação moral e com o apelo nacionalista da época. No contexto do Estado Novo, os esportes, em especial, adquirem importância, pois são associados à saúde e ao bem-estar físico e mental. Nesse sentido, sua função era produzir sujeitos (homens e mulheres) dispostos a realizarem o ideal da nação físicamente saudável, disposta a construir o país com seu trabalho profissional e, adicionalmente, no caso feminino, gerando bons filhos.

Todavia, é na década anterior que se observa o incremento e a difusão do gosto pelos esportes. Nicolau Sevcenko acompanha a criação e desenvolvimento do imaginário ligado às práticas esportivas, que tomou a capital paulista, espalhando-se, por todos os cantos da cidade. Ninguém mais podia ficar parado e o lema era a "mobilização permanente":

A lista de fato é enorme e incluiria várias modalidades de provas pedestres, náuticas, ciclísticas, motociclísticas, automobilísticas, provas de natação, nado coordenado, saltos ornamentais, provas de tiro, esgrima, polo, boxe, luta romana, ginástica sueca, ginástica com aparelhos, ginástica rítmica, demonstrações coletivas, beisebol etc. (SEVCENKO, 2003, 44).

\footnotetext{
${ }^{27}$ Sobre a história deste rio, consultar: JORGE, 2006; PEREIRA 1995.
} 


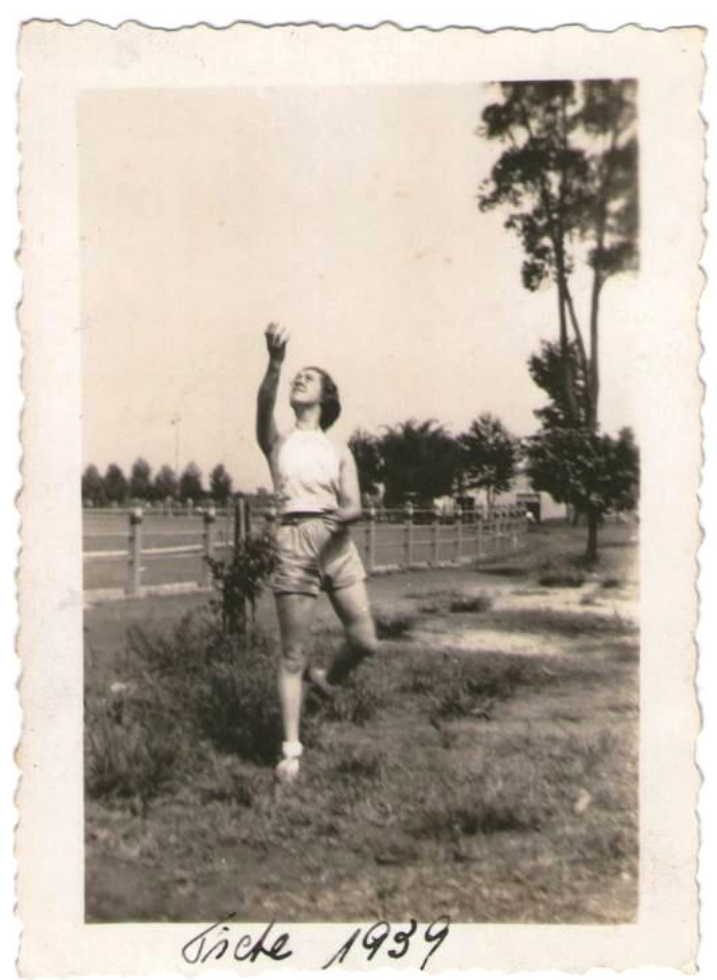

Foto 23: Cleonice no Clube de Regatas Tietê em 1939. Dimensões: 6 x 9 cm.

Nesse contexto, não era impossível que Cleonice tivesse praticado algum esporte já durante a infância, e as imagens no Clube de Regatas mostram sua intimidade com as práticas esportivas na juventude. Mas nem todo esporte era indicado às mulheres, alvos privilegiados da ideologia estadonovista, que pregava ser seu papel moral trazer ao mundo filhos robustos educados para o engrandecimento da nação brasileira. Às mulheres cabiam os esportes "delicados", indica Susan Besse, que deviam ser praticados para aumentar a flexibilidade, a agilidade, a harmonia, o ritmo e a graça. Em suas palavras:

Natação, dança clássica, ginástica sueca, esgrima e tênis de mesa estavam entre as formas de exercício consideradas mais adequadas. Remo, ciclismo, corrida, voleibol e basquetebol eram recomendados apenas com moderação. Considerados totalmente inadequados eram os esportes "violentos", tais como futebol, boxe, luta romana, levantamento de peso, corridas de longa distância e salto em altura. (BESSE, 1999: 139).

Não esqueçamos ainda o discurso da Igreja Católica que, embora reconhecesse a importância da educação física afirmando que "quanto mais forte e sadio for o indivíduo, tanto melhor para a vida cristã", não podia tolerar, contudo, o "crasso 
materialismo que só aceita a educação do corpo" (SILVA, 1940: 8). Tal prescrição tinha por fundamento assegurar e facilitar as "atividades humanas específicas superiores" como advertia Pio XI (idem, p.9). Em sua carta à Pastoral Coletiva do Episcopado da Província Eclesiástica de São Paulo sobre a defesa da fé, da moral e da família, o arcebispo de São Paulo deixa clara a posição da Igreja quanto à educação física para as jovens mulheres:

Somos, nada obstante, contra a masculinização da juventude feminina, pois basta a mais breve e ligeira atenção para ver que essas jovens assim educadas jamais se resignam às condições do seu sexo, vivendo - quantas! - em perpétuo estado de revolta e inadaptação. Que se façam exercícios destinados a fortalecer os músculos, não o condenamos. Ultrapassar, porém, os limites, entusiasmá-las pelos desportos, bastante impróprios à sua natureza, é deseducar, desambientar a mulher. (SILVA, 1940: 9).

É razoável supor que ecos desse discurso tenham chegado aos ouvidos de Cleonice, pois ela, em 1940, já conhecia o Sr. Conrado José Velloso de Souza Filho e talvez até mesmo sua esposa, Dona Olga Medeiros de Souza, que, ao que tudo indica, eram católicos. Seria possível também supor que Cleonice não tenha dado tanta atenção a tais prescrições, em função de sua convivência com a comunidade protestante germânica e da falta de vínculos com o catolicismo.

De qualquer forma essas são conjecturas de difícil demonstração, pois além do contato que mantinha com os primos de Brusque, nada sugere que ela tivesse relações com os protestantes da comunidade alemã em São Paulo. Na realidade, as poucas imagens de ritos de passagem familiares ou religiosos, sobretudo católicos, aparecem na coleção como presentes recebidos por Cleonice. Por exemplo, algumas fotos de Dircinha, filha do casal Souza, em sua primeira comunhão. É possível que ela tenha começado a se sensibilizar ${ }^{28}$ com a fé católica em decorrência da convivência com a família Souza de maneira que o ápice dessa sensibilização seria seu batizado em 1960 (foto 10).

\footnotetext{
${ }^{28}$ Ver: OWENSBY, 1999: 227. Para este autor o desenvolvimento de uma sensibilidade religiosa católica foi um dos elementos importantes na conformação das classes médias urbanas no Brasil.
} 


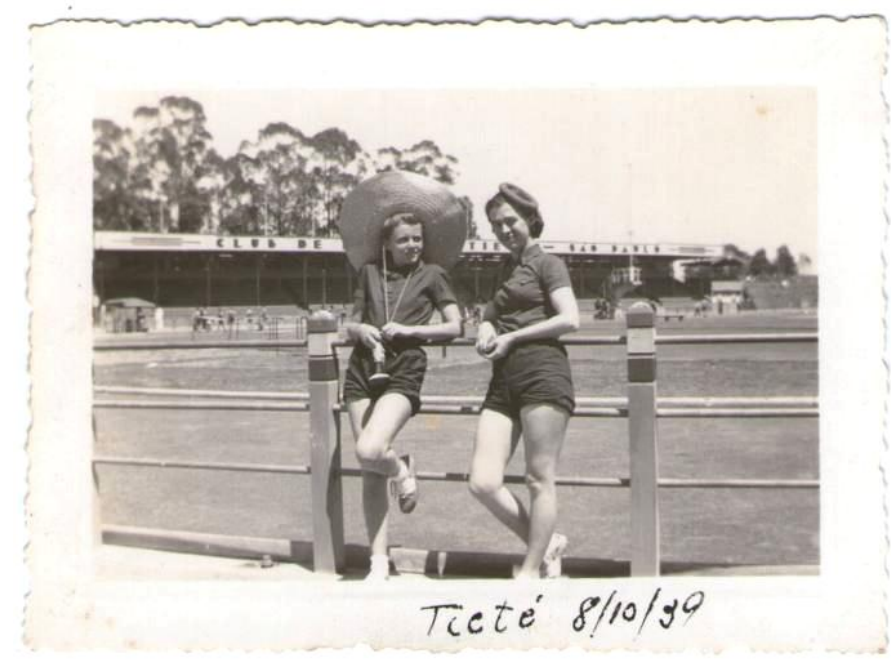

Foto 24: Cleonice ao lado de uma amiga não identificada no Club de Regatas Tietê em 8/10/39. Dimensões: 6 x $9 \mathrm{~cm}$.

$\mathrm{Na}$ foto 24, Cleonice está à esquerda de uma amiga anônima tendo ao fundo a fachada interna do Club de Regatas Tietê identificado pelo letreiro (detalhe 24 a). Não há, na sequência de imagens deste passeio, qualquer visão panorâmica do clube. Por outro lado, um mesmo elemento, a cerca, unifica os diferentes espaços nos quais ela aparece só (fotos 21 e 23) e acompanhada (fotos 22 e 24). Nesse sentido, é como se a cerca fosse uma mesma linha a perpassar e unificar as fotos, pois a fotografia fragmenta o espaço real.

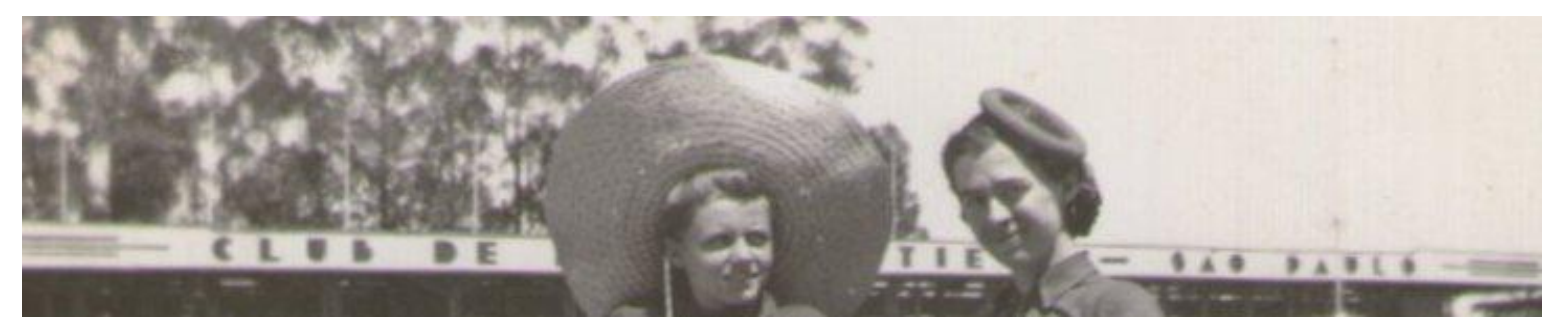

Detalhe 24 a: A amiga olha com certa curiosidade para a sua esquerda, pois Cleonice colocou na cabeça um dardo, círculo para se jogar ao ar e pegá-lo quando este cai em direção ao chão. Possivelmente Cleonice o jogava como na foto 23 , na qual ela parece esperar a queda de um objeto lançado para o alto.

$\mathrm{Na}$ foto 25 , Cleonice à esquerda anda ao lado de outra amiga (que também figura na foto 19). Ela estava com vinte anos de idade e trajava, aparentemente, o mesmo modelo que já havia usado em Santos (foto 51). As amigas aparecem em várias fotografias da segunda metade dos anos 30 e início dos anos 40. Essa mesma amiga aparece em uma ampliação de $17 \mathrm{~cm}$ x $12 \mathrm{~cm}$ em um passeio ao Clube de Regatas Tietê.

Embora essas pessoas façam parte da rede de relações de Cleonice, elas ficaram 
anônimas, porque não foram referenciadas na legenda. Esse anonimato é recorrente na coleção. A falta de atenção aos nomes sublinha o desinteresse de Cleonice como sujeito acumulador em identificar as pessoas, embora haja um esforço classificatório em relação a lugares e datas. Obviamente, isso tem a ver com o fato de que ela conhecia as pessoas retratadas, pois se trata de registros cuja circulação é bastante restrita e não raro são imagens que participam de um circuito no qual todos os fotografados eram conhecidos não sendo, pois, necessário proceder à anotação de seus nomes.

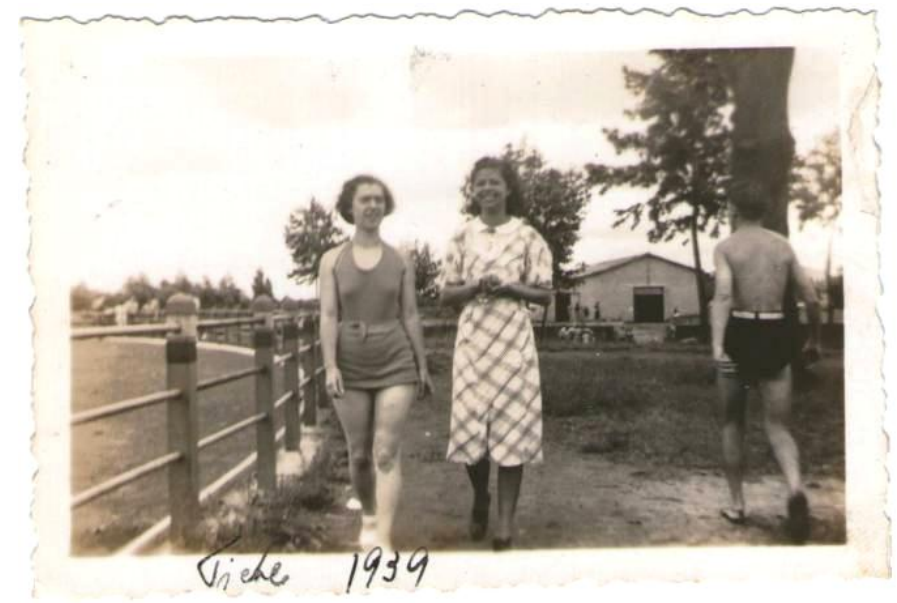

Foto 25: Cleonice anda nas alamedas do Club de Regatas Tietê usando o mesmo traje que já havia usado na praia em Santos em 1936. Dimensões: 6 x 9cm.

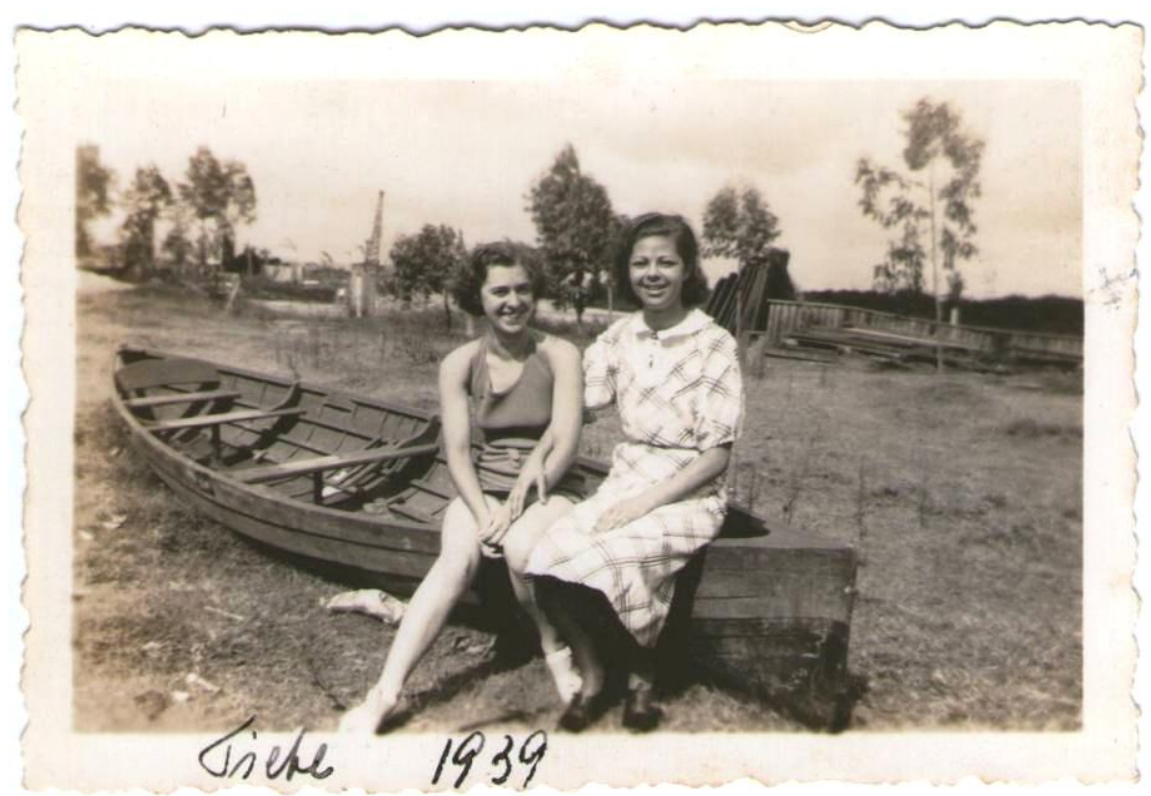

Foto 26: Cleonice e amiga anônima no Club de Regatas Tietê, 1939. Ampliação 12 x 8 a partir do original. Dimensões: 6 × $9 \mathrm{~cm}$. 


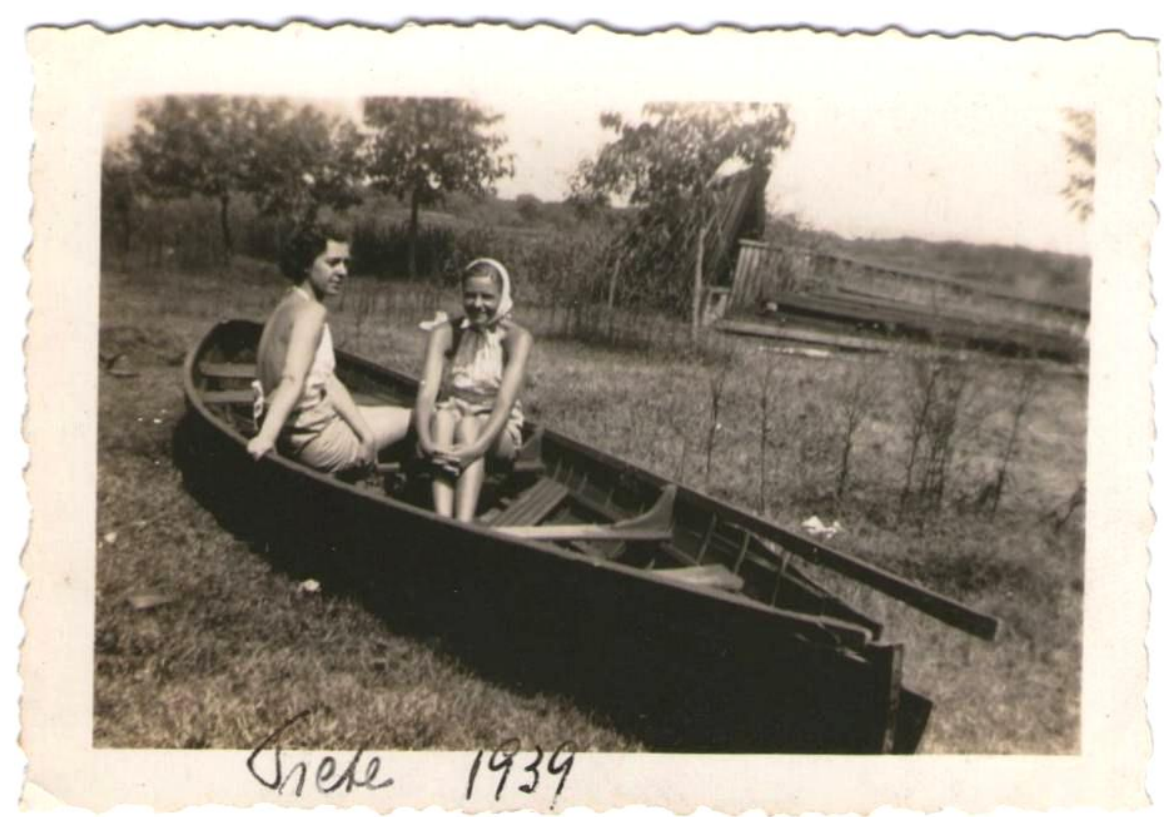

Foto 27: Cleonice e amiga anônima no Club de Regatas Tietê, 1939. Ampliação 12 x 8 a partir do original. Dimensões: 6 × $9 \mathrm{~cm}$.

Nas fotos 26 e 27, elas fazem uma pose em uma embarcação fora de uso no Clube de Regatas Tietê. $\mathrm{O}$ trecho em que estão parece árido: poucas árvores; ao fundo, tábuas amontoadas entre o mato rasteiro. Bem perto de Cleonice (foto 26), sob seus pés parece haver lixo, elemento indicativo dos usos e práticas desse espaço. É impossível não observar nesta imagem o contraste entre a indumentária de Cleonice, cujo corpo encontra-se mais exposto que o de sua amiga. Trata-se aparentemente de um mesmo ambiente visitado no mesmo ano, mas em diferentes momentos.

Já nas fotos 28, 29 e, 30, feitas no mesmo ano, mas não na mesma época, as duas aparecem em cima de uma árvore, e a amiga da foto 26 encontra-se agora em trajes mais despojados. Ambas posam para a série de fotos variando a pose: na foto 28 , ocupam lugares opostos (a amiga reclina-se meio sentada, enquanto Cleonice se deita); na foto 29, por sua vez, a moça está de pé enquanto Cleonice está sentada no tronco, mas em posição mais elevada; finalmente, a foto 30 mostra ambas sentadas (Cleonice, mais ousada posiciona-se, nas três imagens, no galho mais alto).

A tomada de baixo para cima revela a posição do fotógrafo que retratou as moças equilibrando-se sob os galhos retorcidos da árvore. 

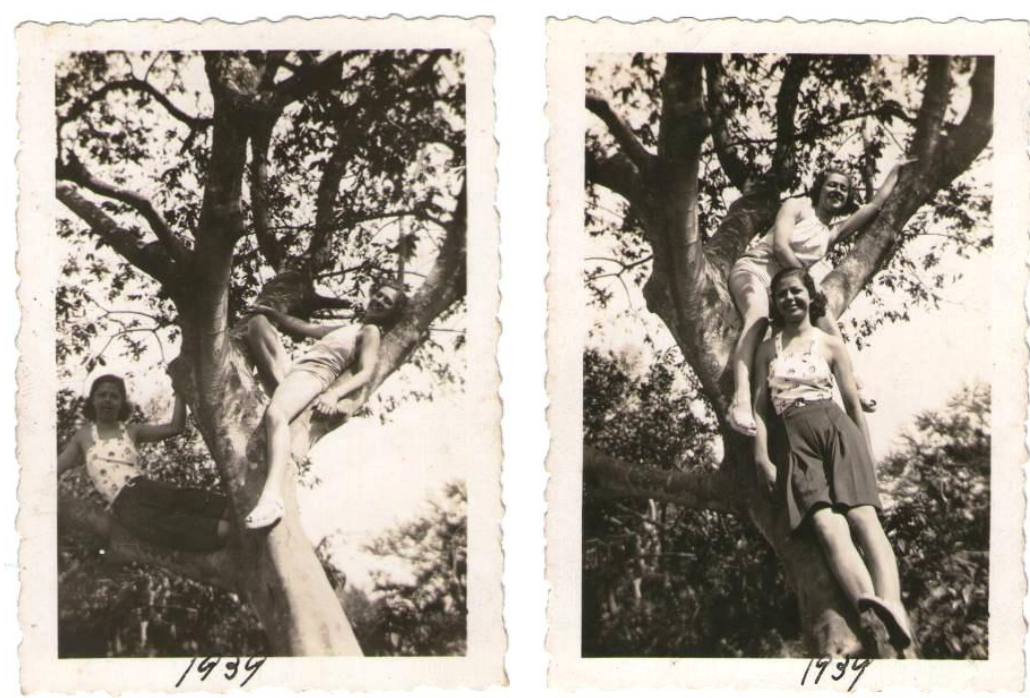

Fotos 28 e 29: Cleonice e amiga anônima. Clube de Regatas Tietê, 1939. Redução das dimensões originais: $6,5 \times 9 \mathrm{~cm}$.

Diferentemente das duas imagens anteriores, cujo enquadramento e luminosidade intensa do fundo não permitem que o olhar se desvie das mulheres, na foto 30 o espaço ampliado permite observar águas que devem pertencer ao próprio rio Tietê. O ambiente é assim constituído pela visão do fotógrafo, de maneira pitoresca (uma visão, diga-se informada pela cultura visual da época). Percebe-se, pois, a relevância da fotografia que vinha se afirmando como um importante modo de ver, experimentar, produzir e memorizar experiências com o mundo visível.

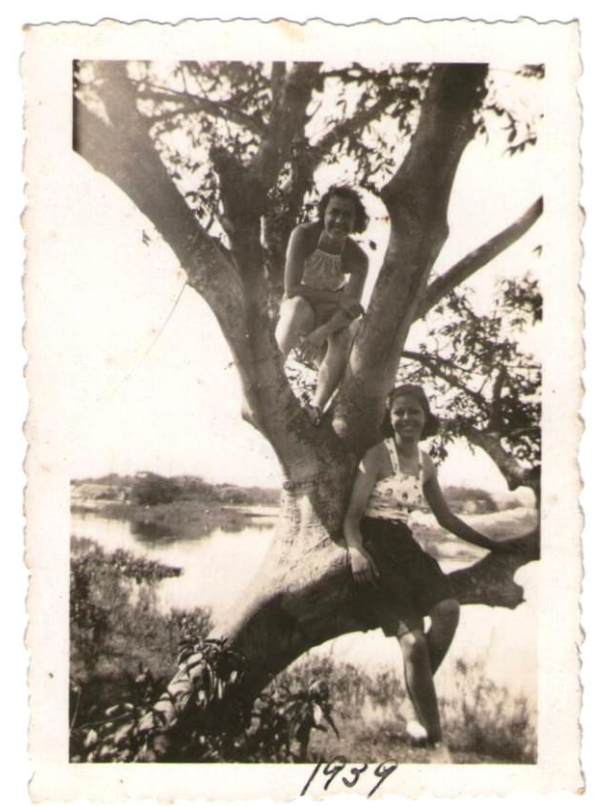

Foto 30: Cleonice e amiga anônima. Clube de Regatas Tietê, 1939. Ampliação das dimensões originais: 6,5 x $9 \mathrm{~cm}$. 


\subsection{Represa de Santo Amaro: Praia Azul e Riviera Paulista}
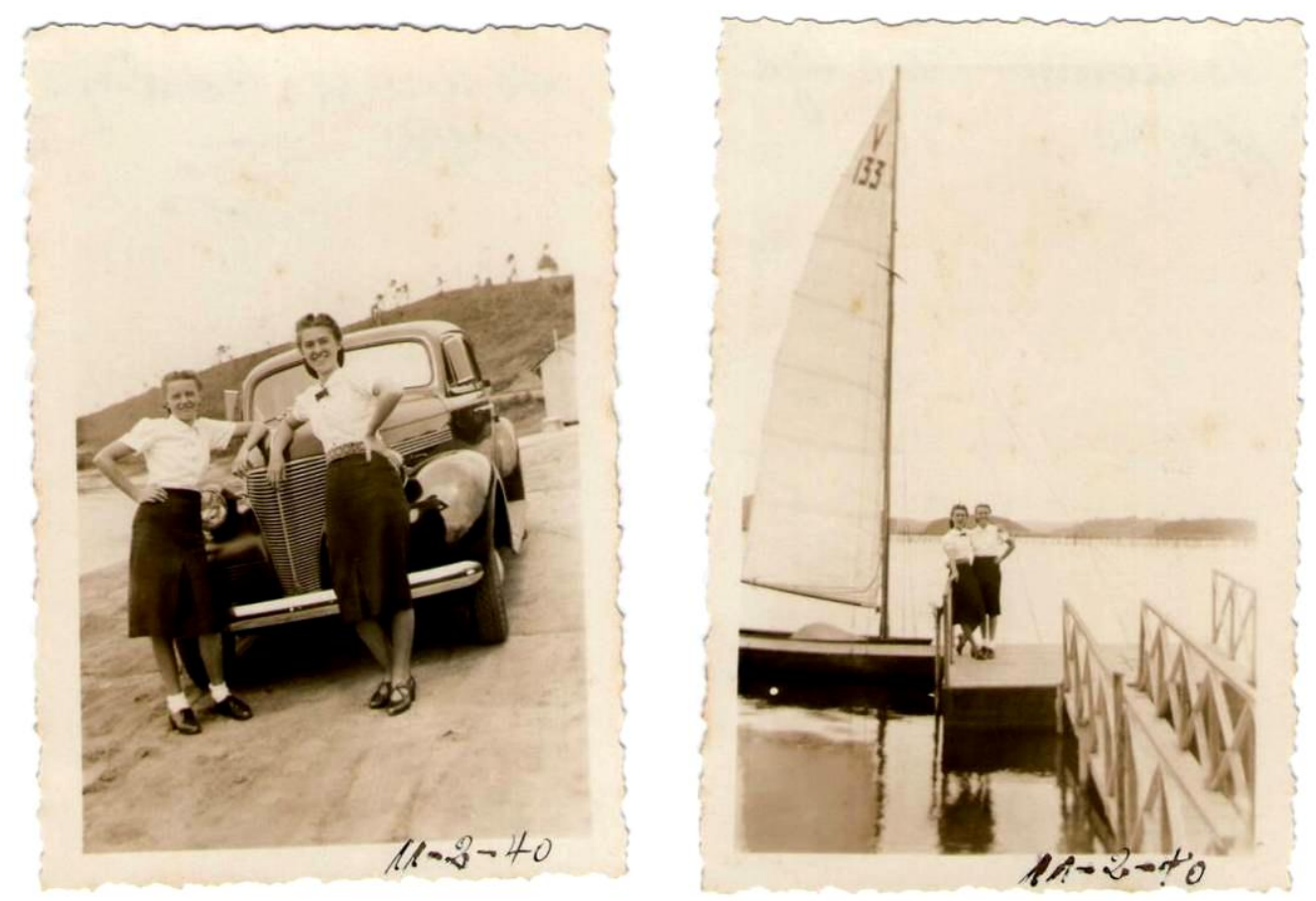

Foto 31 e 32: Cleonice e amiga em Santo Amaro, Praia Azul, 11-2-1940. Dimensões: 6 x 9 cm.

No verão de 1940, Cleonice vai a Santo Amaro na Praia Azul e na Riviera Paulista (fotos 31 e 32). A pose diante do carro demonstra que as moças e a pessoa que as fotografou chegaram ao destino de automóvel. Sabemos que até os anos 1930 somente as elites fazendeiras possuíam carros e que a partir de 1940, uma classe média alta também passou a adquiri-los (INOUE, 2011: 175). Cleonice, portanto, mantinha vínculos sociais com gente abastada.

Cinco anos antes da captação de tais imagens, o Jornal O Estado de S. Paulo publicava um anúncio sobre a “Auto-Estrada" 29 " que levava à Represa de Santo Amaro. $\mathrm{Na}$ margem da estrada, os terrenos postos à venda podiam ser admirados e/ou adquiridos. Informava o jornal: "Vende-se 7 alqueires mais ou menos 400 metros de

${ }^{29}$ S/A Auto-estradas era o nome de uma empresa fundada em 1929 "que ambicionava implementar lucrativos negócios imobiliários na região e construiu uma estrada de rodagem que interligava São Paulo a Santo Amaro". (JORGE, 2006: 129). 
frente à represa lugar de grande futuro em frente à praia Azul, com barco. 50 contos. Mais informações largo de S. Efigênia ${ }^{30}, 15$ - tel. 4 - 2472," (O Estado de S. Paulo, apud JORGE, 2006: 130). Este foi um dos poucos dados que encontrei sobre a localidade; embora breves, as informações são relevantes para compreender como Santo Amaro começou em meados da primeira metade do século XX a transformar-se em polo de diversão para os moradores da capital. Até 1934, era um município com autonomia administrativa; em 1935, foi anexado à capital, tornando-se mais um bairro paulistano. Seu desenvolvimento ocorreu de modo semelhante a outros lugares que passaram a manter comunicação cada vez mais intensa com a cidade de São Paulo, a partir de fins do século XIX. Esse contato entre os arredores e a capital constituiu-se em fator determinante para o progresso de bairros inteiros e, como mostrarei nos próximos capítulos, modelou novos destinos recreativos como o litoral e o campo.

O enriquecimento da cidade de São Paulo causa impacto no seu entorno, transformando suas funções originais, como no caso de Santo Amaro que, até meados do século XIX, fornecia gêneros alimentícios, madeiras, carvão e pedra de cantaria ${ }^{31}$ à capital (RIBEIRO, 2002:58). Todavia, tal comunicação não se faz aleatoriamente, ela vem acompanhada da circulação de produtos, coisas, símbolos e pessoas. Em 14/3/1886, é inaugurada a ferrovia que ligava Santo Amaro à capital e, mais tarde, o trecho é adquirido pela firma Light and Power em 1900. Se a ferrovia é o símbolo mais eloquente da modernidade do período, instrumento útil à circulação, é possível dizer o mesmo em relação à fotografia: ela colocou em circulação a variedade e a diversidade do mundo visível (KOSSOY 2010; ROUILLÉ 2009; SONTAG 2004; BARBUY 2002; BARTHES, 1984). Lembremos que, em 1913, a linha férrea Santo Amaro-São Paulo é substituída pela Linha de Bonde Elétrico. Já em 1908, a mesma empresa começa as obras da Represa de Guarapiranga para a construção da Usina Hidrelétrica de Paranaíba, modificando assim o nome da então Represa de Santo Amaro.

Em 1930, é fundado o Yacht Club de Santo Amaro ${ }^{32}$. Nota Janes Jorge como

\footnotetext{
${ }^{30}$ O Estado de S. Paulo, 16/6/1935, p.21.

31 "Por definição, a cantaria é entendida por pedra lavrada ou simplesmente aparelhada em formas geométricas para construção de edifícios e, em geral, para qualquer construção. As rochas são cortadas segundo as regras da estereotomia, esta definida como "a arte de dividir e cortar com rigor os materiais de construção", a fim de serem aplicadas às diferentes partes do edifício, como constituição das paredes, etc". Disponível em: http://www.revistamuseu.com.br/emfoco/emfoco.asp?id=8901. Acesso em 23/5/2012.

${ }^{32}$ No site do Instituto Hans Staden é apresentada uma exposição virtual com 30 fotos sobre São Paulo produzidas entre 1883 e 1960. Entre as imagens há uma fotografia da antiga Represa de Santo Amaro. Disponível em: http://www.martiusstaden.org.br/Events/MemoriasDeSP.aspx acesso em 24/01/2012.
} 
Santo Amaro (e a represa), comparativamente ao Clube de Regatas Tietê, por serem afastadas das áreas mais populosas da cidade, mantinham moradores pobres e proletários à distância. Diz ele: "Sintomaticamente, a região acolheria clubes de iatismo, mas não de remo" (2006: 129). A represa tornara-se local de recreação e passeio, constituindo-se um lugar da moda. Ainda que a zona já fosse valorizada em meados da década de 1910, de acordo com Langenbuch: "Varias chácaras recreativas, ostentando belas vivendas, passaram a perfilar às margens da represa de Guarapiranga. Um trecho de sua margem ocidental foi pretensiosamente denominado Riviera Paulista" (1971: $163)$.

Ora, Cleonice, sua amiga anônima e o fotógrafo puderam circular tanto na Praia Azul quanto na Riviera, levados por um automóvel, importante objeto de distinção e diferenciação social (foto 31). O veleiro que aparece na foto 32 é um símbolo do tipo de lazer ali oferecido. Aqueles que para lá se dirigiam (muitos de bonde elétrico) buscavam a contemplação da natureza, o descanso para fazer piquenique e praticar esportes náuticos (idem: 129).

Nas fotos 33 e 34, é possível visualizar a aparência concreta destes lugares. Na primeira, vê-se a ponte que leva ao imenso lago (que não é o mesmo onde o veleiro da foto 31 descansa). A verticalidade da vela contra o fundo excessivamente iluminado e pastoso ressalta manchas distantes, que são as montanhas, permitindo identificar a linha do horizonte que, se não aparecesse na foto, causaria a sensação de desorientação completa $^{33}$. Como na foto 31 , há aí o veículo, que cumpre o papel de dar mobilidade; já o veleiro figura como um artefato, cuja presença caracteriza o lugar onde essa prática esportiva tinha especial apelo. A foto 33 aproxima o fotógrafo das moças e, caso não houvesse qualquer identificação, seria possível confundir a Praia Azul com o trecho em que estão: a Riviera.

\footnotetext{
${ }^{33}$ Cf. Rubens Fernandes Júnior no texto sobre a exposição "Pittoresco" do fotógrafo Antonio Saggese no Instituto Tomie Ohtake em 2010.
} 


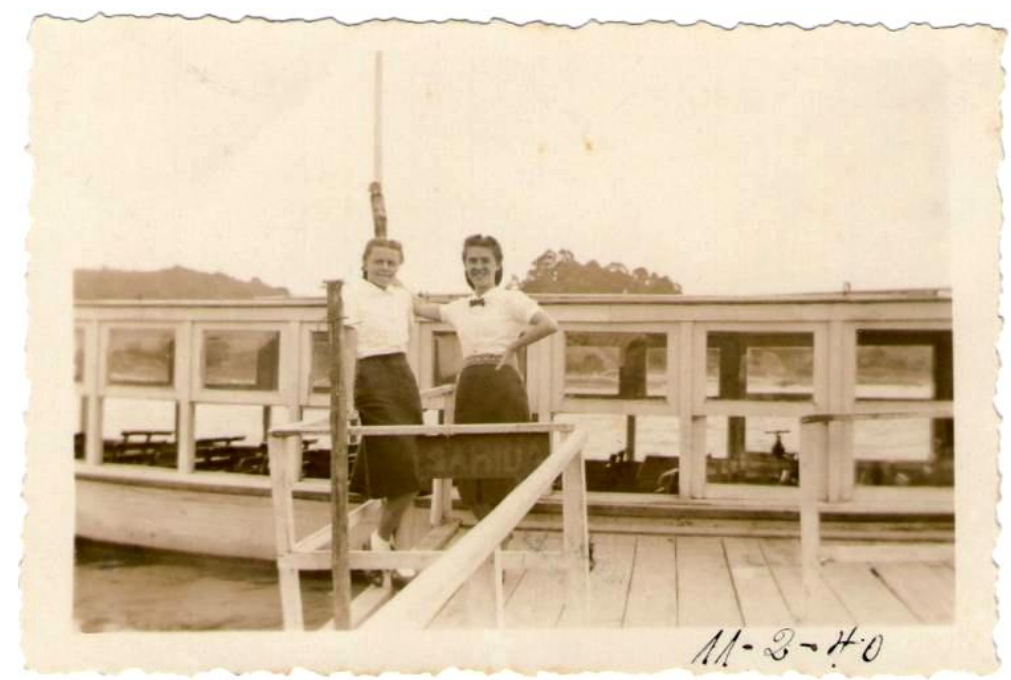

Foto 33: Cleonice e amiga anônima em Santo Amaro, Riviera, 11-2-1940. Dimensões: 6 x $9 \mathrm{~cm}$.

$\mathrm{O}$ fato de haver em ambas as imagens uma ponte poderia levar a esta confusão, desfeita, porém, quando se observa que a ponte da foto 33 apresenta padrão geométrico diferente do detalhe 32 . Observemos:

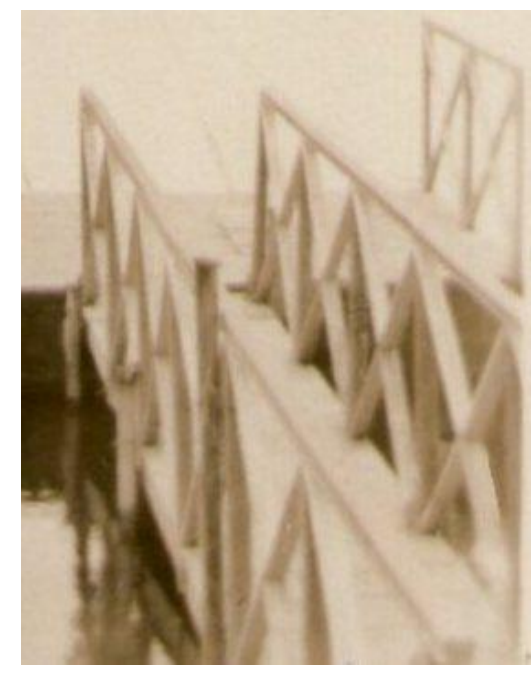

Detalhe 31 a: ponte.

Observemos ainda que Santo Amaro, como Cleonice conheceu, nada tinha a ver com a "Colônia Velha" localizada a 35 quilômetros de Santo Amaro formada em 182728 e que rapidamente entrou em decadência (RIBEIRO, 2002: 75).

Porém, este não é o único grupo que se instalou na região; houve aqueles que, ao chegarem, percebendo as difíceis condições, trataram de fixar-se como sitiantes no sertão de Santo Amaro, uma vasta área que começava na região da Capela do Socorro e 
estendia-se até o alto da Serra do Mar nos limites com São Vicente e Itanhaém. A foto 34 , apesar de oferecer somente um fragmento de paisagem ao fundo permite ter uma noção da extensão dessa área em 1941.

As palmeiras evocam o ambiente litorâneo, e a água à distância assinala os limites com o mar. Conforme Janes Jorge, o município de Santo Amaro, na primeira década do século XX, era "cercado de matas e praias", características que tornaram a região um "ponto turístico" apreciado pelos paulistanos (JORGE, 2006: 129).

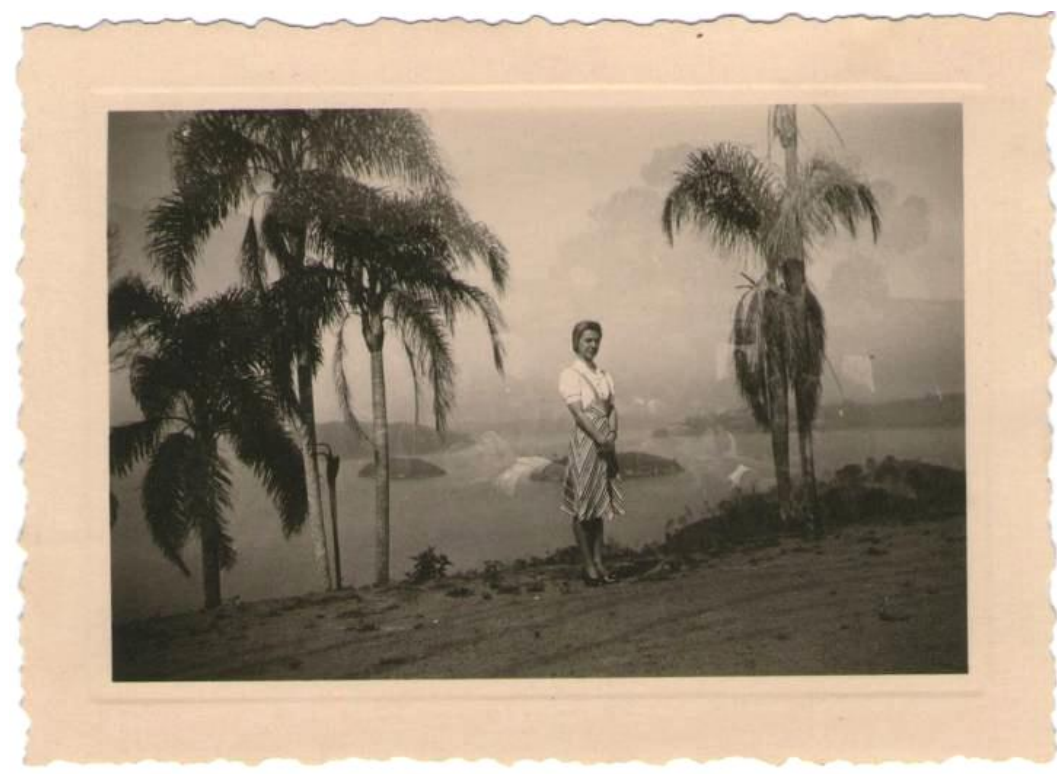

Foto 34: Cleonice na Praia Azul em 13/7/41. Ampliação das dimensões originais: 6 x $9 \mathrm{~cm}$. Papelaria Léo. Papel Agfa Lupex.

Para termos uma ideia mais clara das atrações oferecidas pela região, olhemos para Isto é São Paulo - 96 flagrantes da capital $^{34}$, lançado em 1951 pelas Edições Melhoramentos. Trata-se de um volume ricamente ilustrado com fotografias de Alice Bril, Francisco Schlater, Léon Liberman, Max Wirth, entre outros. A legenda de uma das imagens expostas nesta publicação informa: "Buscando descanso do estafante trabalho diuturno, o paulistano passa o fim de semana nos pitorescos arredores montanhosos... e no ambiente bucólico da região lacustre de Santo Amaro" (MELHORAMENTOS: 1951:70). Tais palavras indicam que, ainda na década 1950, a região era procurada pelos paulistanos, que para lá acorriam em busca da paisagem

\footnotetext{
${ }^{34}$ A propósito deste álbum e da produção de álbuns fotográficos sobre a cidade de São Paulo editados pela Editora Melhoramentos, ver CARVALHO \& LIMA (1997: 22-27).
} 
bucólica e do ambiente peculiar. Paralelamente a essa fuga para os arredores nos fins de semana, que se intensificará ao longo dos anos 40, ocorria um novo surto de remodelação urbana na região central, no qual edifícios e casas residenciais ou comerciais do período colonial, do século XIX e primeiras décadas do século XX, estavam vindo abaixo em nome do progresso da cidade ${ }^{35}$.

Cleonice muda com essa nova cidade: começa a trabalhar e a ter uma atividade profissional que lhe possibilitará manter e desenvolver novas relações de amizade, garantindo passeios, agora não apenas com membros de sua família (como o irmão ou os primos), mas também com colegas do trabalho.

\subsection{O centro da cidade: local de trabalho}

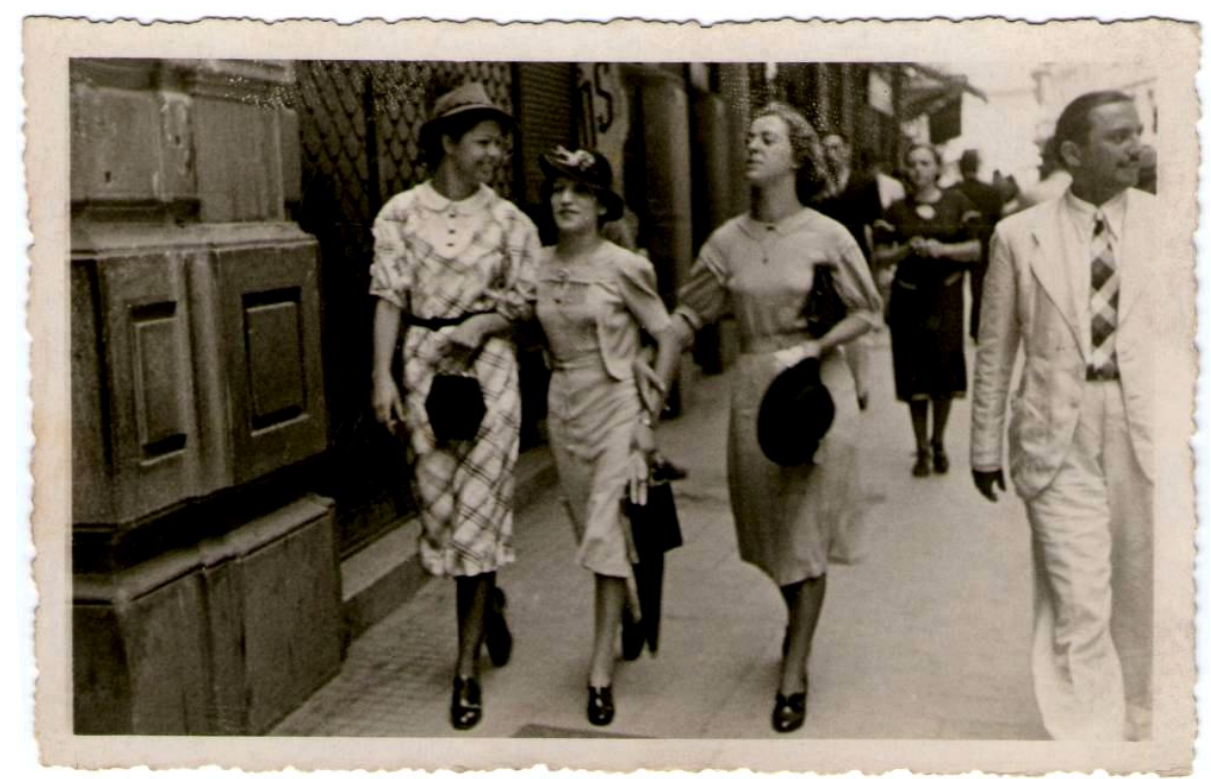

Foto 35: Cleonice à direita, com amigas, segurando o chapéu e aparentemente alheia ao Sr. Conrado José Velloso de Souza Filho que anda à esquerda dela, olhando para além do enquadramento da foto. 1939. Dimensões: 8,5 x 13, $5 \mathrm{~cm}$.

\footnotetext{
${ }^{35}$ Os anos 1950 marcam o início também das preocupações acadêmicas no campo da arquitetura e do urbanismo nascente. A motivação era a metropolização acelerada de São Paulo e é nesse momento também que começam a surgir discussões calorosas sobre o planejamento urbano. Ver a respeito. LEBRET (1951); MELLO (1952, 1954 e 1955); LANGENBUCH (1971); LAMPARELLI (1994).
} 
Desde o início do século XX, uma série de novas atividades profissionais (entre as quais fotógrafos, balconistas, secretárias, recepcionistas, telefonistas e empresários) surgiu com o crescimento da capital paulista, criação histórica do mundo urbano, cuja solidificação liga-se, entre outros fatores, ao processo de expansão e diversificação do aparelho do Estado. Com efeito, como assinalou Frehse, a proclamação da República também viria a favorecer a consolidação histórica da classe média emergente no contexto paulistano (FREHSE, 2004: 39).

A presença dos fotógrafos de estúdio desde a invenção da fotografia e, mais tarde, já em fins do século XIX os "fotógrafos de rua" motivados pela evolução da fotografia instantânea, garantem o acesso a representações visuais dos sujeitos fotografados, um desejo recorrente dessa nova classe média. Com a invenção das câmaras amadoras, os "fotógrafos de rua" produzirão imagens de pessoas pelas ruas das grandes cidades, entre as décadas de 1910 e 1930. Esses fotógrafos da primeira metade do século XX parecem captar toda uma dinâmica específica da vida urbana paulistana. $\mathrm{Na}$ foto 35, feita em 1939, Cleonice parece ter encomendado a um deles uma imagem sua andando com amigas pela zona central da cidade, por ruas que faziam parte do seu trajeto de ida, volta e permanência no centro, onde ela trabalhava. Na coleção $\mathrm{CMH}$, há apenas duas imagens desse tipo (uma, a que mostro abaixo e a outra feita em Santos alguns anos depois).

A tomada é feita em momento de circulação das amigas pelo centro nervoso da capital, então em processo de intensa transformação com a implementação do Plano de Avenidas $^{36}$ do prefeito e urbanista Prestes Maia entre 1938-1945 ${ }^{37}$.

As três andam no mesmo ritmo - pode ter sido uma sugestão do fotógrafo - o que faz com que suas pernas estejam alinhadas sob um mesmo movimento. Na composição, a amiga menor está entre as duas, o que pode ter sido outra recomendação do fotógrafo para compor uma cena equilibrada entre as figuras. $\mathrm{O}$ espaço existente entre Cleonice e o Sr. Conrado José Velloso de Souza Filho - que parece ser apenas um

\footnotetext{
${ }^{36}$ O plano idealizado nos anos 1930 foi parcialmente implantando e consistia basicamente num sistema radio concêntrico de vias para automóveis, associado a um projeto urbanístico cujas principais avenidas conduzem a áreas verdes.

37 Uma breve biografia de Francisco Prestes Maia (1896-1965) está disponível em http://cpdoc.fgv.br/producao/dossies/JK/biografias/prestes_maia Acesso em 13/03/2012. Para a discussão sobre o uso da história da cidade de São Paulo no plano de avenidas consultar: CARPINTÉRO (2007: 111). Ver também MORSE (1954: 299-301).
} 
passante, alheio ao que está ocorrendo - deixa entrever uma mulher de roupa escura que não só anda sem chapéu, mas está sozinha. Seu gesto de mãos parece consciente de que estava sendo fotografada neste momento (ainda que como elemento no cenário), pois a foto de rua termina por captar o dinamismo do espaço coletivo. Se esta figura desperta a atenção é porque acontece aqui o que Barthes chama de punctum, aquilo que dá vida exterior a foto, cujo detalhe, um tanto perdido na composição, faz com que o espectador vá além do motivo principal, no caso, o grupo em primeiro plano (1984: 86).

À exceção da moça situada no meio, ninguém mais olha para a frente; essa diversidade de direções do olhar tem relação com os estímulos nervosos da vida urbana, que, naquele momento, era simbolizada pelo centro. Para onde olhar? A amiga sorridente de Cleonice mira à direita enquanto esta eleva o rosto para o alto fazendo $\mathrm{o}$ jogo da fotografia de rua. A imagem tomada em pleno fluxo urbano sugere terem sido os modelos fotografados sem saber. Não precisam parar para posar para a foto, afinal estão em trânsito. Estão circulando.

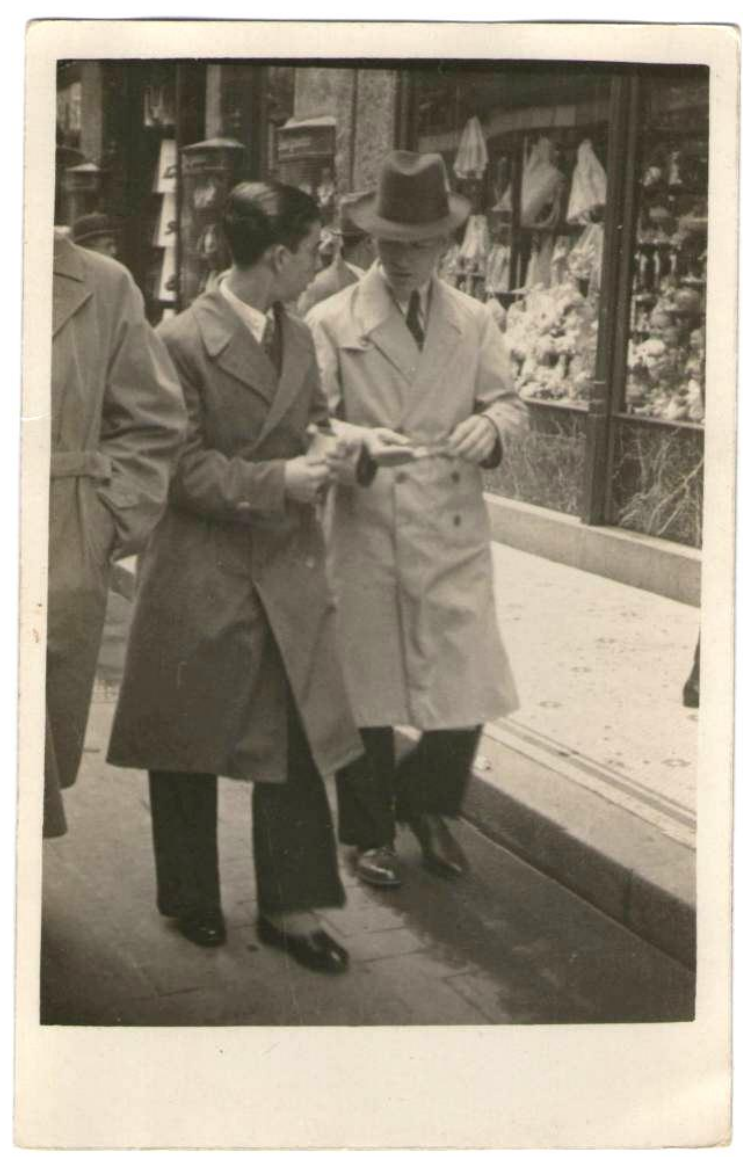

Foto 36: Germano anda no centro ao lado de um amigo anônimo. Fotografia s/d. 
A foto 36, de Germano, mostra atitude semelhante: tal como as amigas e o $\mathrm{Sr}$. Velloso, os modelos não encaram o fotógrafo. Eles andam pela cidade, conversam, os gestos de suas mãos revelam interação social, mas nenhum dos dois encara a câmara; ao contrário, parecem envolvidos consigo mesmos no anonimato da experiência urbana: só eles sabem quem são.

Nesse tipo de fotografia, não há qualquer problema em cortar personagens, como é o caso do homem à direita (cujo ombro direito aparece quase como uma roupa vazia) ou mesmo o corpo do Sr. Souza, também fragmentado à esquerda na foto 35 . Vale à pena observar ainda as diferenças entre ambas as fotos: na de número 35, todos mostram o rosto e andam quase de frente em direção ao fotógrafo. Já na foto 36, é como se o fotógrafo se embrenhasse no meio dos passantes para captar a passagem dos cavalheiros, como se estes fossem pessoas importantes. $\mathrm{O}$ amigo de Germano vive tão bem a personagem urbana que se vira contra a câmara, exibindo antes a nuca que o rosto.

O contraste entre os conteúdos das duas imagens é flagrante: na foto 35 , vemos quatro mulheres transeuntes, enquanto que, na 36, apenas homens. A mobilidade espacial das mulheres nas ruas do centro urbano é fruto de um processo de grandes transformações sociais, decorrentes da organização dos papéis de gênero - sobretudo em função da urbanização e industrialização. Capitaneadas pelo governo do presidente da província João Teodoro (entre 1872 e 1875), pela gestão de Antonio Prado e Barão de Duprat (entre 1889 e 1914) e, mais tarde, pela de Prestes Maia, as rua tornam-se espaços privilegiados das sociabilidades modernas. As relações de trabalho adquirem relevância e acompanham as mudanças físicas e materiais em curso desde a segunda metade do século XIX.

Desde o início até fins do século XIX, a rua é lugar de permanência de pobres, escravos, forros, homens livres nacionais e estrangeiros; os membros das elites por ali só passariam em ocasiões excepcionais como festas religiosas e cívicas (FREHSE, op.cit.36). Tal cenário se mantém relativamente inabalado até o início do século XX. Em relação às mulheres, especificamente as pertencentes às elites, elas só sairão às ruas com maior assiduidade a partir da década de 1920 (idem, 36). A foto 35 é exemplar para pensar a mobilidade das mulheres das camadas médias, pois sabemos que a sua entrada no sistema produtivo dá-se em razão da escolaridade que possuíam, o que lhes permitia realizar tarefas antes restritas aos homens (embora ganhassem menos).

As duas imagens (fotos 35 e 36) têm o mérito adicional de exibirem os 
comportamentos diversos de homens e mulheres na rua; trata-se de exibir-se no trajeto cotidiano associado ao trabalho e à rapidez da vida moderna, na parte mais urbanizada da cidade. Não se cogita nesse contexto a pose diante de um monumento ou prédio importante; a rua pelo qual andam, todavia, não identificada, revela marcas características do centro da cidade: volumes arquitetônicos pronunciados e calçamento urbano (foto 35) e vitrines com mercadorias (foto 36).
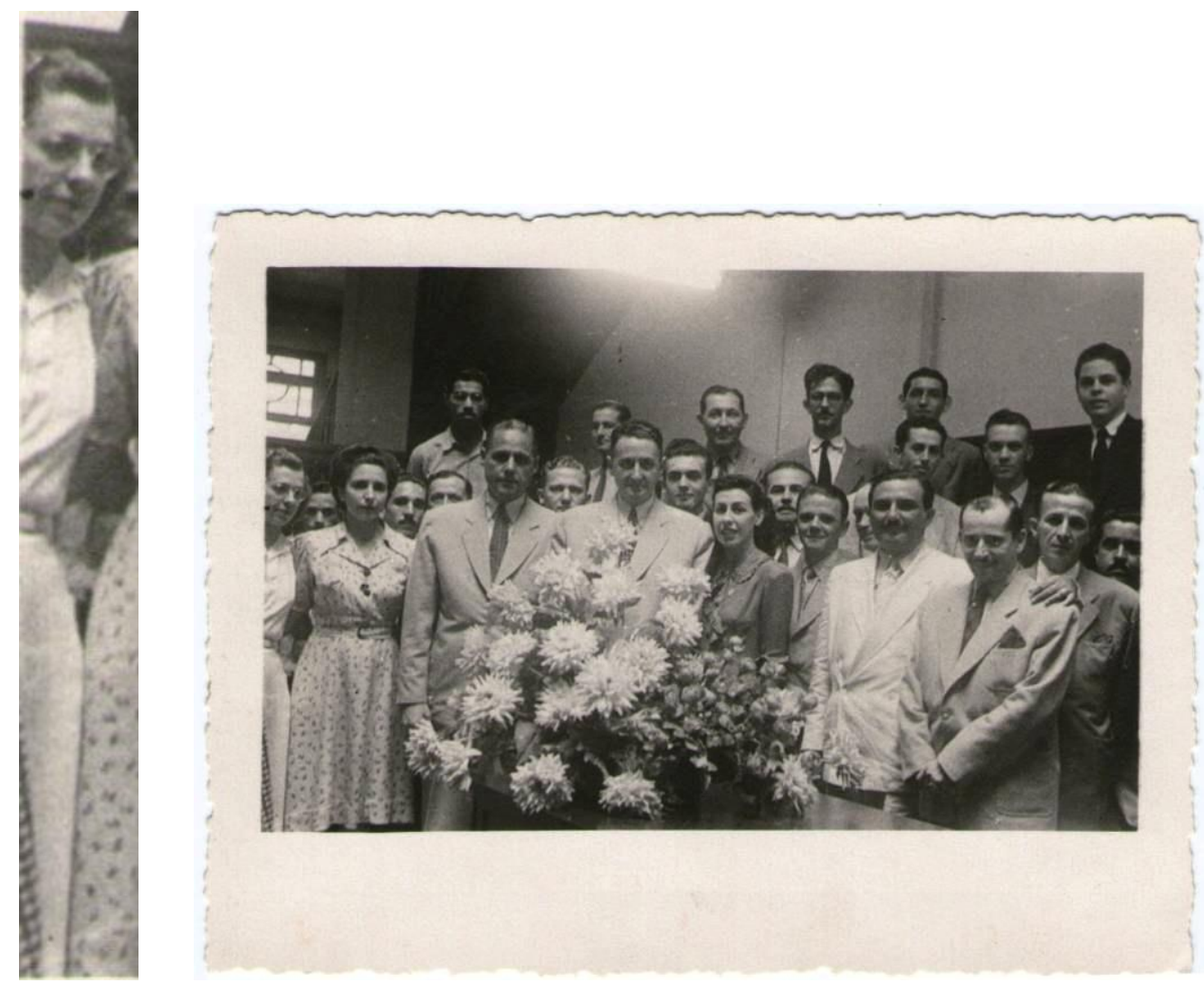

Detalhe 37a e Foto 37: No detalhe, Cleonice no dia da despedida do Sr. Brenn em 30.1.45 na foto maior. Dimensões: 9 x 11,5 cm. Laboratório da FOTOPTICA.

No dia 30 de janeiro de 1945, Cleonice aparece em um retrato coletivo (foto 37), que traz no verso a seguinte legenda: "Lembrança dos colegas da Cia. de Anilinas Prod. Quim. e Material Técnico (dia da despedida do Sr. Brenn)”. A fábrica dessa empresa ficava em Cubatão, mas, creio que Cleonice e o Sr. Souza Filho trabalhavam no escritório da empresa localizado à Rua Brigadeiro Tobias, 388, de acordo com a Revista do Comerciário, $n^{\circ} 32$, de julho de $1959^{38}$. Esta imagem é o registro mais antigo da sua atividade profissional. Ela está à extrema direita da foto o que, por pouco, a tiraria do

\footnotetext{
${ }^{38}$ Acervo GEDES/ SESC Memórias.
} 
retrato: parte significativa de seu corpo foi cortado no enquadramento (como pode ser visto no detalhe 37a). Cleonice e o Sr. Souza, que já se conheciam desde 1939 (foto 35) e ocupavam posições hierarquicamente diferentes na moderna economia de mercado que se atualizava, modernizando antigas desigualdades entre os gêneros. Mulheres realizavam muito bem algumas tarefas masculinas, como a rotina de escritórios, e ganhavam menos por isso desde fins do século XIX.

A companhia em questão, cujo nome antigo era Fábrica de Anilinas e Produtos Químicos do Brasil, construída em 1915, começou a funcionar em 1916. Seu fundador foi J.B. Duarte. Em 1924, ela foi comprada por John Jürgens, empresário alemão instalado no Rio de Janeiro, que representava uma grande firma atacadista alemã de anilinas localizada em Hamburgo. A Alemanha era líder na exportação desses produtos inclusive para o Brasil. A John Jürgens \& Cia. era proprietária, dentre outras, da Cia. de Anilinas de J.B. Duarte e tinha filiais no Rio Grande do Sul, Santa Catarina, São Paulo, Pará e Pernambuco. "No final dos anos 20, a fábrica era a primeira indústria do Estado de São Paulo em força motriz, a segunda em número de operários, que chegavam a 100, e a terceira em capital" (PERALTA, 1979: 83).

Em 1930, a empresa passou a chamar-se Cia. de Anilinas e Produtos Chimicos do Brasil, contando com o suporte técnico de especialistas alemães. Entre fins dos anos 1930 e início dos anos 1940, é que ela passa a denominar-se do modo como figura na legenda de Cleonice. Cleonice pode ter sido útil à empresa porque devia falar e escrever em alemão, e o ambiente necessitava dessa habilidade comunicativa. Em 1945, o Sr. Brenn pode também ter vindo a São Paulo, como um dos especialistas alemães que davam suporte à Cia de Anilinas, e sua permanência talvez tenha motivado a criação da segunda empresa para a qual Cleonice viria a trabalhar, e da qual um dos sócios era o Sr. Conrado José Velloso de Souza Filho. Com efeito, oito meses depois, em 18/9/1945, era fundada a Sociedade Química Brasileira, cujo objeto da atividade, informado pelo site da Jucesp indica apenas "fabricação de produtos químicos não especificados ou classificados" 39 .

A criação da empresa dá-se em um contexto conturbado, seja porque morre o proprietário da Cia. de Anilinas ${ }^{40}$, seja porque as relações Brasil/Alemanha encontravam-se abaladas em razão da entrada do Brasil na Guerra, contra os países do

\footnotetext{
${ }^{39}$ Disponível em: http://www.jucesponline.sp.gov.br/Pre Visualiza.aspx?nire=35206779843\&idproduto= Acesso em 6/2/2012

${ }^{40}$ Jhon Jürgen morre de infarto do miocárdio em 1943 (PINTO, 2009: 21).
} 
Eixo $^{41}$. Embora o clima estivesse tenso para a comunidade germânica e seus descendentes em São Paulo, não há notícias de que a Cia. de Anilinas tenha sido perseguida pela polícia política (DEOPS), como foi a Escola Alemã da Vila Mariana (PINTO, 2009:45).

Se, por um lado, não houve perseguição, por outro, houve retaliação por parte do governo brasileiro quanto à importação de produtos químicos da Alemanha, o que pode ter motivado a criação de empresas nacionais nessa área, como a Sociedade Química Brasileira LTDA.

Cleonice aparece junto aos sócios da empresa nas fotos 38 e 39, três anos após sua fundação.
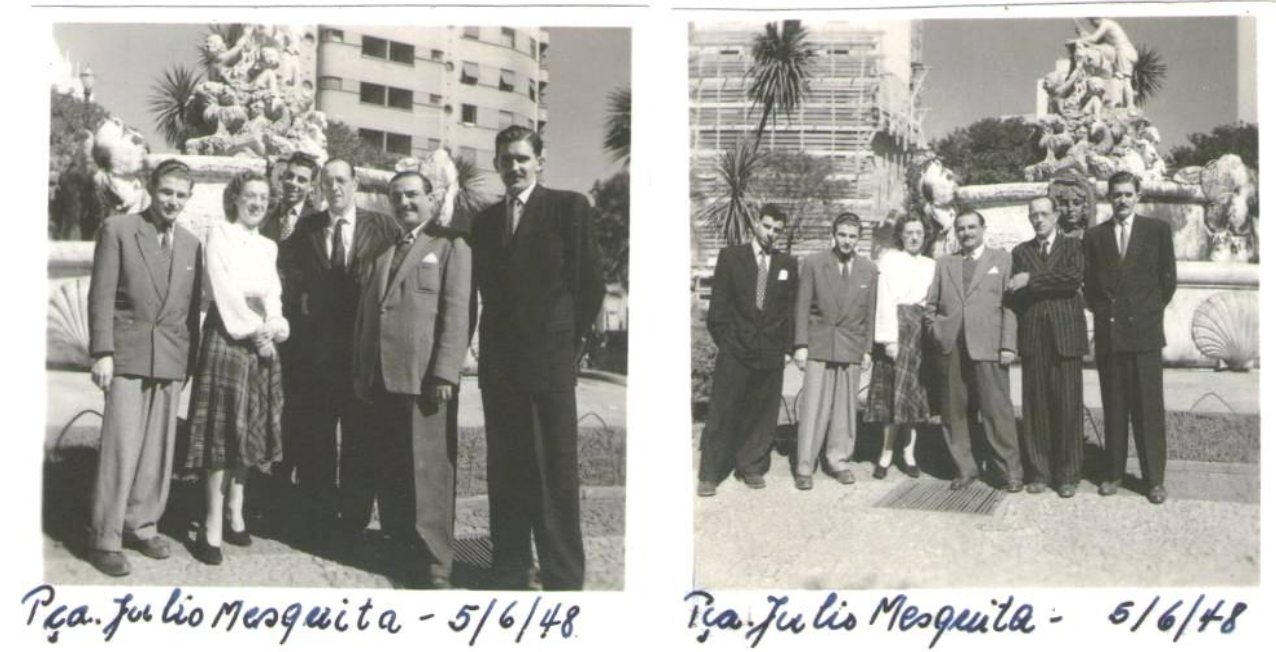

Fotos 38 e 39: Cleonice entre os sócios da Soc. Quim. Bras. na Av. São João 1948. Dimensões: $5,5 \times 6 \mathrm{~cm}$.

O cenário das fotos não poderia ser mais urbano: uma fonte em mármore com detalhes em bronze da escultora paulista, campinense Nicolina Vaz de Assis (18741941) e, ao fundo, prédios construídos ou em construção ${ }^{42}$. Comparativamente, as fotos foram tomadas de diferentes distâncias e em distintas posições espaciais; pode-se notar como o grupo olha ligeiramente para baixo, o que faz com que os prédios atrás deles tendam a verticalizar a cena, especialmente a foto 38, cujo prédio ocupa o centro da composição. Vale observar ainda que as posições escolhidas revelam diferentes aspectos

\footnotetext{
41 Ana Maria Dietrich afirma que, nos anos da Segunda Guerra Mundial (1939-1945), "Pululavam denúncias contra os alemães, algumas das quais com fins escusos, como aquelas de funcionários brasileiros que delatavam colegas alemães para poderem ocupar seus lugares na firma em que trabalhavam" (DIETRICH, 2007: 232).

${ }^{42}$ Esse conjunto escultórico fora encomendado para decorar a Avenida São João em 1923.
} 
da Praça Júlio Mesquita: na foto 38, o prédio ao fundo é o Olido ${ }^{43}$, construído na esquina com a Rua Vitória. Na 39, figura um edifício ainda em construção, porém não identificado, mas que talvez seja o edifício Ocean ${ }^{44}$, do lado oposto do Olido.

Essas imagens dão uma ideia do que era trabalhar e circular no centro de São Paulo, nos anos 1940/50: consistia em fazer parte de um espaço em remodelação constante, momento em que as grandes indústrias vão se distanciando da região, que assume uma feição de "praça central" densamente valorizada pelo comércio e pelos serviços.

Essa fisionomia do centro, que adensava em suas ruas bens, serviços, cultura e lazer em um único lugar, leva a pensar na persistência de um modelo antigo; as melhorias na área central mascaravam, segundo Morse, um modelo perverso de urbanização, que, opondo centro e periferia, relegava à última a distância segregadora em relação ao primeiro (MORSE, 1954: 290). Tal fato era agravado pela política de transportes que então avançava na escolha do rodoviarismo - por meio da circulação de ônibus e carros -, somando-se à especulação imobiliária desenfreada. Morse reconhece, porém, que havia uma "simbiose saudável entre campo e cidade", característica peculiar da capital paulista, que, se bem aproveitada, traria amplos benefícios (idem, 292). Algo dessa simbiose pode ser vista nas fotos $25,26,27,28,29,30,31,32,33$ e 34 .

Como procurei mostrar, o campo próximo ou os arredores rurais eram destinos preferidos nos fins de semana e frequentados por aqueles que buscavam nesses recantos algum descanso da vida laboriosa na cidade, em uma época em que os custos de vida elevados não ofereciam possibilidades de lazer à maior parte da população.

\subsection{O comércio de fotografias}

Era também no centro da cidade que se concentravam historicamente os estúdios e lojas de material fotográfico ${ }^{45}$. Entre as ruas Direita, XV de Novembro, São Bento,

\footnotetext{
${ }^{43}$ Esse prédio fica atualmente localizado no número 1009 da Avenida São João.

${ }^{44}$ Atualmente localizado no número 68 da Praça Júlio Mesquita.

${ }^{45}$ Vivian Volf Krauss vem fazendo em seu mestrado um levantamento da distribuição dos estúdios fotográficos atuantes na década de 1940 em São Paulo. A autora fala em 32 estabelecimentos envolvendo desde produtores de papel e outros produtos fotográficos e químicos, até prestadores de serviços e
} 
São João ${ }^{46}$, Praça Patriarca, Anhangabaú, Conselheiro Crispiniano, Barão de Itapetininga. Um pouco mais distante, mas ainda nas imediações, havia os estabelecimentos nas Ruas da Liberdade ao sul e São Caetano ao norte, respectivamente endereços dos fotógrafos João Alt e Photo Bernardo, Rua São Caetano, $103^{47}$. Esse comércio aparece na coleção $\mathrm{CMH}$, por meio de carimbos impressos no verso das fotos (figura 2) ou de envelopes para armazenar as imagens fotográficas (figuras 4,5 e 6).

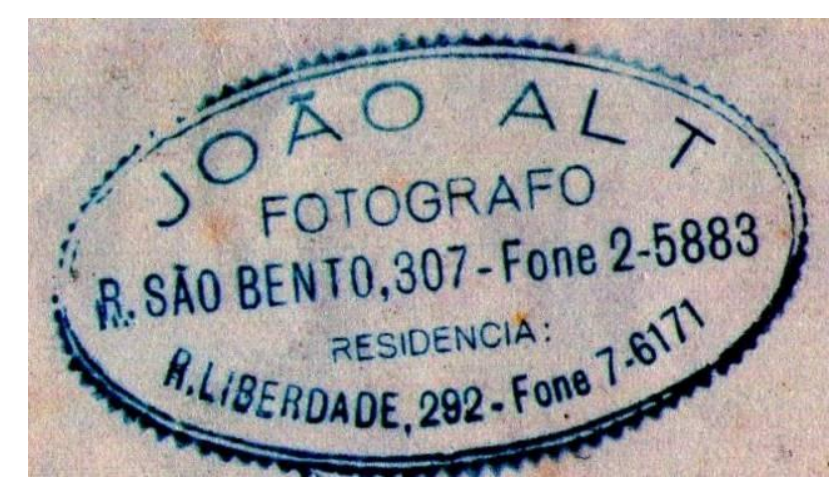

Figura 2: Carimbo de João Alt Fotografo exibido atrás da foto 19.

Com as transformações pelas quais passava a cidade desde 1870, vários estúdios e serviços fotográficos encontravam-se nas ruas: "S. Bento n.27" (estabelecimento "E. Pons e Comp."), "Rua do Carmo, 74" ("Photographia Allemã” de "Carlos Hoenen \& Comp. ${ }^{48 ") ~ o u ~ n a ~ " R u a ~ D i r e i t a ~ 1 ", ~ d e ~ A l b e r t o ~ H e n s c h e l " ~}{ }^{49}$ e Co" (Lima 1991: 64-68). O fotógrafo João Alt, por exemplo, que fez a foto da festa de carnaval da Escola Alemã da Vila Mariana (foto 19), atendia em seu estúdio à Rua São Bento, 307, e em sua residência, à Rua Liberdade, 292. Alexandre, que fotografou duas cenas de um almoço em 1938 no qual estão Cleonice e o Sr. Conrado J.Velloso de Souza Filho, mantinha seu

comerciantes de material óptico. A questão que lhe interessa é saber quais foram as condições que garantiram a consolidação da cultura visual baseada em fotografias nesse período. Ver KRAUSS (2011) e LIMA (2008).

${ }^{46}$ Germano, por exemplo, tem um retrato feito na av. São João 118. Photographo Santhiago.

${ }^{47}$ Kossoy informa que este foi um estabelecimento tradicional em São Paulo, e fotografias de sua autoria são "frequentes nos álbuns de família de representantes da classe média". Bernardo Kohring nasceu nesta cidade em 1894 e faleceu em 1920. A casa, fundada em 1890, funcionou até meados de 1970. Ver (KOSSOY, 2002:193).

${ }^{48}$ Ver sobre este fotógrafo: KOSSOY 2002: 179.

${ }^{49}$ Famoso fotógrafo alemão nascido em 1827, em Berlim, que fundou sua primeira loja em São Paulo em 1882, ano de sua morte. O estabelecimento chamou-se Photographia Imperial. Ver KOSSOY (idem: 175179). 
estúdio à Rua Liberdade, 325, muito próximo de outros estabelecimentos na região como mostra a tabela 1 .

Tabela 1 - Nomes e endereços de fotógrafos, laboratórios e comércio de fotografias 1. Arte Fotográfica Roland (anos 50) R. Sebastião Pereira, 221 - São Paulo - Fone: 52-6975

2. Laboratório Casa Bevilacqua

R: Direita, 13 - São Paulo

3. Cerri - Praça Patriarcha, $8,^{\circ}$ andar. Phone - 2 - 4349 - São Paulo (anos 50)

4. Alexandre - Photographo (anos 30) R. da Liberdade, 325, S. Paulo - Telephone: 7 $-7283$

5. João Alt - Fotographo (anos 40) R. São Bento, 307 - Fone: 2 - 5883; R. São Bento, 307 - Fone: 2 - 5883

6. Marylene Fotografias (anos 50) R. Barão de Itapetininga, 207, 10 andar - Matriz Av. Brigadeiro Luiz Antonio, $1708-1^{\circ}$ andar

7. Papelaria Léo - (anos 40 e 50) R. São Bento, R. Anhangabaú, Avenida. Tiradentes, 8.

8. Photographo Bernardo (anos 30) R. São Caetano, 103.

9. Galerias Fotográficas - Retratista Guilherme Golanda - Edifício Martinelli, 24, São Paulo. (anos 40)

10. Laboratório Fotoptica (anos 40 e 50)

Tabela 1: Nome, endereço e década de funcionamento de estabelecimentos comerciais encontrados na coleção NCW.

Chamam atenção ainda as lojas que comercializavam artigos fotográficos no período (Kosmos, Fotoptica e Papelaria Léo), que foram procurados para revelar as séries fotográficas de passeios de Nelli, tanto na capital quanto no litoral paulista. 


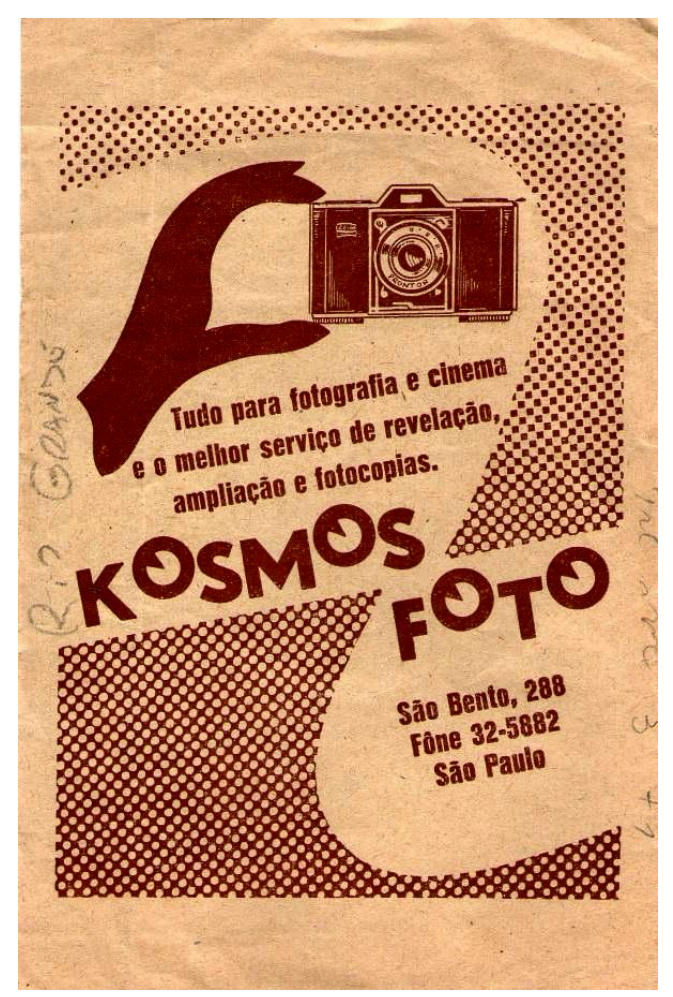

Figura 3: Envelope promocional da empresa Kosmos, circulado em meados dos anos 1940. Coleção GH. Redução das dimensões originais: 9 $x 14 \mathrm{~cm}$

A Kosmos Foto localizava-se à Rua São Bento, 288, e no envelope encontrado na coleção GH (figura 3) consta a seguinte informação: "Seus melhores negativos merecem ampliações especiais em papéis distintos e artísticos. Em papel creme ou rugoso: colorido, sépia ou gravura seu trabalho ficará verdadeira obra de arte". As dimensões da imagem fotográfica, texturas, cores e combinações de papéis são atributos artísticos do tipo de fotografia que a Kosmos fornece a seus clientes. Ao associar o serviço que presta à "obra de arte", ela sugere que os clientes poderiam ser exigentes; indica ainda os meios usados para rivalizar com a concorrência de outras empresas do setor.

Neste envelope há outros dados importantes, entre os quais: tipos de tratamento dados ao papel "margem farpada" (por exemplo, fotos 35 e 37). As cópias, os fabricantes dizem, podem ser feitas em papéis nas cores "semi-mate, branco e creme". O papel é "cartolina com baixo relevo e diversas cores". Na opinião da Kosmos, as imagens assim reveladas "ficam lindas e graciosas". Um dos serviços que a Kosmos presta, como suas concorrentes, é a ampliação. Entre os melhores negativos, podem-se escolher "ampliações especiais em papéis distintos e artísticos". Outra loja especializada, a Fotoptica, tinha um estabelecimento à Rua São Bento, 359, quase 
vizinha à Kosmos, com filial à Rua Conselheiro Crispiniano, 49 (a foto 37 foi revelada pela Fotoptica) Sua estratégia para atrair clientes é semelhante à da Kosmos: ela também associa a fotografia à obra de arte. Porém, a Fotoptica parece ser mais modesta, ressaltando apenas o aspecto artístico de seu produto: "ampliação superfina, um presente artístico e de alto valor". No seu texto, é a ideia de presentear por meio de fotografias que ganha destaque, algo que Cleonice fez com o casal Joana e Germano, ainda que tenha sido também a destinatária de vários desses presentes que circularam ao ritmo da relação afetiva entre primos e amigos. Nesse material secundário (envelopes, papéis de lojas comerciais, embalagens etc.), que parece ter permanecido por acaso na coleção - pois nem todos eles tinham fotografias no seu interior e alguns estavam amassados - surgem dados interessantes sobre o mercado visual de imagens fotográficas; pequenas especializações entre as lojas e diferentes formas de seduzir o consumidor $^{50}$.

O estabelecimento que mais revelou fotografias para Cleonice foi a Papelaria Léo, localizada à Rua Anhangabaú, 89, Rua São Bento 275-276 e Avenida Tiradentes, 8. Da observação do material fornecido pela empresa aos seus clientes podem ser extraídas informações como o tamanho padronizado das ampliações: desde $6 \times 9$, passando pelo formato postal até as dimensões 24 x 30. A Papelaria Léo oferecia ainda revelações em "preto, sépia e azul”, orientando o consumidor para que fizesse a "escolha" certa entre "os melhores negativos". Isso, diz a papelaria, lhe permite fazer "uma ampliação para VER MELHOR”.
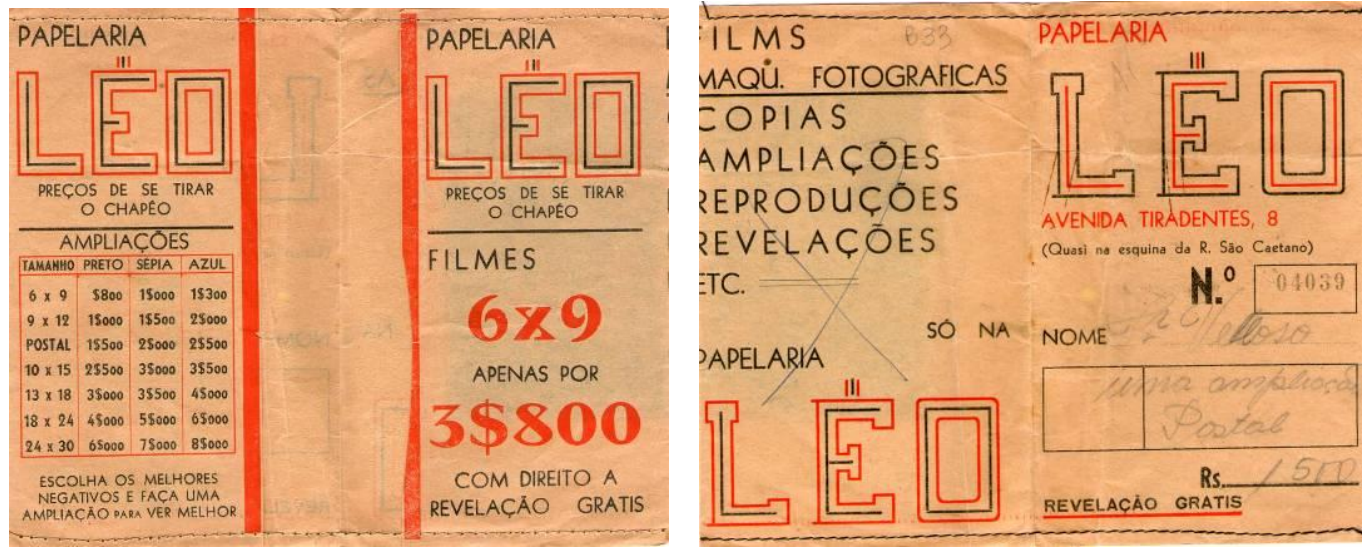

Figura 4: Envelope da Papelaria Léo circulado em meados dos anos 1940 com indicações de tamanhos de revelação, preços e frases de efeito. Redução das dimensões originais: 14,5 $\mathrm{x} 9 \mathrm{~cm}$. 50 O mercado é uma entre outras instituições que assegurariam a existência de um sistema de
comunicação visual em uma sociedade e momento histórico. Ver a propósito KRAUSS (2011: 2928). 
As frases de efeito publicitário para atrair consumidores - como "preços de se tirar o chapéo" ou, ainda, "o amigo dos amadores" - significam, no mínimo, duas coisas: primeiro, essa é uma época em que a moda ainda recomendava o uso de chapéus (ver foto 35 e 36); segundo, a cultura amadora em torno das práticas fotográficas vinha efetivamente crescendo, não só como prática cineclubista ${ }^{51}$, mas também enquanto forma de consumo e circulação de imagens amadoras no âmbito privado das relações familiares. Portanto, para ambas as categorias - de amadores cineclubistas ou privados havia demanda por especialização na prestação de serviços e fornecimento de materiais fotográficos entre os quais máquinas, cópias, ampliações, reproduções, revelações etc.

Desde meados do século XIX, a atividade amadorística começara a se esboçar e a "introdução no mercado das máquinas Eastman Kodak em 1888" favorecerá muito essa atividade (LIMA, 1991:65). A crescente difusão da fotografia amadora mostra que a Papelaria Léo estava atenta e disposta a atender esse público consumidor. Nesse sentido, ela informa: "O nosso laboratório só trabalha com material Agfa" como revela o envelope para guardar negativos (figura 5). Ao indicar essa filiação com os produtos Agfa, a papelaria dizia a seus clientes que vendia, como sugere Ana Maria Mauad, estilo de vida e padrão de qualidade (MAUAD, 2000: 147). Essa empresa alemã fornecia papéis como os tipos: Agfa Lupex, Tropex e Bravira, comumente usados na revelação de fotografias, sobretudo aquelas trazidas por Nelli dos passeios ao litoral realizados a partir de 1941 e reveladas na Papelaria Léo.

\footnotetext{
${ }^{51}$ Veja-se a respeito COSTA \& SILVA (2004). Os autores fazem um levantamento e análise da produção e atuação do Foto Cine Clube Bandeirantes, o surgimento da Escola Paulista de Fotografia, entre outros tópicos como fotojornalismo e práticas amadoras.
} 


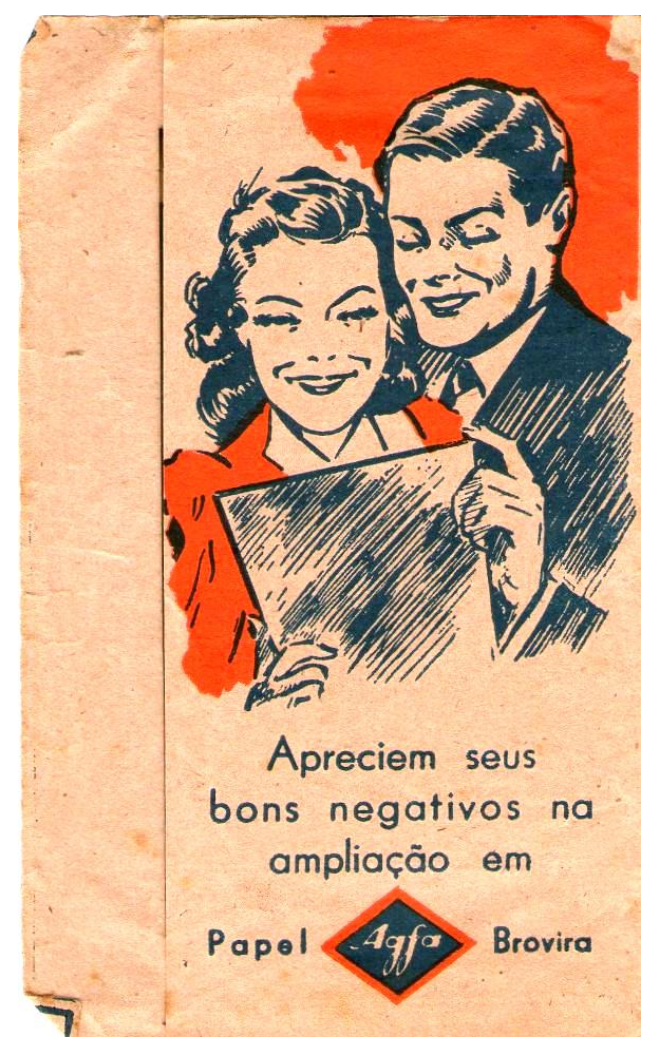

Figura 5: Envelope circulado em meados da década de 1940 com propaganda do Papel Agfa Bravira. Redução das dimensões originais: 8 x $13 \mathrm{~cm}$.

Nada, porém, assinala melhor a relação entre Cleonice e o centro de São Paulo, entre os afetos que a ligavam a sua família e o circuito comercial de venda de produtos fotográficos, que o retrato de seu rosto, único em toda coleção (foto 40). Ela o encomendou ao fotógrafo retratista Guilherme Golanda instalado no Edifício Martinelli, $24^{\circ}$ andar nas "Galerias Fotográficas". 


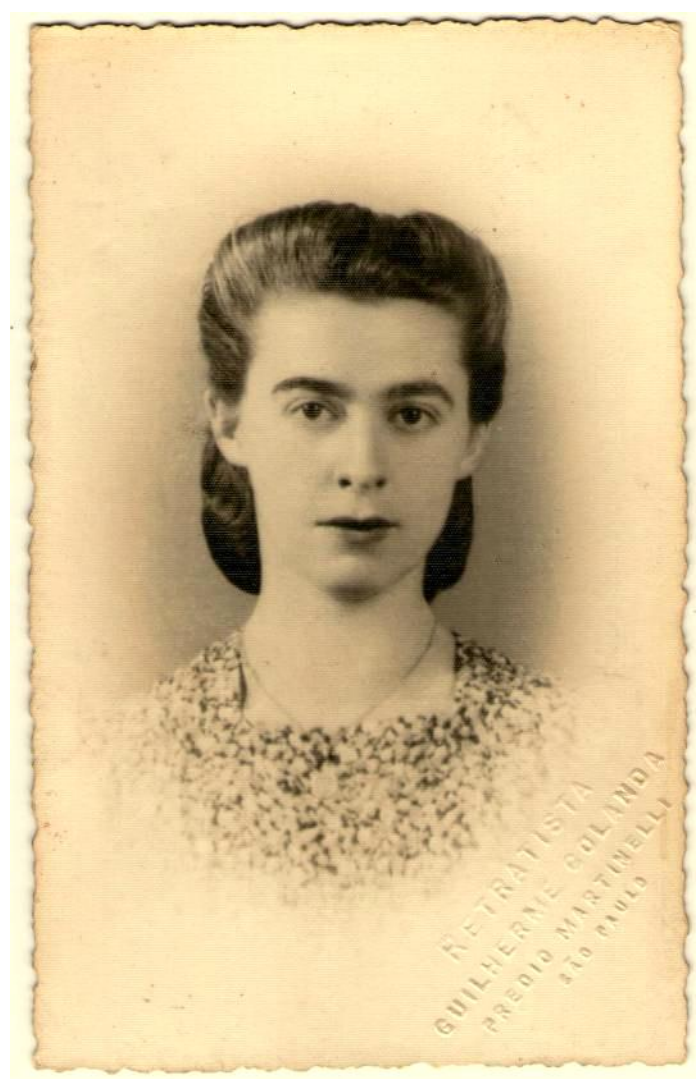

Foto 40: Cleonice em retrato de Guilherme Golanda 1940. Redução das dimensões originais: 8 x $13 \mathrm{~cm}$ e. Papel Wessel. Formato Cartão Postal.

Cleonice tinha então 21 anos e seu retrato - entendido como artefato de comunicação carrega consigo dados sobre a indústria da imagem como o famoso papel Wessel $^{52}$ e dos serviços fotográficos oferecidos na região central. Resultado do que o comércio visual fornecia, o retrato adquirido no Martinelli foi enviado de presente à sua cunhada tal como informa a dedicatória: "Á Laura como lembrança da tua cunhada Cleonice. São Paulo, 8 de julho de 1940”. Dois anos depois, Rosinha (foto 41), irmã de Laura envia-lhe um retrato também adquirido no mesmo retratista. Os recursos visuais utilizados em ambas as fotografias são os mesmos - o sombreado ovalado e tonalizado de sépia e a margem farpada do papel - indicando padrões visuais e materiais em circulação naquela década.

52 Patenteado em 1921, por Ubaldo Conrado Augusto Wessel (1891-1993) os papéis Wessel tiveram enorme aceitação no mercado paulista a partir da revolução paulista de 1924. A instabilidade política trazida por esse episódio impossibilitou aos fornecedores tradicionais abastecerem os fotógrafos. Nesse contexto é que os papéis criados por Conrado começam a ser usados, e passado o período da crise a fama da marca cresce. Em 1936 a empresa já produzia todo o papel fotográfico usado pela Kodak e em 1954 essa última empresa compra a patente Wessel. Uma breve biografia do empresário pode ser conferida em: http://revistapesquisa2.fapesp.br/?art=4268\&bd=1\&pg=1\&lg= Acesso em 18/09/2012. 


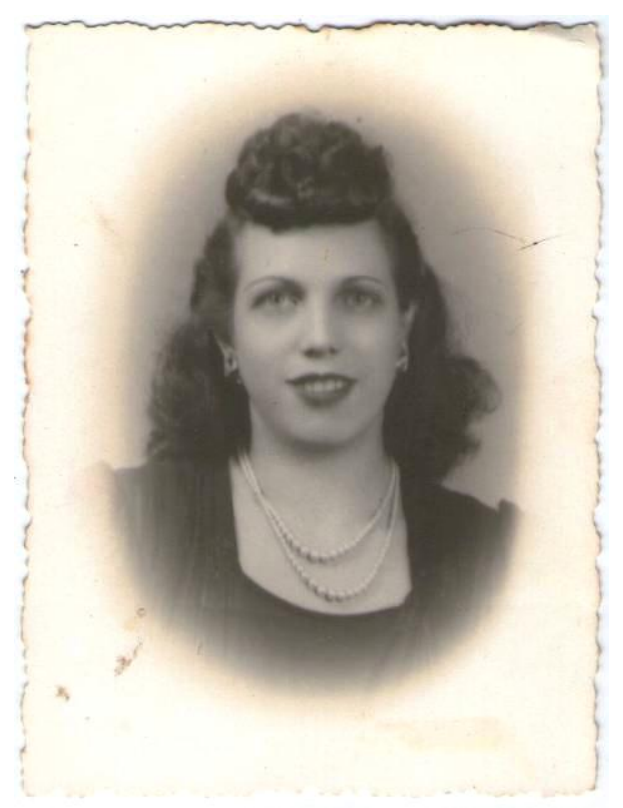

Foto 41: Rosinha irmã de Laura retratada por Guilherme Golanda em foto dedicada ao casal Heine em 1942. Dimensões: 6 x 8 cm.

Esses rostos fotografados no coração da cidade para serem contemplados por familiares são, como diz Ítalo Calvino, "um produto social, histórico, contém mais verdade do que qualquer imagem que se pretenda verdadeira" (1992:58). Por meio deles, emerge tanto a subjetividade dos retratados (afinal trata-se de suas faces), quanto suas relações emocionais de sociabilidade e afeto, motivo pelo qual muitos desses retratos eram feitos.

A escolha pelo retratista Guilherme Golanda, considerando o local onde estava seu estúdio, não foi por certo aleatória, pois, como já visto, o circuito comercial estava bastante aquecido nesse momento e o Martinelli era no início da década de $40 \mathrm{um}$ edifício de grande importância no cenário urbano. A função do comércio visual era assegurar por meio da venda de retratos o desejo de autorrepresentação de indivíduos e grupos que, como Cleonice, desejavam cada vez mais contemplar a sua própria imagem e a de seus entes queridos. Nestes retratos os temas da família e da cidade se encontram e aquilo que é vendido e consumido no circuito comercial da fotografia produz o circuito de trocas afetivas, aproxima pessoas e reafirma seus laços. 


\subsection{Dois aniversários e uma morte}

"A cidade ficou embandeirada o ano inteiro."

Jorge Americano (1963:176)

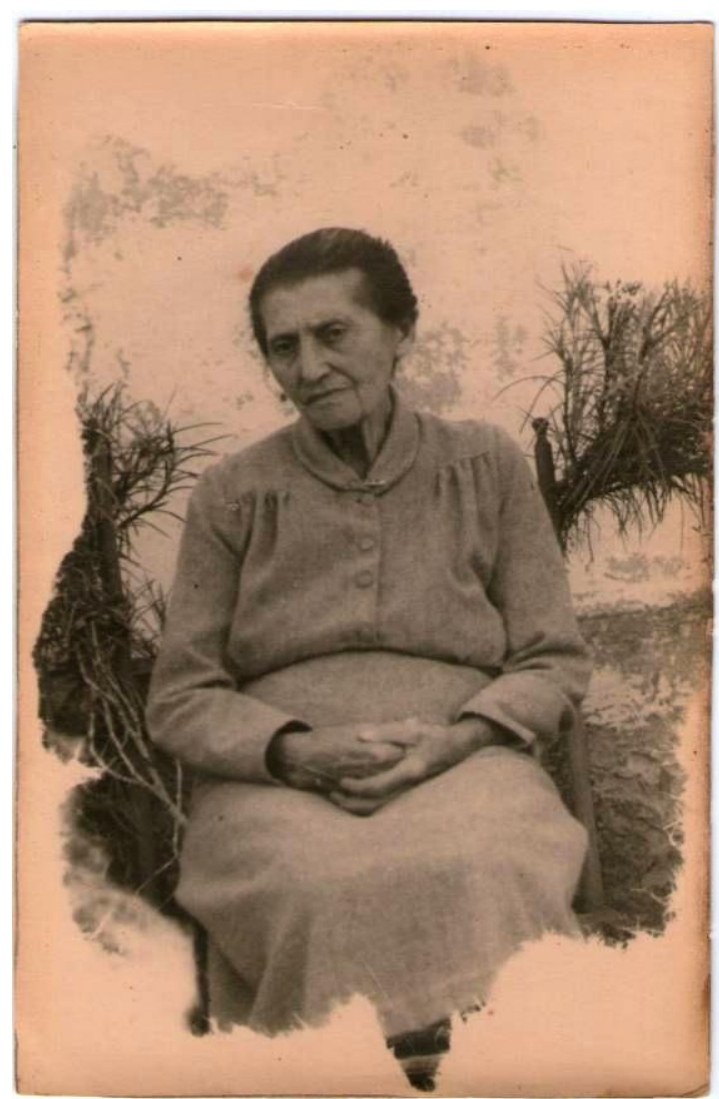

Foto 42: Último retrato de Dona Ida Heine, 1954. Redução das dimensões originais: 9 x $14 \mathrm{~cm}$. Papel Leonar.

Em 5 de outubro de 1954, Cleonice ofereceu a Germano, no dia do aniversário deste, a foto 42. "Ao Germano ofereço como lembrança, pela passagem do teu aniversário, a última fotografia de nossa inesquecível mãe”, diz ela na dedicatória feita ao irmão. É a primeira e última referência direta à morte de alguém na coleção $\mathrm{CMH}$, cuja imagem fantasmática qualifica a ausência da pessoa representada. A fotografia cumpria nessa ocasião o papel de relembrar alguém que já não mais existia, mas cujo retrato organizava a memória dos vínculos familiares e continuava a circular.

Esta mesma imagem funciona como objeto de decoração: na fotografia 43, ela encontra-se sobre uma cristaleira, na sala de jantar, emoldurada em um porta-retratos 
duplo (foto 43 e detalhe 43 a), dividindo o espaço do móvel com uma santa ceia, castiçais, flores e um ventilador. O interessante aqui é notar o circuito restrito, baseado no contato afetivo e emocional com a imagem de um parente. A foto participa do funcionamento da casa como um objeto de culto da memória, função social comum à fotografia de família, no qual aqueles que já morreram permanecem presentes na imagem, que nada mais é do que a máscara que revela e esconde sua extinção inexorável.

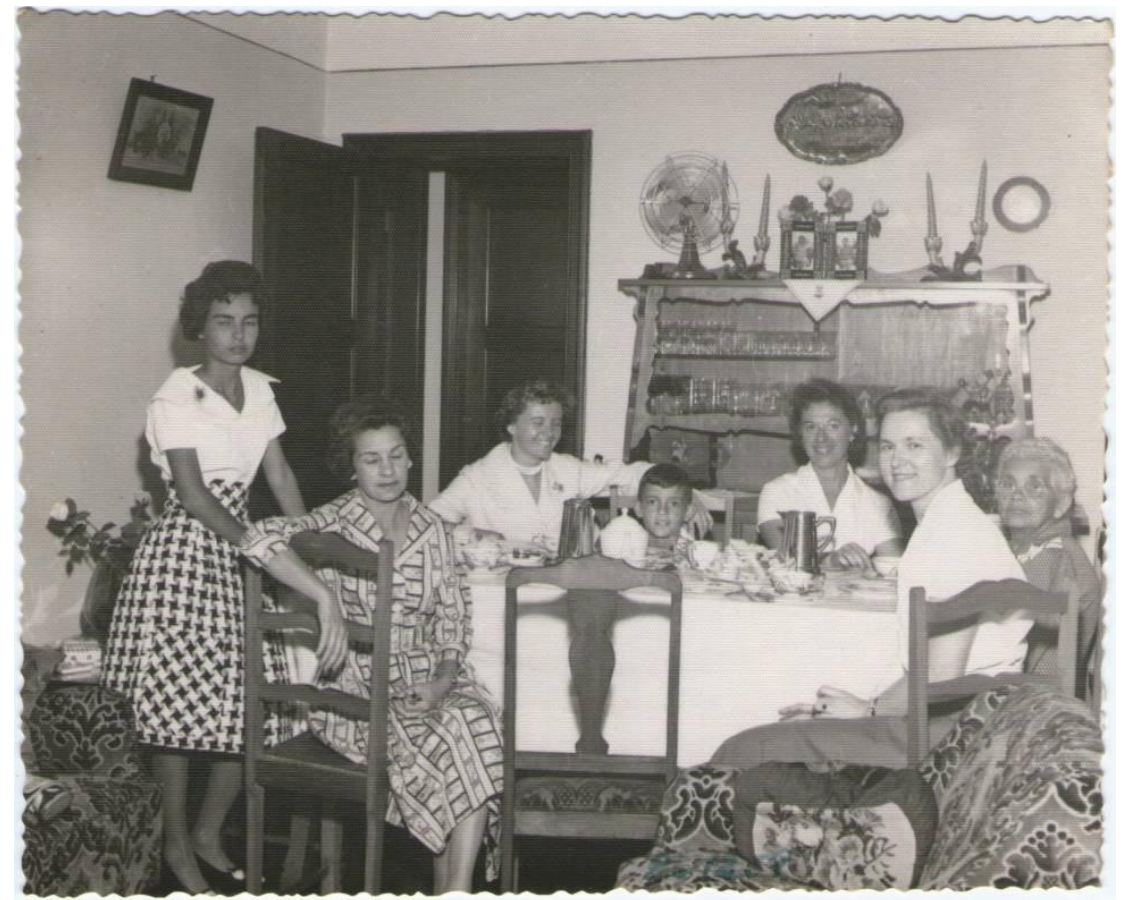

Foto 43: Uma casa não identificada, talvez a residência de Cleonice. Dircinha e Dona Olga em primeiro plano não tiveram tempo de elaborar a pose. Cleonice ao fundo normalmente atenta, sorri para a câmara. S/D. Ampliação das dimensões originais: 11 x 13, 5 cm.

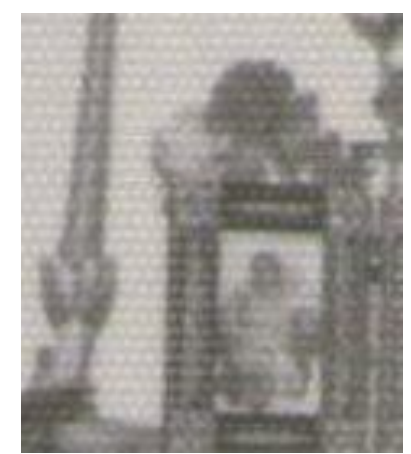

Detalhe 43a: Porta-retratos sobre o móvel da sala de jantar.

Morria sua mãe, aniversariava seu irmão e a cidade celebrava seus 400 anos. $\mathrm{O}$ elemento comum entre tais eventos é a fotografia, recurso capaz de comunicar 
diferentes experiências e situações sociais. O Quarto centenário da cidade de São Paulo mobilizou muitas pessoas, que confluíram para as ruas do centro da cidade, inclusive Cleonice, Dircinha, Dona Amelina (sobre a qual nada sei), um jovem anônimo e o Sr. Conrado J. Velloso de Souza Filho, o fotógrafo. O grupo foi apreciar o evento organizado pela comissão do IV Centenário ${ }^{53}$.

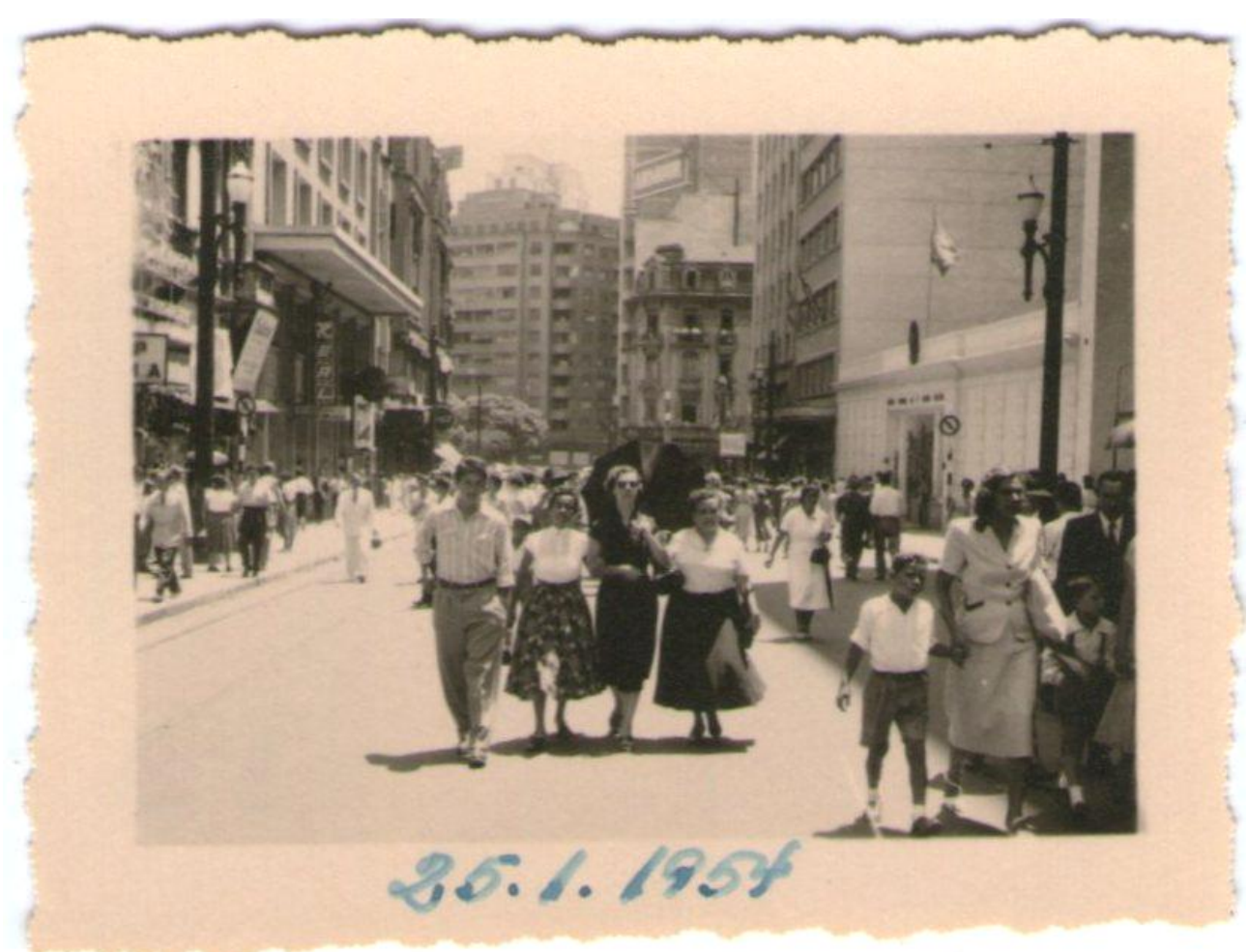

Foto 44: Cleonice de preto tendo à sua direita Dircinha e anônimo e, à esquerda, Dona Amelina. Ampliação das dimensões originais: 6,5 x 5, $5 \mathrm{~cm}$.

$\mathrm{Na}$ foto 44, Cleonice define-se em relação ao grupo pelos elementos escuros: óculos e vestido. O fotógrafo posiciona-se na frente do grupo para enquadrá-lo no centro da imagem, fora da faixa de sombra à direita, tendo ao fundo o Largo do Paissandu. Há várias pessoas na rua e muitas delas se dirigem ao Vale do Anhangabaú, já que parte das celebrações ocorrerá ali. Nessa ocasião festiva, a rua, lugar

\footnotetext{
${ }^{53}$ A comissão foi criada inicialmente na gestão do Prefeito Paulo Lauro (1908-1983) em 1948 foram nomeados Fábio da Silva Prado, Armando de Arruda Pereira, Lineu Prestes, Nicolau Tuma. Porém a comissão organizadora dos festejos relativos aos 400 anos da cidade de São Paulo sofreu várias mudanças. Foi só em 1951com o então Prefeito Armando de Arruda Pereira (1889-1955), que a comissão agora composta por sete membros, deu inicio aos trabalhos. Ver texto completo em: http://www.prefeitura.sp.gov.br/cidade/upload/fundos_documentais_1255023339.pdf acesso em 03/09/2012
} 
tradicionalmente destinado ao fluxo, torna-se excepcional espaço de "fruição" em razão da festa coletiva (MAGNANI, 2009: 2).

Impossível não lembrar as fotos 35 e 36, mas ao contrário destas, as personagens agora não só estão mais distantes, como há maior profundidade de campo, o que permite ver um trecho de céu em meio à arquitetura verticalizada da rua.

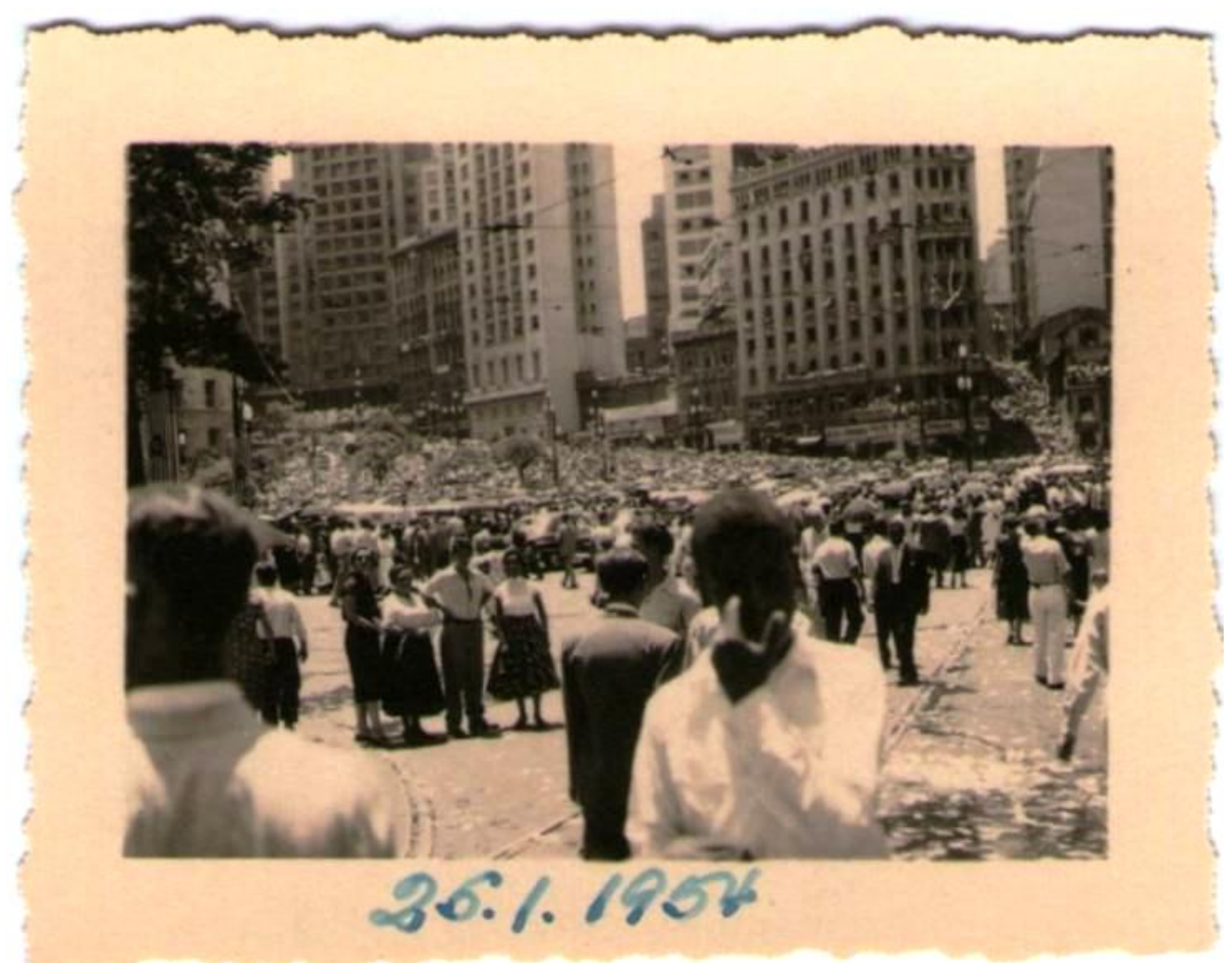

Foto 45: Cleonice à esquerda de vestido e óculos escuros ao lado de Dona Amelina, rapaz anônimo e Dircinha. Ampliação das dimensões originais: 6, 5 x 5, 5. Papel Leonar.

A foto 45 mostra o grupo já no Vale do Anhangabaú, um pouco afastado da multidão, em uma área em que a verticalização iniciada com o edifício Martinelli estava já consolidada e não se resumia apenas ao seu entorno imediato ${ }^{54}$. Comparativamente ao que mostra a foto 35, a cidade agora é outra; outros também são os personagens fotografados. Dos presentes naquela foto, restaram Cleonice e o Sr. Souza, que, agora, é o fotógrafo. $\mathrm{Na}$ foto 45 , o primeiro plano é desfocado tanto à direita (com o menino negro de frente), quanto à esquerda (com o homem de costas). $\mathrm{O}$ grupo ocupa à

\footnotetext{
${ }^{54}$ Segundo o entusiasmado geógrafo Aroldo de Azevedo, esse lugar "Deixou de ser a cidade acachapada dos idos de 1920, quando possuía $70 \%$ de edifícios térreos, para tornar-se a cidade dos arranha-céus, com uma "sky-line" que se alteia, em impressionante perfil, por mais de 5km, estendendo-se desde o Brás até Higienópolis, de Santa Efigênia até à Avenida Paulista" (1961: 43).
} 
distância o espaço entre as duas figuras. O primeiro plano foi intencionalmente usado para ressaltar as figuras agrupadas em segundo plano, sendo o contato com estranhos neste caso, homens negros ligados ao setor popular - característico de uma cidade que se tornou uma "grande encruzilhada do Brasil e do mundo" (AZEVEDO, 1961: 43). Tal estratégia compositiva do fotógrafo mostra que nem sempre o primeiro plano é reservado ao tema mais importante em uma foto; ao contrário, ele pode mesmo servir para ressaltar o segundo plano. Ao observarmos ainda o solo na foto acima, é possível ver as marcas dos trilhos dos bondes elétricos que, mesmo com a criação da CMTC em 1947, ainda garantiam parte do transporte entre os bairros e o centro ${ }^{55}$.

Nessa ocasião, a cidade celebrava o seu crescimento e sua transformação estrutural. O centro demonstrava como São Paulo havia se tornado algo além de uma Chicago dos trópicos (LÉVI-STRAUSS, 1996: 36). Na época, a Editora Abril publicou uma revista especial para cobrir tais acontecimentos. A reportagem destaca a vida desgastante de labuta e "testa vincada", fruto de um dia a dia exaustivo, segundo deixa entrever o texto, para os paulistanos levarem às ruas da cidade todo seu "entusiasmo" em viver e tirar seu sustento da cidade "que mais cresce no mundo" 56.

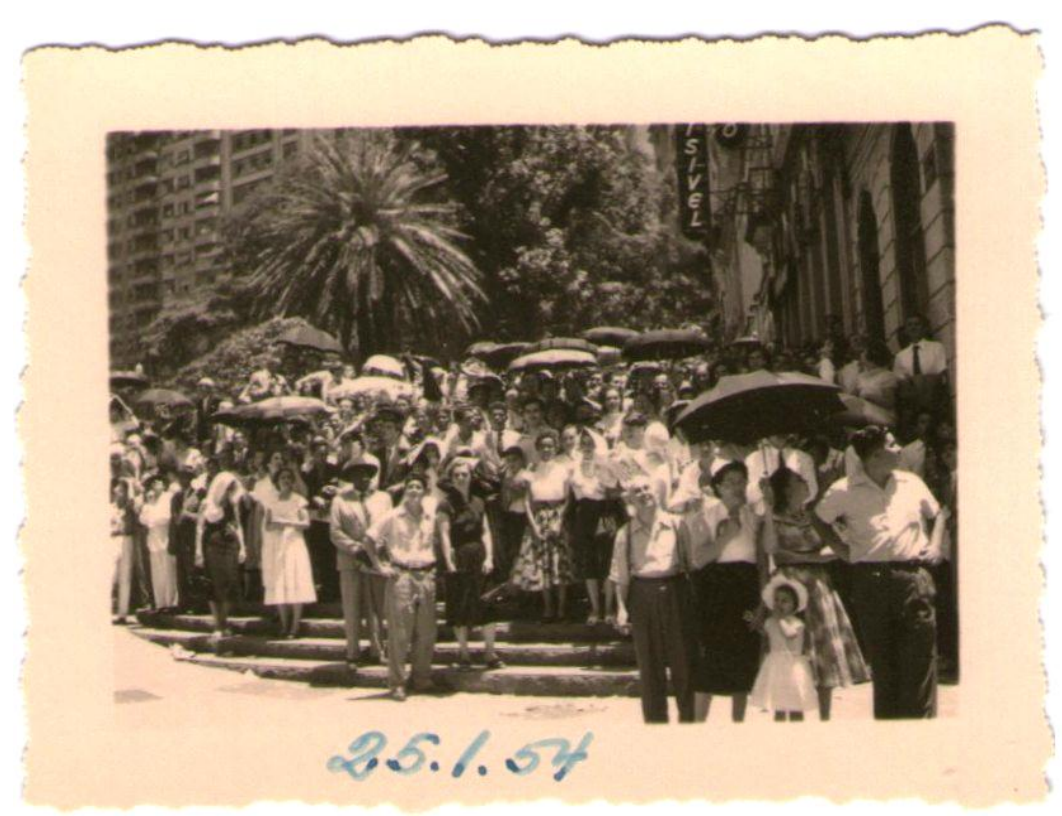

Foto 46: Cleonice no Centro de São Paulo nas comemorações do IV Centenário, 1954. Ampliação das dimensões originais: 6,5 x 5,5 cm. Papel Leonar.

\footnotetext{
55 Até "1949 os bondes transportavam mais passageiros que os ônibus" desta empresa. A situação invertese apenas a partir de 1951, acentuando o "congestionamento" dessa região da cidade (INOUE, 2011: 175).

${ }^{56}$ No texto, o editor cria um elo entre o passado e o presente, entre Anchieta, Nóbrega e os 3 milhões de paulistanos da época. O texto completo está disponível em: http://www.labjor.unicamp.br/patrimonio/materia.php?id=139 Acesso em 24/5/2012.
} 
$\mathrm{Na}$ coleção $\mathrm{CMH}$, as fotografias restantes da presença do grupo nas celebrações nada têm de celebratório, parecendo mesmo que a ida ao aniversário de 400 anos da cidade era só mais um passeio, mais uma oportunidade de exercício de sociabilidade, um motivo a mais para se fazer registros fotográficos. Suponho que Dona Amelina, talvez parente do Sr. Souza Fillho, estivesse passando uma temporada em São Paulo, pois, no mês de fevereiro, ela aparece ao lado de Cleonice, do rapaz anônimo (das fotos 44,45 e 46) e do Sr. Souza Filho no aeroporto de Congonhas ${ }^{57}$.

Finalmente, a última imagem desse passeio (fotos 46 e detalhe 46 a) revela um acontecimento constantemente relatado por aqueles que, como o cronista Jorge Americano, acompanharam as comemorações dos 400 anos. Algumas pessoas olham para o alto, o que não acontece com Cleonice, Dircinha e Dona Amelina que miram a câmara. É possível que elas estejam observando os "papeluchos prateados que brilhavam ao sol" e que foram lançados por aviões (AMERICANO, 1963: 175).

À exceção do jovem ao lado de Cleonice, Dircinha, Dona Amelina e Cleonice parecem estar mais preocupadas em "sairem bem" na foto, mantendo a comunicação, ainda que em meio a muita gente, com o fotógrafo.

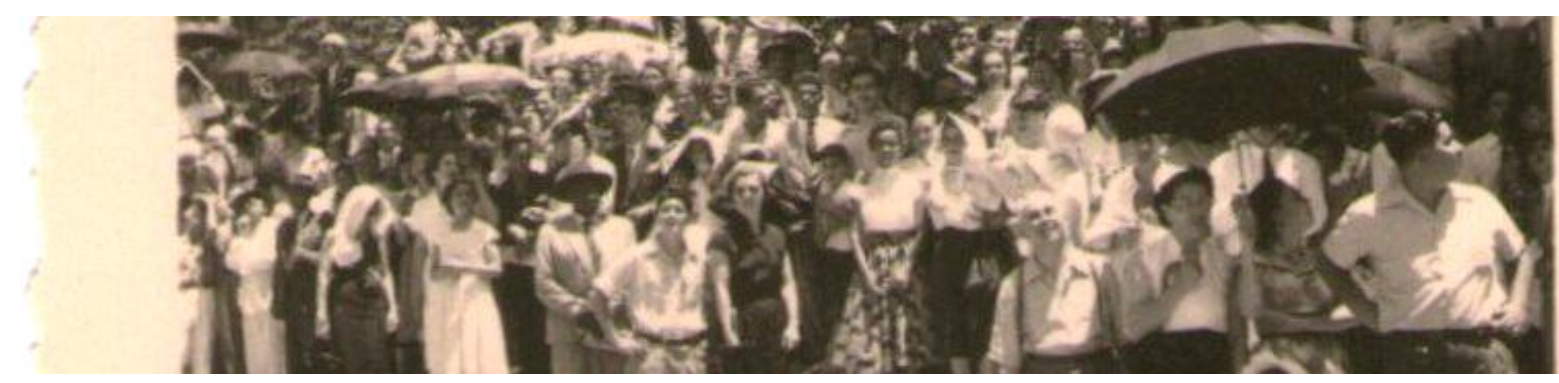

Detalhe 46a: Detalhe onde aparecem Cleonice e à esquerda um acompanhante anônimo. Um pouco acima à direita estão Dircinha e Dona Amelina. Ampliação das dimensões originais: 6,5 x 5,5 cm.

Procurei no presente capítulo contar a história de Cleonice Maria Heine a partir de um arranjo que fiz de parte de suas fotografias. De fato tais fotografias que circulavam como objetos de comunicação que são e produzem subjetividades,

\footnotetext{
${ }^{57}$ Carvalho \& Lima, na análise que fazem dos álbuns fotográficos de São Paulo entre fins do século XIX e a década de 1950, afirmam que entrou em circulação nesse momento um calendário com imagens de lugares considerados importantes, entre os quais figurava o aeroporto de Congonhas. (1997: 25).
} 
ressaltaram o ponto de vista da própria Cleonice que, ao guardar imagens de si mesma, nos legou práticas e representações da cidade que viu florescer sua experiência única.

Dois conjuntos de fotos foram montados pela aproximação de itens aparentemente sem relação uns com os outros, em função de um duplo movimento: um primeiro cuja melhor expressão é a noção de circuito afetivo tem a ver com a história de sua família e com o início de sua socialização através de imagens fotográficas. $\mathrm{O}$ segundo, que chamei de "circuito comercial", apenas complementou o primeiro.

Verificamos, portanto, que o papel de produzir sociabilidades, relações sociais com a família, os amigos e o trabalho coube a fotografia. Como veremos nos dois próximos capítulos é a partir desses laços ampliados de relações extra-familiares, que Cleonice fará muitos passeios ao litoral e ao interior de São Paulo. 


\section{Capítulo 2: Mapas de deslocamentos: turismo na praia}

O direcionamento do olhar do turista implica frequentemente diferentes formas de padrões sociais, com uma sensibilidade voltada para os elementos visuais da paisagem do campo e da cidade, muito maior do que aquela que é encontrada normalmente na vida cotidiana. As pessoas se deixam ficar presas a esse olhar, que então é visualmente objetificado ou capturado através de fotos, cartões postais, filmes, modelos, etc. Eles possibilitam ao olhar ser reproduzido e recapturado incessantemente John Urry (1999: 18).

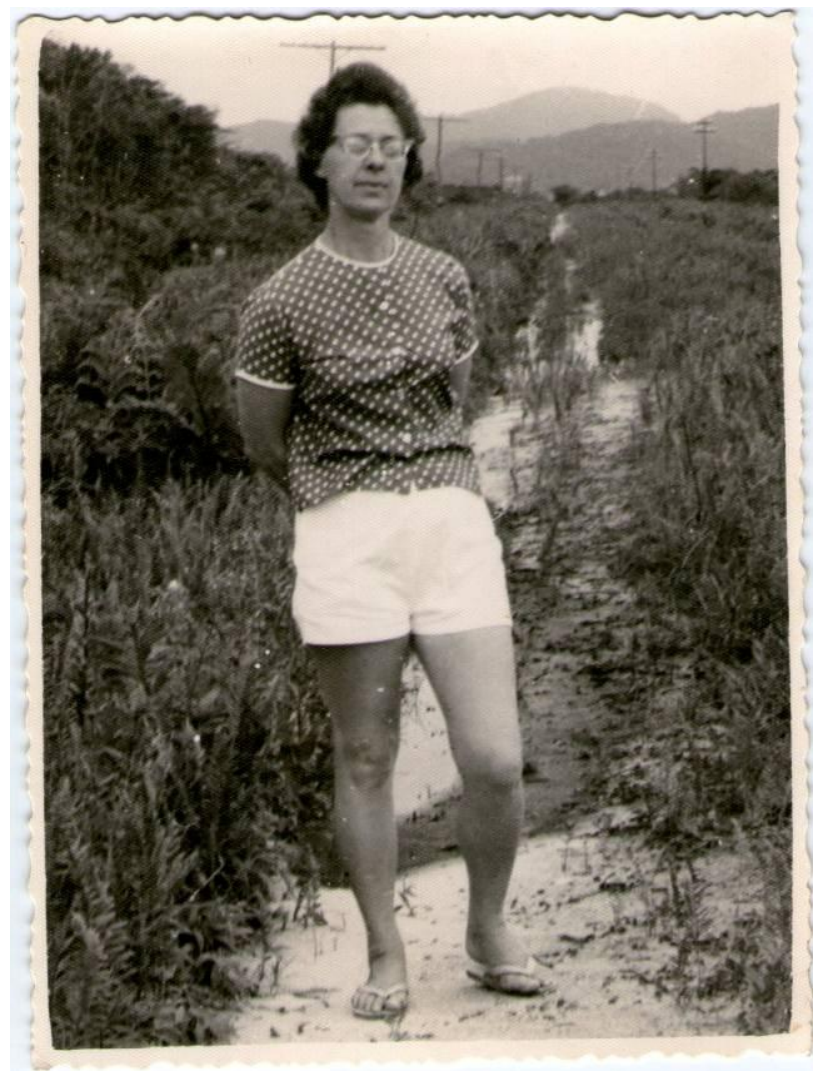

Foto 47: Cleonice, S/D no litoral de São Paulo. S/D. Dimensões 11 X 8 cm. No verso está impressa a frase: "A fotografia é o passado no presente e a reminiscência no futuro".

Esta imagem que abre o capítulo mostra Cleonice por volta dos anos 50 em um ambiente que ela começou a frequentar ainda criança. A praia suscitou desde sua infância, um interesse fotográfico: inicialmente a orla da praia, mais tarde aparecem, 
dada a intensidade da frequência, trechos da estrada que saía do planalto e levava ao mar, recantos pitorescos, monumentos comemorativos, ruínas de antigas construções e, mais raramente moradores dos lugares visitados. Esse feixe de aspectos registrados no papel, fotográfico tornaram-se, com a passagem dos anos, elementos constituintes da fotobiografia de Cleonice. Ir à praia tornou-se uma atividade costumeira. Na foto 47 , sua figura ereta posicionada no centro da imagem estrutura a composição. $O$ congelamento de seus passos permite descobrir a paisagem: uma trilha estreita de areia que sulca o mato crescente. Há também postes de energia elétrica, artefatos indicativos das transformações do local, motivadas pela comunicação com o planalto. Ao fundo, as montanhas da Serra do Mar quebram a verticalidade do formato da foto. O chinelo de dedo e a roupa básica indicam a intimidade com que muitas vezes Cleonice pisou o solo litorâneo. Neste instantâneo, ela já não era mais tão jovem.

Acompanho agora seus passos nesse ambiente cujas datas-limite dos documentos oscilam entre 1927 e 1963. Nos anos 1960, ao mesmo tempo em que , a atitude colecionista definha percebe-se nas fotos, a massificação do turismo litorâneo, ligada às condições de transporte e à crescente, comunicação entre o planalto e o litoral. Já na segunda metade da década de 1940, com o surgimento da Rodovia Anchieta e da ampliação do acesso ao carro particular, a circulação de bens, produtos, serviços, pessoas e símbolos entre a capital paulista e seus arredores aumentou gradativamente.

A diminuição das fotografias de passeios à praia já a partir de meados dos anos 1950 pode ser atribuída, e isso é uma hipótese em parte verificável, à compra da segunda residência em Cidade Ocian, bairro de Praia Grande, em 1957. Essa aquisição tornou o litoral uma realidade mais prosaica, perdendo, portanto, seu caráter de destino excepcional, reservado em princípio reservado aos fins de semana, feriados e férias. Com efeito, o ocaso dos deslocamentos para esse e outros destinos de recreação, lazer e turismo possivelmente mantém relação com o envelhecimento de Cleonice que, em 1963, tinha 43 anos. Seria necessário investigar os efeitos de pertencer a esse grupo etário naquela década, tarefa que, nos limites desta pesquisa, não é possível realizar.

A relação de Cleonice com a família Souza implica que este e o próximo capítulo se afigurem baseados na dicotomia lazer/trabalho, baliza fundamental para compreender a quantidade de passeios. Tratarei ainda neste capítulo do descanso por temporada, cujas condições de realização se mostram ligadas ao crescimento da indústria paulista e ao surgimento de um cultura urbana que valorizava os passeios e viagens turísticas. 
Cleonice tornou-se "comerciária",58, e esta condição franqueou-lhe o direito de usufruir das instalações do SESC Bertioga (Colônia Ruy Fonseca) ${ }^{59}$ em 1952 e, mais tarde, em 1959. Sua condição de trabalhadora lhe permitiu sair da cidade de São Paulo em busca de repouso e lazer, para recuperar as energias gastas no trabalho que exercia na capital. Essa "fuga" de uma grande cidade como São Paulo para os arredores litorâneos configura-se, ainda hoje, em um movimento pendular entre o litoral e a capital; foi esse movimento de vaivém, de circulação e comunicação que favoreceu a intensa exploração imobiliária de cidades como Santos, Guarujá, Praia Grande e Itanhaém (SILVA, 2003:60).

A transformação do litoral em destino de recreação gerador de riquezas e atração de capital financeiro tem relação direta com a vida econômica da capital paulista, que foi se configurando desde fins do século XIX. Cidades balneárias surgiram, pois, para atender a essa categoria nova de transeuntes - os turistas - que fugiam do planalto em busca de sol, mar, calor e paisagens pitorescas.

O desempenho econômico da cidade de São Paulo financiado pelo capital do café do oeste paulista exerce impacto sobre o processo de crescimento e urbanização do entorno costeiro; em decorrência disso, acaba havendo uma integração entre metrópole e litoral (VIEIRA, 2008; SABINO, 2007; AFONSO, 2006; SILVA, 2003; LANNA, 1996; SEABRA, 1979). Pode-se afirmar que uma parte do capital financeiro produzido na metrópole é investido no litoral em atividades de veraneio, que envolvem infraestrutura urbana, transporte, serviços hoteleiros, lazer, diversão e, consequentemente, a construção de empreendimentos imobiliários de segunda residência $^{60}$ para as camadas médias urbanas, fenômeno verificado na coleção $\mathrm{CMH}$ apenas nos anos 1950.

Embora a relação entre a metrópole e o litoral date de longo tempo, sua intensificação só se dá quando da substituição do transporte ferroviário pelo transporte de bens, serviços e pessoas por rodovias asfaltadas que farão surgir novos critérios de valorização do espaço da praia, objeto de intensa especulação do mercado imobiliário.

\footnotetext{
${ }^{58} \mathrm{O}$ termo é usado pelo SESC desde o momento de sua fundação para referir-se à "laboriosa categoria de trabalhadores", como informa a Revista O Sesc em Marcha - ano 1 , novembro $n 1^{\circ}$ - 1949 . Por conseguinte, a palavra se opõe a comerciante. Ambos (como mostra outro texto publicado no mesmo volume da revista) são "cidadãos" que "dedicam a sua atividade ao engrandecimento econômico do Brasil” (p.1). Acervo GEDES/SESC Memórias.

${ }^{59}$ Nelli identifica em suas fotos a colônia como Sesc Bertioga. Nas publicações $O$ Sesc em Marcha, Revista do Sesc e nos relatórios anuais de 1947/48 é comum usar o nome Colônia Ruy Fonseca.

${ }^{60}$ De acordo com SEABRA "é a habitação cujo uso é eventual, a qual, portanto, não se constitui em suporte da vida cotidiana" (1979:1).
} 
Essa valorização mobilizará um número cada dez maior de veranistas da capital e do interior do Estado, agentes públicos e privados, como as construtoras e incorporadoras, mas também turistas acompanhados de máquinas fotográficas.

A presença da fotografia nesse ambiente tampouco é uma novidade. Em 1904, no Rio de Janeiro, o Jornal do Brasil, em sua edição de domingo, já revelava a relação íntima entre as câmeras fotográficas Kodak e os banhos de mar.

\begin{abstract}
A fotografia e as praias - exclamava há dias uma venerável senhora que ainda vai às praias para tomar banho. É uma praga, ninguém toma banho e todos tiram fotografias! Se uma pessoa se levanta - clic! - ouve-se um estalido; se se assenta, tem de tomar posição conveniente, porque fica rodeada de objetivas ávidas (MAUAD, 2000:145).
\end{abstract}

Isso mostra que, ao lado da cultura de praia ainda recente, começava a desenvolver-se um olhar turístico, acompanhado de câmara fotográfica, o que é indicativo das novas formas de percepção visual surgidas no século XIX (URRY, 1990: 182-187).

Cleonice frequentava estes espaços novos em rápido processo de transformação. Ela também modifica a paisagem em suas fotos, qualificando-a e definindo-a com sua presença e com os registros visuais. Ao reunir, em uma coleção, séries de imagens dessas viagens à praia, torna-se ainda uma narradora dos processos de transformação em curso. Tais transformações não são, porém, o objetivo de suas fotos; as mudanças na paisagem figuram nas imagens como o punctum de Roland Barthes (1984), saem involuntariamente, o que estimula o analista recuperar, por meio desses detalhes não propositais, o contexto de produção social das imagens, que dão a ver, como é o caso da foto 48, as marcas do processo de melhoramentos urbanos do caminho para o mar, como os postes de energia elétrica, mas também (e por que não) a precariedade do caminho.

Suas imagens fazem referência à atual Região Metropolitana da Baixada Santista $(\text { RMBS })^{61}$ destacando-se as seguintes cidades: Santos, Itanhaém, Bertioga, Ubatuba, Praia Grande. Cabe observar que, nesses quarenta anos de acúmulo de imagens, cidades como Praia Grande e Bertioga ainda não existiam jurídica nem administrativamente.

\footnotetext{
${ }^{61}$ A região criada em 1996 compreende os seguintes municípios: Bertioga, Cubatão, Guarujá, Itanhaém, Mongaguá, Peruíbe, Praia Grande, Santos, São Vicente. É importante notar que, antes dessa diferenciação, Santos abrange uma grande quantidade de distritos. Esse fato torna difícil a distinção entre um lugar e outro uma vez que todos eles estão em alguma medida ligados à cidade mais rica do litoral paulista, pois afinal o principal porto do País ficava em Santos.
} 
Santos, no entanto, já a partir da segunda metade do século XIX passa a ter destaque como porto de contato e comunicação entre o planalto e o mundo.

A memória material fotográfica de Cleonice permite visualizar a dinâmica da comunicação entre o planalto e o litoral, que fomentou um novo estilo de vida marcado pela cultura balneária e pela consequente "valorização do corpo". (CORREA, 2008: 165-184).

\subsection{Tipologias litorâneas}

Temas recorrentes nas fotografias da coleção $\mathrm{CMH}$ me inspiraram a criação de algumas tipologias analíticas fundamentadas também no edital do concurso de fotografia amadora realizado em 1955 em Santos, por ocasião do Congresso Nacional de Turismo ${ }^{62}$. O concurso estabelecia tais categorias para estimular os amadores a registrarem aspectos da cidade santista. Retive apenas aquelas que podiam ajudar a olhar o material de Cleonice: movimento nas praias, ruínas e monumentos históricos. Acrescentei ainda os temas hospitalidade e tipos locais, categorias que são analisados por meio das fotos ao longo do capítulo.

A análise tem inicio com um cartão postal que mostra o caminho que levava às praias, em seguida acompanha o movimento nas praias, passando pelo lazer na inédita Rodovia Anchieta. As fotos que vem na sequência exibem um conjunto de estabelecimentos hoteleiros, nos quais se pode recuperar informações sobre o que eram os serviços de pensões, em um mercado ainda muito novo. Ficar nestes lugares implicava passeios pelos arredores para ver recantos pitorescos, monumentos históricos, ruínas e mesmo estabelecer algum contato com os tipos locais. Ligado a hospedagem a compra da segunda residência revela situações novas, se comparada à forma como o grupo se hospedava antes, como a tomada de fotos a partir da residência secundária, cujo horizonte é a movimentação de banhistas na orla, ou o registro do interior do apartamento no dia da inauguração. O capítulo termina com uma foto síntese da sociabilidade familiar, mas também da enorme transformação deste espaço promovida pelos agentes imobiliários. e .

\footnotetext{
${ }^{62}$ Segundo informações de Denise Puertas de Araújo (2008:118).
} 


\subsection{O caminho do mar: comunicação, circulação e memória fotográfica}

Para compreender a história dos usos da zona costeira de São Paulo pela população que saía da capital e mesmo do interior do estado, em busca de paisagens naturais, de sol e mar, é necessário entender, por um lado, como a estrada que ligava São Paulo a Santos (foto 48) foi recebendo melhorias ao longo do tempo, dinamizando a circulação de pessoas, mercadorias e representações visuais e, por outro, como o hábito dos banhos de mar se constituiu historicamente não só entre os paulistas, mas entre os brasileiros em geral.

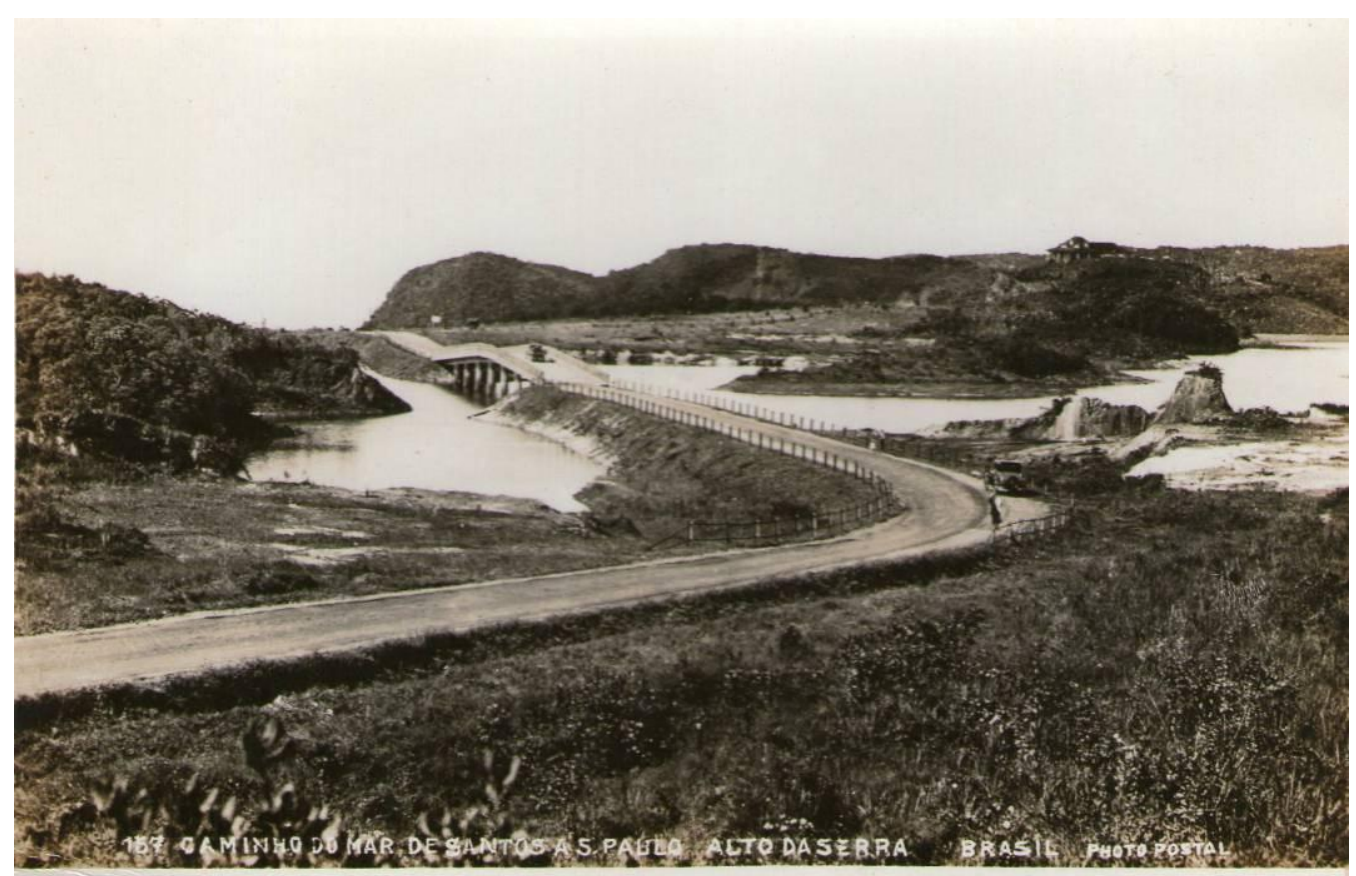

Foto 48: "Caminho do mar de Santos a São Paulo, Alto da Serra, Brasil Photo Postal 1942". Dimensões: Cartão postal fotográfico enviado por Tia Lina encontrado na coleção de fotografias G. H. Este cartão permite visualizar um trecho da ligação entre a metrópole e o litoral antes da inauguração da Via Anchieta em 1947. O conteúdo da fotografia mostra um caminho que só se modificou com a construção desta estrada.

Ao contrário do Rio de Janeiro, São Paulo se encontra distante do mar, embora a ligação entre o planalto e a Baixada Santista remonte ao início da colonização; de modo que transpor a barreira natural da Serra do Mar sempre envolveu grandes esforços. Segundo Mario Antonio Ferreira Barreiros, a construção do caminho para o mar começa em 1560, quando Mem de Sá encarrega os jesuítas de abrir uma nova trilha pela Serra do Mar. A abertura desse caminho substituía as estreitas picadas indígenas, inadequadas 
às tropas de burros e mulas que transportavam víveres e demais mercadorias (2002:7). Em fins do século XVIII, o porto de Santos recebeu melhorias cujo objetivo era escoar o açúcar produzido na capitania de São Paulo. No decorrer da segunda metade do século XIX, a relação entre o litoral e o planalto foi redimensionada. Na passagem para o século XX Santos deixa de ser apenas uma vila entre outras e torna-se o principal porto do país. Em 1892, 1893 e 1909, as transformações do porto relacionavam-se à situação geral do território paulista. De acordo com Ana Lanna:

[...] não se pode desvincular a tão reivindicada reforma do porto da situação geral do estado de São Paulo. Tanto nas reformas do porto quanto nas intervenções sanitárias mais do que a situação mesma da cidade de Santos estava em jogo sua posição estratégica na relação com o planalto, seja para escoar a produção cafeeira, que significava a maior riqueza nacional, seja importar trabalhadores. Tratava-se da condição santista de porta de entrada do mar e do sertão (LANNA, 1996: 61).

As duas cidades constituem faces de um mesmo desenvolvimento devido ao enriquecimento do planalto com a monocultura cafeeira. A ligação a partir de então é feita por linha férrea. Entre São Paulo e Santos, “cidades irmãs” no dizer de Aroldo de Azevedo (1958:30) essa importância remontava à origem de ambas. Melhorar o caminho de ligação e comunicação entre elas era, portanto, fundamental para projetá-las no contexto nacional e internacional. Com efeito, no início do século $\mathrm{XX}$, o então presidente do Automóvel Clube de São Paulo, Washington Luís, recomendava a macadamização ${ }^{63}$ da via que levava ao mar ou, alternativamente, a construção de uma nova estrada para funcionar como auxiliar e complementar a estrada de ferro, de modo a permitir o futuro tráfego de automóveis (LUNA \& COSTA, 1979:7).

Mais tarde, em 1920, Arthur Rudge da Silva Ramos retoma o processo de recuperação da estrada histórica aberta pelos jesuítas, mas abandonada desde a inauguração da estrada de ferro em 1867. Cria-se então a "Sociedade Caminho do Mar", implanta-se um pedágio e passa-se a reconstruí-la. Em 1928, sob o governo do Estado, a estrada recebe nova pavimentação asfáltica e naquele momento já se discutia a construção de uma nova estrada com maior capacidade e desenho mais adequado ao automóvel (BARREIROS 2002:7), como sugerira anos antes Washington Luís. Essa construção demorará anos para acontecer de fato e mesmo a via ferroviária só viria a se concretizar na extensão e planejamento esperados pelo governo do Estado, em 1938,

\footnotetext{
${ }^{63}$ Sistema de pavimentação com pedra britada (quebrada em tamanhos bem pequenos) e saibro (areia misturada com argila). Disponível em: http://www.dicio.com.br/saibro/ Acesso em 15/8/2012.
} 
após a implantação do projeto modernizador. Esse projeto vinha sendo inviabilizado pela companhia inglesa S. Paulo Railway Company, detentora até 1946 do privilégio de exploração da ligação entre a capital e Santos ${ }^{64}$.

É nesse contexto de transformações que Cleonice começa a frequentar a Baixada Santista em 1929, um ano depois do início da pavimentação asfáltica. Nessa época ia-se para essas praias, sobretudo, fazendo uso da ferrovia. $\mathrm{O}$ acesso pelas estradas era ainda bastante precário, o que se manteria até 1947 , como pode ser constatado na foto 48 , que mostra o caminho do mar em tomada panorâmica antes da construção da Via Anchieta. Nas imagens guardadas por Cleonice, relativas aos anos 1920 e meados da década de 1930, não há informações de como ela fez esse percurso. Tudo leva a crer que tenha se valido do trem, posto que os carros naquele momento estavam restritos aos segmentos da elite paulista ${ }^{65}$. Pode-se supor que o grupo (foto 49) tenha viajado pela via férrea Santos-Jundiaí, uma vez que a Estrada de Ferro Sorocabana (ramal Mairinque-Santos) só foi inaugurada em 1938 como parte do programa de expansão da ligação entre o planalto e o litoral (BERNARDINI 2011: 41-69).

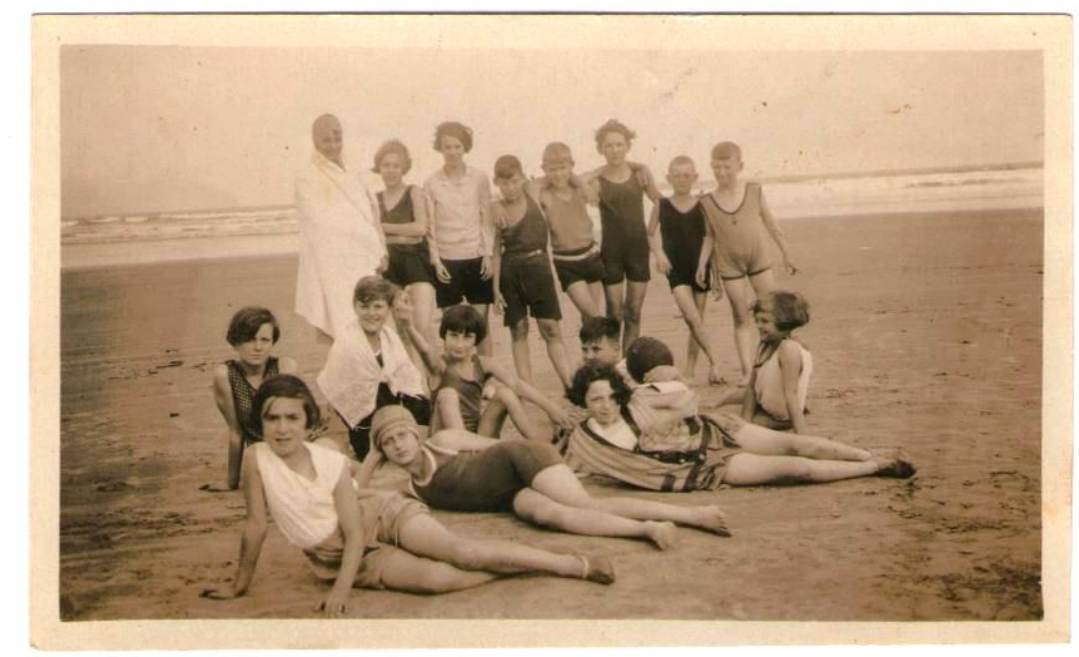

Foto 49: Cleonice em Praia em Santos, 1929. Dimensões: 6, 5 x $11 \mathrm{~cm}$. Papel Velox.

A prática dos banhos de mar, que, em países europeus como Inglaterra e França surgiram timidamente ao final do século XV, difunde-se no Brasil inicialmente no Rio de Janeiro, então capital federal, no início do século XX, e se "espalha pelos principais centros urbanos costeiros brasileiros e, a partir da segunda metade do século, por toda

\footnotetext{
${ }^{64}$ Ver a respeito da relação entre poder público e poder privado na expansão da rede ferroviária de São Paulo no início do século XX, BERNARDINI (2011: 41-69).

${ }^{65}$ A esse respeito ver: LEFÈVRE, (1985:50-64); INOUE (2011: 175-176).
} 
costa do país" (MACEDO e PELLEGRINO 1996: 156). No caso de São Paulo, a ocupação do litoral ocorre quando as praias passam a se constituir em grandes áreas de lazer (VIEIRA 2008:). Ainda que o banho de mar não fosse exatamente o que atraía os turistas que para lá acorriam, o uso da praia como espaço de recreação era uma novidade como ressalta Maria da Glória Lanci da Silva.

Até o final do século XIX as praias ainda eram uma novidade como espaço de lazer e poucas pessoas se aventuravam a tomar banhos de mar, preferindo nadar em rios e lagoas ou frequentar os balneários serranos. Parte da elite social e econômica, porém, influenciada pelas novidades da Europa, passou a construir empreendimentos turísticos - hotéis, chalés, casas - à beira-mar, criando os primeiros balneários litorâneos (SILVA, 2003, 59) ${ }^{66}$.

O desenvolvimento do gosto pelo balneário e pelo banho de mar, bem como o contato com a areia e a exposição ao sol, se tornaram fatores associados, desde fins dos século XIX, à vida saudável. Desse momento em diante, os profissionais da saúde começam a prescrever essas e outras águas como fontes terapêuticas, por suas virtudes curativas $^{67}$. A ligação entre o planalto e o mar estava, então, não atrelava-se apenas à internacionalização e ao escoamento da produção de café, mas também a mudanças culturais importantes como a inédita valorização das águas salgadas e ainda ao contato com a natureza, consumo e contemplação da paisagem.

$\mathrm{Na}$ foto 49, Cleonice (a menina de camisa branca) aparece em primeiro plano com parte do grupo que esteve com ela no sítio na Freguesia do Ó em 1929 (foto 16). O retrato grupal sugere que as praias locais fossem completamente vazias, o que não é verdade. Uma crítica externa das condições de produção da imagem mostra que a fotografia, ao recortar a realidade, cria uma realidade nova, congelando um fragmento do tempo e fixando uma certa representação do espaço, neste caso, como lugar vazio; trata-se, pois, de um "arranjo cultural" do espaço geográfico em um determinado instante (LEITE, 1993:19). O movimento de outros banhistas na praia é deixado de fora do enquadramento, o que torna a presença do grupo um tanto exclusiva ${ }^{68}$. Ao contrário do que mostra a foto, o litoral paulista nessa época contava, com uma grande

\footnotetext{
${ }^{66}$ Posição semelhante é adotada por Alain Corbain quando mostra que a praia, antes de tornar-se um espaço de prazeres, era algo repulsivo. Ver: CORBAIN, (1989). Para os primórdios do uso das praias no Rio Grande do Sul ver: CORREA, (2010).

67 A partir da década de 1930 na Alemanha surge uma nova percepção do corpo humano, a cor do mármore é substituída pela cor bronzeada das terapias associadas ao sol, ar e água. CORREA, 2010:177.

${ }^{68}$ Ver por exemplo as fotografias das páginas 10, em meados de 1920, e 168, em 1915, cujo ângulo muito próximo abstrai a dinâmica da vida no entorno dos banhistas no livro de Gerodetti \& Cornejo 2001.
} 
diversidade de visitantes de diferentes classes sociais, que se alojavam nas novas construções litorâneas.

Odete Seabra indica que, em decorrência do processo de enriquecimento de Santos no começo dos anos 1920, a exploração balneária da cidade fazia com que suas ruas estivessem "sempre cheias de gente, as praias concorridíssimas, os clubes de regatas com suas sedes sempre repletas, em toda parte enfim, a cidade entoava de vida" (1979: 14-15). Durante a década de 1930, por sua vez, a praia tornava-se um destino cada vez menos exclusivo às elites e atraía uma "população urbana constituída por artesãos, profissionais liberais e por um proletariado industrial" (idem:16). A praia vazia da imagem contrasta assim com a intensificação da vida urbana no litoral, porém ambas constituem partes de um mesmo fenômeno: o aumento da comunicação e da circulação entre o planalto e a praia.

A disposição corporal de Cleonice na imagem parece sugerir ${ }^{69}$ alguma proximidade afetiva com o fotógrafo, que talvez fosse seu pai, ou um tio, ou quem sabe até mesmo sua mãe, Dona Ida. Vale, aqui, refletir sobre a relação mulher-fotografia. Apesar da possibilidade de Dona Ida ser a autora da foto, a presença de uma mulher atrás da câmara, nesta situação específica, é improvável, embora não impossível. À mulher estavam reservados os papéis de modelo e de organizadora da memória fotográfica em álbuns lógicos, soltos ou em caixas de sapato, e raramente o de produtoras do registro (LEITE, 1993; SILVA, 2008). Há que matizar, todavia, tal afirmação, pois a difusão de máquinas de fácil manipulação permitiu em determinadas situações que "mães, tias e primas" fizessem uso do equipamento para a documentação da vida infantil no ambiente doméstico: "banhos de criança, hora do almoço na cadeirinha de bebê, o dever de casa, as brincadeiras infantis, fragmentos do cotidiano e crescimento das crianças" (MAUAD, 2000:146).

Outra possibilidade de solucionar o problema da autoria da imagem é ver nela um produto da dinamização da vida balneária, cujos "fotógrafos de jardim ou lambelambe" tomavam o registro, prática que também se difundiu no litoral tanto quanto em São Paulo (idem, p.14).

\footnotetext{
${ }^{69} \mathrm{O}$ primeiro plano, como se verá mais tarde, não só agrada a Cleonice, mas também ao Sr. Souza. Esse plano como já mostrei no capítulo anterior não serve apenas para garantir a posição de pessoas importantes, ele pode ser usado para valorizar figuras que estão a distância como na foto 45 .
} 


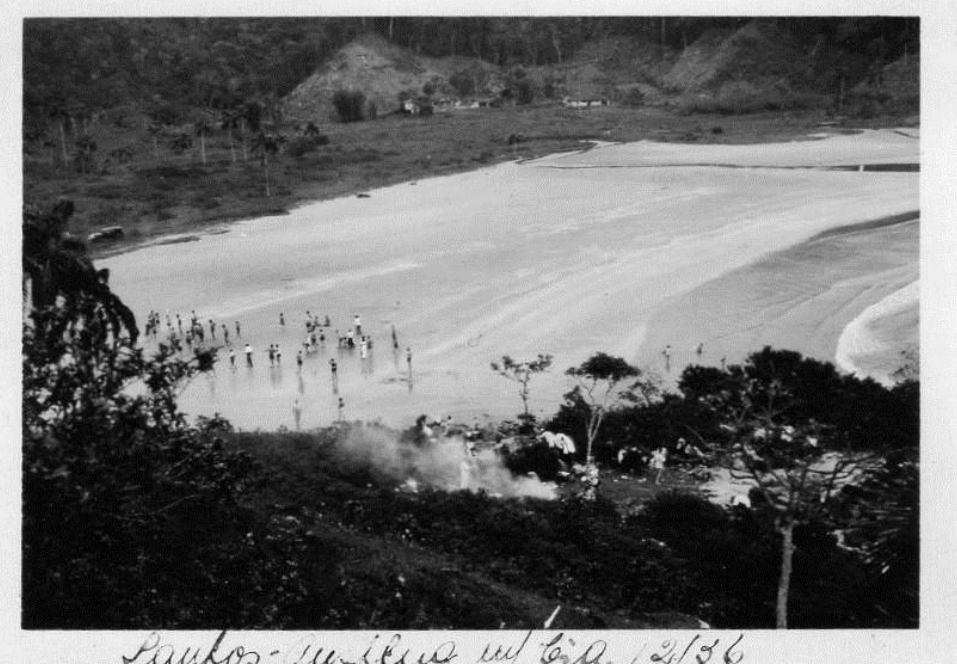

Foto 50: Vista Panorâmica de Santos, 1936. Ampliação das dimensões originais: 8,5 x 6 cm.

As fotos dessas viagens iniciais para a praia têm como característica o anonimato do fotógrafo e a identificação genérica do local. Em dezembro de 1936, a genérica praia de Santos, tal como identificada na legenda da foto é vista à distância, e embora não se possa localizar o lugar, podem-se ver as práticas de espaço, sobretudo ampliando-a (detalhe 50a), cuja fumaça é um indício de churrasco, forma possível de sociabilidade em tal ambiente.

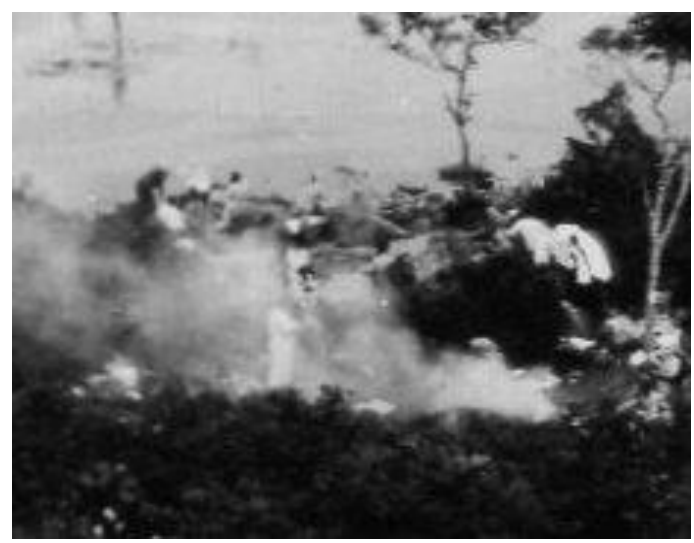

Detalhe 50 a: 
Enquanto há pessoas reunidas em torno da fumaça a uma razoável distância da água, nota-se ao longe que outras andam na areia, à beira mar. Tal distância do fotógrafo em relação à cena dissolve as hierarquias espaciais, anula as diferenciações entre pessoas, roupas, posturas e expressões faciais, como assinala Miriam Moreira Leite. Se, por um lado, ocorrem perdas, por outro obtém-se uma visão panorâmica que organiza a paisagem e as ações humanas (1993:19). Daí ser possível dividir a imagem em dois diferentes planos em que se desenrolam relações sociais: o churrasco (detalhe 50 a) e os divertimentos nas areias à beira-mar (detalhe $50 \mathrm{~b}$ ).

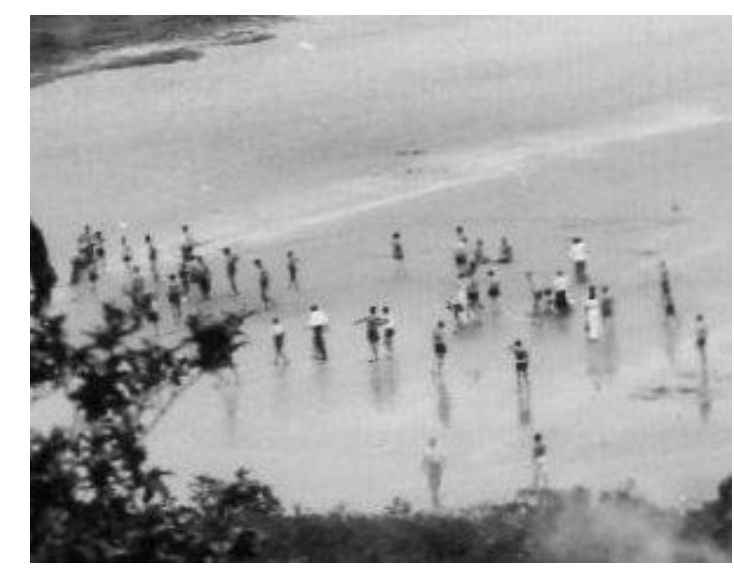

Detalhe 50 b.

Neste tipo de imagem é possível notar resquícios da importância da visão panorâmica na cultura visual do século XIX, que ofereceu elementos de composição e temas à fotografia amadora do século XX, ainda que com reduções ou ampliações de usos e sentidos. Para Heloisa Barbuy "o sentido da visão panorâmica” está ligado "ao poder didático que se atribui à visão - aquela ideia de ver para compreender" (2002: 74). Pode-se ressaltar, entretanto, que não se trata do panorama completo, em que se pode visualizar uma paisagem de uma ponta a outra, mas de um panorama adequado às limitações da tecnologia da câmara do fotógrafo amador. O olhar do fotógrafo anônimo está assim marcado por códigos ligados à cultura visual corrente, ainda fortemente associada a uma gramática do visível oitocentista. Mostrei no primeiro capítulo como esses padrões visuais do século XIX permanecem no século XX ao mencionar os retratos de estúdio dos primos de Cleonice em Brusque.

No mesmo ano de 1936, com 15 anos, ela aparece em uma foto de formato vertical no que se pode chamar de ponta da praia (foto 51). Aqui, a proximidade da tomada permite que apenas ela seja identificada, ao passo que suas amigas permanecem no anonimato. Cleonice veste o mesmo maiô que usará mais tarde no Clube de Regatas 
Tietê (fotos 25 e 26) evidenciando, entre outras coisas, que um mesmo traje permitia circulação em diferentes ambientes. Doze anos mais tarde Cleonice aproveita o acesso facilitado pela abertura da rodovia Anchieta para ir à praia.

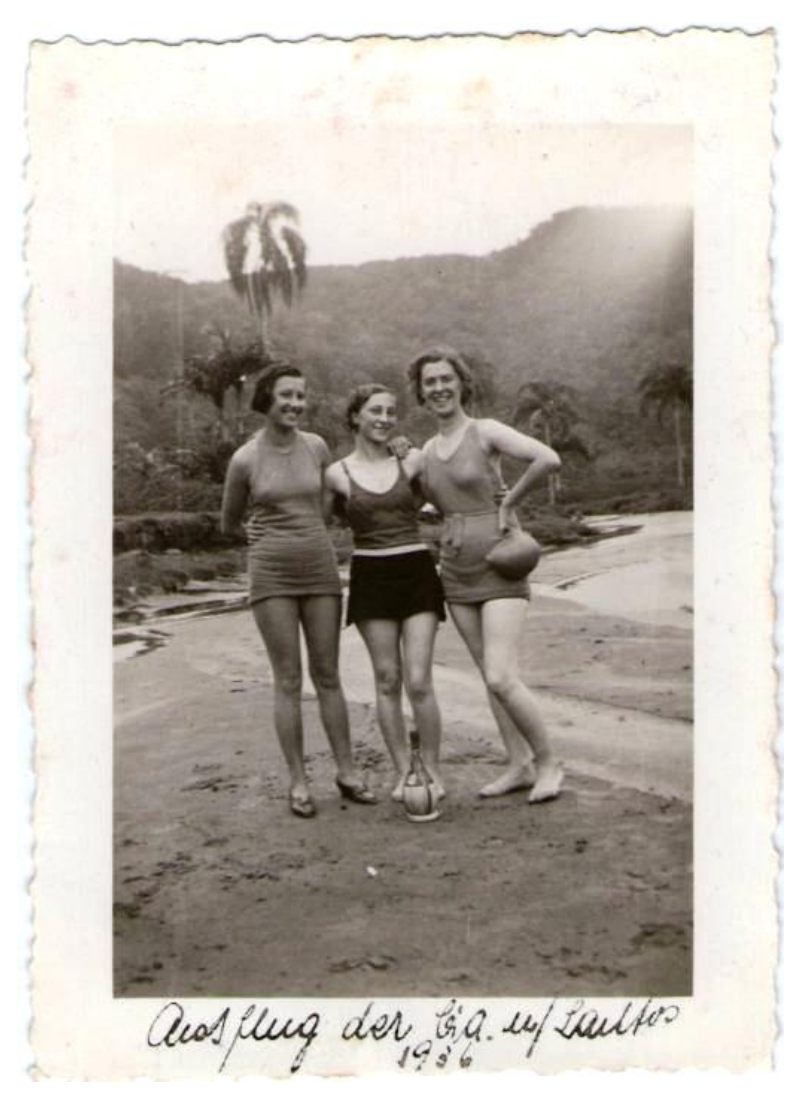

Foto 51: Cleonice à direita com amigas em Santos, 1936. Ampliação das dimensões originais $9,5 \times$ 7,0 cm.

\subsection{Um novo caminho: Piquenique na Via Anchieta}

Em 1939, tem início a construção da Via Anchieta, porém, com o advento da II Guerra Mundial, os trabalhos são interrompidos e a entrega da pista ascendente só ocorrerá em 1947 (BARREIROS, 2002:8); em 1953 será entregue a segunda pista da serra. Ao todo são cinquenta e cinco quilômetros, em pista dupla, dos quais trinta no planalto, treze na serra e doze no trecho da baixada. A estrada conta, no segmento de serra, com cinco túneis, onze viadutos na via ascendente, treze na descendente e três quilômetros de pontes e lajes (LUNA \& COSTA, 1979:8). Essa obra proporcional à grandiosidade de São Paulo auxiliou a cidade entre, 1939-1945, a se tornar o maior centro industrial da América Latina. Com a construção da Via Anchieta, São Paulo 
superava definitivamente a barreira natural da Serra do Mar dando assim mais um passo em seu caminho para o progresso tão exaltado pela sociedade urbano-industrial (FERRARA 1999:46).

Cleonice, os Souza e um grupo de amigos usufruiriam de um empreendimento que mudaria definitivamente a relação entre o planalto e o litoral. O curioso é notar que se trata de fato do usufruto da via, pois, na altura de Rio Grande da Serra, o grupo divertiu-se sob um dos viadutos da estrada. Desse passeio resultou uma série de 9 fotos, das quais mostro apenas 4 . A foto 52 exibe um fragmento da enorme parede de concreto que serve de fundo ao retrato coletivo perto da qual foi montado um cenário de refeição com toalhas, garrafas e banquinhos de armar. Esta parece ser uma das fotografias feitas pela máquina, antecipadamente programada por seu dono, Sr. Souza, que aparece entre o homem à esquerda e a criança de chapéu branco.

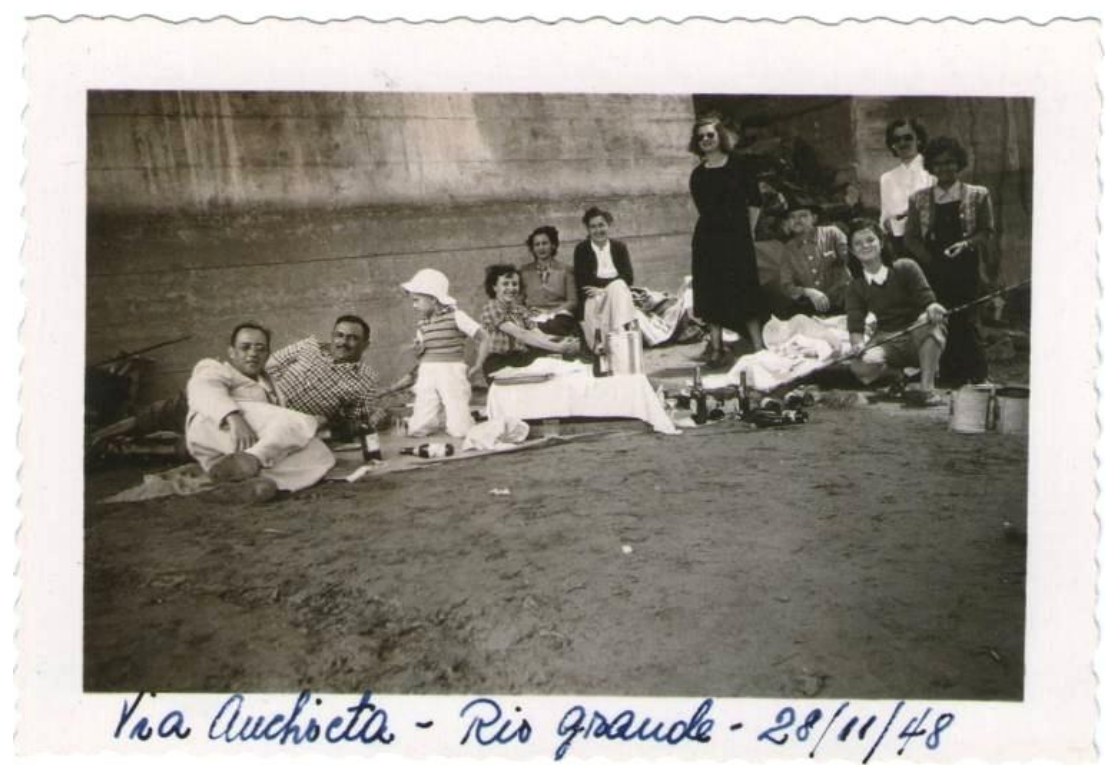

Foto 52: Cleonice, a família Souza e anônimos divertindo-se sob a Via Anchieta, 1948. Ampliação das dimensões originais: 6,5 x 9,5 cm.

A sequência transcorre como um filme. Assim, foram registrados vários instantes: na foto 53, as mulheres exibem, individualmente, um peixinho nas mãos. Dircinha de calça coloca-se entre Cleonice e sua mãe, posição muitas vezes ocupada pela menina nos registros fotográficos. Ambas, a mãe e a amiga da família, usam óculos escuros. As varas empunhadas prolongam a verticalidade da posição das mulheres e o dia parece nublado, indício evidenciado pelas roupas usadas. 


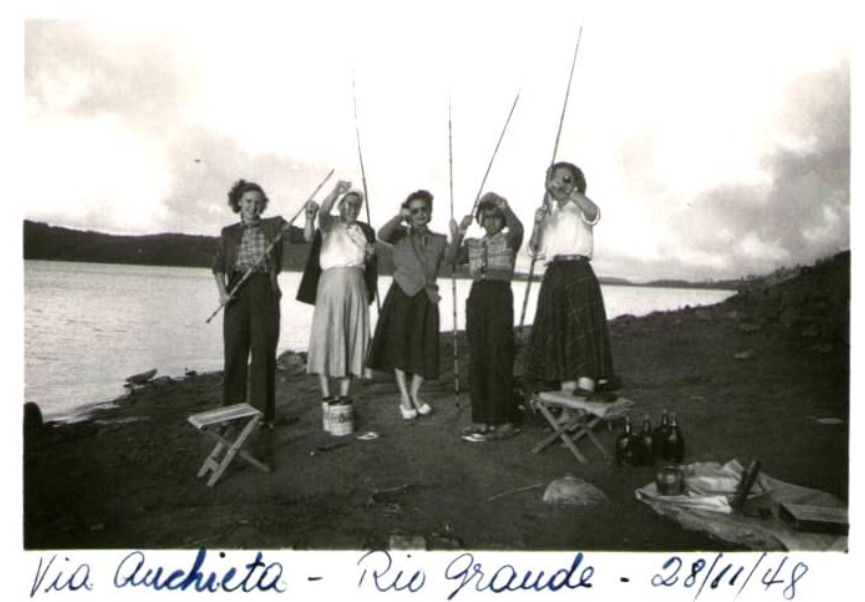

Foto 53: Cleonice, Olga e Dircinha exibem-se para a câmara com as varas de pescar. Dimensões: $6 \times 9 \mathrm{~cm}$.

$\mathrm{Na}$ foto 54 Cleonice, expressando alegria, segura um arco com os peixes que o grupo pescou. Ela ocupa o centro da imagem e sorri diante dos resultados da pescaria, enquanto Dona Olga e Dircinha à esquerda a observam no gesto feliz. Nada, senão a legenda indica que eles estão sob a Via Anchieta revelando o papel da fotografia como um elemento modificador, capaz de não apenas captar o espaço, mas produzi-lo.

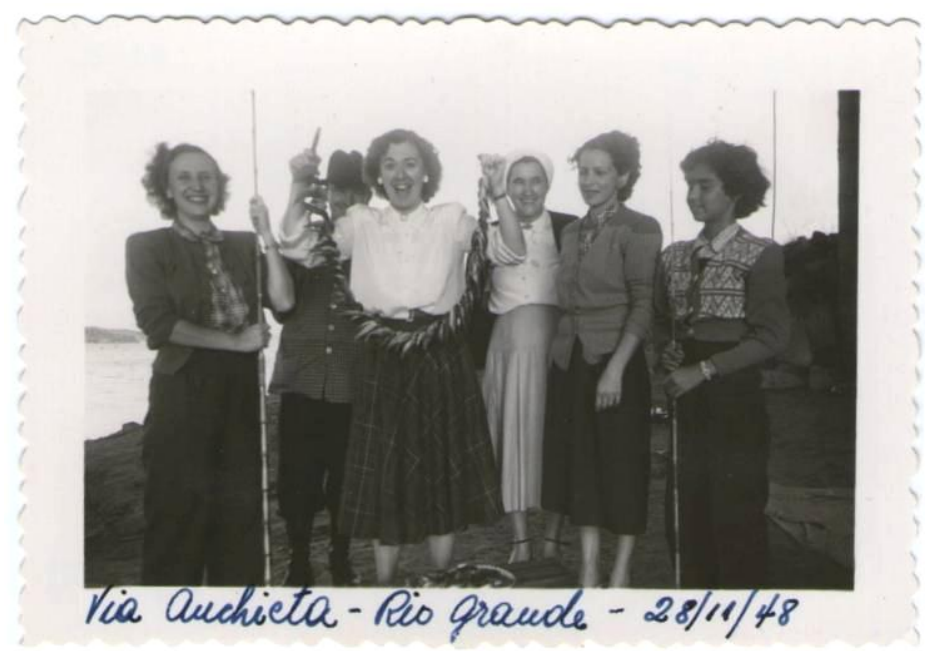

Foto 54: Cleonice exibe um arco de peixes sob a Via Anchieta em 1948. Dimensões: 6 x 9 cm.

Finalmente, o grupo parece preparado para ir embora e, ao contrário da foto 52 tirada embaixo de um viaduto da Via Anchieta, ele agora voltou para o nível da estrada (foto 55). Dircinha, Dona Olga e Cleonice de óculos escuros, além de uma mulher 
anônima, estão acomodadas no banco traseiro. Elas esperam o fotógrafo amador, o Sr. Souza Filho, que considera também este um momento oportuno para mais um registro. Afinal, essa cena jamais se repetirá, mas uma vez captada, fará com que a experiência do momento se torne sempre presente no futuro. Conforme demonstrado no capítulo 1, a concepção corrente de fotografia, ao menos para a Foto Velloso ${ }^{70}$ era que: "a fotografia é o passado no presente e a reminiscência no futuro". Tal concepção transparece inclusive no modo como Cleonice colecionou fotos de si mesma.

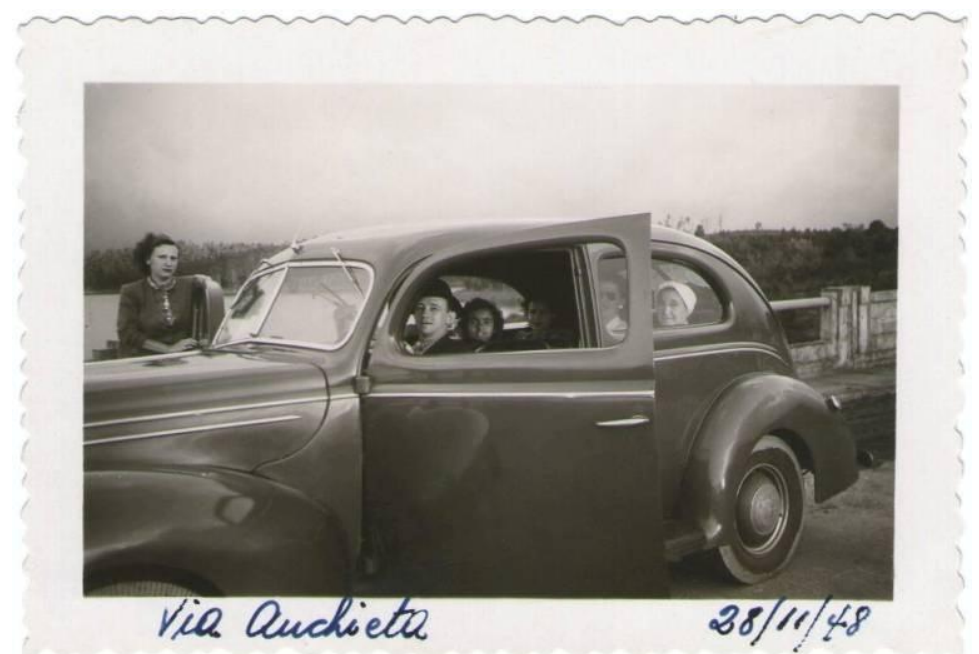

Foto 55: Automóvel na Via Anchieta que levou o grupo para o passeio em 1948.

$\mathrm{Na}$ última imagem do passeio (foto 55), destacam-se os dois grandes símbolos da modernidade urbano-industrial: o carro e a ponte, obra de engenharia ao lado da qual o grupo saboreou um piquenique. O primeiro, significativo nos termos de Zita Rosane Possamai representa "não apenas a tecnologia, capaz de transportar o homem através do espaço, mas também a velocidade, baluarte dos novos tempos" (2007:66). O carro no contexto paulistano expandiu-se rapidamente como meio de transporte, e foi fator de transformação relevante da nova forma assumida pela cidade e por seus limites territoriais. Nesse ano de 1948, o número de automóveis registrados no Brasil era de $169.317^{71}$, e um deles pertencia ao motorista não identificado da foto 55. Como assinala Marc Boyer "o carro tornar-se-á" - no Brasil apenas em fins dos anos 1960 e meados de 70 - "o rei do turismo de massa" (BOYER, 2003:10).

\footnotetext{
${ }^{70}$ Comércio de materiais fotográficos. Essa empresa parece surgir em meados dos anos 1950. Nada sei sobre ela e não aprofundo a discussão a seu respeito.

71 Segundo dados do IBGE para o ano de 1948 http://www.ibge.gov.br/seculoxx/economia/atividade_economica/setoriais/transportes/transportes.shtm acesso em 14/7/2011.
} 
O segundo símbolo é a obra de engenharia, cuja melhor descrição proveio do sociólogo Roger Bastide. Ele dirá: "Uma magnífica rodovia liga São Paulo a Santos, através da floresta tropical, passando por uma série de pontes, de túneis, de curvas harmoniosas, que a transformam numa obra-prima de engenharia" (1979:143). O elogio de Bastide não é gratuito; de fato, esse empreendimento foi realizado com tudo o que havia de mais moderno em termos de engenharia estimulando a escolha pelo fluxo rodoviário $^{72}$.

\subsection{A hospitalidade balneária}

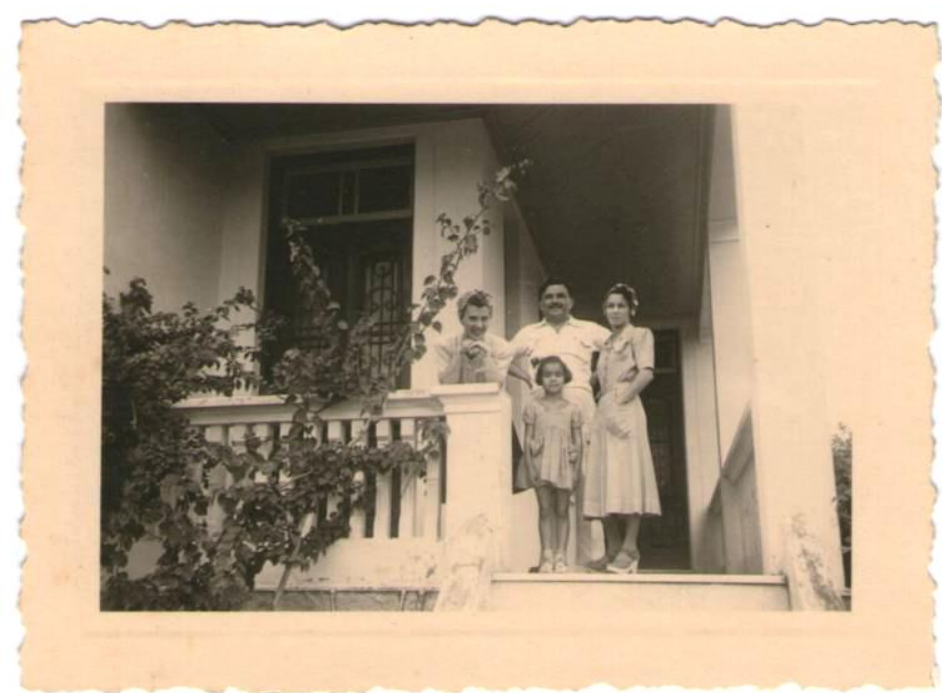

Foto 56: Cleonice e a família Souza em 1942 na pensão Stella Maris na Praia José Menino. Ampliação das dimensões originais: 6 x 9 cm. Revelação: Papelaria Léo, papel Agfa Lupex.

Cleonice e os membros da família Souza não precisaram esperar a construção da Via Anchieta para efetuarem seus primeiros passeios ao litoral a partir de 1941. Juntos, eles permanecerão nos destinos santistas inicialmente não mais do que um dia ou dois relativos ao fim de semana, mas logo necessitarão de hospedagem para períodos mais longos. Foi exatamente este o caso do passeio à Praia José Menino (foto 56). O grupo

\footnotetext{
${ }^{72}$ Pode-se notar em texto escrito por Prestes Maia em 1950 a importância do transporte rodoviário, especialmente o carro de passeio como fator urbanístico, por exemplo, para o planejamento de Santos. Segundo palavras do autor: "No movimento de passageiros a rodovia apresenta além de aprazimento paisagístico, a vantagem de levar também o carro que o turista usará nas praias. Aos domingos o movimento já ascende a quase 10 mil veículos. O espaçamento dos ônibus desceu a 15 minutos e, em contraposição os vagões da São Paulo Railway passaram a correr vazios". Citado em SEABRA, (1979: 44).
} 
aproveitou o feriado de finados e hospedou-se por dois dias na pensão Stella Maris ${ }^{73} \mathrm{em}$ $1^{\circ}$ e 2 de novembro de 1942. Esse importante bairro e praia de Santos era um dos locais preferidos pelos turistas de um dia ou dois.

Na década de 1940, acompanhando uma tendência na produção dos alojamentos praieiros, verifica-se uma ampliação do número de pensões que atendiam a um público de posses modestas que não costumava frequentar hotéis e não possuía residências secundárias na orla marítima.

A pensão Stella Maris (foto 56), encimava à entrada exibida na foto 57. Foi provavelmente dali que o Sr. Souza registrou o portão que levava à rua. O alojamento se encontrava a poucos metros da praia, que devia estar próxima da rua que aparece ao fundo na foto 57. Nela, podem-se ver postes de luz elétrica e o ajardinamento da orla como um continuum entre o quintal da pensão e a rua ${ }^{74}$.

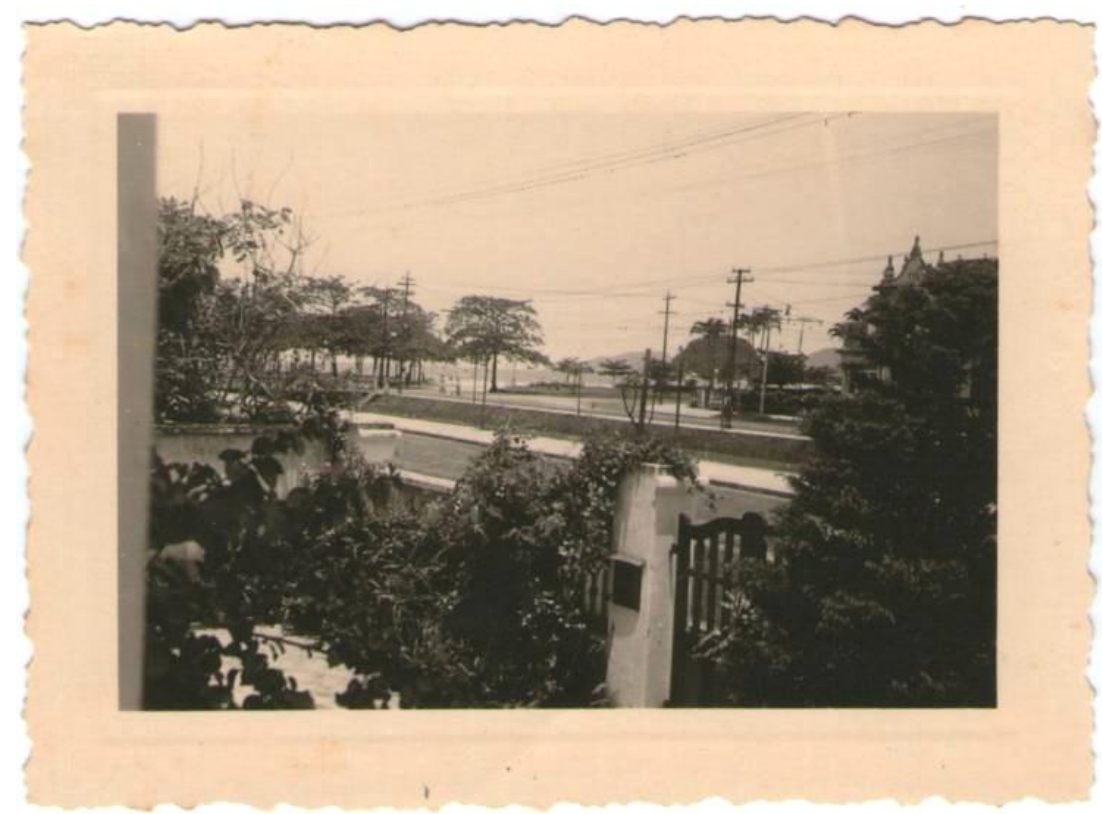

Foto 57: Vista do quintal com frente para rua da pensão Stella Maris em 1942. Ampliação das dimensões originais: 6 x 9 cm. Revelação: Papelaria Léo, papel Agfa Lupex.

\footnotetext{
73 Não encontrei nenhuma referência a essa pensão em Santos. Contudo, é possível entender a importância que esse tipo de alojamento teve na recepção da população urbana que vinha de São Paulo. Com o processo de verticalização da orla das praias para fins residenciais (segunda residência), essas pensões serão gradativamente popularizadas; nos anos 1950 atingem seu apogeu, declinando nos anos 1970. Ver (SEABRA 1979 pp. 33-38).

${ }^{74}$ Girodetti e Cornejo afirmam que esse paisagismo da orla marítima santista remonta à urbanização ocorrida em 1935 e ao ajardinamento em 1936. Idem p.93.
} 
O grupo foi à praia (foto 58), e Dona Olga envolvida em seu roupão de banho felpudo ajudou Cleonice a proteger-se do sol passando-lhe, possivelmente, uma loção de proteção contra a agressão dos raios solares sobre a pele desprotegida ${ }^{75}$; ambas as mulheres iniciam uma aproximação gradativa que culminará em 1960, por ocasião do batismo de Cleonice, tendo o casal Souza como padrinhos - foto 10.

Os trajes de banho sofreram grande evolução entre o início do século XX e meados dos anos 1940. Em 1915 eram comuns toucas e roupão de toalha felpuda; às crianças eram permitidos trajes mais sumários (GIRODETTI \& CORNEJO, 2001:171), como a usada por Cleonice e Dircinha. Vê-se, pela foto, que ainda nos anos 40, o roupão funcionava como vestimenta em dois momentos distintos: na ida até a areia e depois do banho de mar.

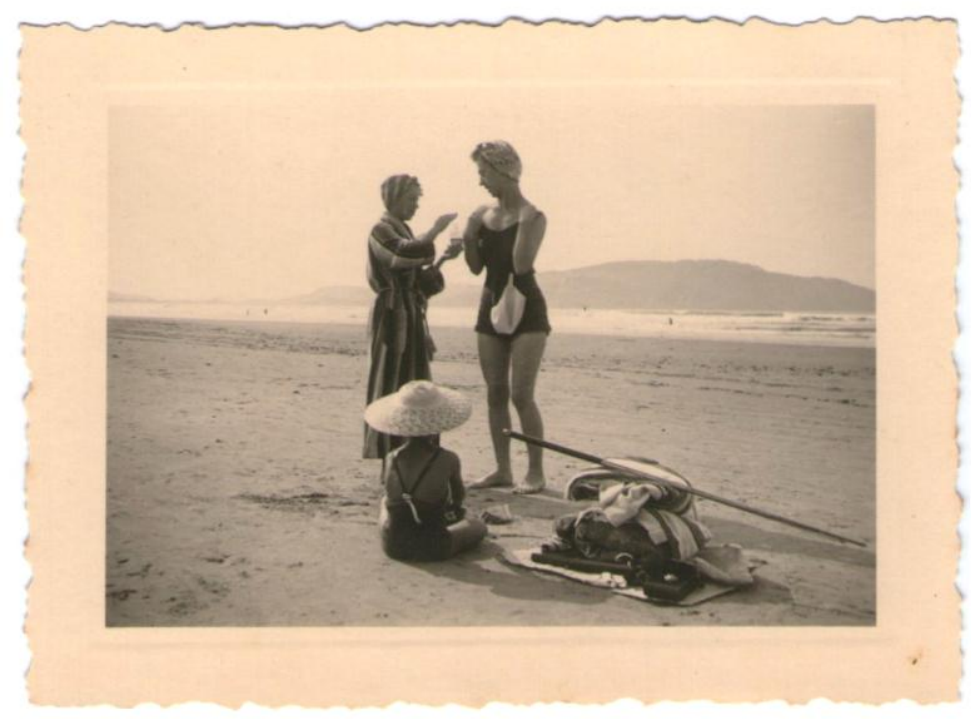

Foto 58: Cleonice recebendo protetor solar e Dircinha de costas. Praia José Menino, 1942. Ampliação das dimensões originais: 6 x 9 cm. Revelação: Papelaria Léo, papel Agfa Lupex.

A facilidade para fazer fotografias era tamanha nesta época que é bem possível que em imagens, como a foto 59, o registro tenha sido feito por alguém que andava, como o grupo, nas areias da praia. Nesse sentido, a máxima da Kodak estava bastante difundida e facilmente praticada: "aperte o botão que nós fazemos o resto".

\footnotetext{
${ }^{75}$ Seria interessante conhecer quais eram os produtos disponíveis no mercado de perfumaria e cosméticos indicados para o uso na praia no período. Encontrei referências tanto à busca do bronzeamento perfeito, quanto aos cuidados posteriores com as queimaduras de sol. Para se conseguir uma "pele tostada" recomendava o Anuário das Senhoras em 1949, "é preciso expormo-nos ao sol por longos períodos à torreira do Sol” (p.236); já para os cuidados pós-excesso de sol, a mesma publicação orientava que: "o óleo calcário, produto tão simples como corriqueiro, é o remédio mais eficaz"..
} 


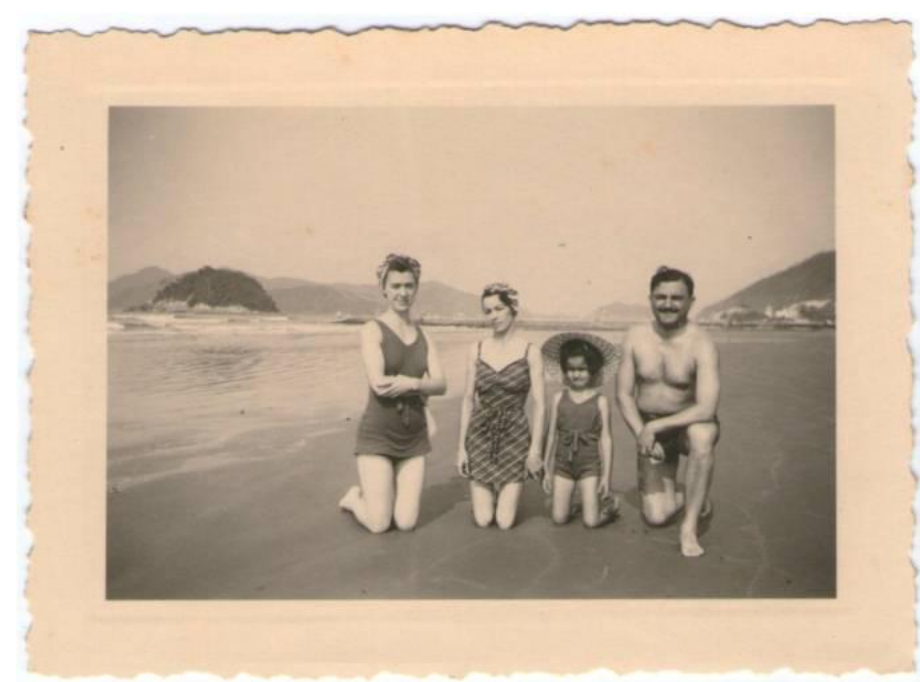

Foto 59: Cleonice e a família Souza na Praia José Menino em 1942. Ampliação das dimensões originais: 6 x 9 cm. Revelação: Papelaria Léo, papel Agfa Lupex.

A proximidade dela com a família Souza é reveladora de aspectos fundamentais das relações sociais que sustentam o lazer. Como ensina José Guilherme Magnani, a “dinâmica do lazer ultrapassa amplamente a necessidade de descanso do tempo de trabalho, possibilitando meios de aprofundamento e reforço de laços de identificação e lealdade que garantem a rede básica de sociabilidade" (MAGNANI, 1996:31). Esse reforço dos laços de sociabilidade é acentuado na medida em que o lugar de lazer encontra-se relativamente próximo do lugar de trabalho possibilitando, uma circulação e uma sazonalidade que permitem, por exemplo, a diversidade na forma de permanência: fim de semana, feriado ou temporada de férias.

Depois de breves dois dias, o grupo retorna à pensão um mês depois e permanece ali durante dez dias produzindo maior quantidade de fotos: foram sete na primeira estada e onze nesta segunda. A foto 60 repete a tomada a distância e de baixo como na foto 56. Porém, não no mesmo ponto da casa, e o olhar fotográfico agora é do Sr. Souza. As portas e janelas altas, a varanda, a escadaria, o jardim, todos esses elementos sugerem que esta casa seria uma das numerosas edificações então construídas em avenidas próximas às praias por ocasião das reformas urbanas. Com a queda das exportações de café, em 1930, alguns dos proprietários sentiram o impacto negativo da crise na economia santista. Resultou imediatamente dessa crise um empobrecimento da cidade. Muitas residências foram então vendidas e ocupadas por pensões e hotéis para veranistas de fins de semana (ANDRADE, 2004) ${ }^{76}$.

\footnotetext{
${ }^{76}$ Texto completo disponível em: http://www.novomilenio.inf.br/santos/h0214.htm Acesso em 22/2/2012.
} 


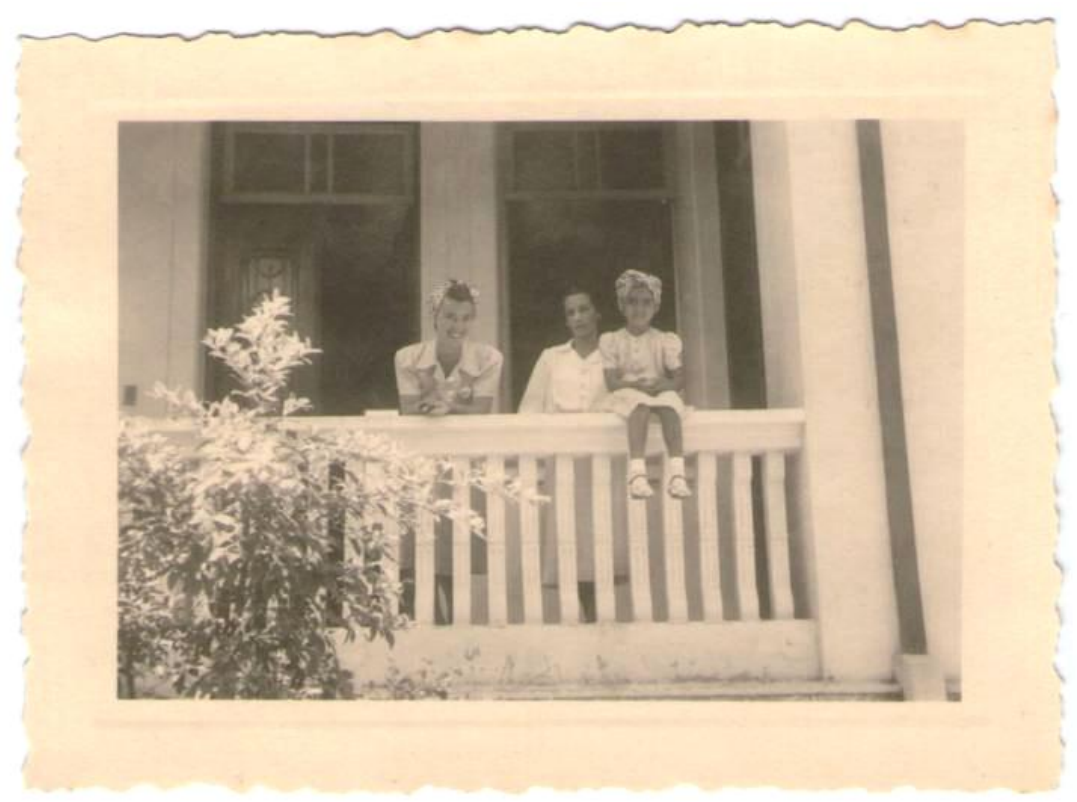

Foto 60: Cleonice a esquerda, Olga e Dircinha. Praia José Menino entre os dias 5 e 15/12 de 1942. Dimensões 6,5x 9,0 cm. Revelação: Papelaria Léo, papel $A g f a$ Lupex.

Nesse segundo passeio, o grupo desfrutou da água, segundo demonstram as imagens. O maiô que Cleonice está usando na foto 61 parece ser o mesmo que ela vestiu nas fotos 25, 26 e 51. É interessante como essa peça de roupa usada em 1936 na praia e em 1939 no Club de Regatas Tietê se desloca em diferentes ambientes. O que a praia demandava então de específico em termos de vestimenta? Pelas imagens encontradas, pode-se afirmar que apenas o roupão felpudo e as toucas de banho. 


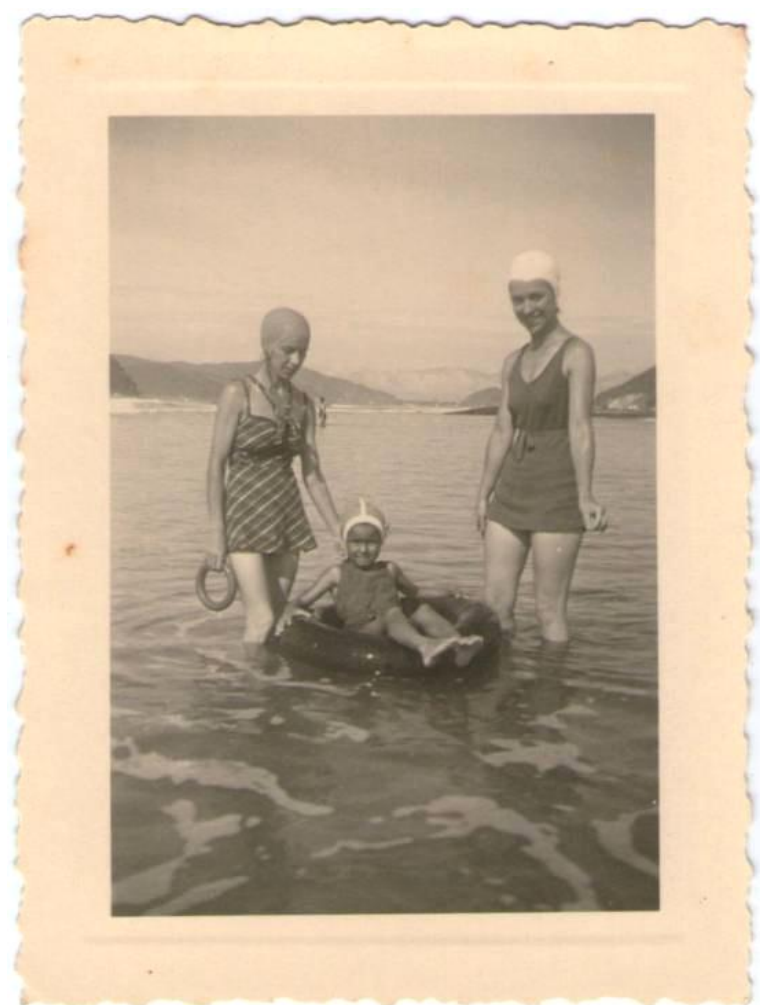

Foto 61: Olga, Dircinha e Cleonice na Praia José Menino entre os dias 5 e 15/12 de 1942. Dimensões 6,5x 9,0 cm. A escolha pela posição vertical da tomada comprime o espaço acentuando a centralidade das figuras. Revelação: Papelaria Léo, papel Agfa Lupex.

Na imagem 62 o grupo é fotografado a pouca distância. Pode ser que esta seja uma das fotos programadas pelo próprio Sr. Souza Filho. É interessante perceber que na imagem a pensão, que se localizava no alto, está agora próxima e a máquina se encontra no mesmo plano que os turistas. Esse segundo passeio implicou uma convivência mais prolongada com os donos da pensão. Era comum às pensões oferecer um ambiente familiar, elas eram em geral negócios de famílias. A despeito da acolhida, o grupo ávido, por novas paisagens e novos alojamentos, nunca mais voltaria a este alojamento; ao menos dela não guardariam mais nenhuma memória fotográfica. A foto 62 parece captar um momento de despedida. 


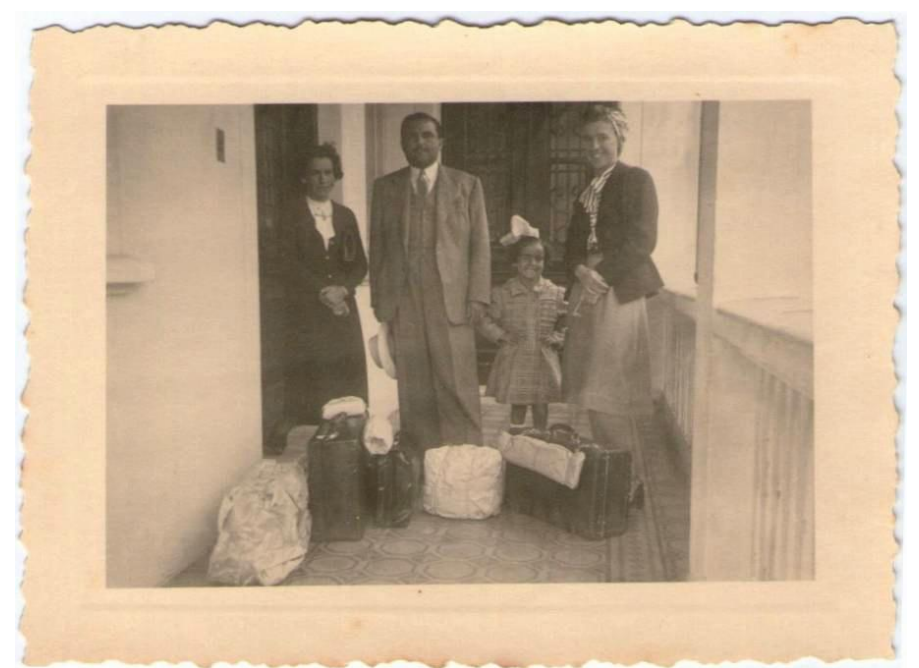

Foto 62: Cleonice à direita sorrindo junto à família Souza na Praia José Menino entre os dias 5 e 15/12 de 1942. Ampliação das dimensões originais: $6,5 \times 9,0 \mathrm{~cm}$. Revelação: Papelaria Léo, papel Agfa Lupex.

A segunda viagem durante o mês de dezembro de 1942, possibilitou a descoberta de outras atrações em localidades próximas à Praia José Menino. Uma destas foi Itanhaém, vila fundada em 1532 por Martim Afonso de Souza e considerada o segundo agrupamento urbano mais antigo do País. A vila recebeu a bênção escrita do arcebispo de São Paulo, Dom José Gaspar, que implorou a Nossa Senhora da Conceição, cuja primeira imagem chegou ao povoado em 1560, que guardasse "para sempre a jóia" que era Itanhaém (SILVA, 1939:46).

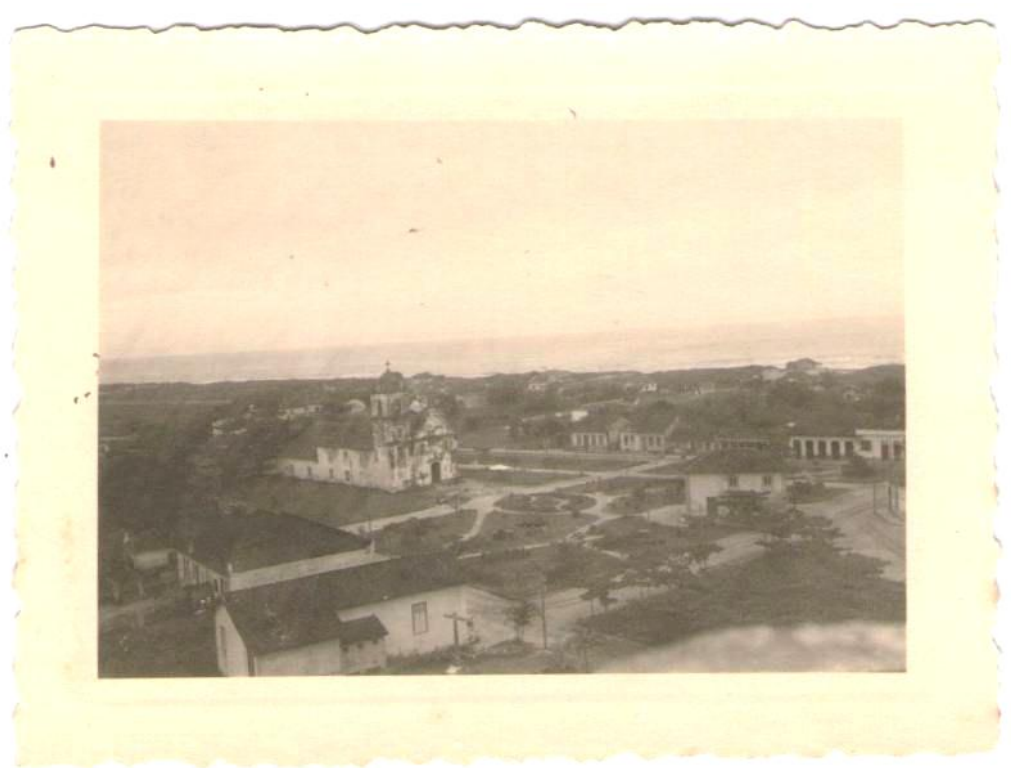

Foto 63: Vista panorâmica da cidade de Itanhaém em 1942. Ampliação das dimensões originais: 6,5x 9,0 cm. Revelação: Papelaria Léo, papel Agfa Lupex. 
A foto 63 apresenta uma Itanhaém semelhante àquela descrita por Dom José. Pode-se ver, ao centro, o importante Convento da Imaculada Conceição erguido sob as ordens de Martim Afonso de Souza, em 1564. A tomada é feita a distância em visão panorâmica e superior, que engloba certa extensão do território da vila exibindo o planejamento urbano e o conjunto arquitetônico. Na legenda de Cleonice trata-se de "Santos - cidade de Itanhaén" 77 . Essa designação da legenda subordina Itanhaém a Santos, quando na realidade já nesse tempo eram localidades distintas. O mesmo Dom José descreve a cidade como sendo seu povo "tão simples e tão pobre" que embora "esquecido" pelo poder público é "patrioticamente apegado às suas tradições, às suas vilas, às suas capelas, às suas devoções" (idem). Entende-se por que o religioso se refere com esses adjetivos à pequena vila, pois em meados de 1940, a Vila de Conceição de Itanhaém era iluminada por lampiões e só algumas ruas por luz elétrica, desligada à meia-noite. $\mathrm{O}$ rio constituía principal meio de transporte e as canoas faziam o papel de charretes e automóveis levando coisas e pessoas (GERODETTI \& CORNEJO, 2001:160).

O grupo se aproxima da cidade e logo é fotografado (foto 64), diante do “Convento em ruínas", que ocupa o centro da imagem.

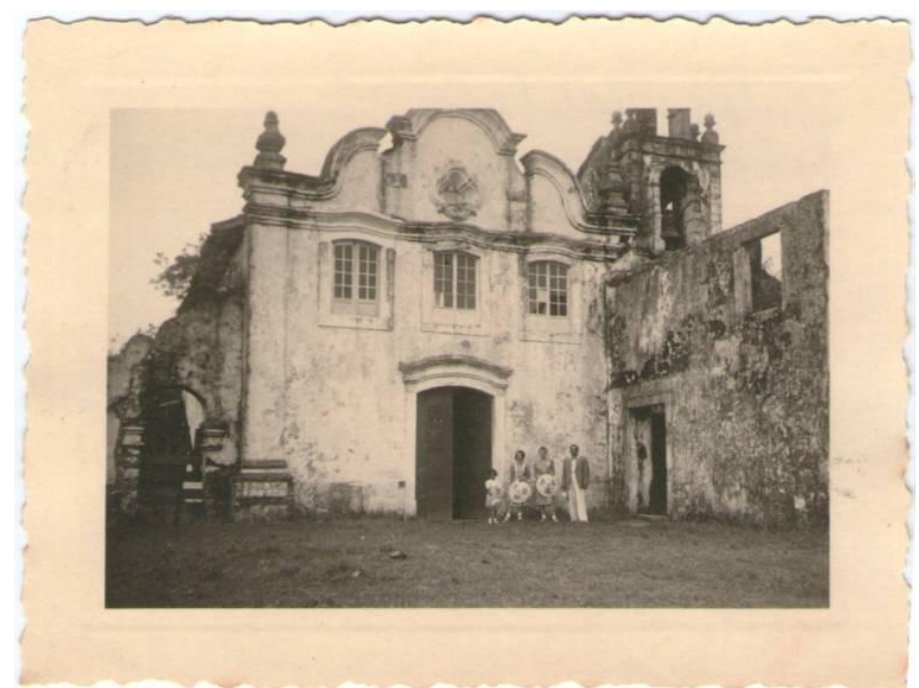

Foto 64: Convento em ruínas, segundo legenda no verso da foto. Itanhaém. Ampliação das dimensões originais: 8 x 6cm. Revelação: Papelaria Léo, papel Agfa Lupex

\footnotetext{
77 A coleção de fotografias que pertenceu a Benedito Calixto de Jesus (Itanhaém - 1853 - São Paulo 1927) contém uma série de imagens desta cidade litorânea, entre as quais, fotos do Convento da Imaculada Conceição. Ver por exemplo IC. 03603 - 0000 - 0000, IC. 03599 - 0000 - 0000 e IC. 1.03437 - 0000 - 0000. Acervo textual e Iconográfico do Museu Paulista da Universidade de São Paulo.
} 


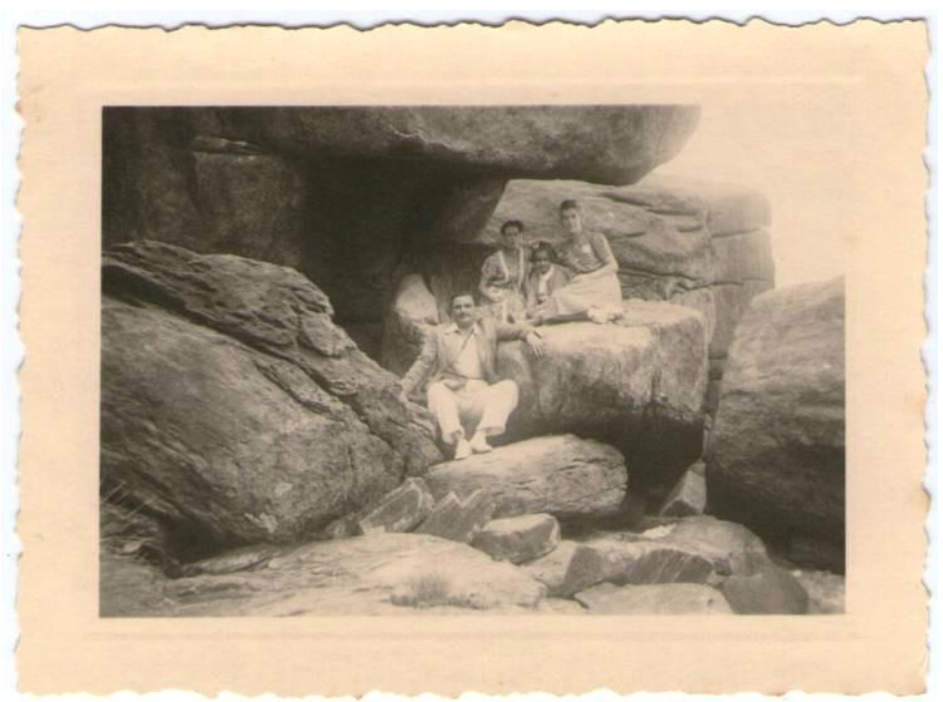

Foto 65: Cama de Anchieta, segundo legenda no verso da foto. Itanhaém - 5-1512-1942. Revelação: Papelaria Léo, papel Agfa Lupex.

Nessa visita a Itanhaém fica evidente um roteiro que percorre a cidade e se detém diante de uma de suas construções mais importantes, ainda que em ruínas. Nesse percurso, não poderia faltar o passeio à pitoresca e célebre "Cama de Anchieta" (foto 65). A "cama" é um conjunto de pedras sobrepostas em degraus onde o grupo se aninhou para um retrato coletivo. Os turistas percorreram o caminho em que os passos de Anchieta, um antigo "usuário" praticante desta paisagem, na feliz expressão de Michel De Certeau (1996), se perderam no tempo em que o padre jesuíta ali esteve. Dessas deambulações jesuíticas sobrou o nome que identifica o espaço e o associa ao descanso dos esforços do padre pela catequização dessas terras selvagens. O local estava longe, portanto, de ser apenas um cenário de fundo para os turistas, possuindo o apelo de uma curiosidade histórica. Como escreve De Certeau: "O que se mostra designa aquilo que não é mais" (1996:189).

Foi possível, pois, notar que a cultura de veraneio se mostrava em franca expansão, criando novos lugares de hospitalidade destinados aos habitantes da capital que podiam pagar por tais serviços. Bertioga como José Menino desenvolverá posteriormente seus próprios alojamentos turísticos. A partir de 1930, a já muito antiga localidade $^{78}$ torna-se Distrito de Paz e, posteriormente, Subprefeitura, permanecendo como distrito de Santos de 1944 a 1991. A partir de 1940, passou a desenvolver suas

\footnotetext{
${ }^{78} \mathrm{O}$ município de Bertioga está localizado no litoral norte do Estado de São Paulo e dista cerca de 108 km da Região Metropolitana de São Paulo, a maior concentração populacional brasileira e o maior polo gerador de turismo, deslocando um considerável contingente populacional para o município em finais de semana e nas férias (SABINO, 2007 p. 15).
} 
funções balneárias. Antes disso, porém, a pequena vila de pescadores não tinha qualquer estrutura para receber viajantes. Ali não havia, nem água encanada, nem luz elétrica e até mesmo a comunicação com Santos era difícil, sendo feita por barcos de pesca, barcos das ilhas e lanchas da Companhia Docas (SABINO, 2008:24).

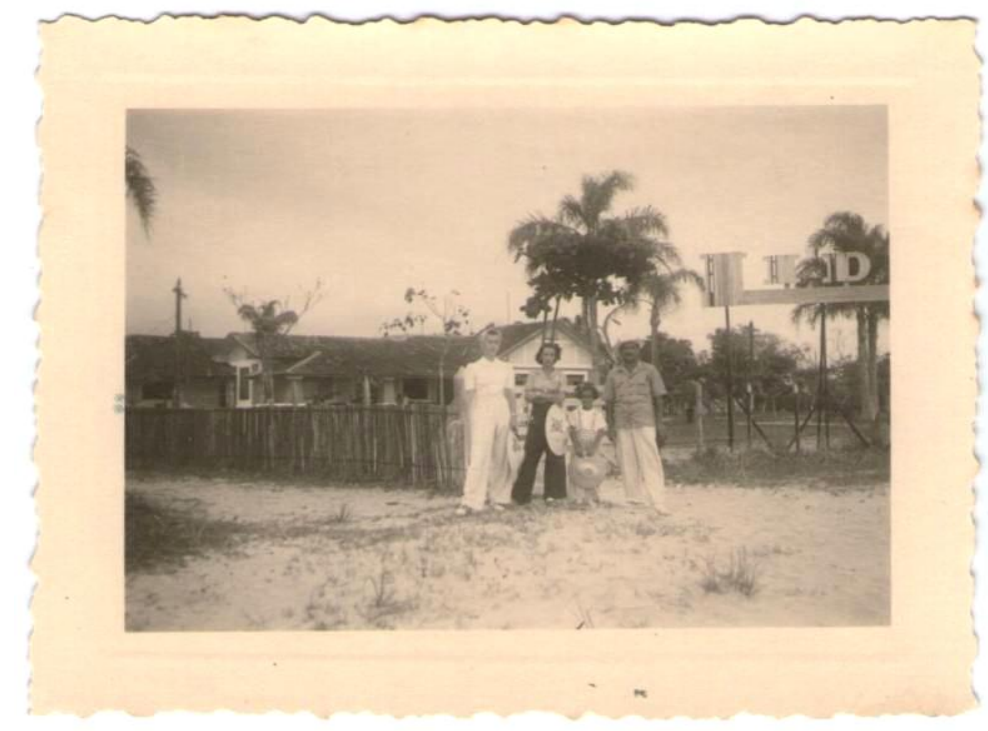

Foto 66: Cleonice e a família Souza no Hotel Lido em Bertioga, 1942. Dimensões: 6 × 9 cm. Revelação: Papelaria Léo, papel Agfa Lupex.

Até 1937 Bertioga contava com "apenas três construções de alvenaria: a Pensão Besser, a Pensão Paulista e a Casa Livino, todas elas com frente para o mar, pois não havia rua" (GERODETTI e CORNEJO, 2001: 135). Em 1940 o Lido Hotel (foto 66) incrementaria o quadro. Pode-se notar a diferença entre a fachada do Lido, e o ambiente em que ele foi instalado, e a pensão Stella Maris. Este hotel, de frente para o mar, foi construído sobre a areia. Sua construção é mais rústica, embora, conforme mostrarei adiante, suas instalações fossem consideradas modernas para a época; trata-se da casa, atrás do grupo na foto 66 acima, o que já permite observar sua diferença em relação à pensão Stella Maris.

O hotel Lido foi inteiramente concebido como um empreendimento hoteleiro pelo “empresário Rafael Costábile, que investiu sozinho uma elevada soma para a construção" (SABINO, op.cit. 27). Ele foi instalado em espaço amplo, o que se pode notar pela foto 67 . 


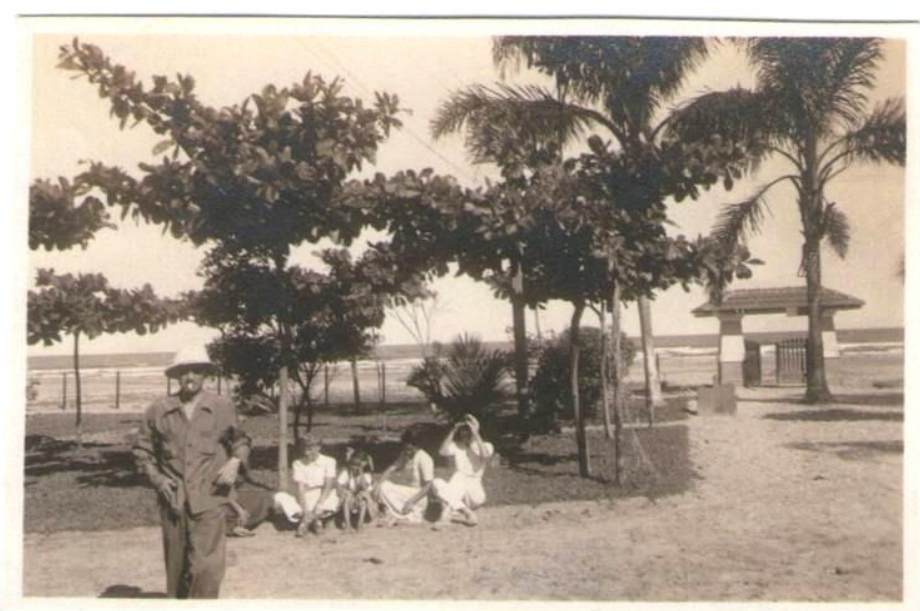

Foto 67: O Sr. Souza na área externa do Hotel Lido em 1945, na segunda visita a Bertioga. Dimensões: 5,5 x 8 cm.

A foto 68, por sua vez, exibe detalhes de uma das faces da construção revelando que o hotel não era tão simples quanto parecia ser na foto 66 , em que a cerca rústica sugere uma falsa precariedade. O grupo hospedou-se nesse estabelecimento duas vezes e, ao observarmos as fotos dos dois momentos, podemos notar diferentes representações do hotel que remetem a diferentes percepções do mesmo espaço. Em 1942, são evidenciados alguns dos atributos da construção que se complementam com as fotos feitas mais tarde. A foto 67 mostra o amplo jardim, enquanto que a foto 68 revela o aspecto doméstico da arquitetura exterior. Com o auxílio da foto 69, contudo, é possível perceber que o hotel era de algum modo "confortável" e pode estar justamente aí sua condição de "moderno", pois ele possuía "frigorífico", "restaurante" "transporte próprio" e "usina geradora de energia elétrica" 79.

79 De acordo com texto sobre Bertioga. Disponível em: http://www.novomilenio.inf.br/bertioga/bh005b.htm Acesso em 12/6/2011 


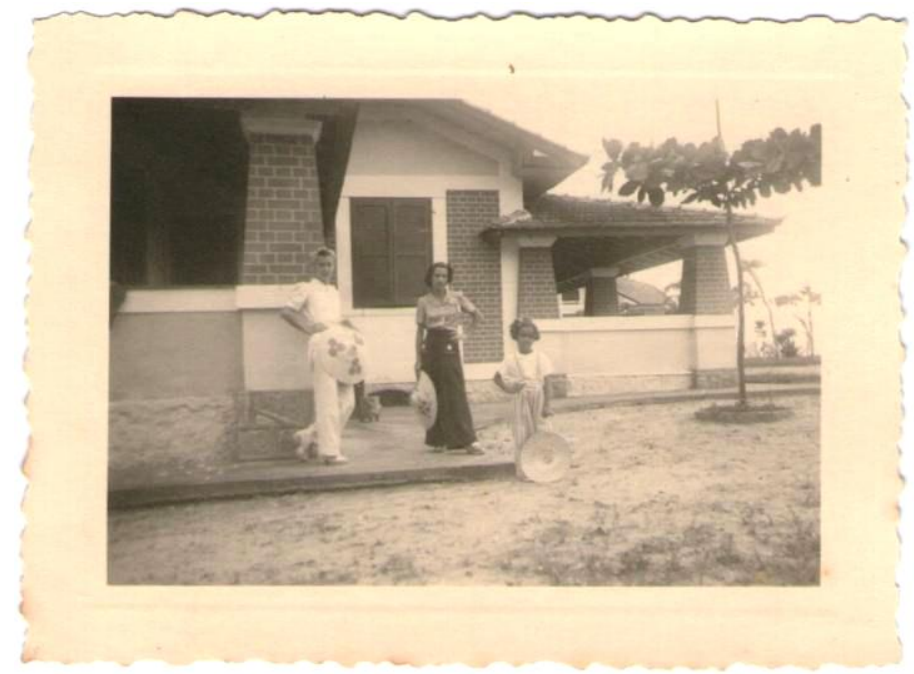

Foto 68: Cleonice à esquerda, Olga no meio e Dircinha no Lido Hotel em 1942. Dimensões: 6 x 9 cm. Revelação: Papelaria Léo, papel Agfa Lupex.

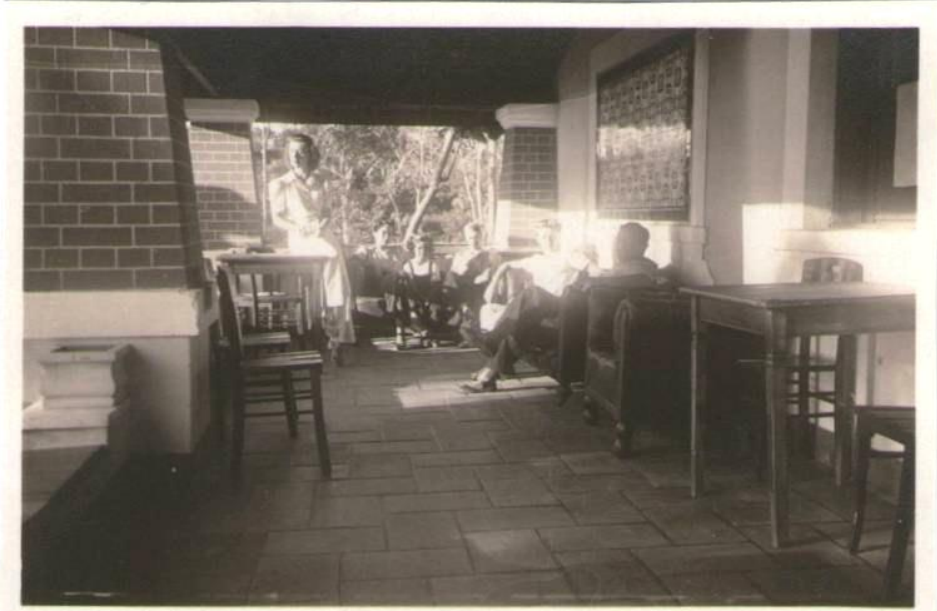

Foto 69: Cleonice à esquerda ao fundo de pé e o Sr. Velloso em primeiro plano sentado no Hotel Lido em 1942. Dimensões: 5, 5 x $8 \mathrm{~cm}$.

O nome Lido foi escolhido possivelmente como uma referência a uma ilha próxima à Veneza, na Itália, como indica outra turista, Lucia Salles Araújo em seu diário de viagem à Europa: "Lido é uma ilha comprida em frente à Veneza" ${ }^{80}$. Tal informação parece relevante, pois a presença de imigrantes nascidos na Europa ou descendentes de europeus, desempenhou um papel importante na formação da cultura balneária praiana, sendo essa ação pioneira traço usual nas práticas recreativas do turismo paulista em razão da quantidade de estrangeiros que se dirigiram para esta cidade.

\footnotetext{
${ }^{80}$ Nome da autora de um diário de viagem pela Europa realizada em 1951 e conservado no Museu Paulista da USP. Coleção Lucia Salles Araújo, ICs. 22812 e 22813. Agradeço a sugestão de Solange Lima para que eu lesse esse diário.
} 
Seguindo uma tendência iniciada pelo Lido, mas que se tornara até certo ponto comum em diversas localidades do litoral, surge, em 1945, A Holandeza, pensão construída por Elza e João Scardini ao lado desse hotel. Na foto 70, aparecem Cleonice e a família Souza incompleta, pois Dona Olga e seu filho pequeno, desta vez, não vieram à praia. $\mathrm{O}$ grupo está diante da fachada da pensão no passeio que fizeram entre os dias 24 e 25 de fevereiro de 1951. O conteúdo da imagem fornece informações sobre os serviços oferecidos pela pensão: "almoços avulsos, produtos da Antarctica e Brahma $^{81 ",}$, então as marcas mais conhecidas de cervejas, refrigerantes e gelo entre Rio de Janeiro e São Paulo. Na placa é informado também o nome completo de sua proprietária: Elza Rosner Scardini.

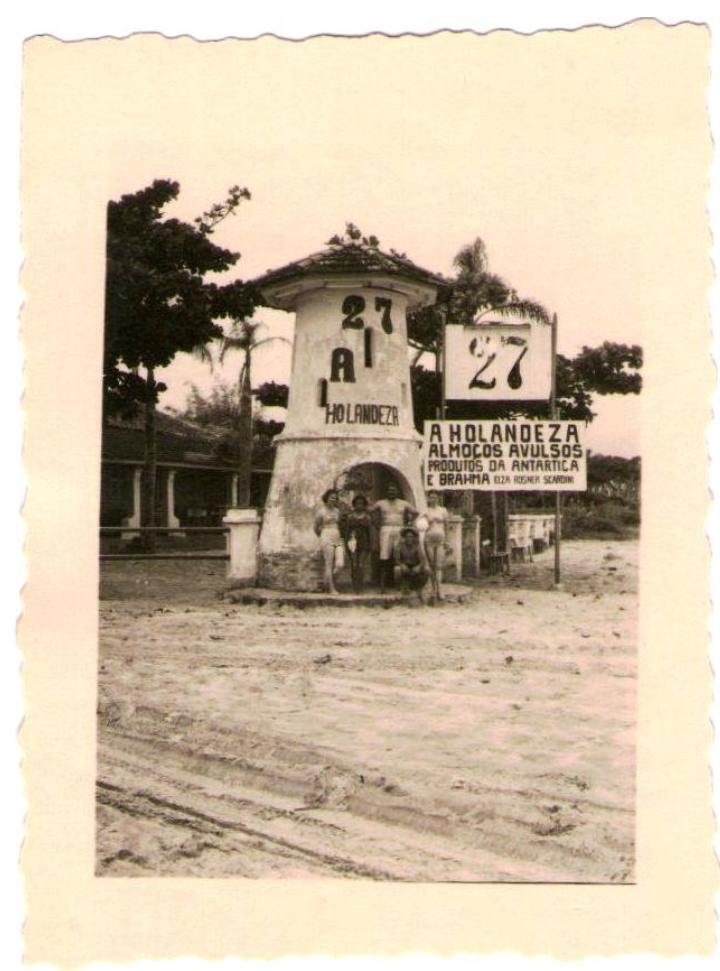

Foto 70: Cleonice e a família Souza em frente da pensão A Holandeza, 1951. Ampliação das dimensões originais: $5 \times 7$ cm.

Pode-se notar que, tal como o Lido, A Holandeza estava instalada diretamente nas areias de frente para o mar (fotos 70 e 71). Tais tomadas fotográficas padronizam a forma de memorizar a experiência de estar em semelhante alojamento, de maneira que o registro da fachada descreve o Lido e a $A$ Holandeza em função dos mesmos códigos

\footnotetext{
${ }^{81}$ Não é possível, em razão das limitações de tempo, relacionar todos os indícios encontrados seja na imagem ou no suporte fotográfico como, por exemplo, das duas marcas de cerveja que aparecem na foto. Para uma história de ambas marcas ver: http://www.cervejasdomundo.com/Brasil3.htm Acesso em 24/2/2012. O site especializado em cervejas narra a história e a evolução da bebida no Brasil.
} 
visuais: o fotógrafo mantém uma certa distância a fim de dar conta do tamanho do estabelecimento. O grupo perde um pouco de sua importância como motivo da imagem, ao passo que a arquitetura e o espaço circundante ganham destaque. Fotografar-se diante desses estabelecimentos é a prova que eles ali estiveram e, tais registros qualificam e descrevem melhor os espaços do que as pessoas, embora elas estejam ali o tempo todo.

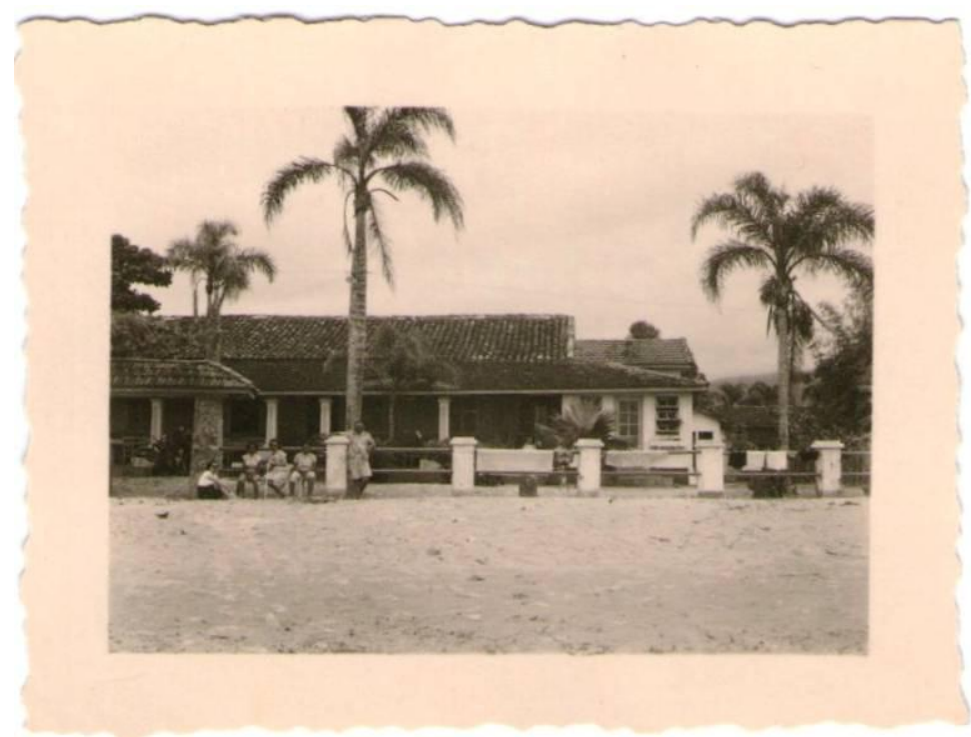

Foto 71: Fachada da pensão A Holandeza em 1951. Ampliação das dimensões originais: $5 \times 7 \mathrm{~cm}$.

Mas parecia importante não se limitar à fachada do estabelecimento, que se gabava de propiciar aos hóspedes o "máximo sossego" (GIRODETTI \& CORNEJO, 2001: 135). Assim é que a foto 72 propicia uma noção do espaço de convivência social na área construída da casa, com poucas mesas enfileiradas onde o grupo ocupa aquela que se encontra ao fundo. A escolha pelo formato vertical na tomada do registro acentua a profundidade do motivo - um corredor largo com quatro mesas - e destaca elementos construtivos, como a madeira da parede em oposição aos pilares de sustentação do corredor, por certo feitos de tijolos. 


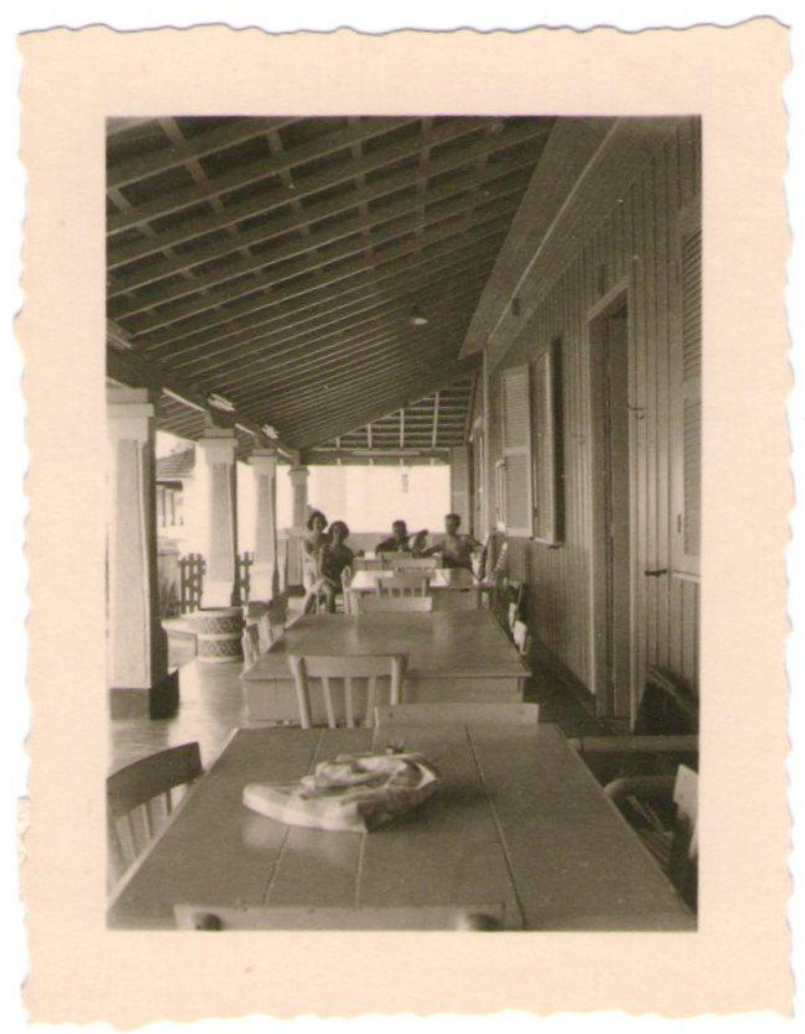

Foto 72: Corredor com mesas na pensão A Holandeza em 1951. Ampliação das dimensões originais: $5 \times 7 \mathrm{~cm}$.

Quanto ao tipo de arquitetura dos dois alojamentos: trata-se de construções que, guardadas as diferenças, remetem ao ambiente de uma casa de família, atendendo a uma clientela que não possuía uma segunda residência litorânea: "artesãos, profissionais liberais e comerciantes utilizando pensões e hotéis" (SEABRA 1979:16). Parte do conforto e do sossego destes empreendimentos relacionava-se ao fato da gestão das pensões ser feita de maneira familiar e artesanal, enquanto unidade de prestação de serviço, integrando todas as funções da hospedagem (refeições, lanches). Seus proprietários conviviam com os hóspedes (idem p. 30). Esses espaços fundamentais de acolhimento de turistas, constituirão padrões infraestruturais a serem copiados por alojamentos posteriores, seja na forma material, seja como norma das acomodações que os veranistas esperavam receber nos destinos turísticos.

O subdistrito de Bertioga ainda anexado a Santos estava se transformando para atender aos turistas que saíam da capital. O interesse crescente pelos arredores santistas se relaciona, suponho, a diversificação dos destinos litorâneos e à fruição das paisagens disponíveis do extenso litoral paulista. Essa diversidade fundamentava o olhar do turista consumidor de paisagens. Por conseguinte, as diferenças entre lugares ganharam 
enorme importância. Bertioga não oferecia a mesma infraestrutura urbana que Santos, porém proporcionava aos turistas a sensação de um contato mais direto com a natureza devido à proximidade entre os espaços construídos e o espaço natural. $\mathrm{O}$ deslocamento para Itanhaem ou Bertioga daqueles que desejavam fugir da movimentação de Santos representava uma opção apreciada de repouso em cenário pitoresco

Para alcançar semelhantes destinos era necessário utilizar uma das duas barcas diárias de propriedade da Companhia Santense de Navegação. A empresa fazia o serviço de transporte regular entre Bertioga e Santos saindo do Armazém no 5 da Companhia Docas de Santos (GERODETTI \& CORNEJO, 2001:135). A foto 73 mostra o trajeto da volta a Santos. A tomada permite observar a paisagem que vai sendo deixada para trás. A visão monocular da câmara fotográfica fixa definitivamente a transição entre o sossego temporário do destino e a urgência do retorno. O fotógrafo contempla a paisagem, mas inclui no enquadramento parte da cabeça de alguém no canto inferior direito. Ambos fazem a travessia de volta à vida prática. Essa imagem evoca a ideia de paisagem turística como algo partilhado, mas as fotos ora revelam, ora omitem a presença de outras pessoas no mesmo ambiente. Não houvesse legenda, dificilmente poderíamos acreditar que se trata de vista tomada a partir de um veículo aquático.

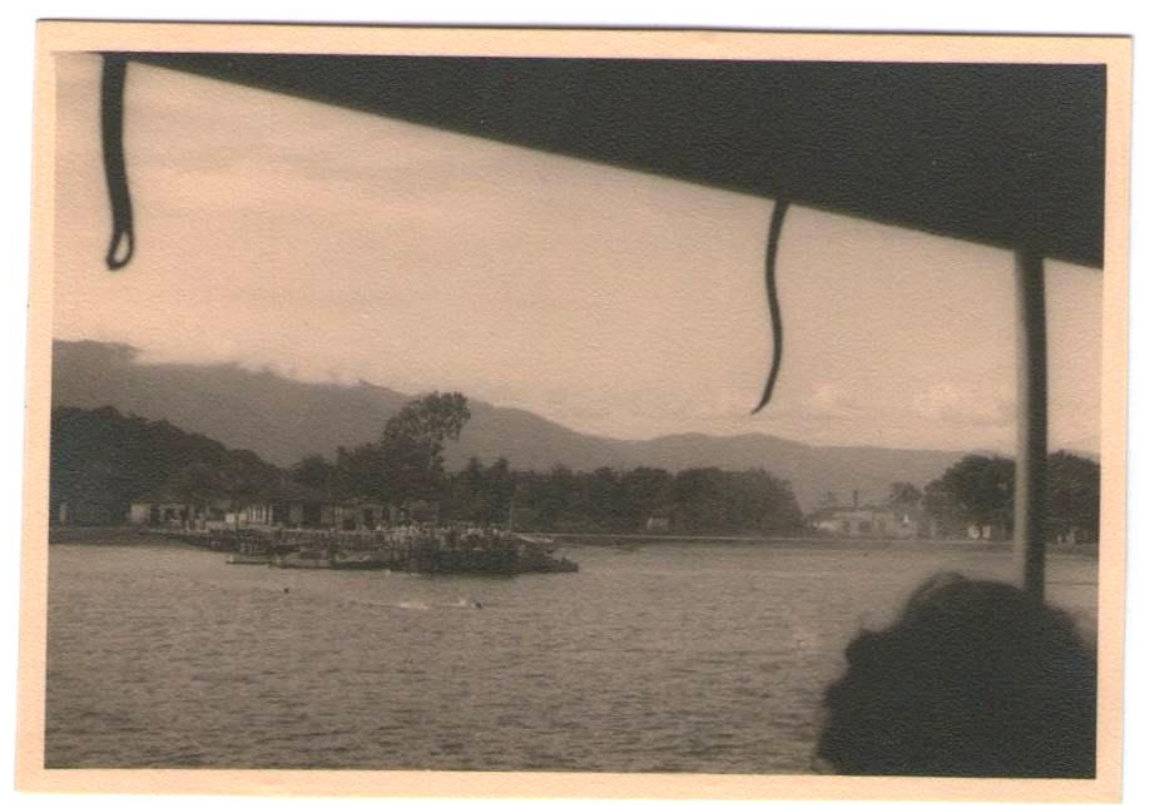

Foto 73: Bertioga, volta a Santos (legenda original). Ampliação das dimensões originais: 6,5 x 9,5 cm. Revelação: Laboratório da FOTOPTICA. 
As condições infraestruturais das viagens turísticas estavam melhorando, segundo as imagens da coleção. Algumas em especial mostram inovações realizadas em lugares como Bertioga - dona de passado glorioso, mas adormecida no tempo. Semelhantes localidades convertidas em destinos turísticos recebem camadas médias urbanas e consumidores de praias e mares como os comerciários que, a partir da fundação do SESC Bertioga, começam a frequentar o lugar, em função do recente benefício das férias remuneradas.

\title{
2.5. O SESC Bertioga
}

\begin{abstract}
É de meu dever comunicar-vos do triste $e$ desencorajador fenômeno a que fora forçado presenciar nesta colônia de férias. Trata-se da desumana crueldade com que o tempo implacável torna os dias aqui vividos tão curtos e efêmeros quão belos e inesquecíveis para todo o sempre! Agradecem sinceramente, Betty Jordan e Fred Jordan, Bertioga, 19 de agosto de $1950^{82}$.
\end{abstract}

Nenhum empreendimento hospitaleiro causaria em Bertioga o impacto que a colônia de férias Ruy Fonseca iria promover. A opinião do casal Jordan acima mencionada expressa o sentimento um tanto melancólico de visitantes que ali estiveram nos primórdios das atividades da colônia de férias. O ponto de vista do casal, para quem o tempo é o vilão da estória, deixa entrever a disputa dos comerciários para visitarem a colônia nos primeiros dois anos de funcionamento. Eles estavam certos em lamentar a implacável rapidez do tempo de descanso onde a infraestrutura oferecida era inigualável.

Inaugurada dois anos após o início das atividades do SESC na capital paulistana, a Colônia de Férias "Ruy Fonseca", erigida na Praia da Enseada, trouxe grandes mudanças ao cenário balneário desse distrito santista" ${ }^{\text {"83 }}$.O surgimento deste SESC relaciona-se à questão das férias remuneradas do trabalhador da indústria e comércio

\footnotetext{
${ }^{82}$ Revista O Sesc em Marcha, set/out. 1950, p. 3. Acervo GEDES SESC Memórias.

83 O nome da colônia é uma homenagem a um "grande comerciante depois de ter sido pequeno comerciário Ruy Fonseca uniu em sua biografia duas categorias de cidadãos estruturadores da constituição do SESC, daí sua passagem de pequeno comerciário a grande comerciante e, mais tarde, celebrado como uma efeméride. Seu nome seria para sempre lembrado como "inesquecível companheiro, tão bruscamente arrebatado do nosso convívio n'uma expressiva e justa homenagem a quem tanto fez pelos comerciários", como indica o Relatorio Anual do Departamento Regional do Serviço Social do Comércio 1947/48. Revista O Sesc em Marcha, maio/junho 1949, p. 3 Acervo GEDES SESC Memórias.
} 
(DINES, 2007:86). Na realidade, tal preocupação estava associada a uma forma, então nova, instituída pela iniciativa particular em tratar o comerciário e sua família como seres humanos e não como criaturas que se possam manejar por meio de disposições físicas e pecuniárias (MORSE, 1954:248-249). Com efeito, instituições como o SESC ligadas ao lazer, à assistência social, à saúde do trabalhador e à sua família, ou o SENAI, cuja finalidade era dar aos jovens trabalhadores habilitações profissionais, atendiam a um interesse mais amplo de trazer a "paz social" por meio da organização de tais empreendimentos.

No item IX do relatório administrativo produzido pelo SESC, referente ao ano de 1947, figuram os motivos pelos quais a instituição particular de interesse social criou a colônia de férias:

\footnotetext{
Compreender a grande necessidade que tem todo o trabalhador de um repouso anual para recuperação das energias gastas no árduo labor quotidiano - e considerando, outrossim, que esse repouso anual, hoje universalmente reconhecido como um direito - deve ser o quanto possível proporcionado ao beneficiado em lugar diverso em clima diferente daquele em que o mesmo trabalha - e por outro lado verificando que as condições econômicas do comerciário raramente lhes permitem fazer face as grandes despesas de viagens e hospedagens cujos preços são hoje elevadíssimos como decorrência natural da carestia geral - deliberou o Conselho Regional do SESC a instalação de uma Colônia de Férias (grifos meus). ${ }^{84}$
}

Este documento revela uma imagem do momento social pelo qual a cidade de São Paulo estava passando nos anos imediatamente posteriores à Segunda Guerra. O texto mostra que havia um lazer organizado para poucas pessoas, daí o impacto positivo dessa ação modernizadora das relações de trabalho. Vale ressaltar a ideia de um lazer especializado que tem no verão, sol e brisa marinha o "clima diferente", ingredientes fundamentais para o descanso do trabalhador comerciário.

A cidade de São Paulo era nesse momento o maior parque industrial da América Latina, fato que produzia na vida social de muitos de seus habitantes grandes desigualdades, e que o SESC com sua ação social dirigida pretendia atenuar. A pretensão da instituição era participar do contexto internacional de reconhecimento do direito às férias anuais remuneradas. Nesse sentido, o Serviço Social do Comércio buscava cumprir - até com certa antecipação - a Resolução no 217 A (III), artigo 24, da Assembleia Geral das Nações Unidas proclamada em 10 de dezembro de 1948 e assinada pelo Brasil na mesma data, que afirma: "Toda pessoa tem direito a repouso e

\footnotetext{
${ }^{84}$ Acervo GEDES SESC Memórias.
} 
lazer, inclusive a limitação razoável das horas de trabalho e a férias periódicas remuneradas" 85 .

Marc Boyer (2003: 104) informa, contudo, que o Brasil, desde meados dos anos 1930, já concedia férias pagas, tanto quanto países como França, da Europa Central, Escandinávia, Portugal, Venezuela e Chile. Todavia, ter o direito a férias remuneradas não significava gozá-las em clima diferente e lugar diverso. O preço dessa modalidade de lazer era inacessível a grande massa da população. O ritmo acelerado da urbanização e da industrialização não tinha sido acompanhado pela criação de atividades e infraestrutura recreacionária para os trabalhadores paulistanos.

Para Cleonice não havia qualquer novidade em passear e conhecer lugares novos na praia. De maneira que ir à colônia pode ter sido uma experiência nova em termos do contato com uma estrutura até então inédita no país, que reunia um complexo de benefícios. Por outro lado, não havia surpresa quanto ao comportamento esperado em espaços de recreação balneária como este, uma vez que, desde pequena, ela tivera contato com esse tipo de ambiente, ou seja, foi se socializando, aprendendo o gosto da paisagem, da contemplação da natureza, da experiência com a água salgada. Já na vida adulta, ela podia frequentar os espaços litorâneos por conta própria, porém, talvez não sozinha. Cleonice, uma "comerciária", e também a família Souza, cujo chefe de família era "comerciante", diversificaram os lugares que já conheciam no litoral.

Como "relatos de espaço" (DE CERTEAU, 1996), as fotos revelam o ambiente pensado pelo urbanista Prestes Maia, mas praticado por atores precisos. O paisagismo envolve o grupo nesse espaço exclusivo de uma classe produtiva. $\mathrm{Na}$ foto 74 , o jardim em primeiro plano sugere uma separação entre quem está dentro - o grupo - e quem está fora do enquadramento - o fotógrafo momentaneamente separado para fazer a tomada. Ao fundo, observa-se O SESC cuja estrutura física é muito semelhante, todavia bem maior que o modelo arquitetônico horizontal de alojamento representado pelo Hotel Lido e a pensão A Holandeza.

\footnotetext{
${ }^{85}$ Texto completo 


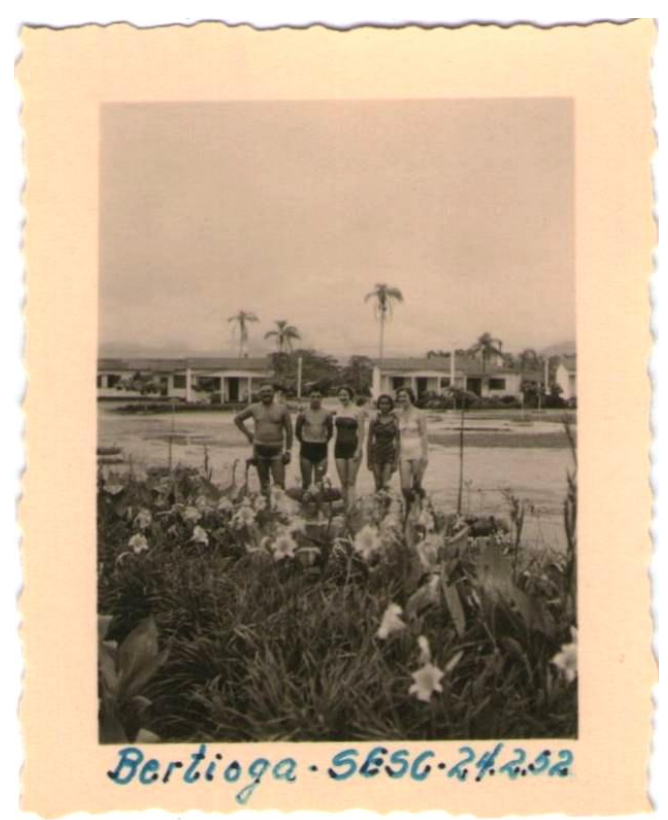

Foto 74: O Sr. Souza à extrema esquerda e Cleonice à extrema direita ao lado de Dircinha no SESC Bertioga em 1952. Ampliação das dimensões originais: $5,5 \times 6 \mathrm{~cm}$.

O dia 24 foi, ao que parece, inteiramente desfrutado nos limites da colônia, isto é, o grupo não foi fotografado na praia, embora esta fosse "um dos lugares mais salubres do litoral paulista com um coeficiente mínimo para não dizer nulo de casos de implaudismo" $"$, conforme o Relatório Anual do Departamento Regional do Serviço Social do Comércio 1947-1948. Na segunda visita à colônia também não houve referências à praia. A natureza que cerca a colônia é bela e convida ao repouso ${ }^{87}$. Esse planejamento espacial do SESC pode ser visto também na foto 75, na qual cada palmeira aparece plantada em lugar demarcado por um vaso circular. Na imagem, o grupo aparece descentralizado como uma massa discreta na composição. Cleonice, à extrema direita, e Dircinha permanecem, uma ao lado da outra como na foto anterior.

\footnotetext{
${ }^{86}$ Segundo o dicionário Caldas Aulete (ma. lá. ri: a) 1. Med. Infecção causada por protozoários do gênero Plasmodium transmitida pela picada de mosquitos do gênero Anopheles, e que se caracteriza por calafrios e febre. [F.: Do it. malaria 'ar insalubre] Disponível em: http://mob.aulete.com.br/site.php?mdl=aulete digital\&op=loadVerbete\&pesquisa=1\&palavra=mal\%E1ria Acesso em 28/11/2011.

${ }^{87} \mathrm{O}$ termo repousante/repouso/repousar é uma constante nas referências feitas à colônia. Um bom exemplo pode ser encontrado na Revista do Comérciário - Ano I - janeiro de 1956 - $n^{\circ}$ 1, p.6. Acervo GEDES SESC Memórias.
} 


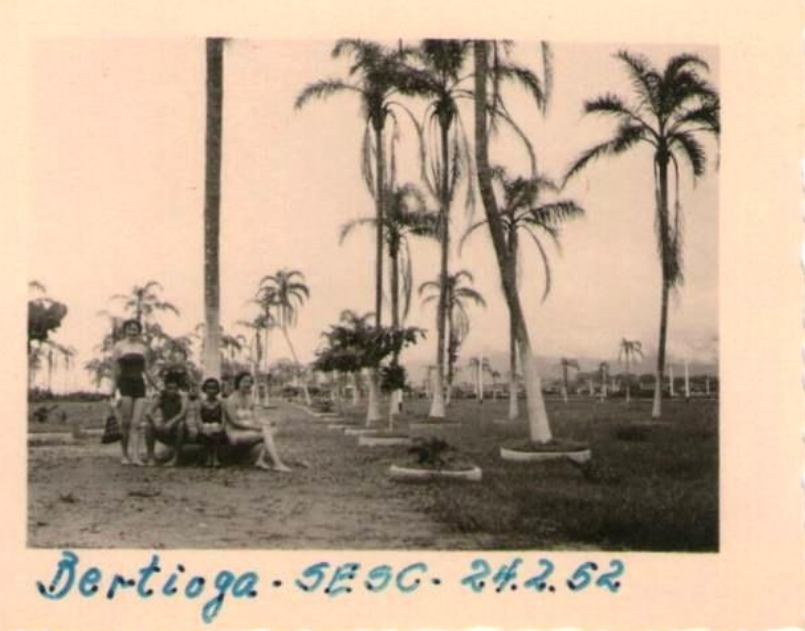

Foto 75: Anônimos, Dircinha e Cleonice no SESC Bertioga em 1952. Ampliação das dimensões originais: 5,5 x 6 cm.

É certo que uma das preocupações do SESC, quando construiu as instalações, era não só de proporcionar repouso ao corpo físico, mas também ao espírito dos comerciários. À folha 36, o Relatório administrativo de 1948 pronuncia-se sobre a capela (foto 76), “construída em aprazível recanto da colônia, artisticamente decorada pelo pintor Antonio Paim ${ }^{88}$, e cuja padroeira - Nossa Senhora dos Prazeres - domina a respectiva nave".

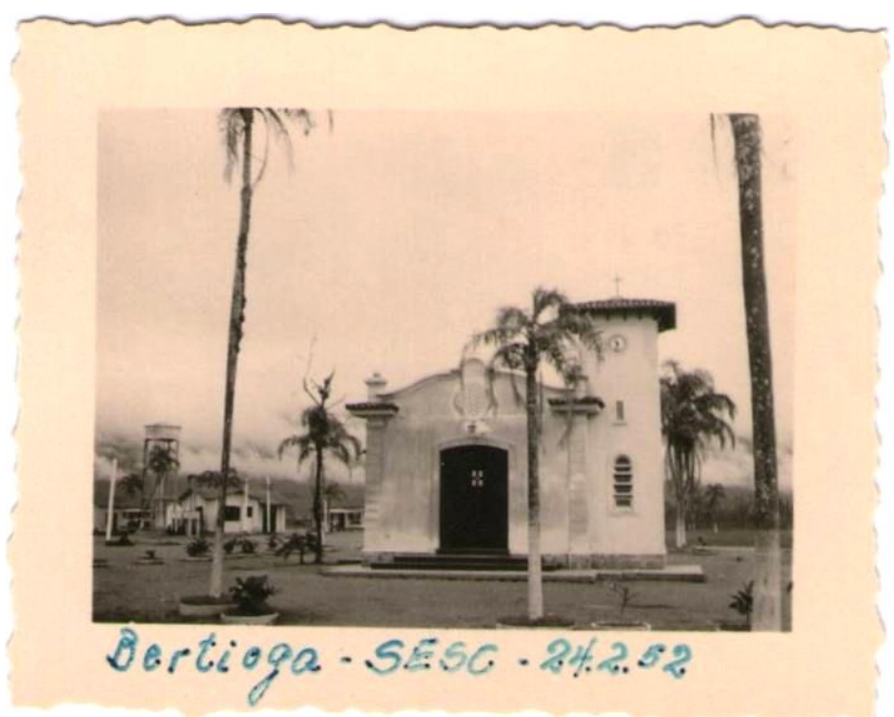

Foto 76: Capela construída no SESC Bertioga, 1952. Ampliação das dimensões originais: $5,5 \times 6 \mathrm{~cm}$.

\footnotetext{
${ }^{88}$ Ver a respeito da obra do pintor Antonio Paim (1895-1988), TARATANSHI, 1988: 1-10.
} 
Contudo, a capela tal como aparece na foto 76 não parece ter sido um ponto de parada estimulante para o grupo. Talvez a imagem da pequena igreja soasse um tanto pitoresca naquele contexto mais mundano de prazer e diversão: pode ter vindo daí o motivo do registro.

O interesse pela diversidade dos motivos fotogênicos, capela, jardim com palmeiras (foto 75) ou pose grupal tendo o jardim em primeiro plano (foto 74 ), parece relacionar-se àquilo que Jhon Urry afirma baseado nas reflexões sobre a natureza da fotografia formuladas por Susan Sontag:

A fotografia dá uma forma à viagem. É o motivo para se parar, tirar uma foto - clique! - e prosseguir. A fotografia implica obrigações. As pessoas sentem que não podem deixar de ver determinadas cenas, pois caso contrário, as oportunidades de fotografá-las serão perdidas (URRY, 1999: 187).

O fotógrafo recolhe cenas e situações reveladoras de como cada um dos membros do grupo define sua posição nas fotos em razão das afinidades ou obrigações de parentesco. O Sr. Souza Filho, por exemplo, aparece à esquerda nas fotos 74, e 77. Dircinha está ao lado de Cleonice nas fotos 74,75, e entre Cleonice e o Sr. Souza Filho na foto 77. Junto a pequenas variações estruturais no ambiente, os modelos incorporam outras poses, mas nem sempre outras posições. A grandeza espacial da colônia de férias se fragmenta em quadros distintos uns dos outros, mas unificados narrativamente pela legenda como fotogramas de um filme, como partes de um relato no qual se escolhe o que merece destaque para se tornar memória.

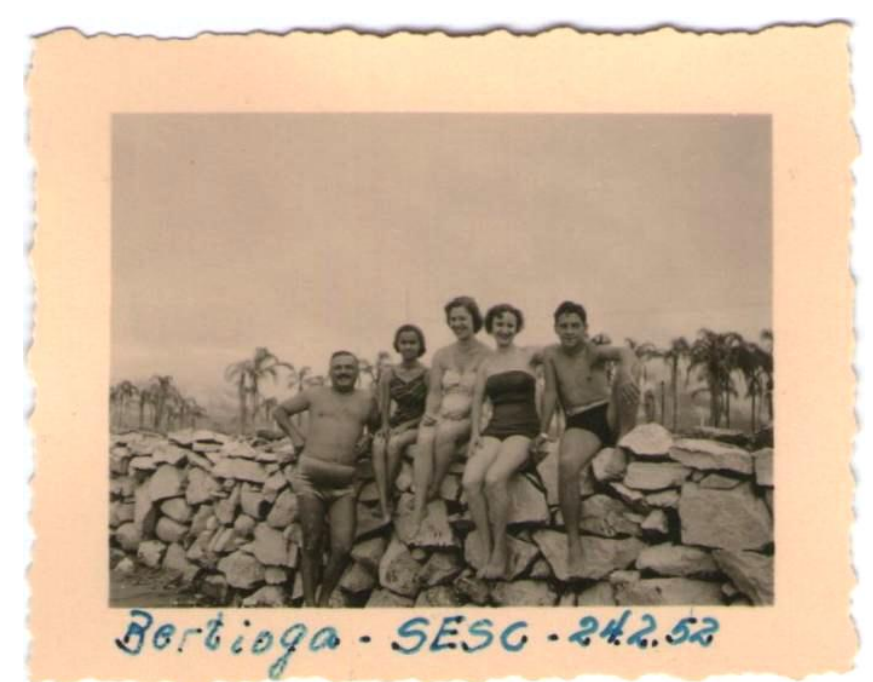

Foto 77: O Sr. Souza à extrema esquerda, Dircinha, Cleonice e anônimos no SESC Bertioga em 1952. Ampliação das dimensões originais: 5,5 x $6 \mathrm{~cm}$. 
A miniaturização do espaço real permitido pela fotografia torna a memória da experiência do passeio algo portátil que pode ser transportado, reproduzido, presenteado ou simplesmente guardado em álbuns soltos, nos quais as imagens resultantes ficam armazenadas em caixas de papelão. A fotografia recorta e reduz o terreno de 350 metros de frente para o mar por 2.500 metros de fundo. Inicialmente, essa área pertencera ao Dr. Luiz Antonio de Assumpção, que vendeu posteriormente mais 30 metros ao SESC. O empreendedor Raphael Costábile, proprietário do Hotel Lido, vendera 136 metros à mesma instituição. Essa compra revela a dinâmica de negociação daocupação do espaço litorâneo por agentes sociais que foram, ao longo do tempo, empreendendo mudanças nesses lugares e construindo sua vocação balneária.

Muitos desses homens saíam da capital do estado e acorriam à costa para inventá-la como ambiente propício aos novos tempos do país. Apesar do contexto de crise do pós-guerra, suas atividades expressavam também otimismo e a crença na mudança e no progresso nacional. Materializada em estabelecimentos como a colônia de férias. As imagens de Cleonice confirmam o impacto da transformação da paisagem no qual predominam ângulos pedestres, normalmente centrados em atividades do grupo e sem qualquer vista panorâmica ${ }^{89}$. Pode-se afirmar que não havendo nos limites da colônia uma paisagem natural exuberante - como aquelas encontradas no campo, por exemplo - o fascínio dos turistas fixava-se na área construída.

Nesse contexto, as preocupações com a economia do tempo livre estavam ainda em seus primórdios e planejar ações em favor do lazer era tarefa urgente assumida pelo sistema S: SESC, SENAI e SESI. As contradições do momento necessitavam, pois, de planejamento $^{90}$. Sob esse aspecto os autores do Relatório de 1947/1948 mostram que a colônia, uma grande obra de remodelação do espaço da "praia da Bertioga", conta com a "preciosa colaboração" do "grande urbanista Prestes Maia". O fato do antigo prefeito de São Paulo ser colaborador da obra diz muito a respeito da modelagem desse espaço, criado segundo os interesses da indústria e comércio paulista. Lembremos que Prestes Maia elaborou também os planos de urbanização de Campos do Jordão, de Santos e de Campinas.

\footnotetext{
${ }^{89}$ Ao manipular as revistas do SESC no período entre 1948 e 1959 sobram, ao contrário, visões panorâmicas e abrangentes que revelam o olhar institucional em contraste com as visões amadoras guardadas na coleção Cleonice Maria Heine.

${ }_{90}^{9}$ Essa ideia de projeto e planejamento aplica-se ao caso do urbanismo nascente em São Paulo a partir do fim da Segunda Guerra. Ver: LAMPARELLI, (1994:12).
} 
Prestes Maia, Cleonice e a família Souza, contemporâneos de ações como a construção do SESC provinham da capital. Ao contrário do prefeito planejador, entretanto, a jovem e os Souza praticaram tais espaços, caminhando através deles e parando, aqui e ali, para a realização de imagens fotográficas. As fotos, uma vez legendadas, indicam pontos de parada, instantes de clique. Os locais visitados ganham configurações tão inéditas quanto a instantaneidade das fotos; eles emergem nas imagens, o que é reforçado pelas legendas que visam à identificação do lugar e do tempo, mais do que da situação fotografada. Em conjunto, esses sítios compõem um circuito social complexo que emerge de uma experiência social particular. Sua cartografia emergiu através da busca das relações que as fotos mantêm entre si. Ao aproximar ideias aparentemente distantes como o urbanismo de Prestes Maia e as deambulações de Cleonice por uma série de lugares, penso no quanto as imagens legendadas sublinham para o pesquisador a importância de situá-las no âmbito da sociedade que forjou as condições do consumo visual (fotografias) e as oportunidades para apreciar paisagens (passeios e viagens). Há uma circulação, portanto, de coisas, símbolos, pessoas, saberes práticas e representações sociais que se deslocam pela capital, pelo litoral e pelo campo, qualificando esses lugares e gerando novas formas de sociabilidade.

Cleonice e a família Souza, agora completa, retornaram a essa Colônia de Férias em 1959. A visita gerou apenas três fotos, duas das quais ( fotos 78 e 79) são aqui exibidas. O sistema de legendagem continuou o mesmo, no espaço da moldura, porém, na foto 79 surge a expressão "Colônia de férias", produzindo pequenas diferenças na identificação e classificação da imagem. 


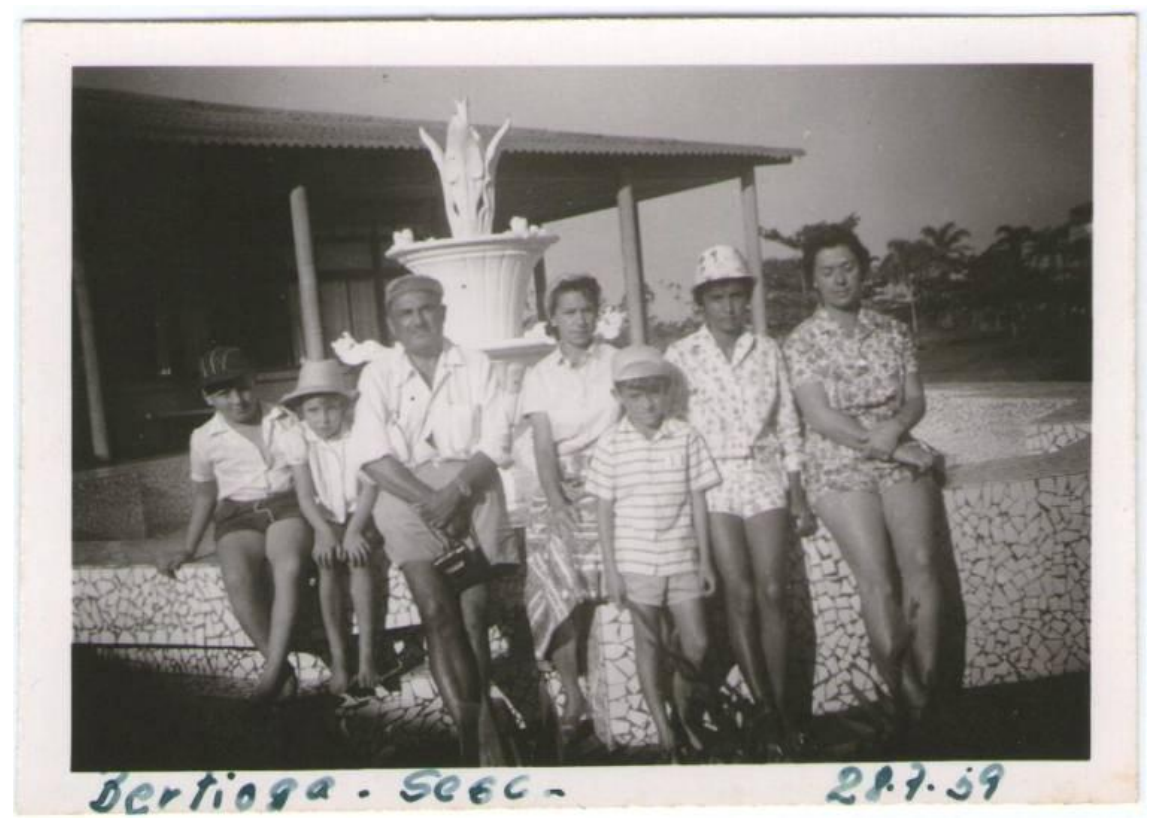

Foto 78: À esquerda crianças não identificadas ao lado do Sr. Souza, Dona Olga, o filho anônimo, Dircinha e Cleonice à direita em uma área aberta do SESC. 28-7-59. Dimensões: $9,5 \times 7 \mathrm{~cm}$.

Outra diferença perceptível é que ninguém aqui está com trajes de banho, são também outros os espaços descritos em relação a primeira visita.

Já na foto 79, Cleonice e Dona Olga, que se conheciam há pelo menos dezessete anos, estão em repouso sob a luminosidade que preenche o espaço amplo entre colunas planejado para os usuários do local: os comerciários e suas famílias. Ao contrário de Cleonice, Olga encara a máquina de captar instantes. As crianças, que vão cada vez mais se socializando com a presença do equipamento posam educadamente, distribuindo-se bem na composição triangular. Os meninos mantêm os braços para baixo, enquanto a menina descansa o braço esquerdo sobre a cintura. A luminosidade intensa toma quase todos os rostos subestimando as expressões faciais. Apenas o pequeno filho dos Souza está protegido da luz direta. Esta imagem capta o clima que cerca as fotos de família, superfície sobre a qual diferentes gerações convivem harmoniosamente, apesar das marcas diferenciais cronológicas (MENEZES, 1999:14). 


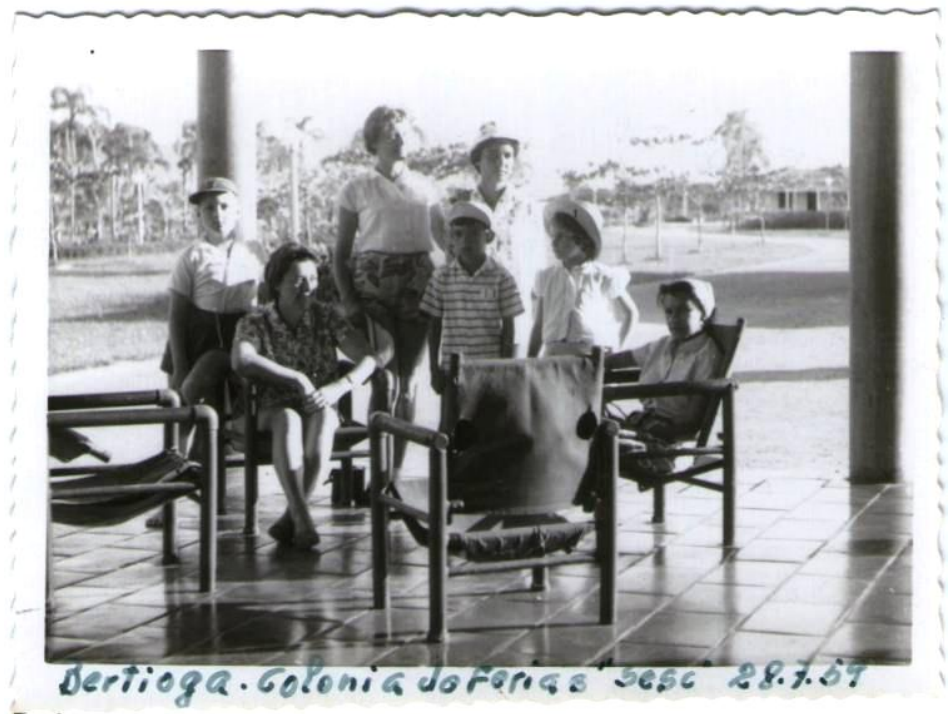

Foto 79: Cleonice sentada à esquerda acompanhada de anônimos, além de Dircinha e Dona Olga, sentada. 28-7-59. Dimensões: 9, 5 x $7 \mathrm{~cm}$.

Ao comparar as imagens da colônia na coleção CMH com a imagem publicada na Revista do Comerciáriode $1959^{91}$, é possível notar uma diferenciação entre as escolhas formais do olhar institucional e aquelas escolhas do fotógrafo amador. O primeiro revela-se na figura 8 , distante, amplo e abrangente, enquanto que as reminiscências guardadas por Cleonice mostram o lugar tal como apropriado pelo grupo. Mas nota-se uma complementaridade quanto ao local registrado em ambas as imagens. $\mathrm{O}$ espaço em que o grupo se apresenta na foto 78 é o mesmo localizado à direita entre a área construída na figura 8 , tendo ao centro o chafariz, que, visto a distância, mostra-se um tanto chapado como uma mancha branca na composição. Na foto 78 aparecem os comerciários e na figura 8 a sigla SESC escrita sobre o telhado. Nesta imagem institucional, os usuários da colônia de férias desaparecem.

\footnotetext{
${ }^{91}$ Revista do Comerciário Julho de 1959, n 32. Acervo GEDES - SESC Memórias.
} 


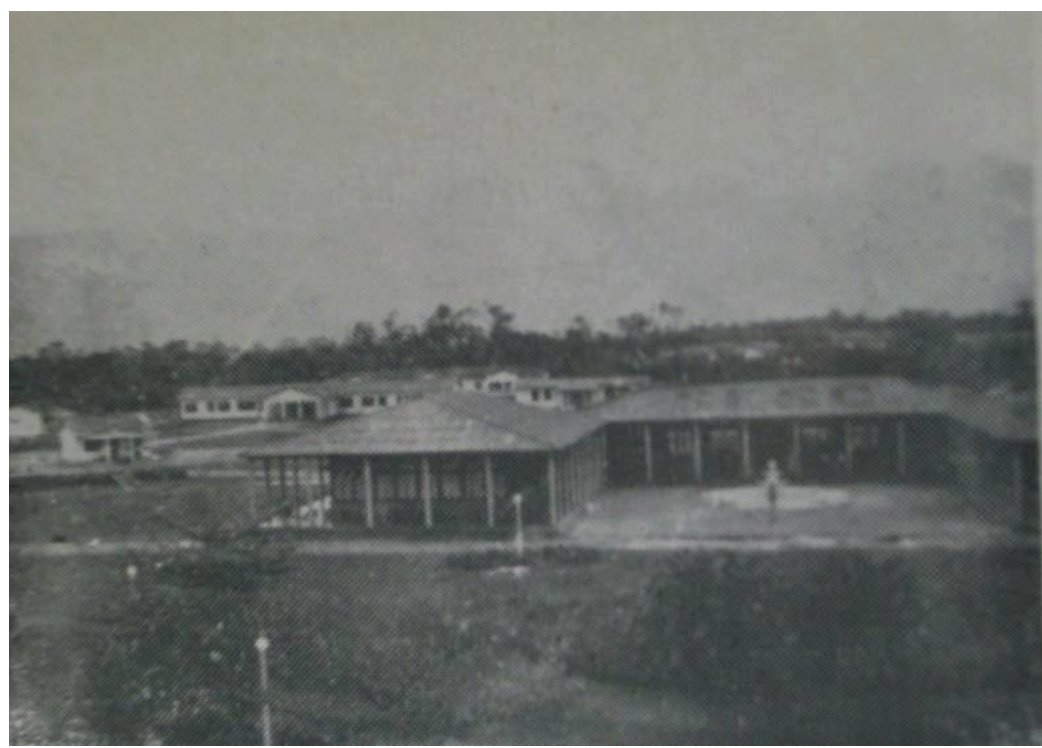

Figura 8: Fotografia da Colônia de Férias "Ruy Fonseca". Fonte: Revista do comerciário, jul. 1959, n.31 ,p.18. Acervo GEDES SESC MEMÓRIAS.

Vale a pena ressaltar que a Colônia promovia concursos de fotografia amadora, cujas categorias eram em 1956: $a$. a vida na colônia, $b$. a colônia e $c$. Bertioga pitoresca. Será que as fotos guardadas por Cleonice caberiam em algumas dessas categorias? É provável que sim, sobretudo, se considerarmos a categoria: a vida na colônia.

Após o concurso, a foto vencedora era publicada com as opiniões de “colonianos" 92 , como o Sr. Pascoal Baeta:

Na colônia de férias Ruy Fonseca encontrei as melhores acomodações, maior asseio possível, uma alimentação farta, bons educadores sociais e ambiente à altura de todos, ótimas amizades, enfim são eternas as recordações desta colônia. Viva Bertioga cheia de encanto e luz

Viva Brasil e Machado Neto criador desta maravilha. Pascoal Baeta - 1951.

Tais observações sobre a colônia, fotográficas ou textuais, ajudam a configurar a experiência social dos comerciários que ali estiveram, concomitantemente ou não a Cleonice. Trata-se de representações análogas e não menos reais que o estabelecimento construído. Da mesma forma que a imagem fotográfica, a opinião escrita dos visitantes recorta, enquadra e qualifica o espaço, as relações sociais e os serviços oferecidos aos comerciários.

\footnotetext{
92 Expressão usada pelos editores para referir-se aos frequentadores da colônia. Revista do Comerciário, Junho, 1959, n. 31, p.18.
} 


\subsection{Reminiscências em Bertioga: o passado no presente}

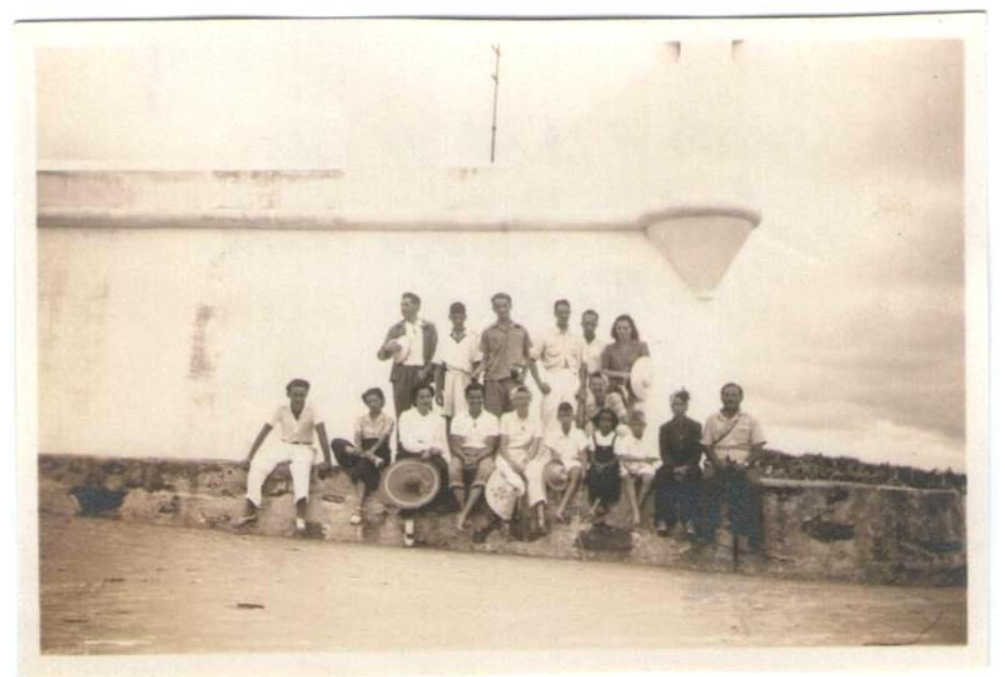

Foto 80: Cleonice e a família Souza entre várias pessoas anônimas em Bertioga, 1945. Ampliação das dimensões originais: $5,5 \times 8 \mathrm{~cm}$.

Durante o período de férias gozadas entre "11.12.44 a 18-1.45" como informa a legenda "Santos-Bertioga (dia da volta) (10-16-1-45)", o mesmo grupo fez alguns roteiros turísticos descansando, ao que tudo indica, no Hotel Lido. Entre os lugares que conheceram pode-se destacar o Forte de São João ou São Tiago (foto 80), que foi um dos vinte e quatro bens históricos tombados por Mário de Andrade em 1937, segundo Victor Hugo Mori ${ }^{93}$. Isto permite dizer que, desde então, tal construção era reconhecida como importante para a história do país; suas ruínas contavam as glórias passadas de Bertioga.

Para a análise dessas fotografias, uso a palavra monumento na acepção de sinal do passado, ligado ao sentido etimológico do termo como lembrança ou recordação. Que o Forte em questão seja um monumento nesse sentido, não há dúvidas, para ninguém, nem para o grupo de turistas que, ao posar diante dele, indica que se trata de seu maior atributo. Daí a escolha do cenário para a prática de memorização que

\footnotetext{
93 Texto completo dísponível em: http://www.vitruvius.com.br/revistas/read/arquitextos/12.136/4034
} Acesso em 29/2/2012. 
acompanha a atividade de posar e tirar e fotos. Aliás, a própria fotografia pode ser assim concebida na medida em que perpetua o passado, recordando as deambulações de Cleonice e de seu grupo. Sob esse aspecto, todas as imagens mostradas neste trabalho podem ser consideradas também como sinais do passado, como micro-monumentos.

O estado de abandono do forte, construído em 1557, vinha de muitas décadas, pois, com a projeção do Porto de Santos, esse e outros lugares começaram a perder sua importância territorial e estratégica. A situação perdura até os anos 1940, quando o Sr. Armando Lichti comprou as terras adjacentes e, reconhecendo o valor histórico daquelas construções, mandou limpar a vegetação que as cobria. Essa atitude preservacionista permitiu aos turistas visitar suas ruínas, que passaram a constituir a principal atração turística de Bertioga. Em 1943, quando o Brasil se posicionou politicamente contra os países do "eixo" (Alemanha, Itália e Japão), o Exército instalou um posto de vigilância na antiga fortaleza e suas dependências, ficando sob o comando de um oficial-tenente, que lá permaneceu até o fim da guerra, em 1945. No mesmo ano, Armando Lichti tornou a assumir a coordenação da conservação do Forte São João até seu falecimento, em $1950^{94}$.

$\mathrm{Na}$ imagem 80, o grupo de pessoas se posiciona ao centro da imagem; Cleonice porém se dilui entre eles e não estrutura a cena. A pouca importância de sua figura faz com que o forte ganhe maior relevância como motivo da foto, pois mesmo a família Velloso, que poderia fornecer estrutura à composição, se encontra à extrema direita perdida entre as figuras. Essa dispersão de personagens conhecidas mostra a importância que sua identificação tem no momento de análise das imagens em uma situação no qual o grupo fotografado é grande.

Se, nesta primeira viagem de férias, o forte (foto 80 ) destaca-se em razão da posição descentralizada de Cleonice e da família Souza, na segunda, realizada no período em que estiveram no SESC Bertioga, em 1952, é a distância do fotógrafo em relação ao tema que valoriza a construção (foto 84).

\footnotetext{
${ }^{94}$ Texto completo Disponível em: http://www.novomilenio.inf.br/bertioga/bh007.htm Acesso em 29/2/2012.
} 


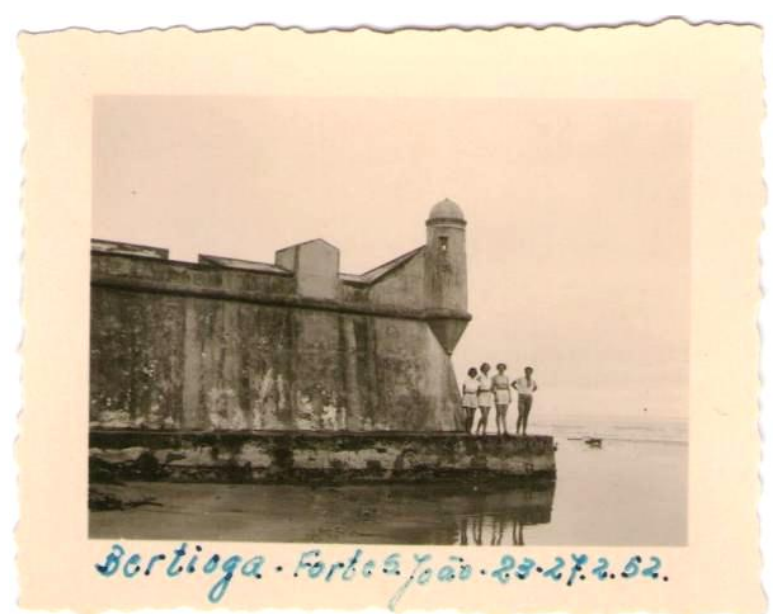

Foto 81: Dircinha à extrema esquerda, Cleonice a seu lado e anônimos no Forte São João, 1952. Dimensões: 7 x 5,5 cm.

O edifício aparece agora plenamente delineado e o grupo posiciona-se, talvez intencionalmente, distante da enorme parede da construção. A estratégia composicional define também o grupo contra a luminosidade aberta do espaço não construído, melhor visualizada no detalhe 81 a.

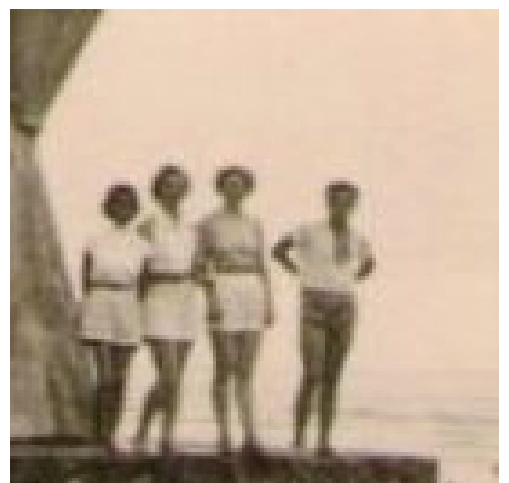

Detalhe 81a: Detalhe

Se, na viagem de 1945, cujo contexto era o fim da Segunda Guerra Mundial, os visitantes não podiam ir além da fachada (foto 81) - na segunda visita é possível notar que o turismo abriu as portas do forte. Na foto 82 , pode-se ver Cleonice, Dircinha e desconhecidos na parte superior da construção que dava para uma das torres. Não só elas figuram ali, mas também outros visitantes. 


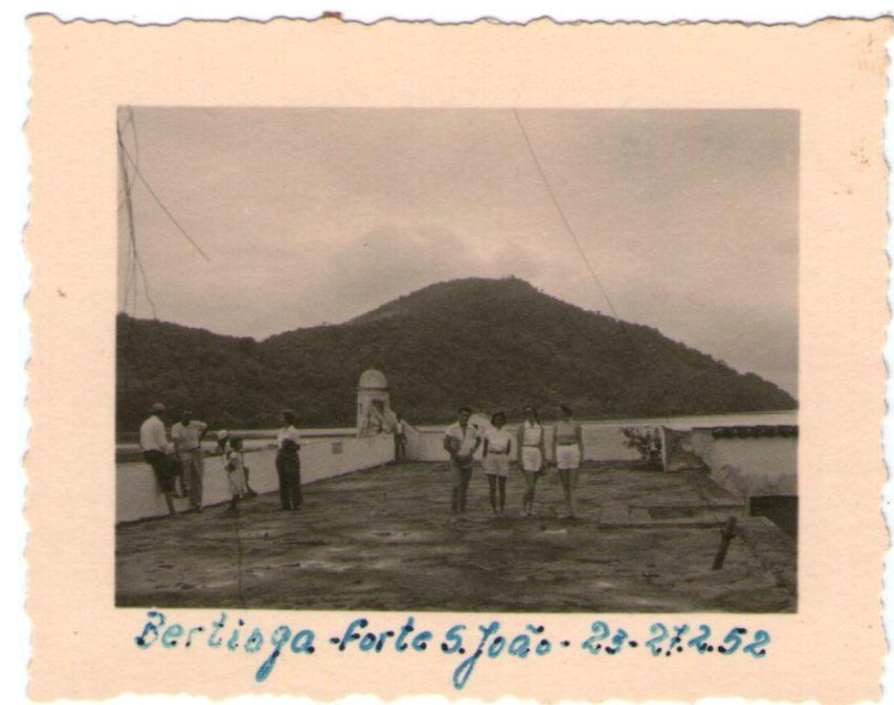

Foto 82: Da esquerda para a direita anônimo, Dircinha, Cleonice e anônima em Bertioga 1952. Ampliação das dimensões originais: 7 x 5,5 cm.

$\mathrm{Na}$ realidade, entre o tombamento do forte e as duas visitas de Cleonice, sobretudo a segunda (na qual fica evidente que o monumento pôde ser visitado), algumas mudanças de atitude em relação à importância do passado podem ser percebidas. Em 1951, foi promulgada a lei que instituía o "Dia dos Monumentos e Fontes Históricas do Município" e, um ano depois, publicado no Diário Oficial de Santos o caderno: Conheça Santos: Santos de Ontem. O caderno continha lendas, histórias, mapas da cidade, listagem e descrição de monumentos (ARAÚJO, 2008:114). Isso mostra que surgia um gosto pelo passado e seus antigos e ilustres personagens; tais fotos revelam também que um monumento como o forte já cumpria uma função relativamente turística desde os anos 1940, apesar das restrições à sua visitação.

Exemplos dessa sensibilidade diante da presença material do passado na coleção $\mathrm{CMH}$, aproximam essa construção de outras como o "Convento em ruínas" (foto 67) em Itanhaém, mas também de um outro ponto visitado em Bertioga e identificado agora como "Ruínas do convento" (foto 83).

O gosto pelas ruínas remonta ao século XVIII, momento em que o tempo passa a ser sentido como algo fugaz: "Timidamente, sem dúvida, mas com segurança, verificouse no século XVIII o afastamento da concepção de um tempo circular ou imóvel para se começar a imaginar um tempo irreversível" (CLAUDON, 1986:14-15). A criação da fotografia permitiu ao menos uma ilusão de reversão do tempo. Fundamentadas na ilusão de recuperar como reminiscência uma experiência que vai passar, essas fotos tornam o tempo relativamente imóvel. 


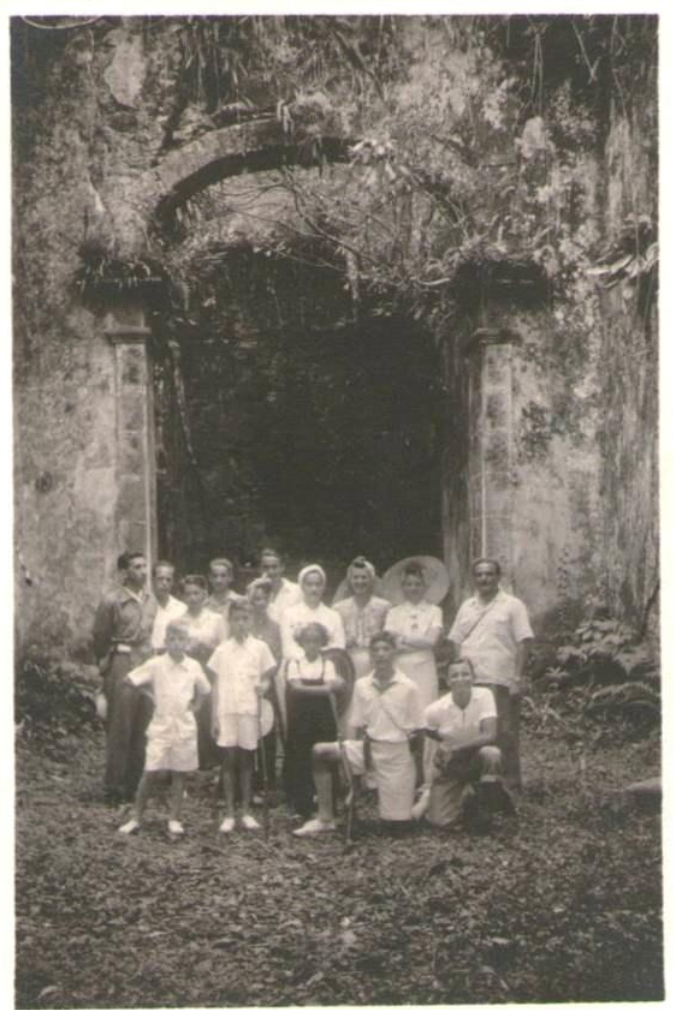

Foto 83: Férias 11.12.44-18-1-45. Santos - Bertioga - ruínas do convento (10-16-1- 45). Ampliação das dimensões originais: 5,5 x 8 cm.

$\mathrm{Na}$ foto 83, embora o grupo seja menor que aquele representado na foto 80 , não é possível identificar todos. A quantidade de roupas claras contrasta com o arco de pedra cujo interior está repleto de plantas, está na sombra. Dona Olga e Dircinha se encontram bem no centro da imagem: a primeira, com traje claro, prolonga-se na outra, com traje mais escuro. É como se Olga fosse o tronco e a pequena, suas pernas. O Sr. Souza está à extrema esquerda da foto; ao seu lado direito, uma mulher e, ao lado desta, Cleonice. A fotografia mostra-se como uma técnica e uma prática de congelamento do tempo e, nesse sentido pode ser pensada não só em seu contexto social ou econômico, mas no vínculo antropológico que mantém com a morte (BARTHES, 1984). 


\subsection{Tipos locais}

Embora, como tema na coleção $\mathrm{CMH}$, a fotografia dos moradores dos locais visitados apareça pouco, é possível constatar que essas personagens foram motivo de descrição fotográfica. Apresento algumas imagens que documentam o encontro entre visitantes e visitados. Por um lado a presença dos habitantes do lugar confirma a experiência de "ter estado ali", mas seu raro aparecimento nas fotografias colecionadas evidencia também a distancia mantida entre viajantes e moradores locais.

Essas duas categorias de atores - os de fora e os do lugar - que configuram a prática turística podem vir marcadas nas fotos por assimetrias espaciais explícitas como aquelas que organizam as práticas locais e a observação curiosa dos turistas. Na foto 84 , podem-se ver pescadores homens adultos e crianças trabalhando, grande parte deles com roupas cotidianas como camisas brancas, calças e chapéu diante da pequena audiência de turistas, especialmente visíveis ao fundo como no detalhe 84a). A situação representada é uma pesca de arrastão, em Praia Grande, nas férias de 1944-45, ação coletiva que envolvia grande esforço colaborativo entre os pescadores. O interesse despertado pela cena sublinha a distância entre a vida urbana e a vida praiana.

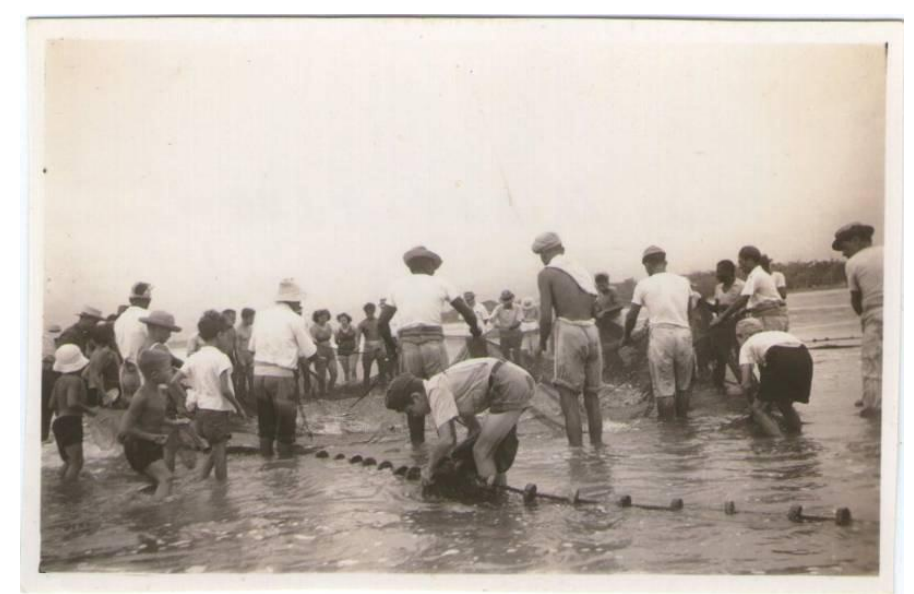

Foto 84: Pesca (legenda original) Santos - Praia Grande em 1944. Ampliação das dimensões originais: $9 \times 6 \mathrm{~cm}$. 


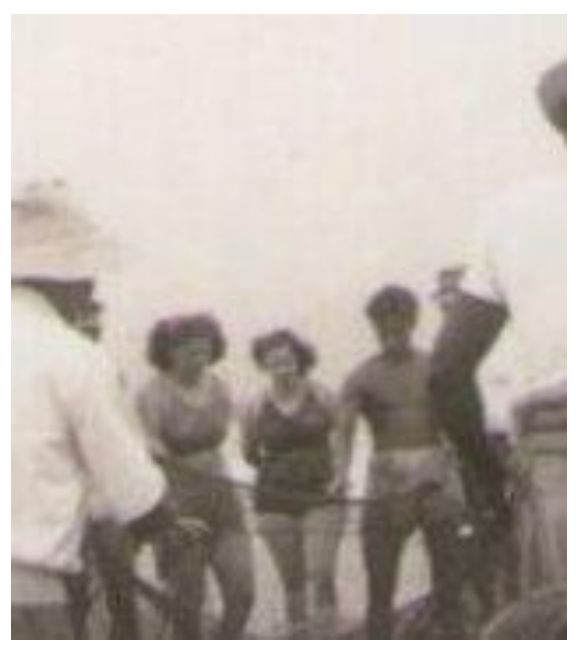

Detalhe 84a: Mulheres anônimas observam a pesca de rede.

As únicas duas mulheres aqui retratadas indicam sua condição de visitantes por seus trajes de banho. Elas observam a ação e são olhadas pelo fotógrafo. Como elas, ele se interessa pelos gestos dos pescadores em sua lida com o mar. Observe-se que as mulheres têm os braços recolhidos atrás do corpo, enquanto os homens protagonizam a cena. Tais turistas conferem à ação certo tom de exotismo. $\mathrm{O}$ fotógrafo vê a cena e clique! Ele não participa dela, apenas capta uma movimentação nas areias da praia pelo que ela tem de curioso ou típico ${ }^{95}$.

Ao distinguir os grupos, as imagens repõem a dicotomia lazer/trabalho; o turismo sendo atividade de lazer praticada por pessoas que se encontram fora de suas cidades e se valem de equipamentos e serviços, cuja prestação constitui um negócio (BARRETTO, 2004: 3). A proximidade entre visitantes e visitados, sobretudo na imagem fotográfica, oblitera o fato de que os turistas estão ali porque podem consumir tais espaços. Dessa forma o contato momentâneo que a fotografia eterniza é mediado pela possibilidade de deslocamento do turista em direção a diferentes lugares, enquanto que caiçaras e praianos permanecem em suas comunidades ${ }^{96}$.

\footnotetext{
${ }^{95}$ A imagem fotográfica dos tipos humanos regionais fez parte da cultura visual produzida no Brasil entre fins dos anos 1930-1950. A documentação fotográfica do folclore nacional teve grande importância na obra de fotógrafos como Pierre Verger e Marcel Gautherot. Ver: especificamente sobre Gautherot: (SEGALA, 2005).

${ }^{96}$ Creio ter deixado claro que as deambulações de Nelli não configuram ainda o que mais tarde será denominado de turismo de massa. São, porém, essas formas de passeios, de vivências roteirizadas, do acúmulo de fotografias, que constituirão o fenômeno turístico que se expandirá no Brasil a partir daí.
} 
Cleonice e seus parceiros de viagem não aparecem fotografados na cena de arrastão, mas eles efetivamente irão se aproximar, um ano depois, dos personagens locais, interagindo com eles e acentuando, com sua presença, os contrastes entre o rural e o urbano, o campo e a cidade, a vida tradicional e a vida moderna. Na foto 85 , essa grande proximidade demonstra o compartilhamento do espaço com diferentes propósitos, o que não ocorre sem estranheza por parte dos que vivem no local. No que parece ser uma rua de casario simples, os meninos trazem pendurado em seus ombros o resultado de uma pescaria. Na foto, os moradores ocupam o primeiro plano, pois trata-se de mostrar cenas dignas de serem registradas, aspectos de sua vida que diferem daquela que os visitantes levam na cidade grande. Cleonice está do lado esquerdo do Sr. Souza, que aponta com o dedo para a cena. Uma mulher, possivelmente a mãe das crianças cujo rosto se esconde debaixo de um chapéu de palha, segura uma cesta em uma das mãos e um pedaço de pau na outra e olha para os citadinos. Entre ela e os meninos há um signo comum, os pés descalços. Eles voltam do trabalho? Irão descansar agora? A parada pontual para foto pode ser entendida como um descanso? Almoçarão ou venderão a pesca?

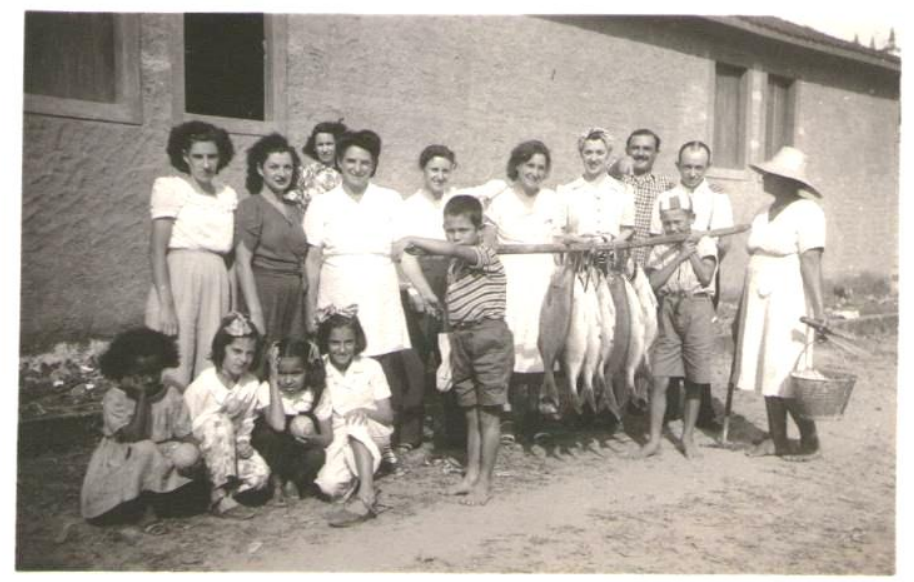

Foto 85: Cleonice e família Souza em Ubatuba - 26 a 30 de junho de 1946. Ampliação das dimensões originais: 6,5 x $9,5 \mathrm{~cm}$. 


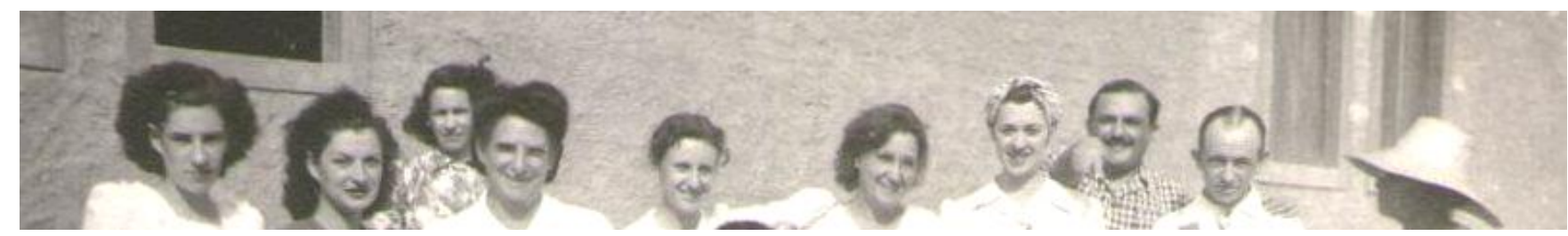

Detalhe 85a.

Turistas sorriem diante de um mundo diferente: casas, ruas de terra e seus habitantes pobres. Dona Olga de Souza está distante, atrás à esquerda, quase colada à parede como uma pessoa da terra diante da câmara (detalhe foto 85a). No primeiro plano, uma menina negra está de cócoras ao lado de três outras, entre as quais Dircinha. A família Souza figura espacialmente desagregada nesse momento: cada qual em um lugar; o Sr. Souza e Cleonice sorriem. O casal perto deles é o mesmo do passeio à Via Anchieta. As outras pessoas fotografadas mantêm alguma relação de parentesco e afinidade familial com Cleonice, talvez por parte da tia alemã Lina, sobre a qual pouco sei além do grau de parentesco e do nome informado no primeiro capítulo (fotos 3 e 7).

A foto 86 é a que melhor revela a tensão entre visitantes e visitados. Em primeiro plano, a menina negra, talvez uma agregada dos parentes de Cleonice em Ubatuba, encara o fotógrafo. Ela o faz tanto quanto Dircinha, que conhece o dono da máquina e autor de muitas fotos acumuladas por Cleonice. A coleguinha de Dircinha parece não entender a petulância da "amiguinha" nativa em sair na foto. Seus braços cruzados demonstram, talvez certa indignação, bem como seu olhar levemente inclinado sobre a outra. Cleonice e uma moça anônima olham condescendentes para a mulher que se agacha para lavar roupas. Não fica claro o que fazem: o certo é que a mulher que trabalha foi importunada, tomada de surpresa, tornando-se o assunto de retrato. Trata-se de uma cena dinâmica, provavelmente em razão das diferenças sociais que reuniram as pessoas na foto. O espaço reproduz essas assimetrias entre os componentes da cena. A sociedade que aparece na foto, que está recebendo os turistas, é pobre e isso acentua a desigualdade no relacionamento entre visitantes e visitados. 


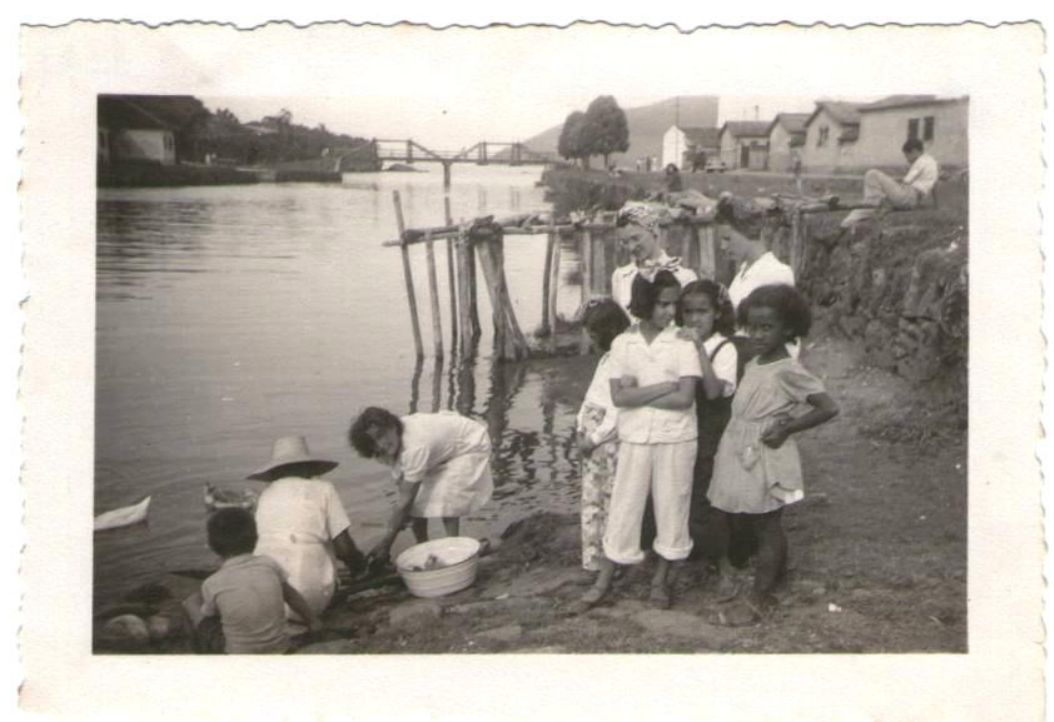

Foto 86: Cleonice (de turbante mais claro), mulher anônima, Dircinha (de vestido escuro com alças), criança anônima e caiçaras em Ubatuba - 26 a 30 de junho de 1946. Ampliação das dimensões originais: 6,5 x 9,5 cm.

Ao recortarmos a imagem, aproximando algumas das figuras aí presentes, podem-se notar as diferentes expressões faciais resultantes do contato entre pessoas estranhas. No detalhe 86a, Cleonice sorri complacente, enquanto que a mulher anônima ao seu lado tem expressão séria. A menina da cidade (detalhe 86b) olha estranhando a presença daquela do local, que encara a câmara. No detalhe $86 \mathrm{~b}$, vê-se que a mulher que lava a roupa parece surpresa, talvez por não entender qual a utilidade de uma foto como essa.

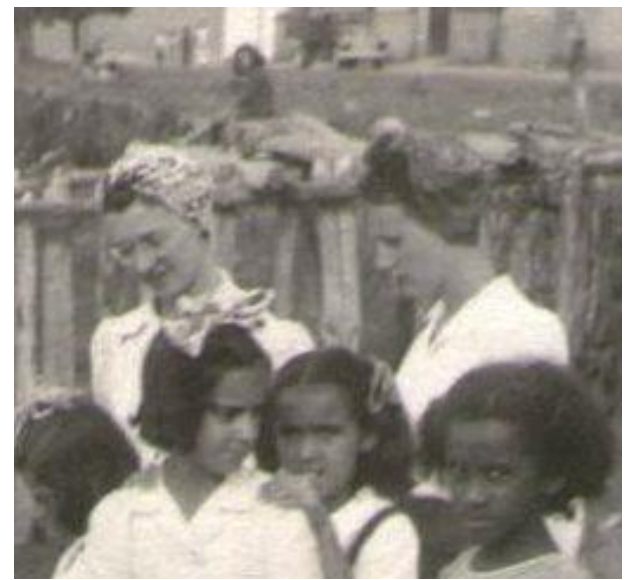

Detalhe 86a:

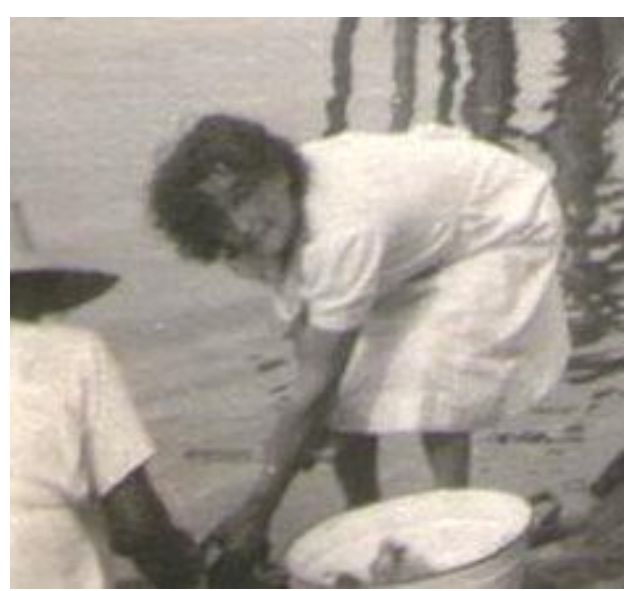

Detalhe 86b: Detalhe. 
No contato do turista com os habitantes do lugar torna-se possível distinguir um sistema de oposições cujos termos básicos são a proximidade e a distância entre o viajantes e residentes.

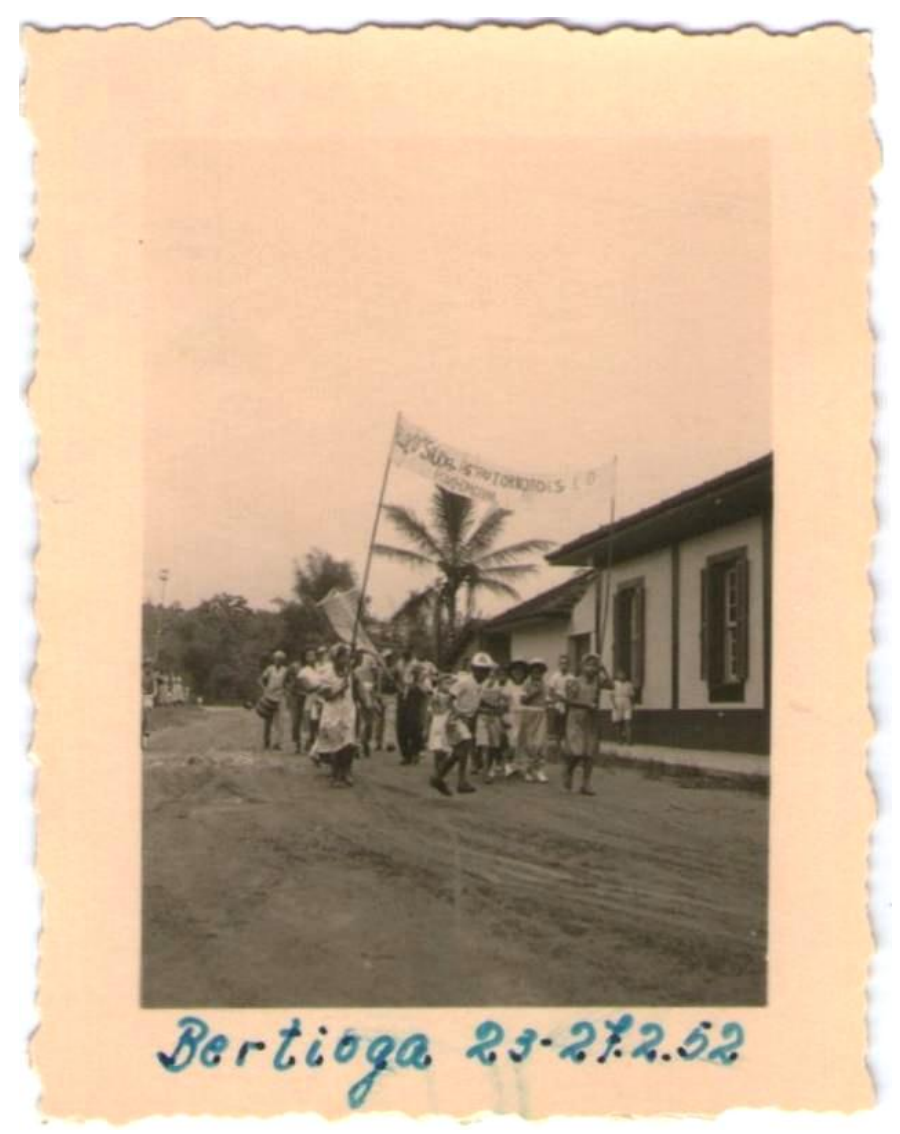

Foto 87: Manifestação de rua em Bertioga, 1952. Ampliação das dimensões originais: 7 x $5,5 \mathrm{~cm}$.

Na segunda viagem que fizeram em 1952 à Colônia de Férias do SESC o grupo saiu para conhecer o entorno. Aqui mantém-se a mesma distância e, como na foto 84, a imagem 87 mostra uma movimentação de populares, porém agora predominam crianças e o momento não é de trabalho, mas de festa. A legenda nada informa sobre o tema da foto, mas a identificação "Bertioga" revela aspectos da antiga vila como o casario à esquerda. Nota-se que o grupo é formado por crianças e que sua presença na rua pode ter relação com as celebrações do carnaval. Os escritos em uma faixa que se eleva sobre as casas sugere algo como: "Sauda as autoridades"(detalhe $87 \mathrm{a}$ ). O olhar turístico do fotógrafo vai caçando motivos e temas exóticos, pitorescos ou inusitados que completem a sua experiência de viagem. 


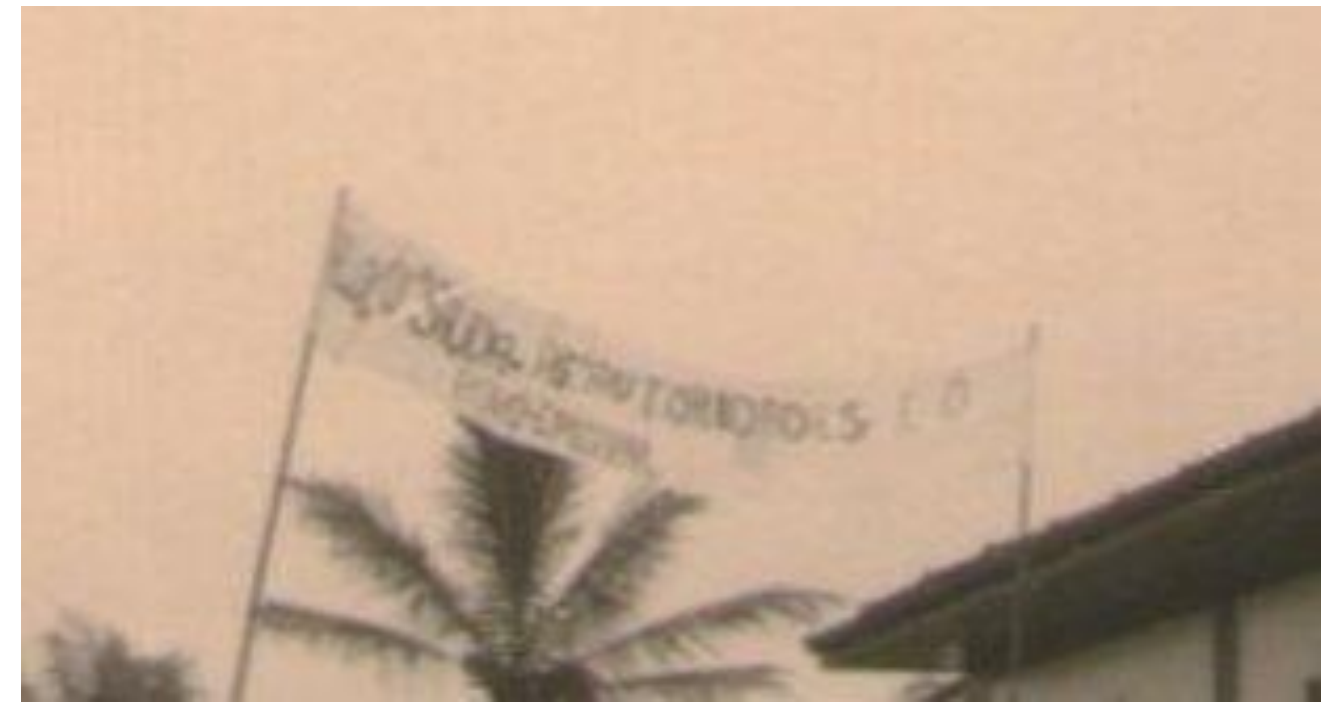

Detalhe 87a: Faixa.

\subsection{Entre o porto e a praia: duas imagens e um sentimento}

O ambiente litorâneo aparece como um destino visualmente diversificado na coleção CMH, cujos temas vão além das areias da praia. Cleonice guardou seis imagens, duas das quais mostro a seguir. Elas são a síntese da dupla função da cidade de Santos: o Porto, que, como diz Richard Morse, é o seu principal "escoadouro para o mundo", e a praia, cujas fotografias exibidas neste capítulo são um testemunho do prestígio que a cidade tinha para Cleonice e para as pessoas em geral (MORSE, 1954:292 nota 537). 


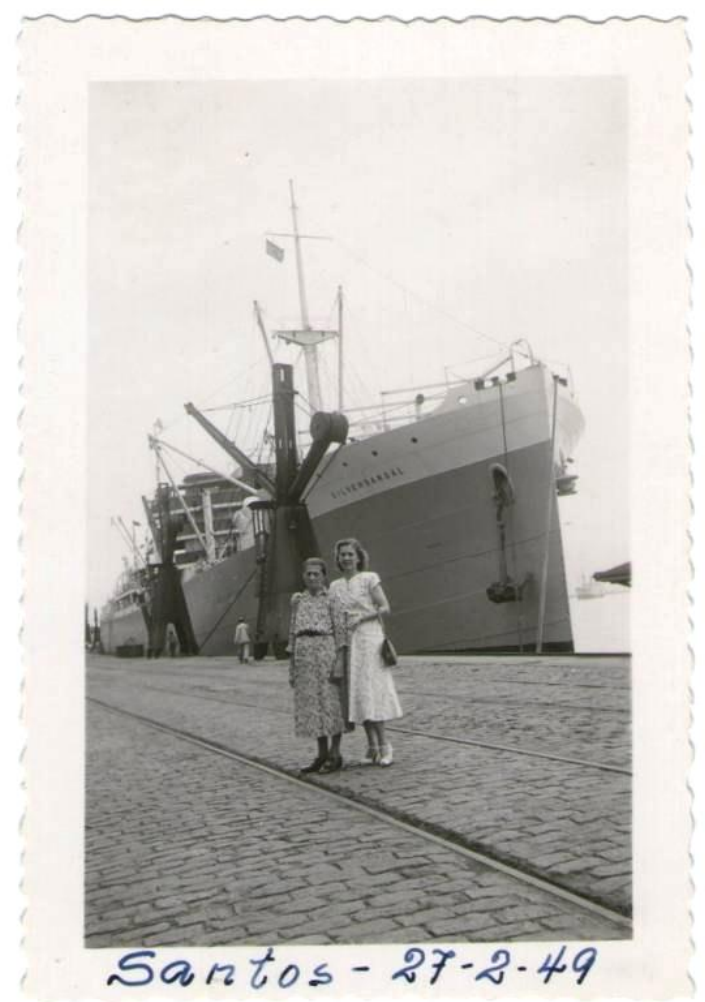

Foto 88: Cleonice e sua mãe no Porto de Santos, tendo ao fundo a embarcação Silversandal, em 1949. Dimensões: 6,5 x $10 \mathrm{~cm}$.

A foto 88 mostra o porto por meio de uma estratégia do fotógrafo de verticalizar a tomada. Ao fazer isso, ele opõe a função desse cenário à praia quando escolhe para esta a tomada horizontal na imagem seguinte (foto 89). Observe-se que as modelos estão de pé, paralelas à linha frontal da enorme embarcação atrás, símbolo da modernidade que aproximava São Paulo do mundo. É Richard Morse quem lembra ainda que esse porto "tem estado, desde 1925, cronicamente congestionado; os navios às vezes ficam atracados durante meses e os exportadores estrangeiros aumentam os fretes das mercadorias para aí destinadas" (idem). E completa: "Atualmente estão em andamento planos para drenagem e expansão das docas" (ibidem, 292, nota 537). Esse dado é fornecido pelo autor em 1947, dois anos antes da foto feita, precisamente no ano em que a economia brasileira voltou a crescer $^{97}$.

Na década de 1930, como sabemos, as viagens transatlânticas se faziam por via marítima e o porto de Santos era uma das portas de entrada e saída do país. Cleonice

\footnotetext{
${ }^{97}$ “O aumento dos preços do café nos mercados internacionais, a partir de meados de 1949, causou melhoria geral na economia brasileira. Durante os seis primeiros meses de 1950, as exportações desse produto renderam à Nação 5,5 bilhões de cruzeiros contra 4,2 bilhões no mesmo período em 1949, e isto apesar da redução do volume, que caiu de 8,1 milhões de sacas em 1949 para 5,6 milhões em 1950". Texto completo disponível em: http://www.novomilenio.inf.br/rossini/sts1950.htm Acesso em 2/3/2012.
} 
não está chegando nem está se despedindo. Ao escolher retratar-se ao lado desta obra de engenharia não é impossível que esteja orgulhosa do espaço, a foto funcionando como um reconhecimento do porto, que talvez tenha permitido que ela chegasse a São Paulo ainda nos anos 1920. Pelo porto chegaram provavelmente muitos dos produtos do setor químico no qual ela trabalhava, produtos que vinham da Alemanha de modo regular, até à retaliação referente às exportações de produtos químicos daquele país no contexto da Segunda Guerra.

É, porém, a praia, como indicado ao longo do capítulo, que predomina como motivo em sua coleção. Isso ocorre porque a função balneária ou de veraneio tornou-se mais representativa em Santos no decorrer dos anos 1940 acompanhando o aumento de turistas, seja em razão do crescimento de alojamentos para recebê-los, seja da construção de prédios para segunda residência, como visto anteriormente. Ademais a diversão balneária não era atributo do porto.

A foto 89 se opõe à 88 pelo formato fotográfico e pelos elementos que compõem a cena. A escolha da praia como motivo encontra-se aí reafirmada, especialmente a visão do mar que oferece uma continuidade horizontal entre o planalto e o litoral, abstraindo simbolicamente o relevo da Serra do Mar. Se, na foto 88, as modelos estão sérias, em posição ereta - gravidade enfatizada pela imponência do navio que confere um ar monumental à imagem -, na segunda, essa seriedade é quebrada por três elementos: as areias da orla marinha, o fundo horizontal de montanhas e a roupa de banho de Cleonice. Além disso, o banquinho e a movimentação dos banhistas dão ao cenário uma vida que inexiste na foto do porto. Isso tem a ver com a posição do fotógrafo no momento de produção do registro. Em cada espaço, a movimentação e circulação de pessoas difere, bem como as regras de comportamento corporal captadas pela fotografia, gerando performances fotográficas distintas

Observemos ainda que a mãe de Cleonice usa a mesma roupa nas duas imagens, ao passo que Cleonice, que completaria 30 anos de idade em maio daquele ano, mudou seu traje assumindo, no segundo clichê, um papel inquestionável de banhista. Estas duas fotografias são parte de uma série de seis imagens, as únicas em que Dona Ida aparece na praia. A mãe de Cleonice não chegará a conhecer a segunda residência da família Velloso, pois morrerá três anos antes dessa aquisição. Sua filha, ao contrário, tornará o litoral um destino turístico cada vez mais presente em sua vida. 


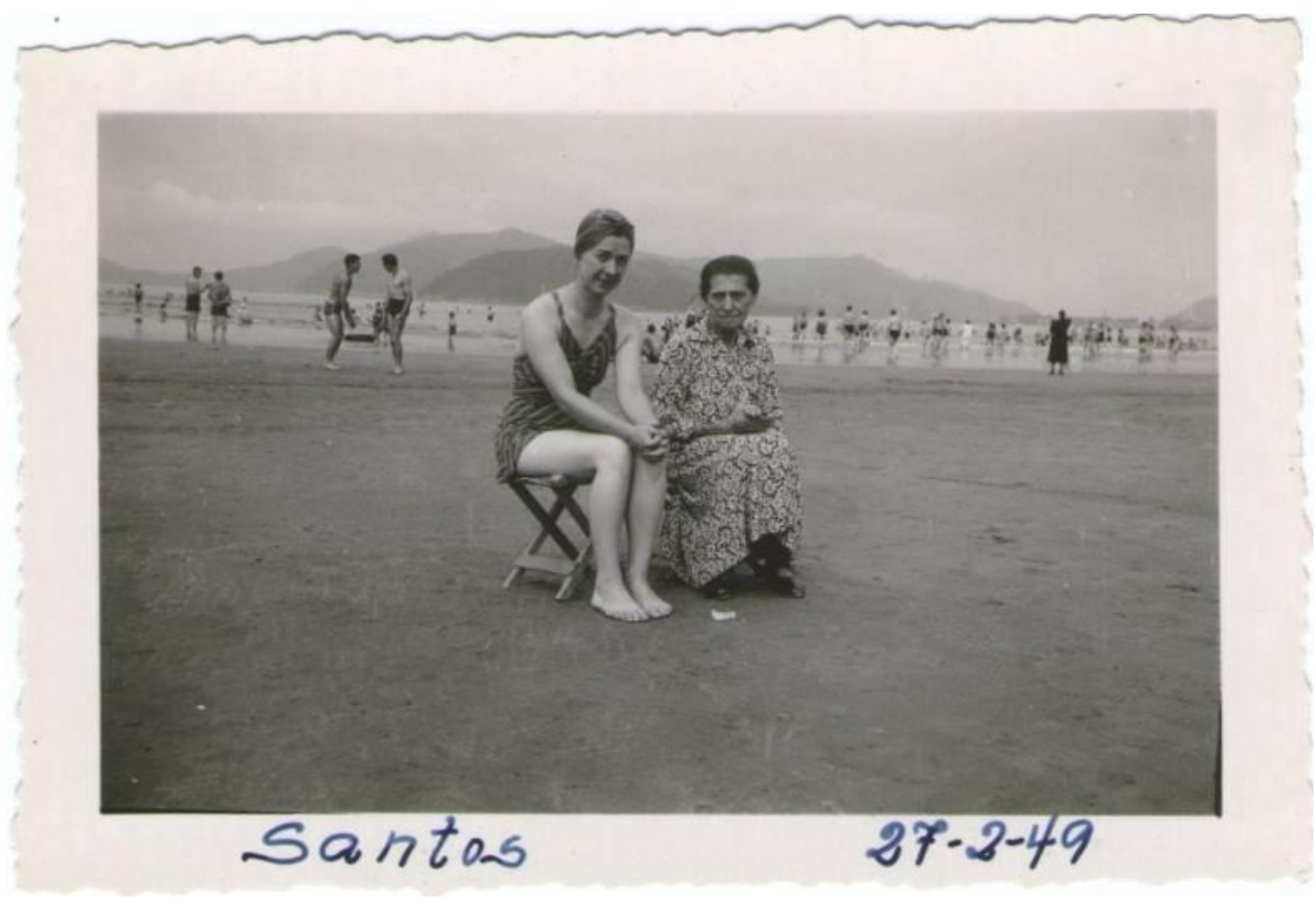

Foto 89: Cleonice e sua mãe em Praia de Santos em 1949. Ampliação das dimensões originais: 6, 5 $\mathbf{x} 10 \mathrm{~cm}$. 


\subsection{A segunda residência na praia}

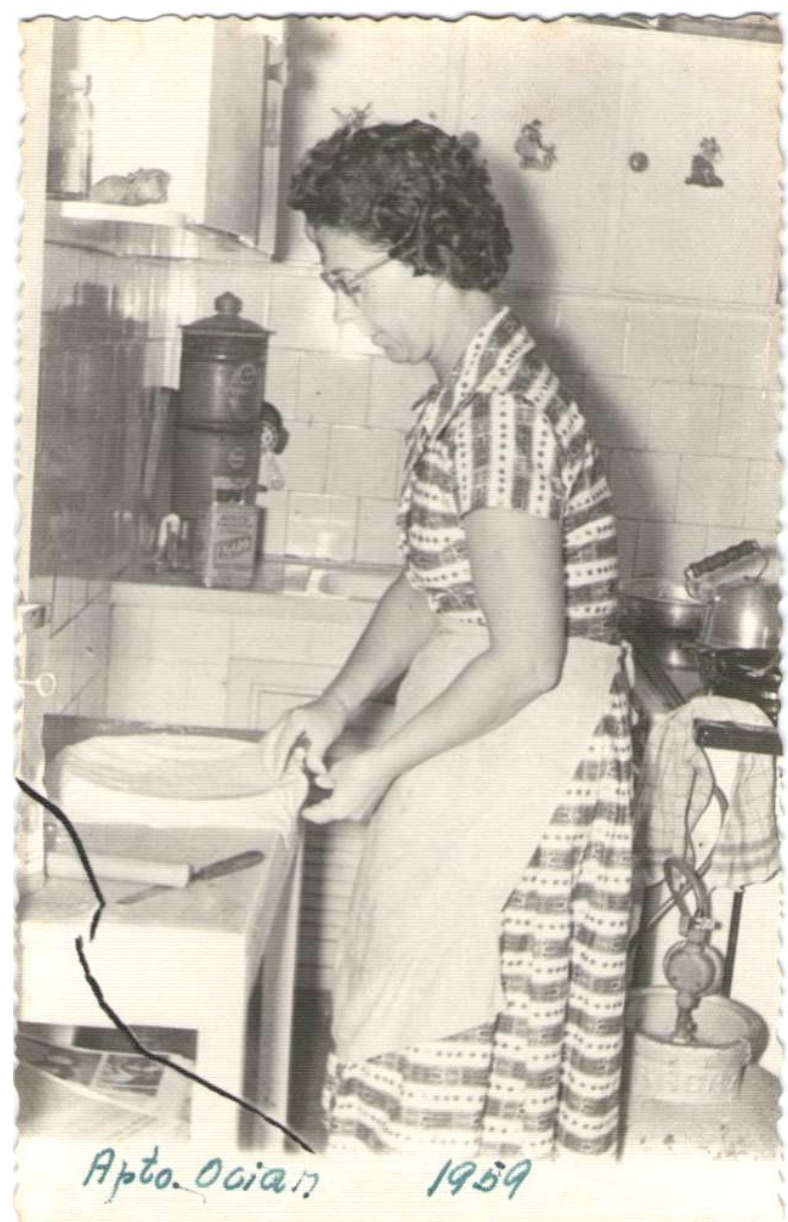

Foto 90: Cleonice no apartamento em Cidade Ocian, Praia Grande em 1959. Dimensões: 8,5 x $13,5 \mathrm{~cm}$.

Cleonice está no apartamento em Cidade Ocian, bairro de Praia Grande, que esteve ligado a São Vicente até 1967 (foto 90). Esta imagem, feita dois anos depois da compra do apartamento em 1957, revela diferenças fundamentais entre estar na praia alojado em pensão ou hotel ou frequentá-la como convidada em uma segunda residência. A primeira diferença diz respeito ao próprio registro fotográfico, que a retrata em um espaço incomum da casa. Ela mostra-se aí como alguém da casa, pois figura na cozinha, zona frequentada normalmente pelos de dentro. Os atributos femininos são destacados, ela aparece fazendo comida, como mais tarde, no mesmo apartamento, irá aparecer fazendo tricô. O litoral enquanto lugar de passeio, ligado ao 
sol e ao mar, reduz-se na imagem a uma área molhada da casa e, não fosse a identificação em caneta azul, seria impossível saber que ela está mesmo no empreendimento imobiliário que criou o bairro Cidade Ocian.

O nome OCIAN é a sigla que identifica, desde 1946, a Organização Construtora e Incorporadora Andraus Ltda ${ }^{98}$. Essa empresa estava sediada na capital paulista na Avenida Ipiranga 795, nas imediações do local de trabalho de Cleonice. A empresa de Roberto Andraus erigiu no litoral 22 prédios e 1.350 apartamentos. Tal empreendimento foi considerado à época um dos projetos mais modernos do litoral que reunia uma infraestrutura de água, luz, esgoto, sistema próprio de tratamento de esgoto, telefone etc. (VIEIRA, 2008).

O fenômeno das residências secundárias no litoral paulista, cujo objetivo era atender a uma demanda associada ao lazer, que, naquele contexto, aparece como o contraponto ao trabalho, remonta, como já visto, ao início do século XX. Essas propriedades privadas, inicialmente voltadas para as camadas mais ricas da população, surgem na forma de chácaras ${ }^{99}$ ou de palacetes situados na orla da praia. Os primeiros veranistas privilegiados que tinham condições financeiras as adquiriam. Aqueles que não dispunham de amplos recursos continuavam a depender de hotéis modestos, de pensões e de serviços de aluguel de armários e roupas de banho para frequentar a praia. Seguindo uma tendência iniciada na capital, nos anos 1940 surge a verticalização em vários pontos de Santos como a praia José Menino. Tão logo o fenômeno começa a estabelecer-se na capital, inicia-se paralelamente em Santos transformando estrutural e materialmente o espaço da praia. A proximidade e o transporte fluvial entre algumas localidades e Santos valorizava certas praias. Para se chegar até Praia Grande, por exemplo, era necessário passar por Santos, trajeto obrigatório até o início dos anos 1960. A relativa proximidade da capital estimulou a criação de novos lugares a preços mais acessíveis a uma camada média em expansão que começava a acumular condições de financiar um segundo imóvel. Lembremos que o Sr. Souza Filho, proprietário do apartamento na Cidade Ocian que Cleonice frequentou, fundou com outros sócios a Sociedade Química Brasileira, em 1945 e, portanto, quando da aquisição deste

\footnotetext{
${ }^{98}$ Fundada de acordo com informações obtidas no site da Jucesp em 7/5/1946. Ainda hoje atua na área de: "serviços de locação, arrendamento e intermediação de bens imóveis (corretagem)". Disponível em: http://www.jucesp.fazenda.sp.gov.br/Acesso em 23/4/2012.

99 Como a do pintor Benedito Calixto de Jesus (op.cit) que ficava em São Vicente como atestam documentos fotográficos conservados no acervo do Museu Paulista da USP. Ver: IC. 1.03445-0000-0000 São Vicente. Data: 14/10/1924 e também IC. 1-03439-0000-0000. Acervo textual e Iconográfico do Museu Paulista da Universidade de São Paulo.
} 
apartamento a empresa já possuía uma experiência de doze anos de atuação, fator que, nos anos 1950, foi importante, pois o ramo em que atuava vinha tendo crescimento expressivo (INOUE, 2011).

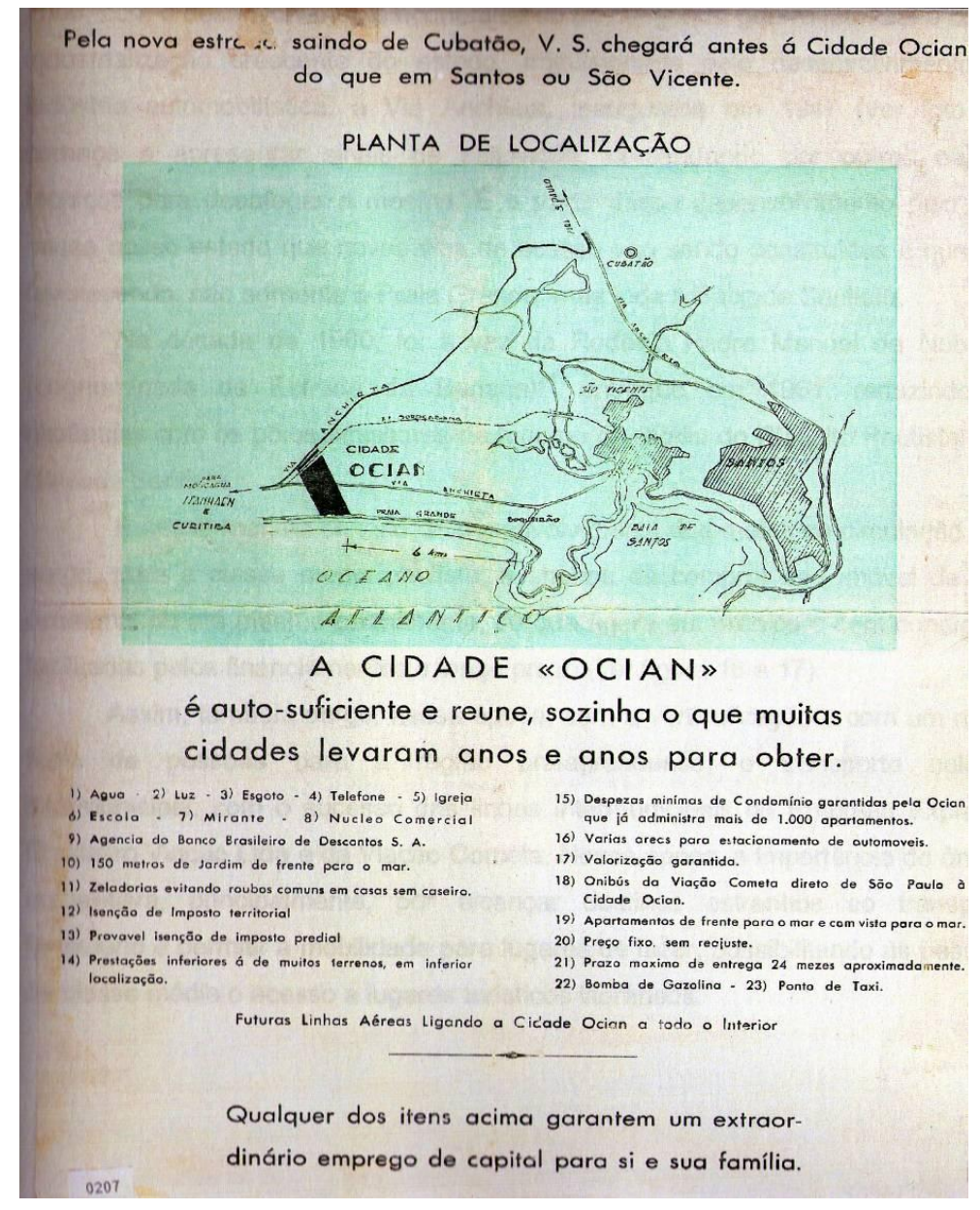

Figura 9: Propaganda do Conjunto Habitacional Cidade Ocian. Fonte: Imário Vieira 2008: 127.

Um fator decisivo para a compra desse novo imóvel foi a facilidade do acesso viário ao planalto. A propaganda com a planta de localização do empreendimento Cidade Ocian, figura 9, fornece dados importantes, indicativos do motivo por que este condomínio atraiu tantos compradores. A primeira frase escrita bem no alto do panfleto diz: "Pela nova estrada saindo de Cubatão, V. S. chegará antes á (sic) Cidade Ocian do que em Santos ou São Vicente". Essa facilidade de acesso pode ter sido um dos atrativos de compradores que, já possuindo a residência que "responde a mais elementar necessidade de habitar, morar, de ter abrigo", buscava uma segunda, cuja melhor definição é que esta não se configura como suporte da vida cotidiana (SEABRA, op.cit: 4), ou ao menos não antes da aposentadoria. Como assegura Olga Tulik "residências 
secundárias podem se transformar em residências permanentes, em virtude da fixação de antigos turistas, que ao se aposentarem, transferem para o destino de fim de semana o seu domicílio principal” (TULIK, 1996: 64). Não é possível afirmar que a família Souza tenha feito isso; no entanto, é interessante ressaltar como a segunda residência, tal como as fotos a qualificam, rotinizam o destino litorâneo.

É importante sublinhar a repercussão dos empreendimentos imobiliários construídos na praia ${ }^{100}$ que transformam a vida urbana das camadas médias. As imagens traduzem diferentes aspectos desse processo, tais como: a conquista de um lugar fixo para a realização de refeições; para o repouso e para novas formas de interação social; a mobilidade social representada agora pela capacidade de compra do consumidor e pela novidade do empreendimento imobiliário, que altera a paisagem natural e humana. O feixe de aspectos que redefinem o espaço litorâneo de Praia Grande revela a importância da mobilidade social experimentada pelos Souza como proprietários e por Cleonice, como amiga da família. Esses aspectos redefinem também o registro dos passeios: se nas viagens anteriores as tomadas não ultrapassavam em geral as fachadas ou aspectos exteriores da área social dos hotéis e pensões (como demonstram as fotos $55,59,61,66,68,69,70$ e 71), as fotografias da segunda residência invadem espaços inéditos, como a cozinha (foto 93). Mas continuam ausentes, como de resto acontece com muitas fotografias de família, os quartos de dormir e os banheiros; isto é, os espaços de uma privacidade moral e sexual alheia a fotogenia.

\footnotetext{
${ }^{100}$ Para uma análise dos impactos negativos da ocupação ver: (TULIK 1996: 63-72).
} 


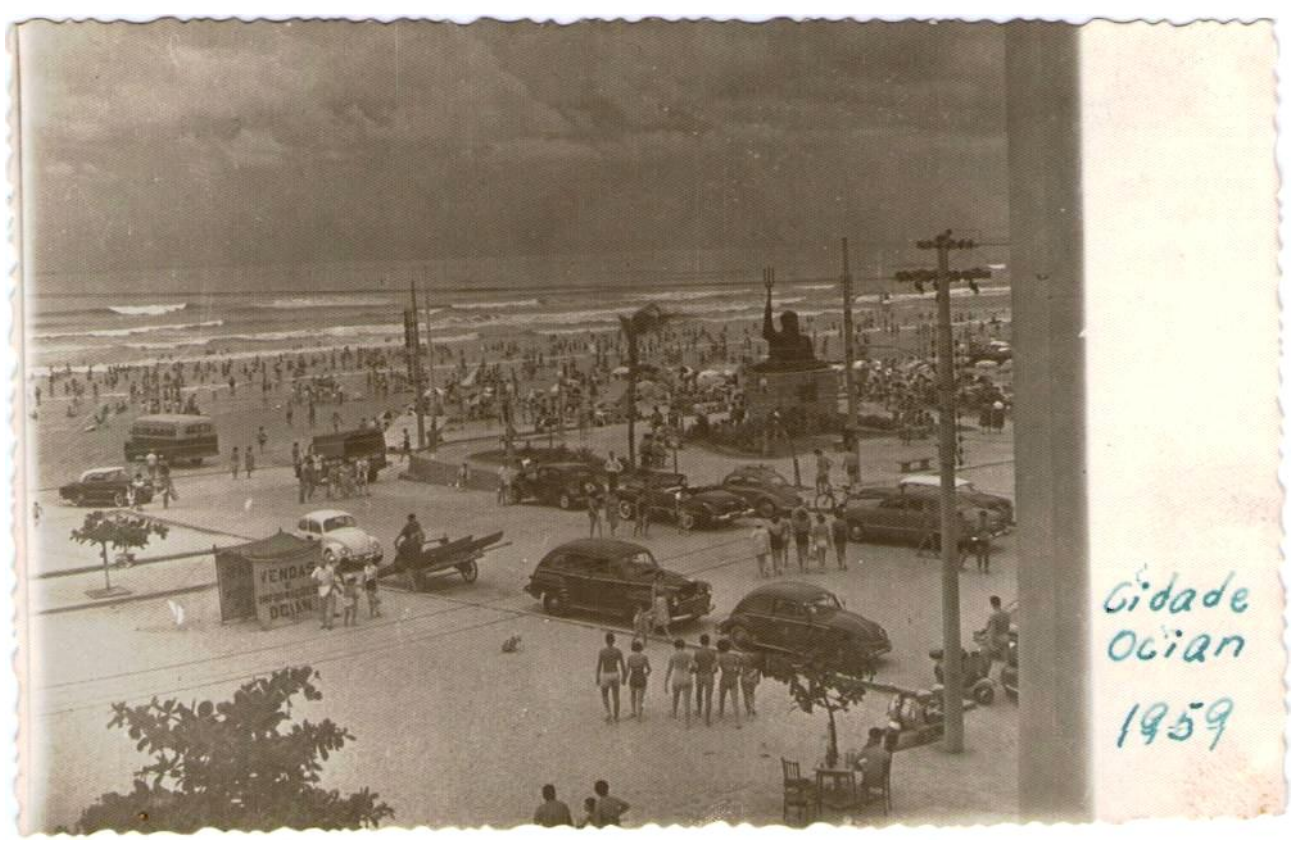

Foto 94: A orla da praia de Cidade Ocian vista possivelmente do apartamento de propriedade do Sr. Souza Filho em 1959. Ampliação das dimensões originais: 8,5 x 11,0 cm.

A experiência de estar na praia se modifica também à medida que o fotógrafo amador pode visualizar o movimento fora da residência confortável. Possuir um apartamento de frente para a orla possibilitava ao proprietário ter o mar como horizonte, podendo distanciar-se dos veranistas na orla, como mostra a foto 94. A tomada feita de cima e à razoável distância mostra uma intensa movimentação de pessoas. Na imagem acima aparecem vários automóveis estacionados, o que indica ser este veículo de transporte uma das modalidades mais importantes de deslocamento para o litoral, a partir dos anos 1950. A imagem inclui, à direita, uma faixa vertical em cinza e branco. Trata-se da parede da varanda do apartamento de onde o fotógrafo faz o registro, portanto, do limite entre a casa e a rua. Observando-se mais de perto alguns detalhes, pode-se notar (detalhe 94a), que há uma barraquinha muito simples onde se pode ler: "Vendas e informações Ocian”. Ora, é possível que este precário posto de vendas seja justamente o local de venda dos imóveis que (figura 9) a propaganda informa serem de investimento de "Valorização garantida". 

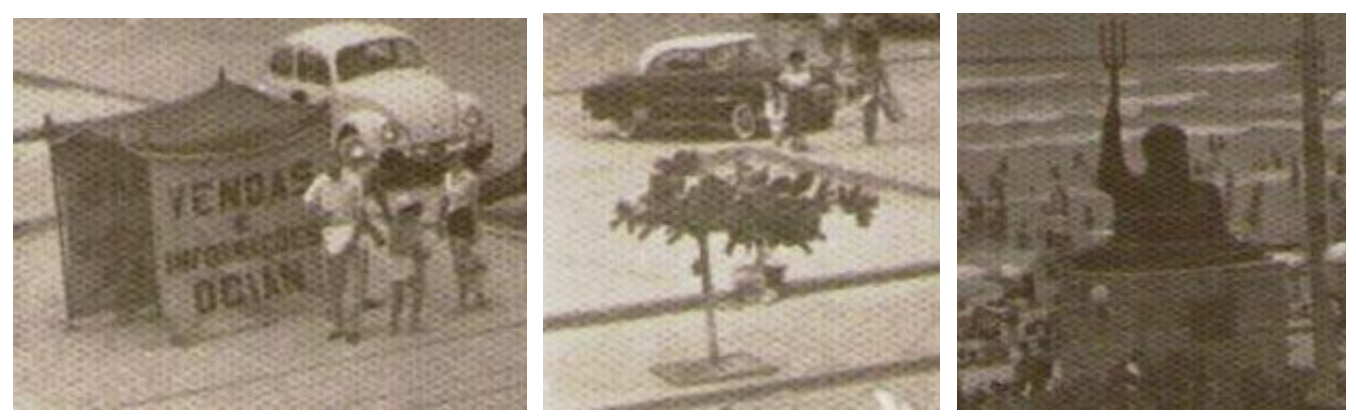

Detalhes 94a, 94b e 94c: Posto de vendas e informações sobre apartamentos, carros, jardins e monumento ao deus Netuno em Cidade Ocian, Praia Grande, Santos, 1959.

$\mathrm{Na}$ imagem seguinte, 94b, nota-se o paisagismo recente da orla pela altura das árvores, então muito novas, que provavelmente deviam compor os " 150 metros de jardim de frente para o mar" informados na figura 9. Na imagem 94c, por sua vez, destaca-se o monumento que nasceu com a Cidade Ocian: uma figura em bronze do deus Netuno, em cuja base há uma placa com a data de fundação e os nomes dos agentes que erigiram o bairro.

É possível que o fotógrafo tenha captado a cena da foto 94 da varanda do Edifício São Jorge (foto 95). Nesta imagem, estão: Cleonice na extremidade direita ao lado de Dircinha, uma senhora anônima, provavelmente parente de alguém, pois ela aparece outras vezes, Olga de Souza e o filho (ficam sem identificação nesta cena as outras pessoas). Esse registro, tomado de baixo para cima, foi possível, considerando-se que o Sr. Souza utilizou uma câmara portátil comum, porque o edifício tinha apenas quatro andares. Fato que a fotografia, por sua própria natureza seletiva abstrai, impossibilitando saber com exatidão se o apartamento ficava no segundo ou terceiro andar. 


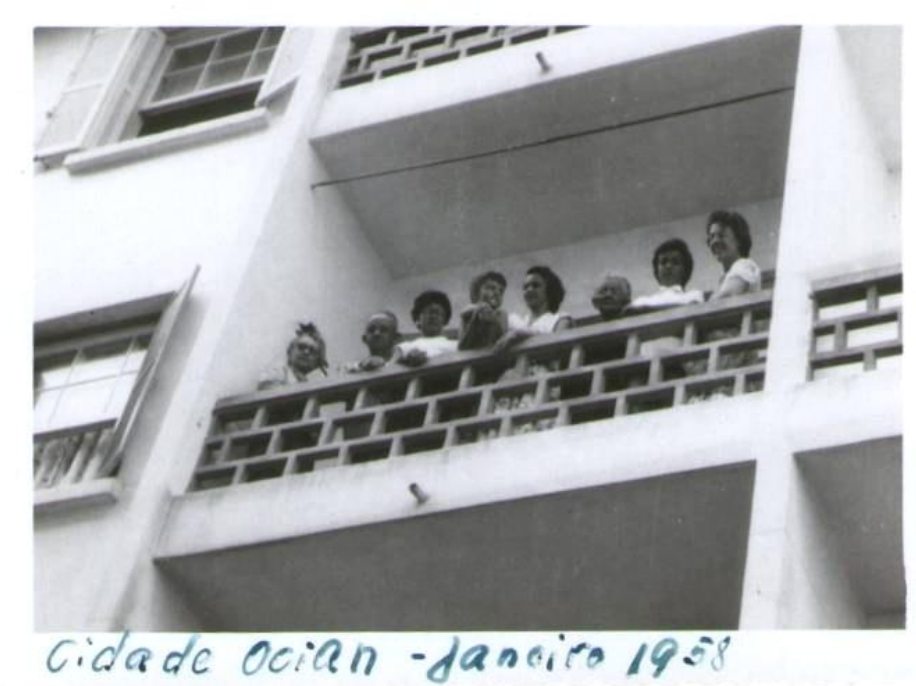

Foto 95: Cleonice , a família Souza e anônimos na varanda do apartamento em Cidade Ocian, 1958. Dimensões: $6,5 \times 9 \mathrm{~cm}$.

Embora a residência secundária não seja suporte da experiência cotidiana, como é o caso da primária, ela permite que a fotografia feita a partir dela apanhe representações da família, do mundo doméstico e da praia como cenário da sociabilidade familiar e como extensão da casa. Ao percorrer o apartamento, tarefa que fiz começando pelo retrato na cozinha, é possível observar algo da dinâmica das interações no interior da casa como mostra a foto 96 (tomada no dia 21/7/60). Pela imagem, vê-se como as mulheres compuseram algumas horas de ócio e recreação nas férias daquele ano iniciadas no dia 16. Da esquerda para a direita: Olga de Souza com o novelo de lã que lhe cobriu o rosto; Dircinha à sua direita, que se casará em meados da primeira metade dessa década; Cleonice, solteira como Dircinha, mas tornada igual, no plano fotográfico às casadas - Olga e Laura, sua cunhada. Novamente, a extração dessa foto da rede de relações que ela mantém com todas as outras imagens e, especialmente, com as séries relativas ao litoral, pode levar ao engano quanto à condição civil de Cleonice. Tal efeito advém dos afazeres manuais cotidianos como cozinhar (foto 93) e tricotar (foto 96), atividades ensinadas nas escolas femininas à mulher que queria casarse ou que era casada entre 1920 e $1960^{101}$. A foto abaixo mostra um instante da

\footnotetext{
${ }^{101}$ O Anuário das Senhoras possuía uma sessão chamada "Hora do lazer" na qual os editores orientavam as mulheres a utilizar esse momento bordando toalhas, guardanapos, lenços ou peças para a "gente miúda" como casaquinhos de bebê. Ver: Anuário das Senhoras, Ano XVI, 1949, p.p.78, 79, 96, 145,176$180,186,192$.
} 
sociabilidade feminina no conforto da residência secundária, durante uma temporada de férias.

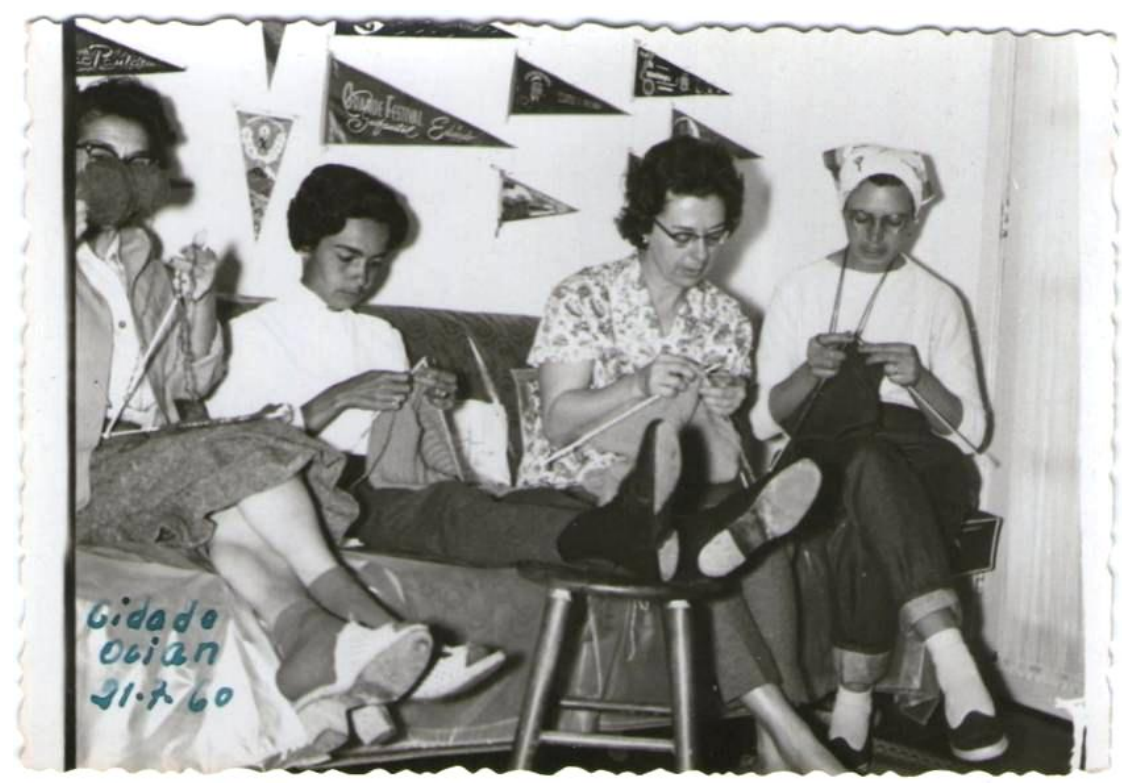

Foto 96: Da esquerda para a direita Olga, Dircinha, Cleonice e Laura tricotam no apartamento de Cidade Ocian em 1960. Ampliação das dimensões originais: $7 \times 10 \mathrm{~cm}$.

Mais uma vez, ela enfatiza como, é só com a compra da segunda residência que o interior do alojamento turístico é efetivamente visualizado: cozinha, varanda, sala e sala de jantar (foto 97). No ambiente específico da sala de jantar vemos uma celebração importante: inauguração do apartamento no dia 1-11-57 (legenda original). A sala é claramente dividida por uma fita e, segurando-a, estão igualmente o anônimo filho pequeno do casal Souza e Claudio, sobrinho de Cleonice. No centro, Olga de Souza e a seu lado Dircinha, uma mulher anônima e, bem ao fundo, Germano e Laura. O Sr. Souza está em primeiro plano e tal foto parece ser o resultado da programação automática da câmara amadora. O tom celebrativo é ressaltado por alguns elementos postos à mesa como um bolo, duas garrafas de bebida e taças (detalhe 97a). A imagem tem exatamente 9 centímetros, no qual o grupo espremido entre o batente da porta ocupa apenas 2 centímetros, enquanto que o Sr. Souza com seus braços abertos e barriga saliente ocupa quase 3 centímetros afirmando uma desigualdade espacial tornada momentaneamente um marcador de diferença entre eles. 


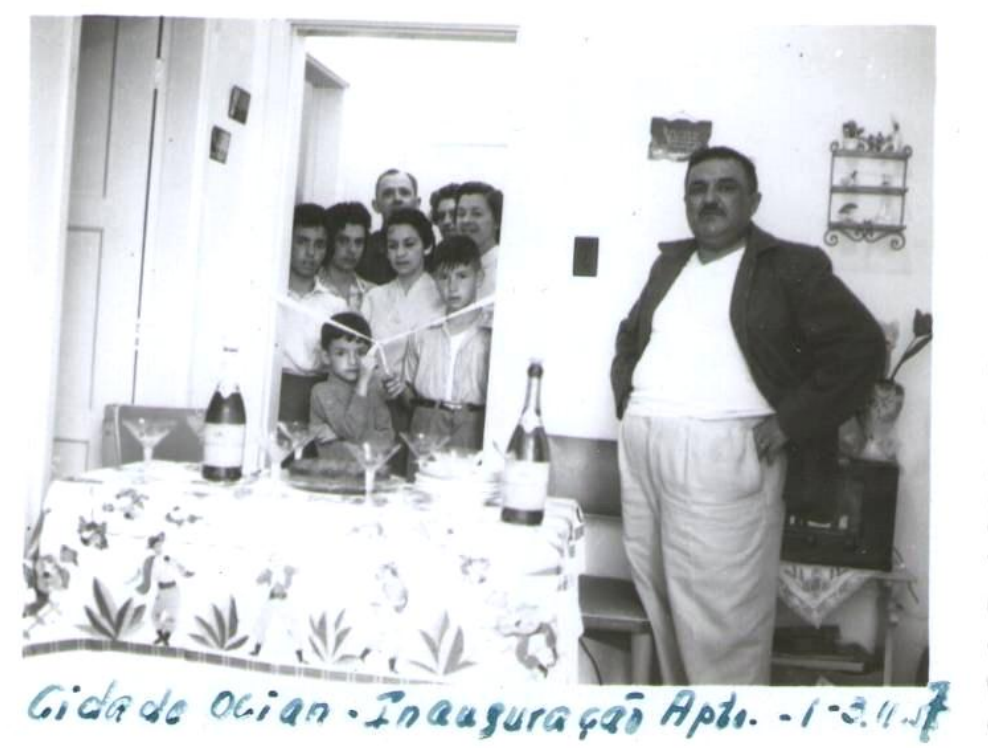

Foto 97: O Sr. Souza em destaque no primeiro plano na inauguração do apto. em Cidade Ocian, 1957. Ampliação das dimensões originais: 6,5 x 9 cm.

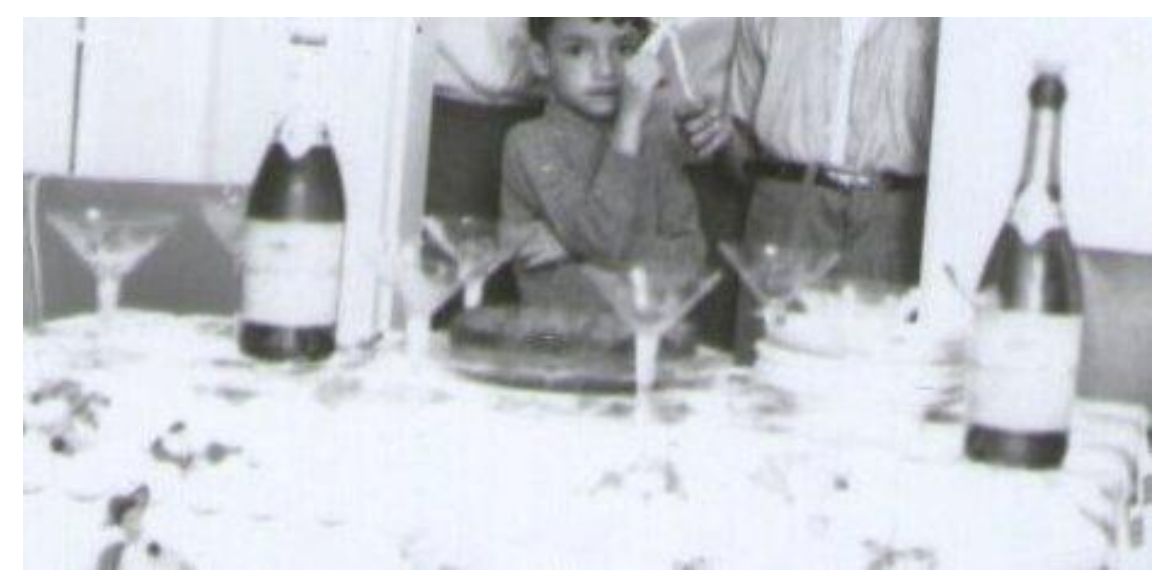

Detalhe 97a: Mesa posta para a inauguração do apto em Cidade Ocian. 1-11-1957.

Tais diferenças são logo dissipadas com a foto 98, e apenas Cleonice está próxima à porta à qual anteriormente estavam familiares e amigos do proprietário. Ocorre, porém, um conflito, sutilíssimo, captado pela câmara. O filho do casal Souza, que segurava uma das pontas da fita, parece estar chateado com o fato de Claúdio concentrar as atenções de alguns adultos. A captação deste pequeno incidente mostra que a residência secundária dá a ver relações que seriam mais comuns ao ambiente emocional doméstico da residência principal. 


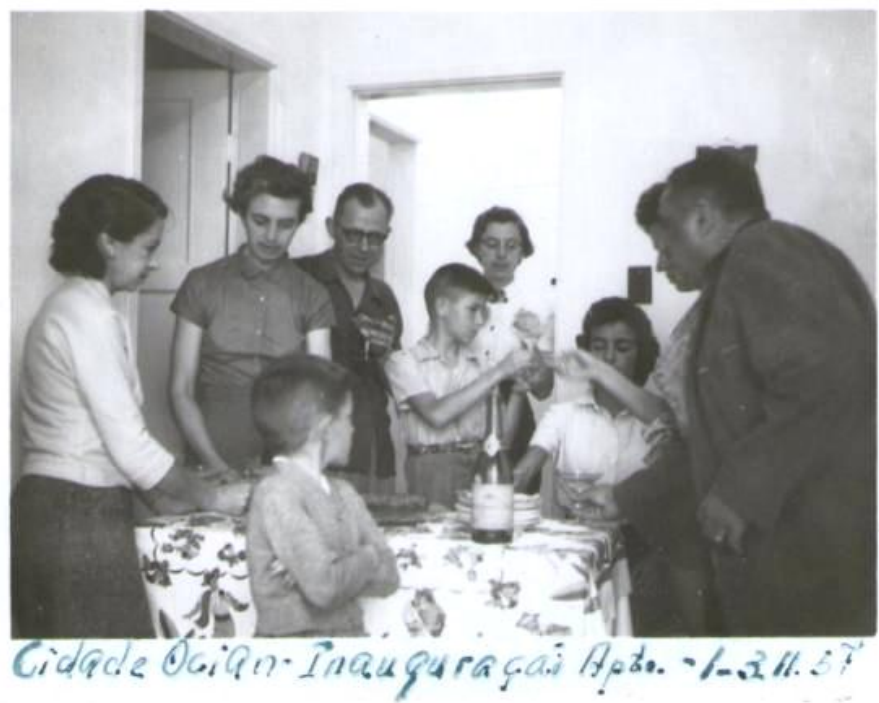

Foto 98: Da esquerda para a direita Olga, Laura, Germano. No centro, em primeiro plano menino anônimo. Ao fundo Claúdio e Cleonice. À direita, Dircinha sentada, mulher anônima e Sr. Souza. Redução das dimensões originais: $6,5 \times 9 \mathrm{~cm}$.

Depois dessa entrada no apartamento em Ocian é hora de descer as escadas em direção à orla da praia, que ficava na frente do edifício São Jorge (foto 99). A letra A, indicada acima do nome do edifício, parece ser uma referência ao bloco de apartamentos onde eles se encontram. Cleonice aparece de pé ao fundo enquanto Dircinha está sentada aos seus pés à direita; seu irmão pequeno está entre ela, uma mulher desconhecida e Dona Olga. Será que essas pessoas sentariam-se à porta do prédio ainda que não fosse para tirar fotografias? 


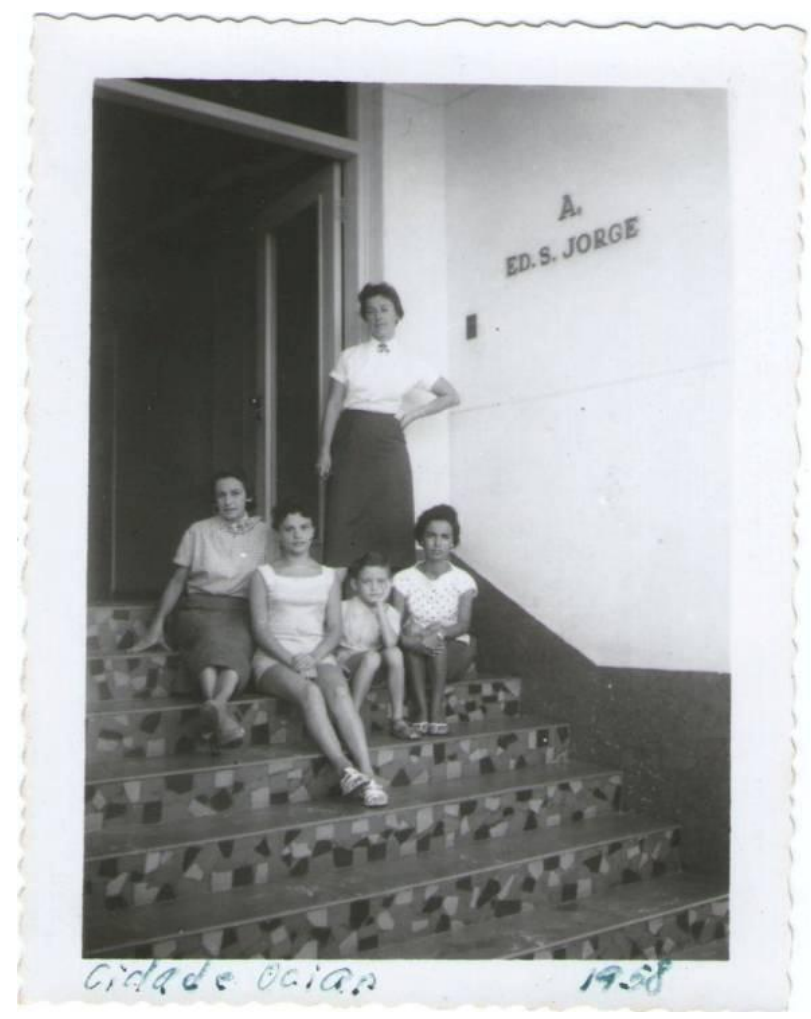

Foto 99: Dona Olga sentada à esquerda ao lado de figura anônima, com o seu filho e Dircinha. Cleonice encontra-se ao fundo de pé. Edifício Cidade Ocian, 1958. Ampliação das dimensões originais: 6,5 x $9 \mathrm{~cm}$.

Mas uma atitude como esta não era malvista, afinal as condutas nas cidades balneárias não estavam completamente normatizadas, tudo era novo: o empreendimento, seus usuários e, obviamente, as formas de se comportar nesses lugares. Tais práticas relatam os usos que essas pessoas fizeram do espaço, modificando-o em relação ao que fora originalmente projetado e ordenado pelos agentes construtores com suas demarcações entre dentro e fora, entre o público e o privado, o coletivo e o individual, o permitido e o proibido. Será que esses agentes de transformação do espaço da praia imaginaram o uso dos degraus da escada para esse fim? Será que os projetaram considerando-os como locais possíveis de intensificação dos laços familiares e de vizinhança? O que os outros habitantes do prédio em 1958 poderiam pensar vendo o grupo sentado nos degraus atrapalhando o trânsito? Talvez o que se verifica nesta foto seja a complementaridade dos comportamentos usuais nos dois ambientes: litoral e capital.

Ao cotejar a ilustração publicitária (figura 10) com a foto 100, podem ser destacados dois diferentes modos de representar o espaço. O primeiro é a forma como os planejadores o conceberam, isto é, enquanto propaganda, aquilo que ainda não existe, 
associando texto e imagem: o sonho da segunda residência realizado através da compra de um apartamento na "maior e mais linda praia do mundo!!!" A visão panorâmica mostra o conjunto de edifícios e das ruas, o paisagismo e, bem ao fundo, a via de acesso direto á praia idealizada por seus incorporadores.

\section{"CIDADE OCIAN" PRAIA GRANDE}

Seu sonho realizado na maior e mais linda praia do mundo!!!

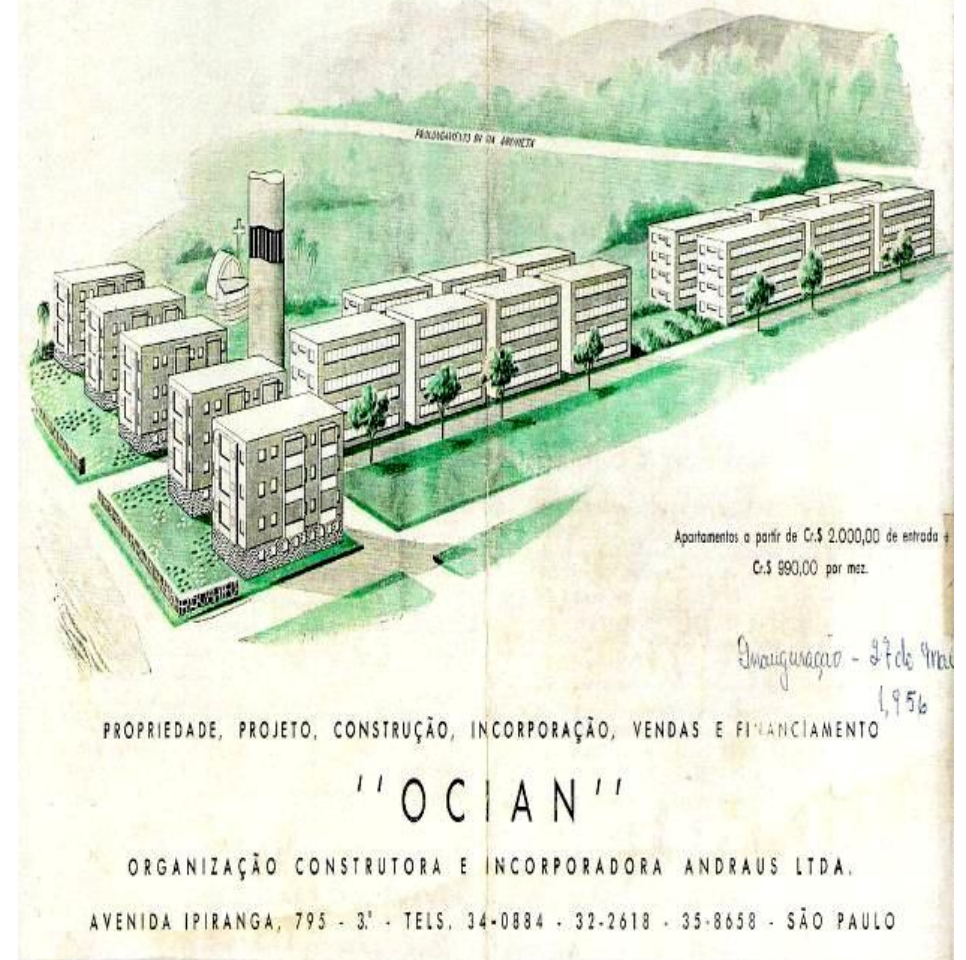

Figura 10: Propaganda do Conjunto Habitacional Cidade Ocian. Fonte: Imário Vieira 2008:126. 


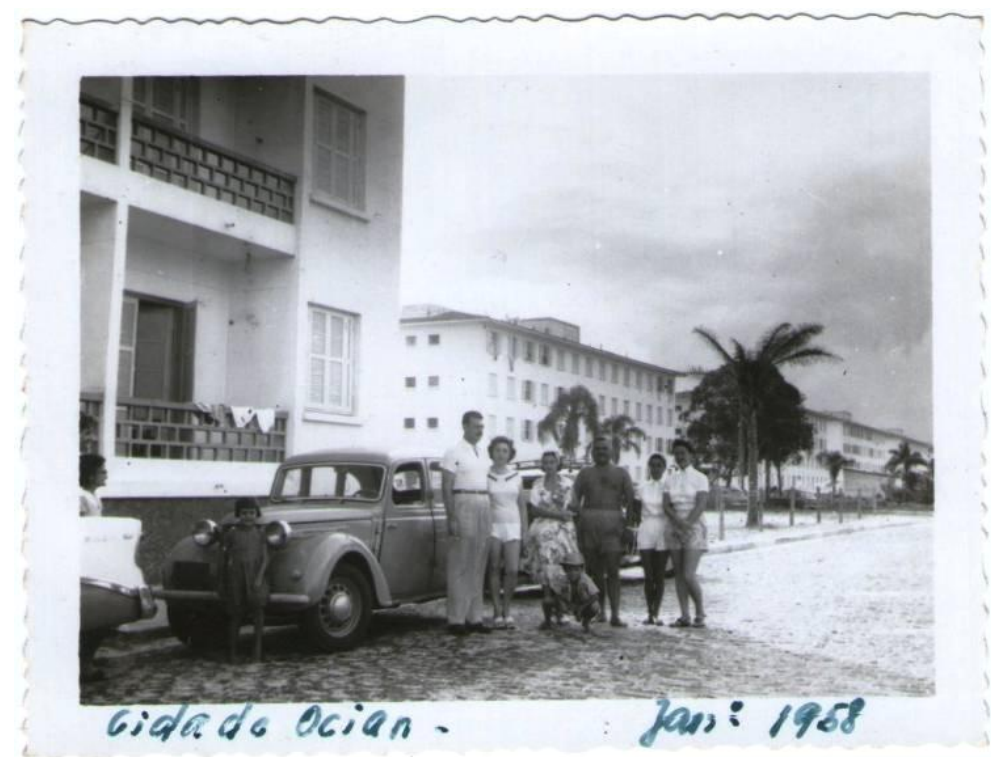

Foto 100: Cleonice à extrema esquerda ao lado da família Souza e casal anônimo. Cidade Ocian, 1958. Ampliação das dimensões originais: 6,5 x $9 \mathrm{~cm}$.

Já a foto 100 parece se opor a essa visão distante, vazia de interações sociais. Figuram ali Cleonice, a família Souza e um casal anônimo criando e conferindo novos sentidos ao espaço projetado pela construtora Andraus. Ao contrário da visão do planejador, o ponto de vista dos turistas é pedestre, talvez a foto tenha sido tirada por alguém que por ali passava. Veem-se roupas na varanda do apartamento térreo. O grupo se encontra perto do mar, bastam alguns passos para que toque os pés na areia, monte ali o guarda-sol e nele se abrigue, mostra a foto 101. As aparições desse objeto balneário começam a surgir na coleção apenas na década de 1950, o que pode revelar mudanças na indústria do lazer praiano. A foto tirada no dia 27/3/60 dá uma noção da distância entre a beira-mar e o conjunto de prédios revelando que eles foram construídos acima do nível da areia, que para acessá-lo as pessoas tinham a opção de usar a escada que aparece ao fundo. 


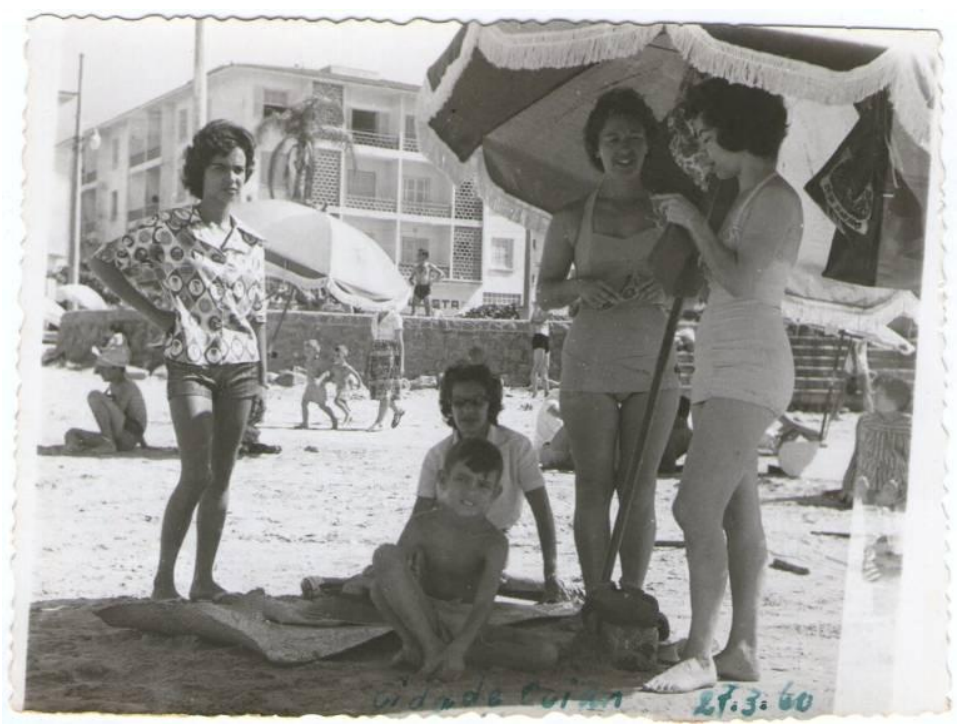

Foto 101: Da esquerda para a direita Dircinha, o irmão, sua mãe, Cleonice e amiga anônima em Cidade Ocian, 1960. Ampliação das dimensões originais: 6,5 x $9 \mathrm{~cm}$.

Mas a orla da praia, como tudo o que se referia ao ambiente litorâneo, estava passando por processos de transformação decorrentes do acesso, cada vez maior de pessoas às praias do litoral santista. Praia Grande começava a tornar-se um dos destinos mais procurados pelos paulistanos, lembremos que já havia ônibus da empresa Cometa direto de São Paulo para Cidade Ocian, conforme detalhe 9 a da propaganda (figura 9).

\section{8) Onibús da Viação Cometa direto de Sāo Paulo à Cidade Ocian.}

Detalhe 9a: Propaganda do Conjunto Habitacional Cidade Ocian. Fonte: Imário Vieira 2008: 127.

As areias da praia eram divididas agora, não somente com veranistas em busca de tranquilidade, mas ainda com novos atores como os umbandistas, que surgiram no cenário a partir dos anos 1950, em uma época na qual a religião começava a ganhar grande projeção nacional e novos adeptos. A praia tornou-se para esses religiosos um local original de manifestação de sua fé que, por ocorrer em espaço aberto e público, atraía curiosos como o fotógrafo. 


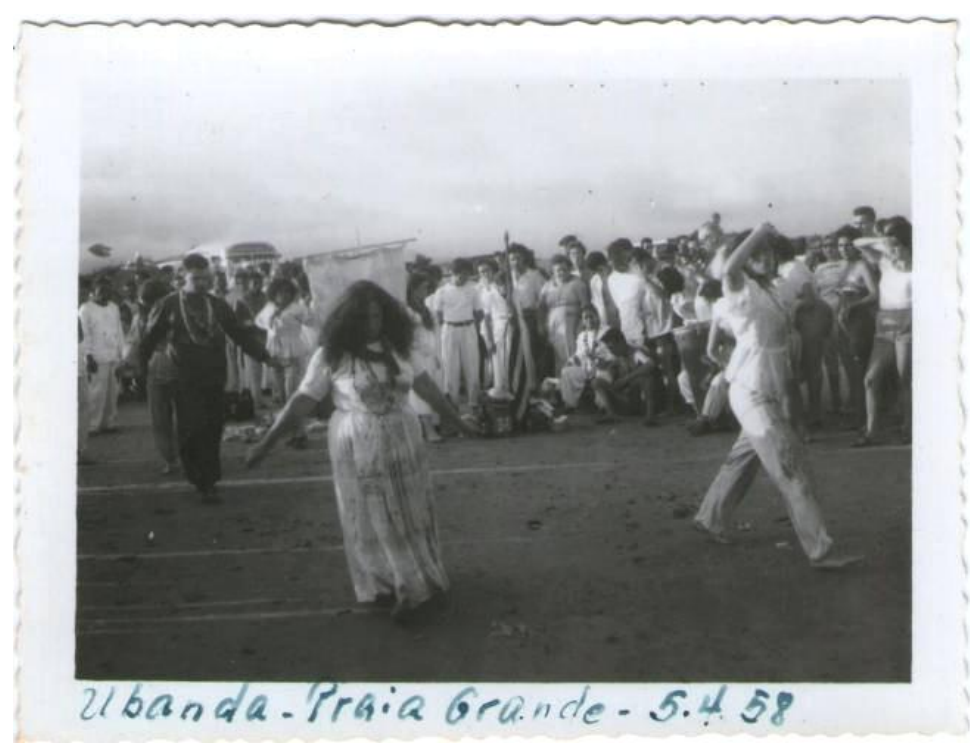

Foto 102: Umbanda - Praia Grande em 1958. Ampliação das dimensões originais: $6,5 \times 9 \mathrm{~cm}$.

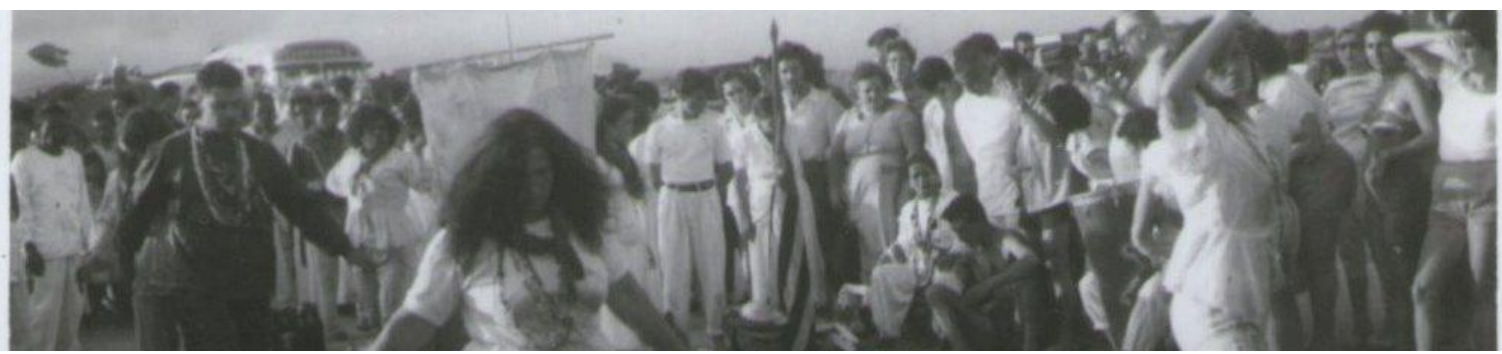

Detalhe 102a: A audiência diante do espetáculo público dos médiuns da umbanda, que com suas práticas religiosas começavam a redefinir o espaço da praia.

Bem ao fundo figura um ônibus (detalhe 102b). Novamente é a facilidade de circulação e a comunicação trazida pela Rodovia Anchieta que possibilitam tal ocupação da praia. Cleonice nem mais ninguém da família Souza aparece na foto. A cena despertou a atenção do fotógrafo e não se tratava aqui (como foi o caso das fotos 84, 85, 86 e 87) do exotismo das pessoas do lugar, mas do exotismo procedente de habitantes da capital, que, como eles, buscavam a praia, o que assinala os diferentes interesses que modelam o espaço litorâneo. 


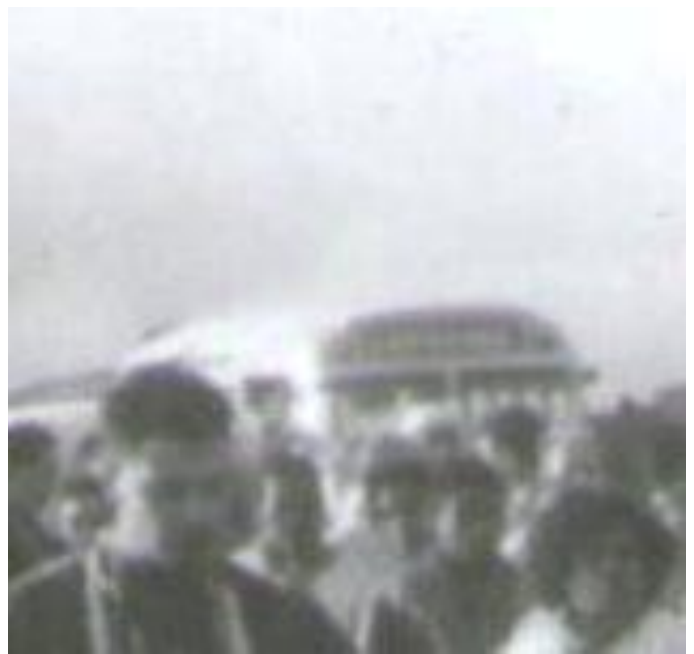

Detalhe 102b: ônibus da Viação Cometa que fazia o percurso São Paulo Cidade Ocian.

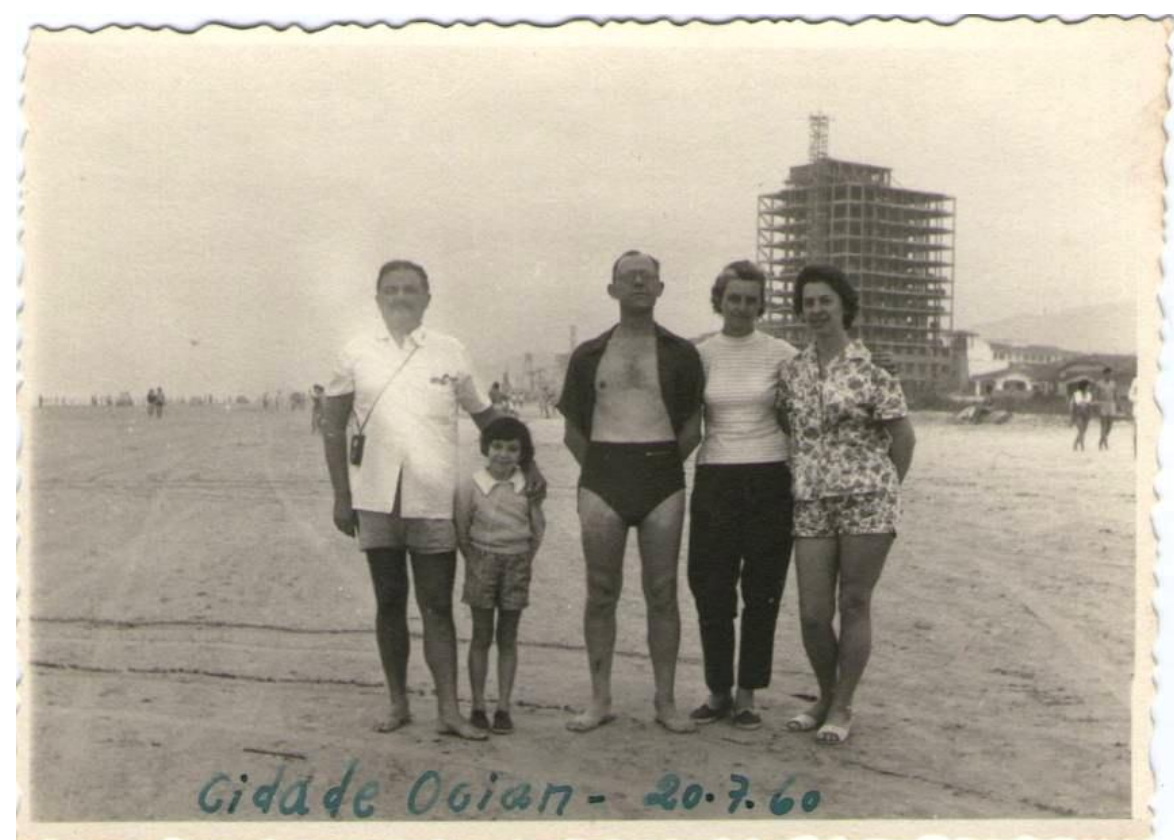

Foto 103: Da esquerda para a direita, o Sr. Souza Filho, uma menina anônima, Germano, Laura e Cleonice Maria Heine em Cidade Ocian em 1960. Ampliação das dimensões originais: $10 \times 7 \mathrm{~cm}$.

A foto 103, escolhida para encerrar esse percurso pelo litoral, mostra a família Heine. À direita, Laura Heine Spinelli está entre o marido e a cunhada, ela os abraça e a fotografia como memória daquele instante sugere o reforço dos laços de afetividade. Lembremos que vinte anos antes, Cleonice já demonstrava afeição por sua cunhada ao lhe oferecer de presente um retrato feito nas Galerias Fotográficas no Edifício Martinelli, (foto 40, cap.1). O Sr. Souza, à direita, está acompanhado de uma criança anônima. Ao observar com cuidado a imagem, pode-se notar a embalagem na qual a 
máquina fotográfica portátil era guardada. Esse retrato pode ter sido feito por alguém que andava pela beira-mar. A grande movimentação de pessoas nas areias da praia fornecia a oportunidade de encontrar estranhos dispostos a apertar o botão e captar a cena, a pose dos modelos e a feição material da cidade que se transformava. Cidade Ocian, bairro que nasceu como empreendimento residencial, começa nesse momento a dividir espaço com novos loteamentos como o enorme prédio de aproximadamente 12 andares que toma a frente de casas construídas anos antes. A praia assemelhava-se assim ao planalto, e grandes edifícios como este eram, sem sombra de dúvida, segundas residências mais sofisticadas que o Edifício São Jorge do empreendimento de Roberto Andraus. Entre as mudanças que estavam ocorrendo, a verticalização talvez seja a mais significativa. Os prédios altos são um símbolo da modernidade e sua ocorrência na paisagem paulistana a partir dos anos 1940, servirá ao que tudo indica, de modelo para o redesenho das cidades litorâneas. Tamanha transformação, era, todavia algo ainda mal consolidado e, nesse sentido, a enorme construção ainda destoava da paisagem do entorno.

Esse elemento novo em Cidade Ocian é "resultado da ação da indústria da construção civil que, em poucos anos, edificou e reedificou quase que totalmente os quarteirões litorâneos" (SEABRA, 1979, 20). O parque imobiliário desta e de outras regiões da Baixada Santista estava passando no exato momento da foto por um surto de crescimento de oferta imobiliária. Crescimento, que, conforme já visto, começou com a novidade trazida por um empreendedor paulistano à região. Esse modelo de ocupação vai redefinindo as funções originais dos locais tornando-os, com o tempo, excessivamente urbanizados. Pode-se destacar o efeito deste crescimento na circulação dos turistas mais antigos que começam a evadir-se a procura de outros lugares onde possam encontrar o mar e a tranquilidade (TULIK, 1996).

Vimos neste capítulo que Cleonice começou a frequentar a praia ainda criança e, com o passar dos anos este destino tornou-se privilegiado, sobretudo quando Cleonice estabeleceu contato com a família Souza. Desta relação dicotômica de trabalho e lazer o grupo experimentou o espaço da praia alojando-se em pensões em diferentes localidades, fez roteiros nos arredores dos alojamentos que conheceram e suas fotos recuperam certos padrões visuais como retratos diante da fachada das construções, registros de ruínas e monumentos históricos, além da movimentação de banhistas. A proximidade entre a capital de onde saíam e o litoral possibilitou ao fotógrafo diversificar o tema das fotos, como, por exemplo, o contato entre visitantes e visitados. 
Finalmente estas imagens captam um conjunto de transformações relativos a intensa comunicação entre o planalto e o litoral que engendrou a circulação de pessoas, coisas e símbolos, cuja fotografia teve intensa participação fornecendo representações e documentando os deslocamentos do grupo. Nesse sentido a fotografia é um qualificador da experiência da viagem e elemento modificador dos lugares visitados, na medida em que recorta e redimensiona o real.

Mas Cleonice e seu grupo não se manteriam exclusivamente na praia, eles consumiram também as cidades de clima ameno e águas miraculosas, que mesclavam saúde e diversão. No próximo capítulo, mostro como a documentação visual dos espaços turísticos de montanha e estações de águas qualifica e, portanto, produz cidades no interior de São Paulo. Afinal, os turistas enquanto consumidores de paisagens necessitam ver novos lugares, sentir seu clima, cotejar seu corpo com o ambiente.

Para chegar a praia, o grupo precisava descer das terras altas do planalto ao nível do mar. Trata-se agora de subir às montanhas em direção a Lindoia, a Serra Negra uma “das mais populares estâncias hidrominerais de São Paulo ${ }^{102 ”}$ e a Campos do Jordão "Jóia incrustada na Serra da Mantiqueira" 103.

\footnotetext{
${ }^{102}$ Revista do Comerciário n.18, setembro-outubro, 1957. p.7. Acervo GEDES SESC Memórias.

${ }^{103}$ Revista do Comerciário n.17, novembro-dezembro, 1957, p.23. Acervo GEDES SESC Memórias.
} 


\section{Capítulo 3: Mapas de deslocamentos: Turismo no campo}

\subsection{Termas de Lindoia}

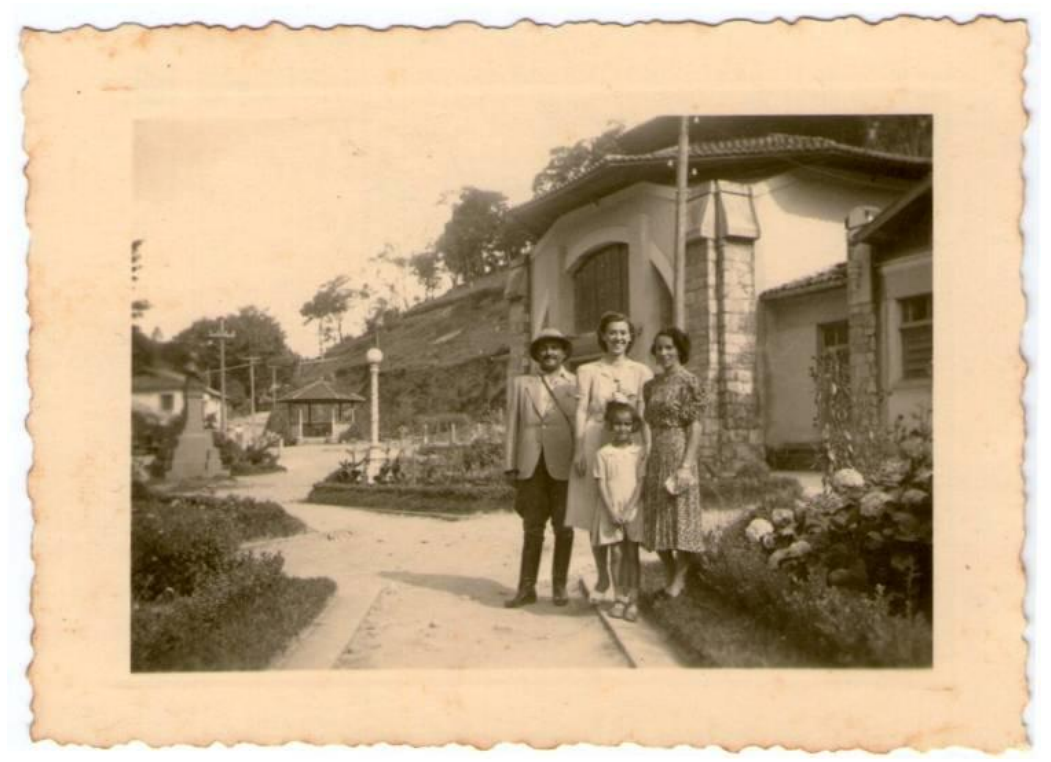

Foto 101: Cleonice e a família Souza diante das Termas de Lindoia. Férias em Serra Negra, 1943. Dimensões: 6 x 9 cm. Papel Agfa Lupex.

A foto acima mostra Cleonice entre o Sr. Souza, Dona Olga e Dircinha. O grupo estava em Lindoya ${ }^{104}$, durante as férias no período de 4 e 18 de abril de 1943. Desse passeio foram feitas 39 fotos, sendo 9 de Lindoia e uma vista dessa cidade a partir de Serra Negra. A proximidade geográfica entre as duas localidades era tão grande que, na identificação feita por Cleonice, ela subordina Lindoia a Serra Negra, quando na verdade até 1938 a segunda estava ligada administrativamente à primeira.

O ambiente campestre foi consumido pelo grupo em visitas a várias cidades, com menor intensidade, se comparada ao litoral. É somente a partir dos anos 1940 que surgiram os primeiros registros do interior de São Paulo. Embora haja evidentemente mais lugares onde Cleonice esteve, dos quais se destacam Atibaia, Águas da Prata, Taubaté, Poços de Caldas (MG), Itatiaia (RJ) entre outros, o recorte escolhido privilegiou apenas as memórias fotográficas de Lindóia, Serra Negra e Campos do Jordão, estâncias hidrominerais e climáticas cuja vocação turística surgiu, antes de tudo,

\footnotetext{
${ }^{104}$ Conforme a grafia usada por Cleonice. Porém, no decorrer do texto, uso a grafia atual.
} 
da relação entre curismo e turismo, ou da busca pela cura de doenças e as experiências de lazer, prazer e diversão.

O grupo chegou à primeira dessas cidades no momento em que acontecia uma transição cultural importante, quando a vocação medicinal original do lugar começou a dar espaço ao incremento do turismo de diversão. Na foto 101, apenas o Sr. Souza usa um traje mais evidentemente associado ao campo: calça, botas, paletó e chapéu, além de sua câmara portátil, melhor visualizada no detalhe 101a, e que deve ter sido emprestada a alguém que andava por ali e fez a foto. Como turistas, eles estavam experimentando as mudanças no comportamento cultural das cidades que visitaram: a passagem gradativa, mas não definitiva, da cura para a cultura do passeio, a difusão dos deslocamentos via automóvel e ônibus, a frequência a estabelecimentos hoteleiros ainda muito novos.

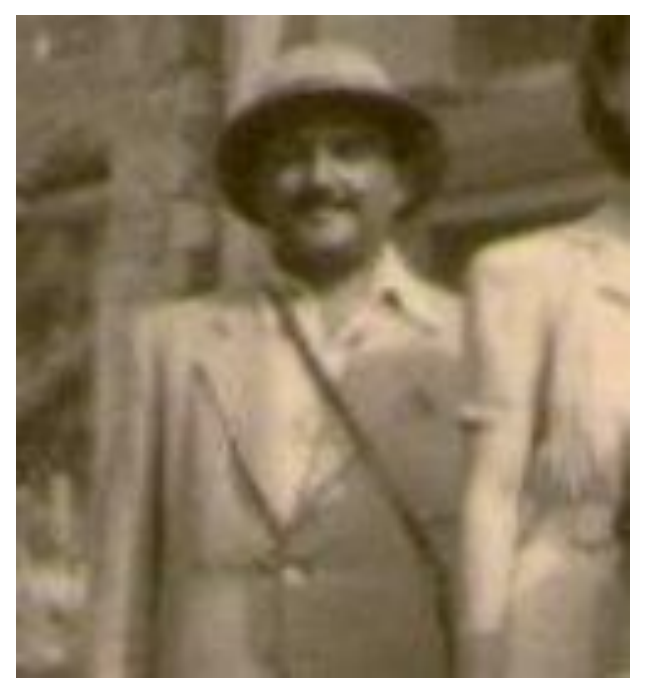

Detalhe 101a: O Sr. Souza com a embalagem da câmara a tiracolo.

No momento em que visitaram Serra Negra eles também conheceram Lindoia, então estância hidromineral famosa por suas termas. A imagem 102, tomada à distância a partir de Serra Negra, revela um aspecto dificilmente visto nas fotografias do litoral: a beleza ecológica da paisagem sem a presença de pessoas. Aqui, a paisagem não é um fundo cenográfico para interações humanas: a imagem valoriza o vale entre as montanhas, cuja beleza distante remete à solidão monocular do fotógrafo amador. 


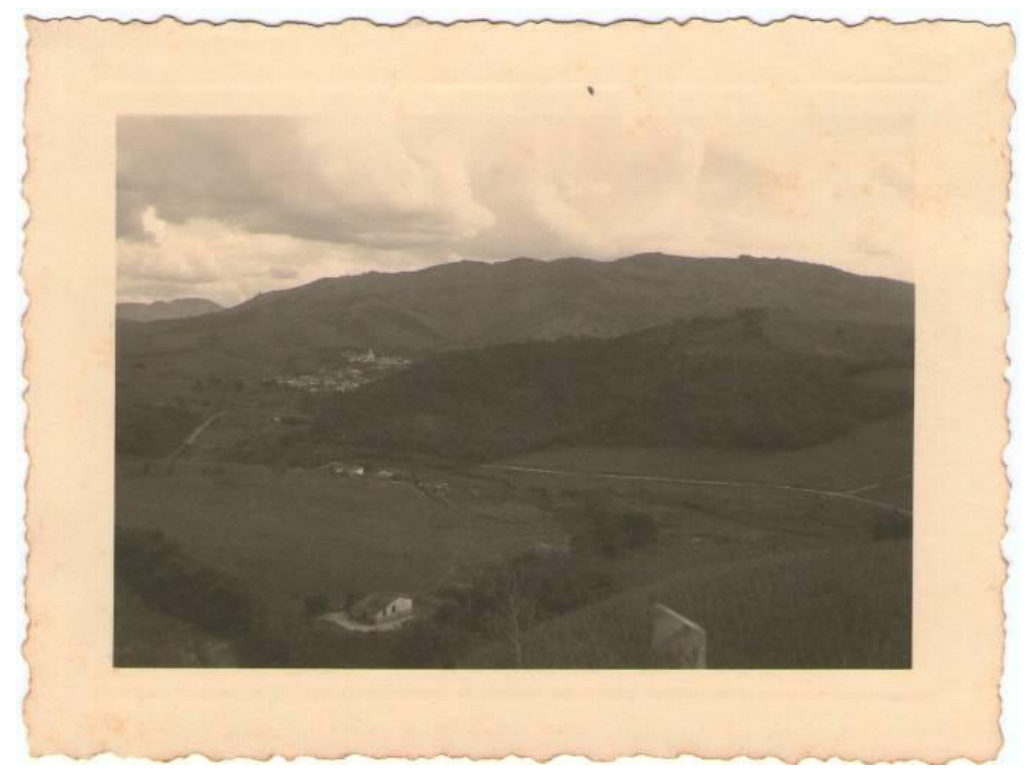

Foto 102: "Serra Negra - Vista cidade de Lindoya", 1943. Ampliação das dimensões originais: 6,5 x 9,0 cm. Papel Agfa Lupex.

A casa longínqua inscrita em cenário pitoresco reafirma, no destino turístico, a oposição campo e cidade urbano-industrial. Embora existissem na capital paulista dos anos 1940 paisagens semelhantes a esta, há grande diferença entre este cenário (em localidade turística com alguma infraestrutura hoteleira), e os elementos de paisagem similar em alguns bairros nos arredores rurais de São Paulo. Aos olhos de quem vivia na área urbanizada da capital nesta época e gozava de condições financeiras para viajar, essa imagem campestre parecia revelar uma beleza incomum. Oportunidade única para uma foto.

O conteúdo da imagem aproxima-se da descrição de Serra Negra no poema de mesmo nome escrito pelo poeta Judas Isgorogota ${ }^{105}$. Alguns elementos comparecem em ambas representações: "A fonte... o céu lá em cima... as casinhas lá embaixo... No fundo, calma e azul, a montanha se ergue..." (Judas Isgorogota, S/D). A cena bucólica captada pela foto é tributária de um ideário romântico que está presente no olhar do turista-fotógrafo, cujo registro contemplativo da paisagem de um local de passeio pode ser um exemplo, tanto quanto o poema. O turista, que se deslocava de uma cidade que crescia física e demograficamente como São Paulo, devia buscar, como vários hoje o fazem, diferentes paisagens naturais e modos de vida diversos do seu. Assim, segundo John Urry, a satisfação do turista está em chegar a lugares que estão fora de sua experiência ordinária (1999). Cleonice está passeando em um momento que coincide

\footnotetext{
${ }^{105}$ Nome artístico do escritor Agnelo Rodrigues de Mello (Al, 1921 - RJ, 1979).
} 
com o início da difusão de uma cultura turística no Brasil, ainda restrita a alguns grupos, é verdade, já que a massificação do turismo se dá apenas a partir dos anos 1960 (BOYER, 2003; SILVA, 2003). Ela não pratica, portanto, o turismo de massa, mas suas andanças situam-se a meio caminho entre a gênese dessa modalidade recreativa e a sua popularização por meio dos automóveis e linhas de ônibus que faziam a ligação entre a capital, o interior e o litoral.

Tomada também à distância e vista de cima, a foto 103 apresenta uma visão do complexo "Termas de Lindóia" revelando o ambiente ecológico no qual elas foram construídas.

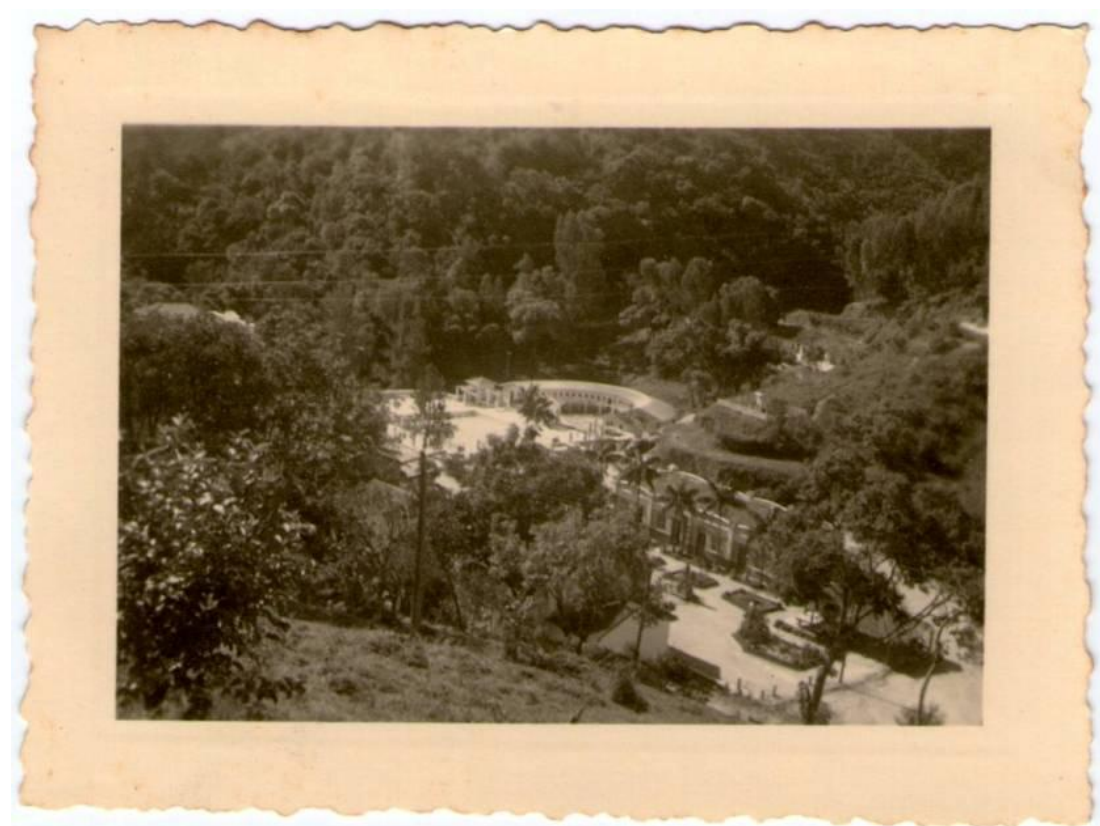

Foto 103: Vista panorâmica das Termas de Lindoya. Férias em Serra Negra. Ampliação das dimensões originais: 6 x 9 cm. Papel Agfa Lupex.

O projeto das Termas de Lindoia foi levado a cabo pelo Dr. Francisco Tozzi ${ }^{106}$ Neste empreendimento, os traços históricos característicos do surgimento das estâncias termais se repetem: crença religiosa, justificativa médica do potencial miraculoso dos elementos da natureza e diversão turística. Conta-se que, um ano antes, quando Tozzi ainda estava na Itália, lhe chegou a notícia de que um seu tio padre havia se curado de

\footnotetext{
${ }^{106}$ (Benevetto, Nápoles 1870 - Rio de Janeiro 1937). As informações sobre o Dr. Tozzi foram extraídas de uma longa entrevista com Miriam Tozzi Bernardino, neta de Francisco Tozzi em um blog disponível em:http://bragamusician.blogspot.com.br/2011/12/ano-internacional-da-quimica-2011-marie.html. Acesso em 20/3/2012.
} 
um eczema de pele ${ }^{107}$ por meio de águas que jorravam a 28 graus do morro conhecido como "Águas quentes". Após análise, o Dr. Tozzi confirma as propriedades terapêuticas daquelas águas, adquire as terras ao redor das fontes e começa a explorar o potencial hidromineral da localidade já em 1910. Tem, pois, início a construção das Termas de Lindoia que começam a funcionar entre 1914 e 1916.

A fama curativa destas águas permitiu a Tozzi, dois anos depois, comercializar a água mineral, que seguia até Serra Negra e era distribuída para outras cidades. Com o bom andamento de seus negócios e a atração que a cidade exercia sobre seus visitantes em meados dos anos 1920, o médico inaugura o Hotel Gloria (foto 104), cuja fachada aparece à esquerda. Em 1926, o Dr. Tozzi, sabendo que Marie Curie ${ }^{108}$ estava em visita ao País, convidou-a a conhecer a cidade.

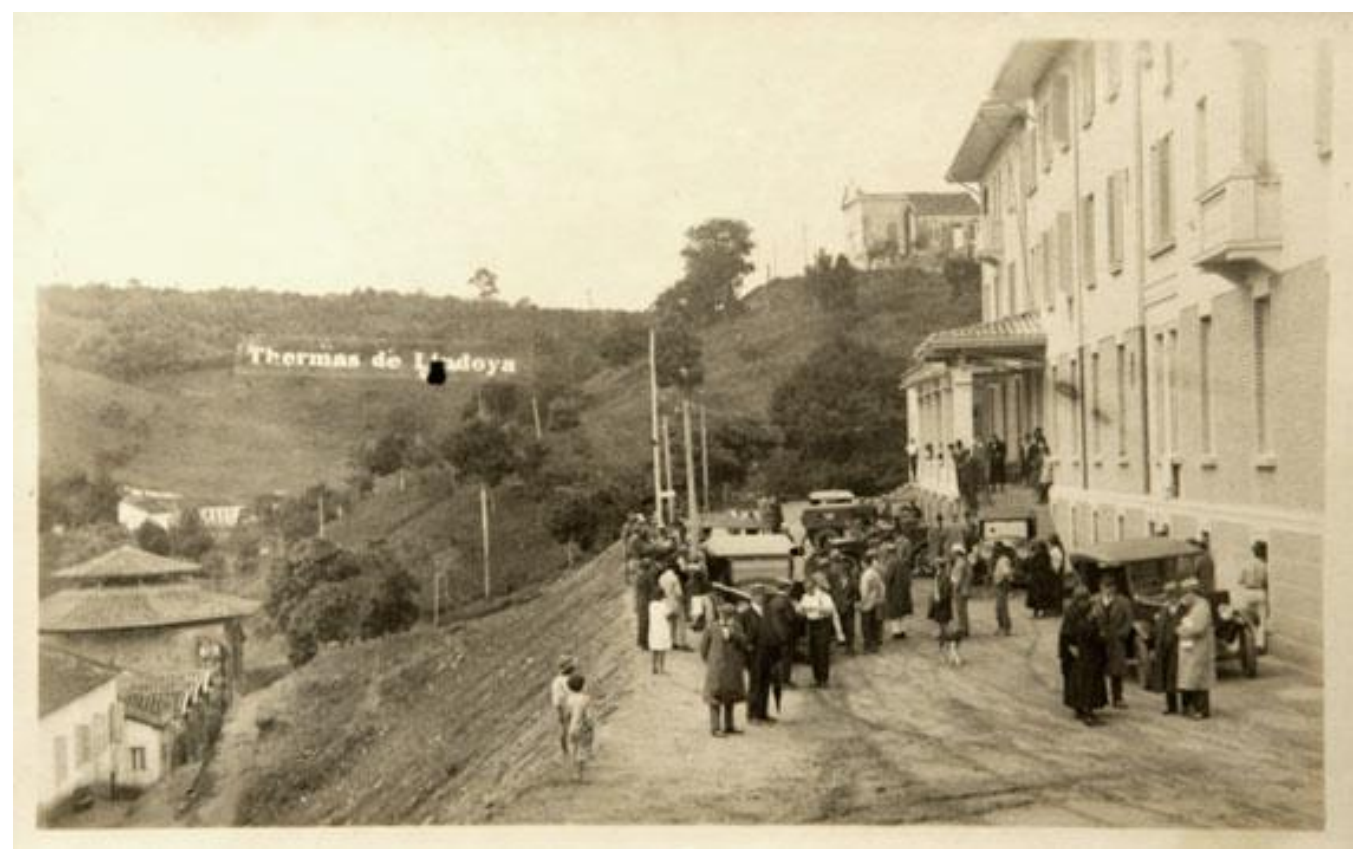

Foto 104: Hotel Glória em meados dos anos 1920. Fonte: Arquivo Miriam Tozzi apud Conselho Regional de Química IV região ${ }^{109}$.

A cientista estrangeira, acompanhada dos químicos de São Paulo, tão logo chegou seguiu para o Hotel Glória. Tozzi ofereceu um "almoço festivo" e "inaugurou oficialmente um retrato de Marie Curie em um de seus salões". Foi assim que "Madame

\footnotetext{
${ }^{107}$ Muito da capacidade curativa das águas especiais está associada a problemas de pele ou problemas reumáticos. Para o assunto consultar: QUINTELA, (2004); BASTOS, (2011). Porém, como nota MOURÃO “toda água mineral possui uma personalidade terapêutica”. (1997: 259).

108 Cientista polonesa (Polônia, 1867 - França, 1934). Precursora junto com seu marido das pesquisas sobre radiação, duas vezes premiada com o prêmio Nobel.
} 
Curie e sua filha conheceram os hotéis, os pavilhões de banho, os locais de engarrafamento das águas, as fontes Filomena e São Roque e os salões de emanações" ${ }^{110}$. Portanto, na história desta localidade misturam-se ciência médica (a radiotividade da fonte descoberta e suas capacidades para curar doenças), religião (evidente no nome da fonte São Roque) e diversão (Hotel Glória).

O nascimento desse lugar como pólo turístico ocorre em condições de transformações culturais importantes que promoveram o consumo do ar, da luz solar e, sobretudo, da água, elementos fundamentais para a saúde, fazendo com que localidades com essas características dessem origem simultaneamente a estâncias de curismo médico e de turismo mundano (MARRAS, 2004; QUINTELLA 2004a; 2004b; 2011). Essa dicotomia não só é parte da cultura termal há milênios, como mostra que a frequência a essas localidades nunca foi exclusivamente terapêutica, isto é, a diversão sempre acompanhou a cura (RODRIGUES, 1985). Durante o Império Romano, por exemplo, as thermas tinham dupla função: curar e revigorar as tropas, além de atender a população local proporcionando "às famílias ricas um conjunto de facilidades destinadas, sobretudo ao repouso e ao divertimento" (BARREIRA e SILVA, 1994:14). Em cidades desse tipo, são as especificidades naturais que as tornam um destino desejado de consumo. Com o desenvolvimento da medicina moderna, nas primeiras décadas do século XX, por sua vez, o poder dessas águas foi cientificamente explicado.

É exatamente o que ocorre com Lindoia nas figuras de Tozzi e de seu tio padre. Esse médico seguia uma tendência que vinha se afirmando no campo científico, pois a hidrologia e a crenologia ${ }^{111}$, então novos campos de conhecimento, passaram a gozar de grande prestígio (MOURÃO, 1997). Também em Serra Negra, cidade irmã de Lindóia, uma fonte radioativa daria ensejo a novos empreendimentos comerciais.

\footnotetext{
${ }^{110}$ Mais dados sobre a passagem de Marie Curie por esta cidade estão disponíveis em: http://crq4.org.br/default.php?p=texto.php\&c=quimicaviva_mariecurie brasil Acesso em 20/3/2012.

${ }^{111}$ Segundo definição de Benedictus Mourão, a crenologia trata das "águas mineromedcicinais em suas aplicações práticas, na prevenção e tratamento de várias entidades mórbidas, ela é uma das divisões da Medicina Física especificamente a Hidrologia que estuda as águas em geral. (1997: 247).
} 


\subsection{Serra Negra e o Rádio Hotel}

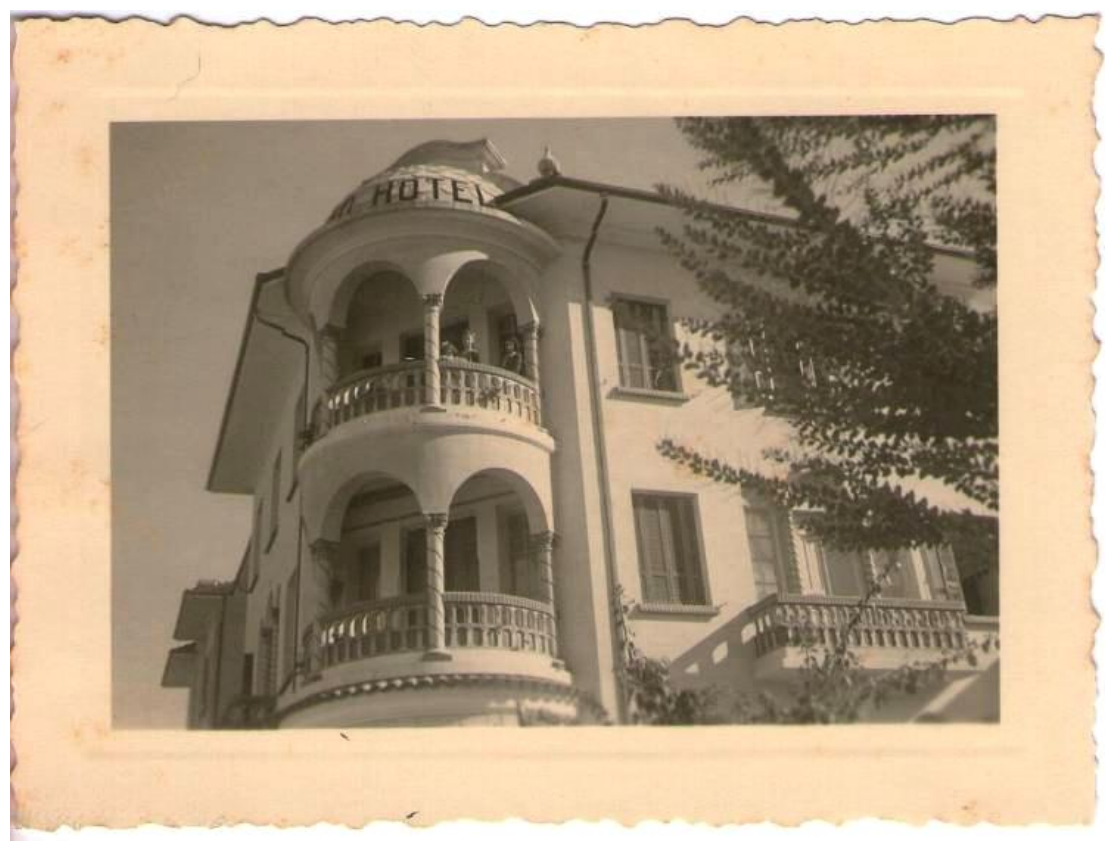

Foto 105: Fachada do Rádio Hotel.

Em 1928, o Dr. Francisco Tozzi presenteou Serra Negra com um monumento ${ }^{112}$; essa atitude era um reconhecimento à recente descoberta de uma fonte radioativa na cidade. Conta-se que Luiz Rielli ${ }^{113}$ descobriu águas altamente radioativas em terreno de sua propriedade na qual ele construiu mais tarde um complexo hoteleiro chamado Rádio Hotel (foto 105). O Rádio Hotel nasceu da parceria entre o Sr. Rielli, o Dr. Jovino Silveira e seu pai, um fazendeiro abastado (BORIN, 2002: 35). Segundo o jornal Cidade de Serra Negra:

Integravam o patrimônio desse estabelecimento: um parque ajardinado (ao lado, posteriormente, foram construídas piscinas), a Fonte Santo Antônio, cujas águas radioativas tinham sido descobertas por Rielli, em 1928, e, nos fundos, uma mata com flores ornamentais. O Rádio Hotel mantinha um departamento com aplicações balneoterápicas ${ }^{114}$.

O estilo dessa arquitetura está ligado à presença daqueles primeiros imigrantes italianos que vieram para o Brasil em fins do século XIX, alguns dos quais (como Tozzi

\footnotetext{
${ }^{112}$ Não encontrei nenhuma imagem deste monumento ou qualquer referência mais precisa.

${ }^{113}$ Uma breve biografia deste personagem de Serra Negra é contada na internet e pode está disponível em: http://jornalcidade.circuitodasaguas.com/historico/ler.php?id=5292 Acesso em 2/11/2011

${ }^{114}$ Disponível em: http://jornalcidade.circuitodasaguas.com/historico/ler.php?id=4337. Acesso em 22/12/2011.
} 
e Rielli) e século XX. Esses imigrantes traziam o conhecimento clínico/científico a respeito das águas, além do catolicismo, e recriavam aqui cenários de clara inspiração europeia, até porque era o termalismo europeu que inspirava o surgimento dessa infraestrutura a um só tempo religiosa, medicinal e turística.

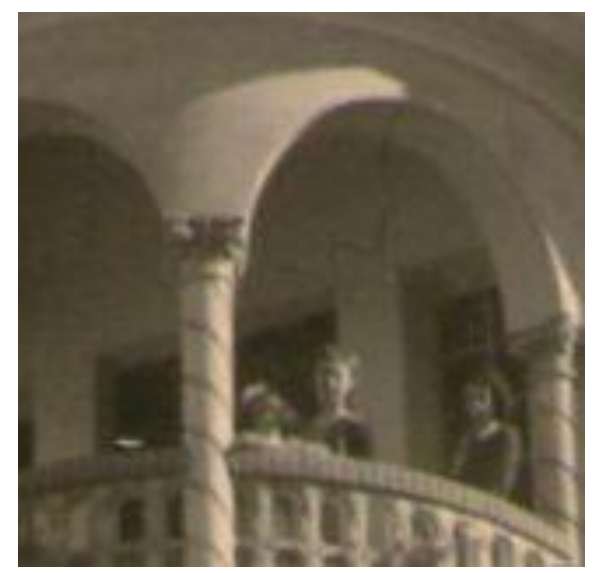

Detalhe 105a: Cleonice, entre Dircinha e Dona Olga, na sacada do Rádio Hotel em 1943.

O detalhe 105a mostra a varanda do hotel de três andares, vista de baixo para cima $^{115}$. Provavelmente, o grupo está na sacada do quarto em que estão hospedados, no terceiro andar. Esta área localizava-se no que parece ser a face principal do Rádio Hotel, pois o letreiro com a palavra "Hotel" figura logo acima. A separação deste detalhe permite ver, ainda que imprecisamente, a criança e as duas mulheres que olham para baixo: Dircinha, Cleonice e Dona Olga. A menina está bem próxima a Cleonice enquanto a mãe coloca-se mais ao fundo.

O incremento da infraestrutura turística da cidade a partir da construção do Rádio Hotel indica que estava em desenvolvimento uma cultura do lazer, ainda que em seus primórdios, capaz, no entanto, de substituir o café, cujos efeitos sobre a cidade desde a crise de 1929 foi o decrescimento de sua população ${ }^{116}$. Se muitas das pessoas aí estabelecidas debandavam para a capital em busca de oportunidades de trabalho, os turistas com disposição financeira para o consumo de paisagens faziam o caminho contrário em busca de sossego, repouso, "intensa insolação, clima sêco e temperado, ricamente oxigenado" 117 .

\footnotetext{
${ }^{115}$ Conforme a Revista do Comerciário o hotel tinha em 1958 "três andares de quartos e apartamentos, salas de leitura no térreo, ping-pong, salão de festas, refeitórios de adultos e crianças". Ver: Revista do Comerciário n.18, novembro-dezembro, 1957, pp.4-6. Acervo GEDES SESC Memórias.

${ }^{116}$ Cf. MONBEIG, ([1949], 1998: 258).

${ }^{117}$ Revista do Comerciário n.18, novembro-dezembro, 1957, pp.4-6. Acervo GEDES SESC Memórias.
} 


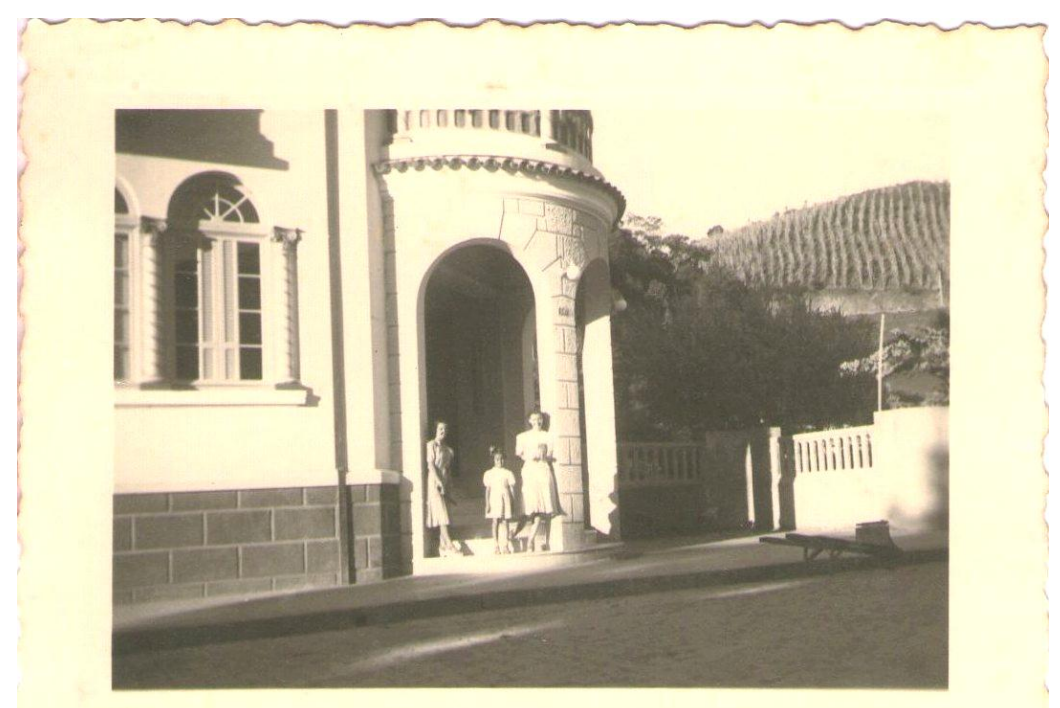

Foto 206: Dona Olga, Dircinha e Cleonice na entrada do Rádio Hotel.

Na foto 106, espécie de complemento da tomada de baixo para cima anterior, as três figuras estão agora no térreo. Com esses registros o fotógrafo descreve alguns aspectos da construção, inserindo na cena o seu grupo. É como se, pela imagem, a construção fosse se constituindo por meio dos fragmentos fotográficos: a fachada com varanda, o andar térreo. Na foto 107, por sua vez, o hotel é visto a partir de uma posição superior e a distância de maneira que o ângulo da tomada privilegia o conjunto arquitetônico. O motivo da imagem parece ser a fachada do alojamento construído entre as montanhas ao fundo.

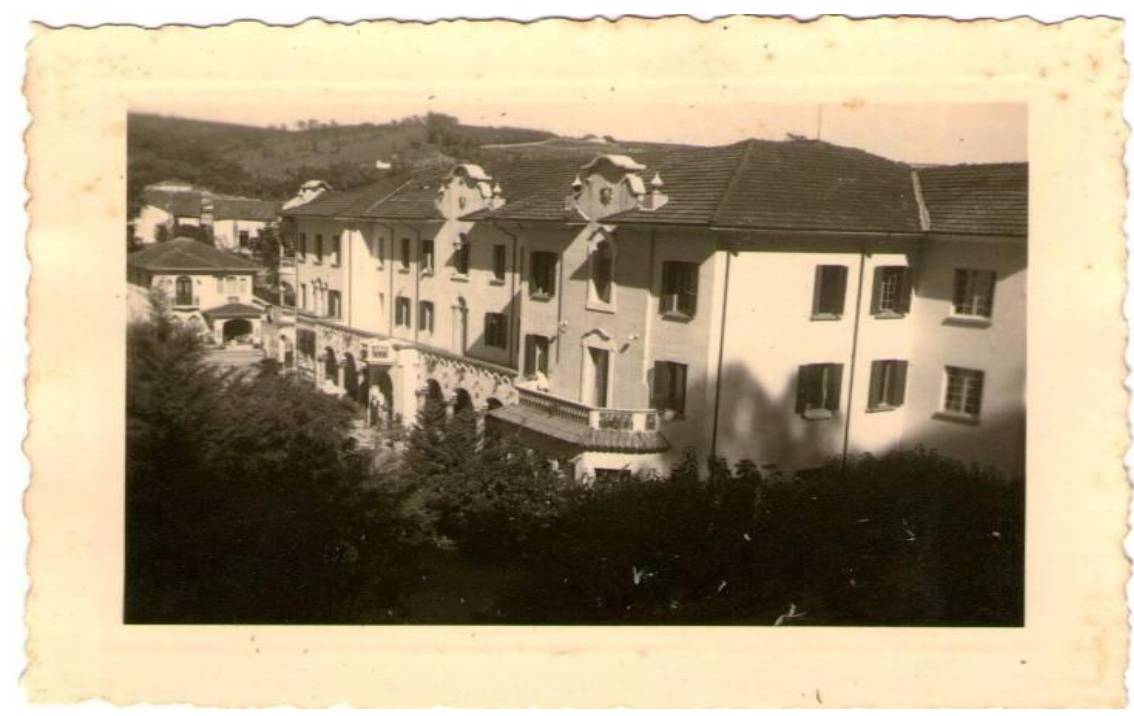

Foto 107: O Rádio Hotel visto à distância em 1943. Ampliação das dimensões originais: 6 $x 9$ cm. Papel Agfa Lupex. 
A ampliação de um detalhe permite notar que o grupo que estava na varanda (foto 105), que desceu (foto 106) - não é possível saber em qual sequência as fotos devem ser olhadas -, está agora também em uma das portas do edifício, detalhe 107a, de maneira que ver a arquitetura parece ter sido apenas um pretexto para a visualização do grupo.

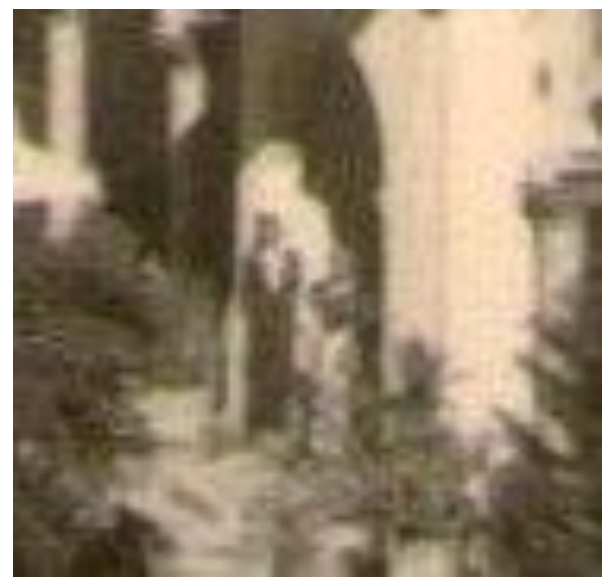

Foto 107a: Cleonice, Dona Olga e Dircinha no detalhe, em uma das entradas do Rádio Hotel.

Entre as atrações "turísticas" que o hotel oferecia estava a capela erigida sob a fonte radioativa em homenagem a Santo Antônio (fotos 108 e 109).
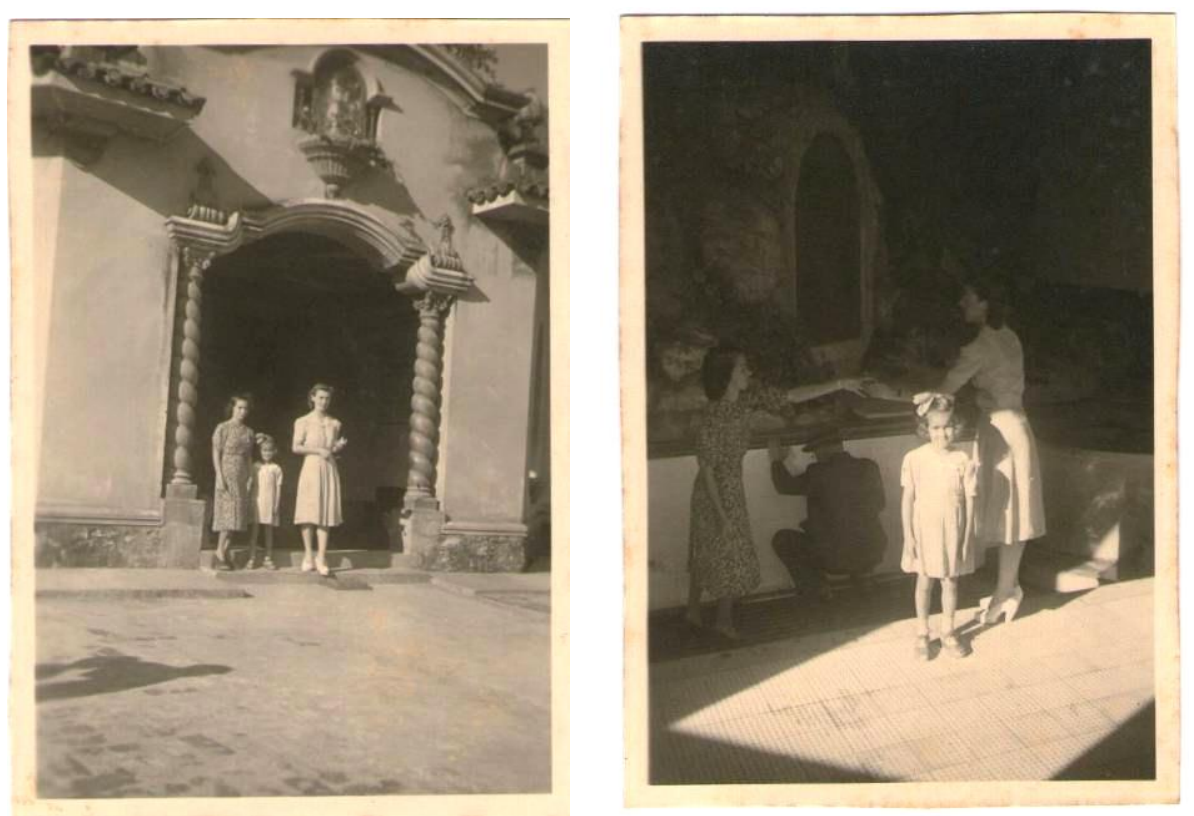

Fotos 108 e 109: Olga, Dircinha e Cleonice e em Serra Negra respectivamente diante da fachada e no interior da capela em 1943. Dimensões: 5, 5 x 7,5 cm. Papel Agfa Lupex. 
Cleonice, à esquerda de Dona Olga e Dircinha, posa na entrada da capela (foto 108) e o grupo ocupa porção importante da composição. Todavia, a pose é bastante convencional se comparada à foto 109 , em que a interação entre as duas mulheres resulta em composição mais dinâmica, inclusive em razão do jogo de luzes e sombras que ressalta a figura de Dircinha em toda a área iluminada da foto. No detalhe 109a, pode-se notar que Dona Olga estende os braços para Cleonice como se pegasse algo de suas mãos. Forma-se assim um triângulo entre a menina em primeiro plano e as mulheres ao fundo, um tanto indiferentes ao momento do clique no qual elas saíram compartilhando um gesto, uma conversa corporal, próximas à fonte miraculosa cujo nome homenageava um santo como já acontecera a Lindoia.

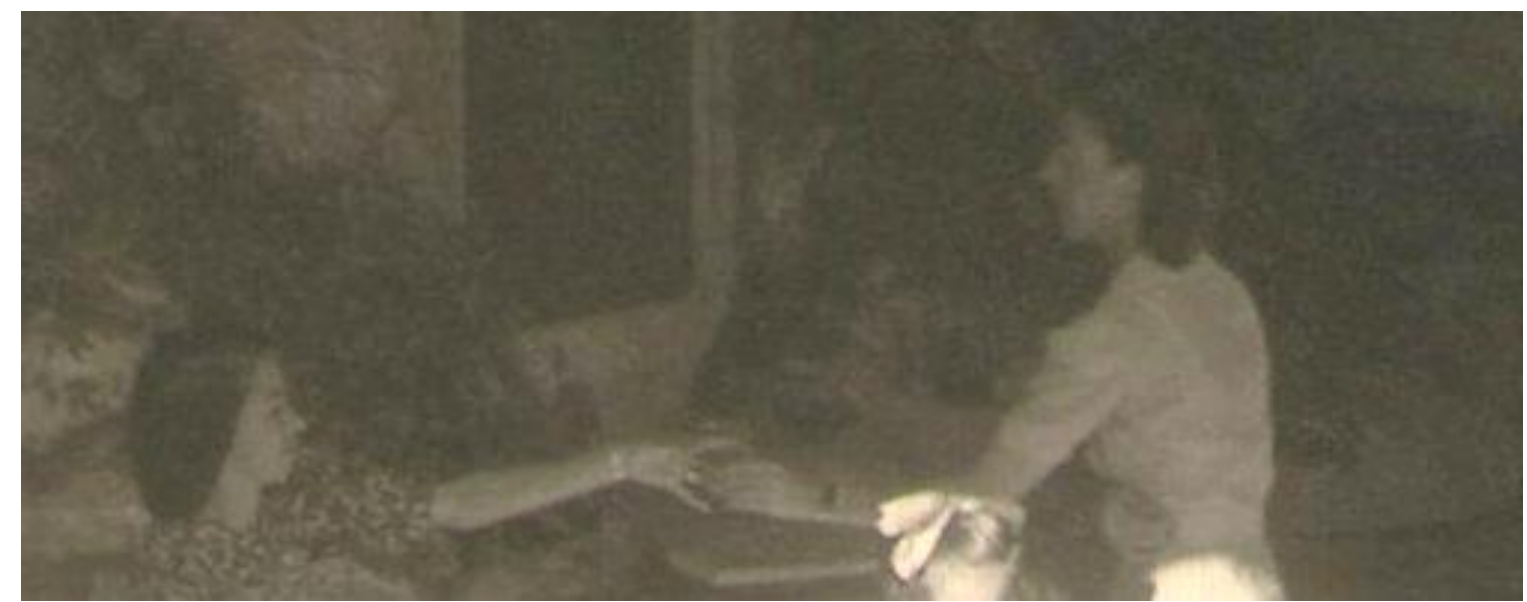

Detalhe 109a: Dona Olga, à esquerda, estende sua mão a Cleonice.

O hábito de dar o nome de santos católicos a fontes radioativas, segundo Benedictus Mário Mourão, advém do papel que estas assumiram na Idade Média. A imaginação popular via essas fontes como milagrosas e, envolvidas em mistérios, o que as levava a exigir a proteção de santos e santas (MOURÃO, 1997). Em plena fase clínico-científica $^{118}$ revitalizava-se a prática antiga de identificar a fonte descoberta com um nome de santo. Tal prática pode ser interpretada segundo a noção de "circularidade" tal como a utiliza Carlo Ginzburg para descrever as trocas entre os circuitos "populares" e "eruditos". (GINZBURG, 1991). No contexto de Lindoia e Serra Negra dá-se um relacionamento circular entre medicina popular e erudita; pode-se afirmar que a crença religiosa no poder das águas e sua posterior justificação clínica por meio da comprovação científica e racional, se influenciam reciprocamente.

${ }^{118}$ Segundo QUINTELA (2004a) essa fase corresponde no Brasil às primeiras décadas do século XX quando médicos reinvindicaram a criação da disciplina de hidrologia médica nas faculdades de medicina. Os anos 1930 e 1950 foram, segundo MOURÃO (1992) o período aúreo do termalismo clínico brasileiro. 
$\mathrm{Na}$ área construída do Rádio Hotel, a fonte Santo Antonio ficava no térreo ${ }^{119} \mathrm{e}$ alimentava a piscina dos banhistas, provavelmente a mesma que figura em uma vista panorâmica (foto 110).

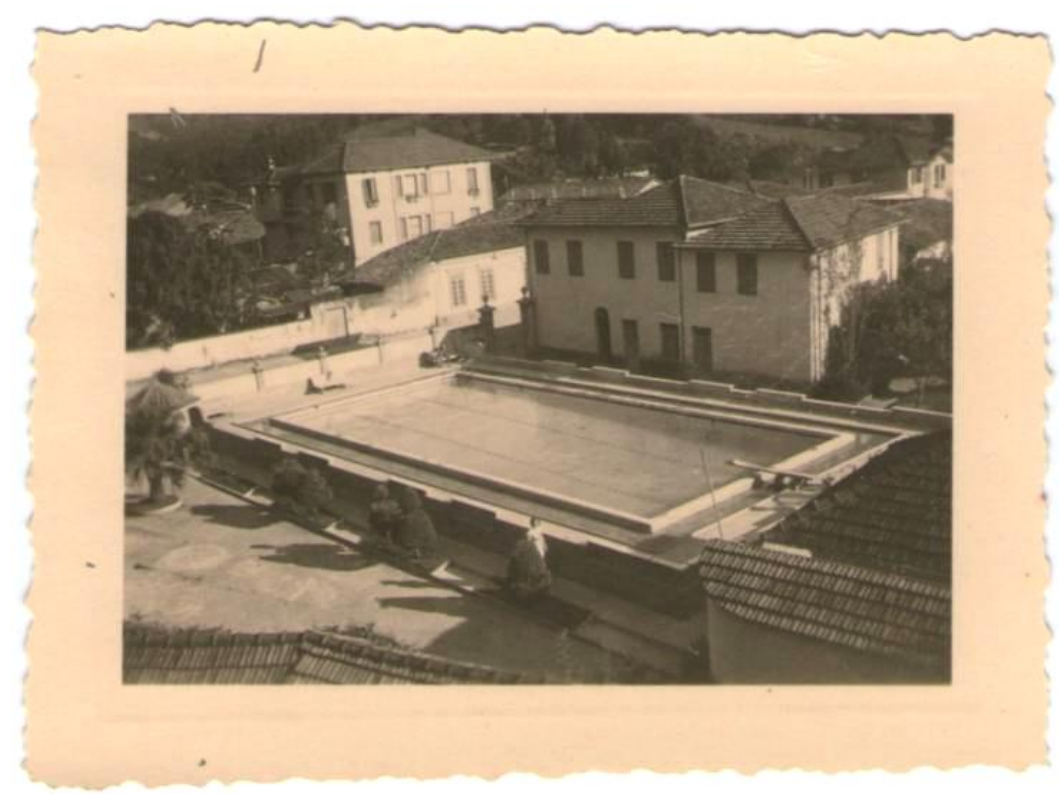

Foto 110: Vista panorâmica da piscina do Rádio Hotel, 1943. Ampliação a partir das dimensões originais: 6 x $9 \mathrm{~cm}$. Papel Agfa Lupex.

Inicialmente, o registro, tomado do alto e à distância, parece mostrar apenas parte da infraestrutura do hotel com a piscina de água terapêutica e, por que não, divertida, recreativa e turística. Ao recortar um detalhe (110a) é possível ver no canto inferior direito uma pessoa andando sozinha próxima à piscina. Trata-se de Cleonice, vestida de roupa clara como nas fotos 108 e 109.

\footnotetext{
${ }^{119}$ Revista do Comerciário n.18, novembro-dezembro, 1957, pp.4-6. Acervo GEDES SESC Memórias.
} 


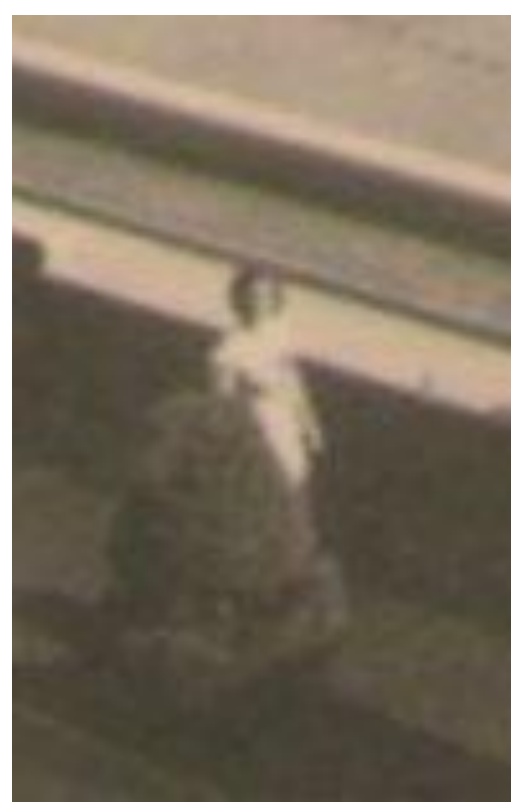

Detalhe 110a: Cleonice perto da piscina do Rádio Hotel.

Com a digitalização, não só é possível ampliar razoavelmente o artefato como também extrair partes importantes dele para o exercício de aprender a ver formatos fotográficos de pequenas dimensões. É interessante notar, neste caso que, mesmo sabendo que a pessoa fotografada seria miniaturizada ao extremo (ficando até sem expressão facial), fotógrafo e modelo insistem em fazer a foto, mesmo com limitações tecnológicas: ela na pose, ele na tomada; não parece exagerado afirmar haver aí uma cumplicidade. Além disso, diante da quantidade de representações que acumulou de si mesma, permitindo-se inclusive fazer imagens distantes como esta, me faz pensar que Cleonice estivesse disposta a imaginar-se como imagem, ainda que quase invisível na composição, ela deixa evidente que gostava destas representações.

O Rádio Hotel também aparece associado a um acidente pedestre. A insólita foto 111, se olhada dissociada da legenda no verso, perde completamente o sentido, pois não dá qualquer indicação de que seja um fragmento da área exterior do hotel. Trata-se de uma imagem aparentemente gratuita, cujo sentido só se esclarece quando lemos na legenda: "Lugar onde caí no Rádio Hotel”. A foto é um enigma, pois não fica claro se foi o fotógrafo, Sr. Souza, que fez o registro lembrando uma queda sua, ou se foi Cleonice, que, após a queda, fez ela mesma a foto, ou pediu a ele que o fizesse para guardar a memória de passos dados em falso. 


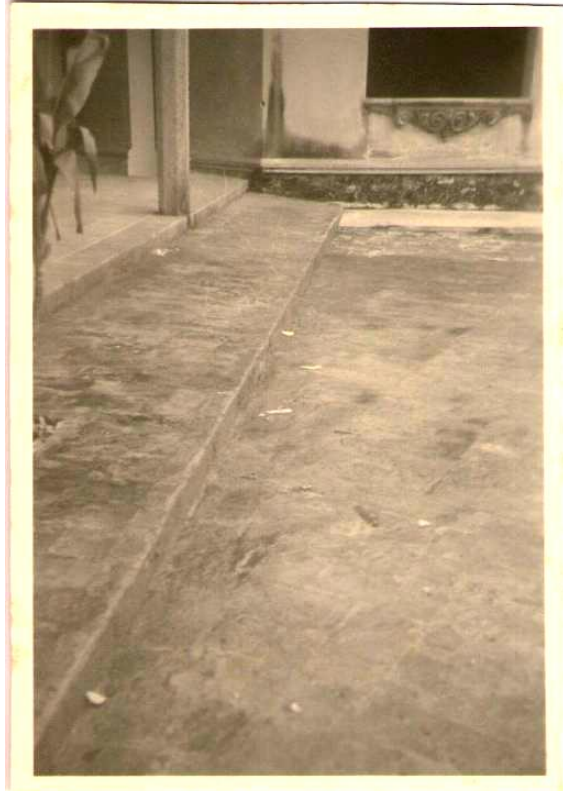

Foto 111: Fotografia do piso externo do Rádio Hotel.

Dimensões 8,0 x 5,5 cm. Papel Agfa Lupex.

Nesse caso, o objeto fotografia funciona como um "microrrelato de espaço" que submete o lugar - o Rádio Hotel - à experiência de um hóspede: a queda torna-se algo engraçado, transformando o evento acidental em fato digno de ser relembrado. Quem sabe Cleonice não levou um tombo justamente quando olhava para fotógrafo?.

De modo semelhante a Lindoia, Serra Negra começava a atrair visitantes ilustres. Em 1928, Washington Luís ${ }^{120}$, governador de São Paulo de 1920 a 1924, e presidente do Brasil de 1926 a 1930, deu-lhe o título de "Cidade da Saúde". A circulação de políticos nesses e outros lugares de turismo alimentava a moda das estâncias hidrominerais.

Stélio Marras revela que Getúlio Vargas ${ }^{121}$ frequentava a famosa cidade de Poços de Caldas e comenta, a propósito de uma foto do estadista:

Descontração terapêutica ou política? Suas oportunidades na estância não se resumiam, contudo, ao descanso e aos divertimentos. Muitas vezes era lá mesmo que despachava serviços presidenciais, atendia e articulava. A presença do grande estadista nas estações alimentava a moda (2004: XXXVI)

Tanto Washington Luís quanto Vargas ajudaram a definir o destino turístico de algumas cidades brasileiras que começavam a fomentar o consumo do tempo livre, por meio de seus atrativos naturais. Para tais lugares, pois, acorriam diferentes tipos de pessoas com interesses diversos dos famosos. Embora estivesse longe de ser uma

\footnotetext{
${ }^{120}$ (Washington Luís Pereira de Sousa RJ, 1869 - SP, 1957).

121 (Getúlio Dorneles Vargas, RS, 1882 - RJ, 1954).
} 
celebridade, Cleonice estava consumindo o que então era moda e referendado por personagens, eles sim célebres.

\subsection{O Grand Hotel de Serra Negra}

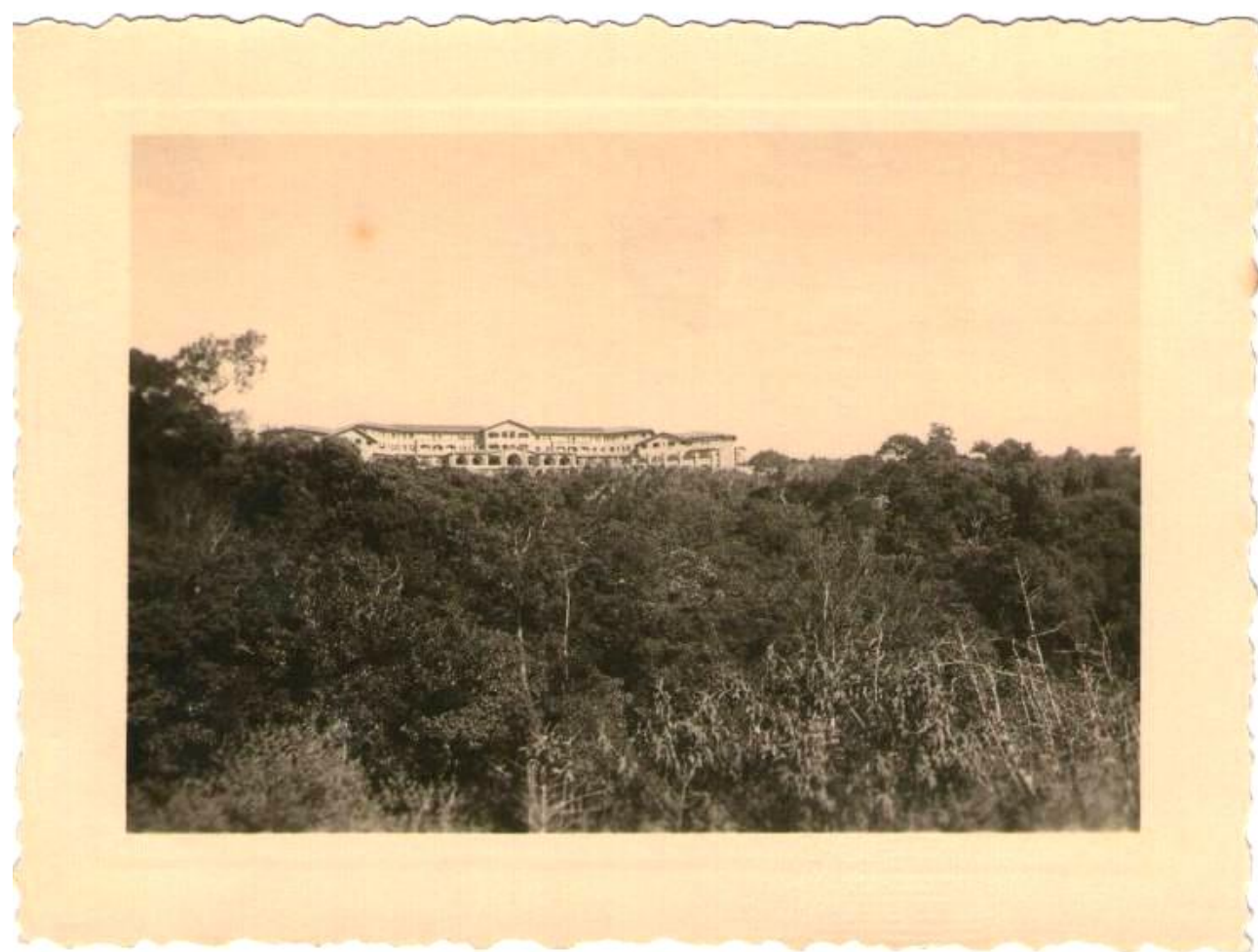

Foto 112: Grand Hotel em 1943. Ampliação das dimensões originais: 6 x 9 cm. Papel $A g f a$ Lupex.

Foi somente em 1938 que Adhemar de Barros ${ }^{122}$, então governador de São Paulo, assinou um decreto elevando Serra Negra à categoria de Estância Hidromineral e Climática. Esse feito ajudou a definir ainda mais o destino turístico desta localidade, que quatro anos depois inauguraria o Grand Hotel $^{123}$ (fotos 112, 113 e 114). Fundado apenas um ano antes da viagem de Cleonice e seus amigos e construído em estilo colonial $^{124}$, o estabelecimento parece ter sido o segundo local de hospedagem do grupo e, diferentemente do Rádio Hotel, encontrava-se em ambiente mais afastado do núcleo urbanizado.

Visto à distância, tendo em primeiro plano uma moldura composta de vegetação, a aparência da construção é imponente, como se o edifício que projeta-se ao fundo

\footnotetext{
122 (Adhemar Pereira de Barros, Piracicaba, 1901 - Paris, 1969).

${ }^{123}$ Atualmente o estabelecimento hoteleiro é conhecido como Biazi Grande Hotel.

${ }^{124}$ De acordo com o site: http://www.biazigrandhotel.com.br/o-hotel Acesso em 26/3/2012.
} 
estivesse protegido pela mata em primeiro plano, dificultando o acesso. Em relação às outras imagens que compõem a pequena série de quatro fotos, o registro 112 sugere desejo de aproximação.

A foto 113 realiza essa aproximação, porém revela um ambiente árido e descampado, bem diferente da área arborizada que atualmente o hotel ocupa ${ }^{125}$. Se comparado ao Rádio Hotel, falta ao Grand Hotel o calçamento da rua, tanto quanto não existem jardins e árvores como no primeiro. O registro fotográfico é seco, e a imagem resultante torna tudo bem homogêneo com pouco contraste entre os elementos da composição. As mulheres destacam-se por suas roupas escuras, enquanto que na figura da criança os tons são os mesmos da construção e do chão. O céu é liso, seja em decorrência das limitações da câmara amadora, seja porque não havia nuvens no momento da tomada. O grupo parece estar esperando a chegada da carroça que os levará para conhecer o entorno do Hotel erigido próximo à Serra da Mantiqueira.

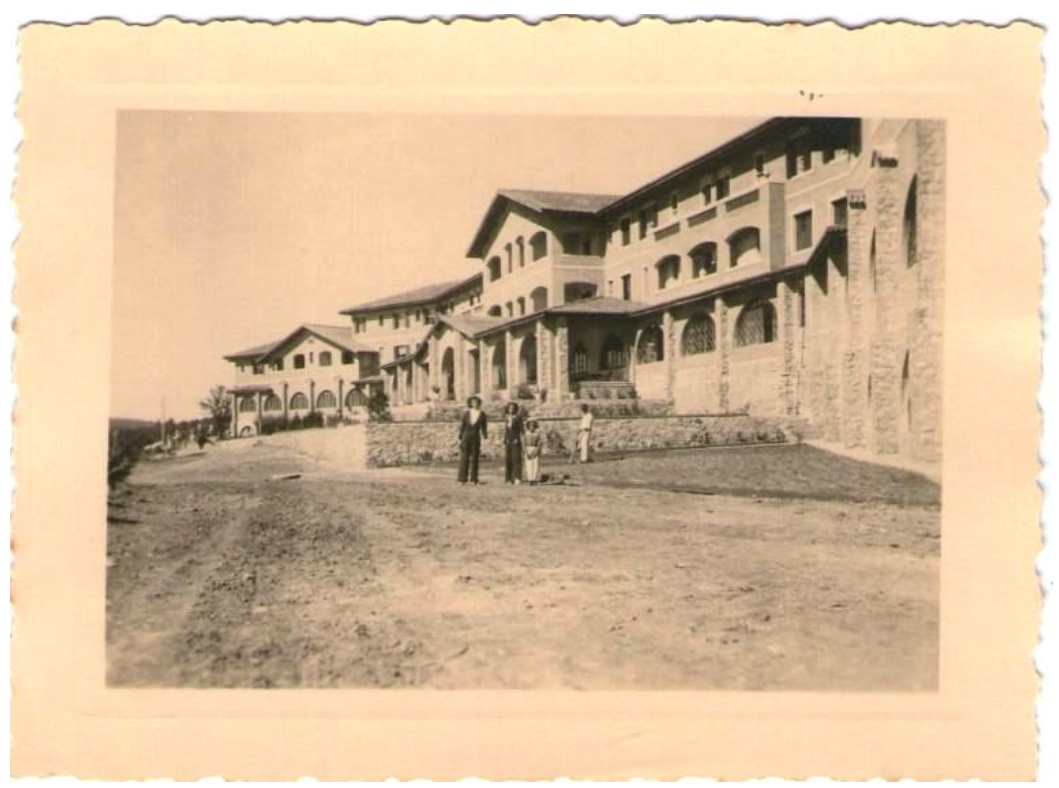

Foto 113: à direita de Dona Olga e Dircinha na frente do Grand Hotel. Ampliação das dimensões originais: 8,0 x 5,5 cm. Papel Agfa Lupex.

Eles saem para passear pelos arredores - é o que diz a foto 114. O fotógrafo apenas empresta seu olhar e fica anônimo, pois o gesto de tirar a foto é simples: basta olhar no visor e clique!. O interessante nessa série de fotos é que o hotel mantém-se na cena como uma referência importante, variando apenas a distância da tomada.

\footnotetext{
${ }^{125}$ Ver por exemplo as fotos disponíveis no site: http://www.biazigrandhotel.com.br/o-hotel. Acesso em $24 / 8 / 2012$.
} 


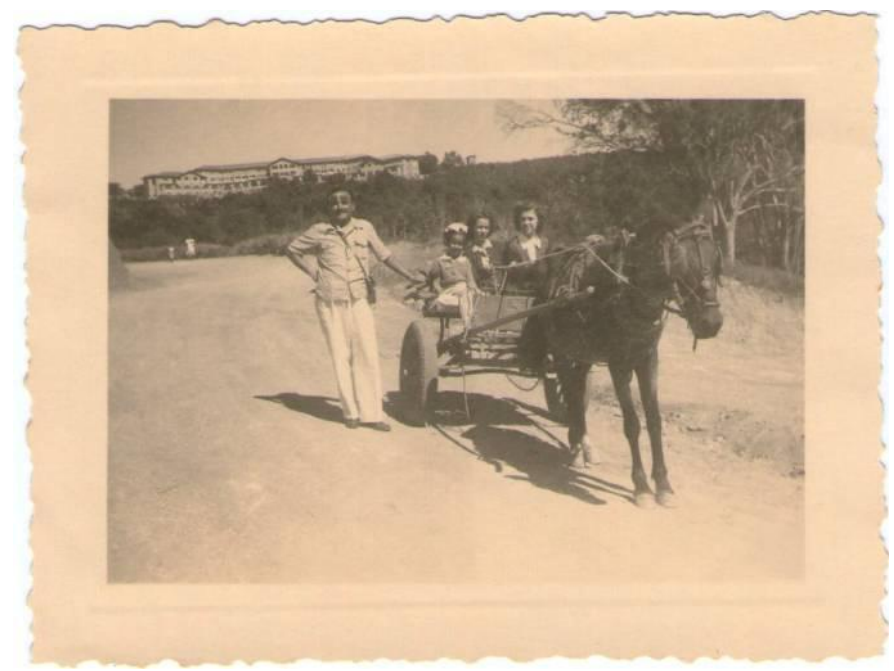

Foto 114: Cleonice e a família Souza passeiam nos arredores do Grand Hotel em Serra Negra. Dimensões: 6 x 9 cm. Papel Agfa Lupex.

O turismo ao campo preconizava o contato com a natureza, a mudança de ares, deslocamento em ruas de terra, algo talvez incomum para alguns habitantes da capital, que moravam em lugares urbanizados.

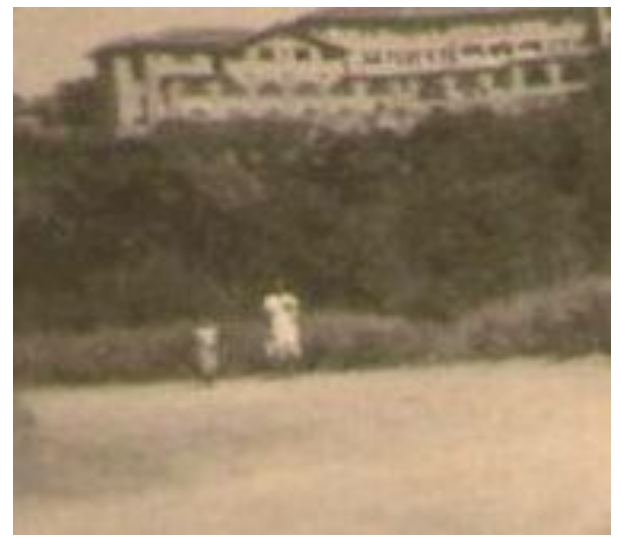

Detalhe 114a: Possíveis habitantes do lugar andam próximo ao Grand Hotel em 1943.

No detalhe 114a, aparecem uma mulher e uma criança, possivelmente moradores locais. A presença dessas pessoas lembra a forma como o turismo vai se estruturar na sociedade de consumo, quando aproxima visitantes e visitados. Na qualidade de turistas, Cleonice e os Souza chegam a esses destinos e acabam, em algum momento, estabelecendo contato com a população local. A presença dos moradores locais andando no caminho de terra contra o enorme hotel ao fundo assinala também as contradições do 
consumo turístico que gera espaços privilegiados, nos quais a população pobre local contrasta com a estrutura de hospedagens para os visitantes.

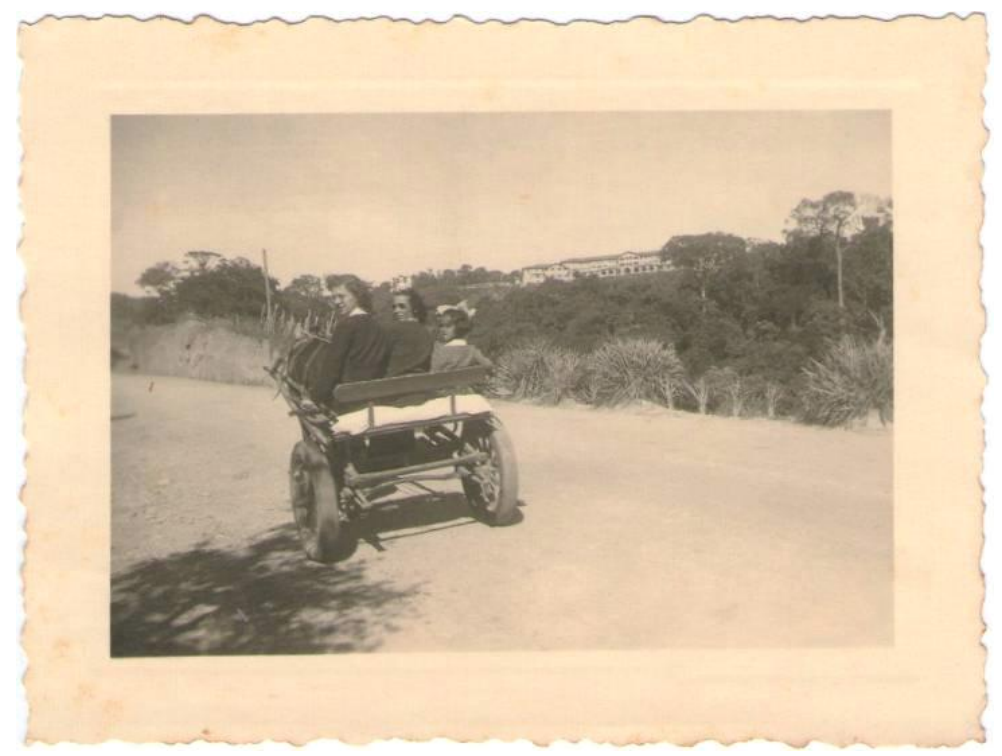

Foto 115: Volta do passeio, 1943. Dimensões: 6 x 9 cm. Papel Agfa Lupex.

Após o passeio aos arredores, o grupo retorna ao hotel (foto 115). Eles voltam ao conforto de um espaço partilhado, cujo interior não se mostra. Essa sociabilidade não é objeto de descrição visual, registra-se apenas o aspecto exterior: fachada perto ou distante, o caminho de ida e volta, a ausência e a presença do Sr. Souza. Mas nunca a vida que se desenrolava dentro do hotel. O que atrai o olhar fotográfico dos turistas é o aspecto exterior dos locais visitados, sua face pública.

Pode-se notar, entretanto, que o desinteresse pelos ambientes internos destas estruturas comerciais talvez reproduza, em alguma medida, a lógica das fotografias dos espaços domésticos: da mesma forma que não se fotografam quartos, banheiros e cozinhas, em razão do apelo íntimo que eles possuem, também certas áreas dos hotéis não podem ser registrados, quiçá por razões similares. 


\subsection{Passeio da Capela, Sítio Caruso e Cachoeirinha}

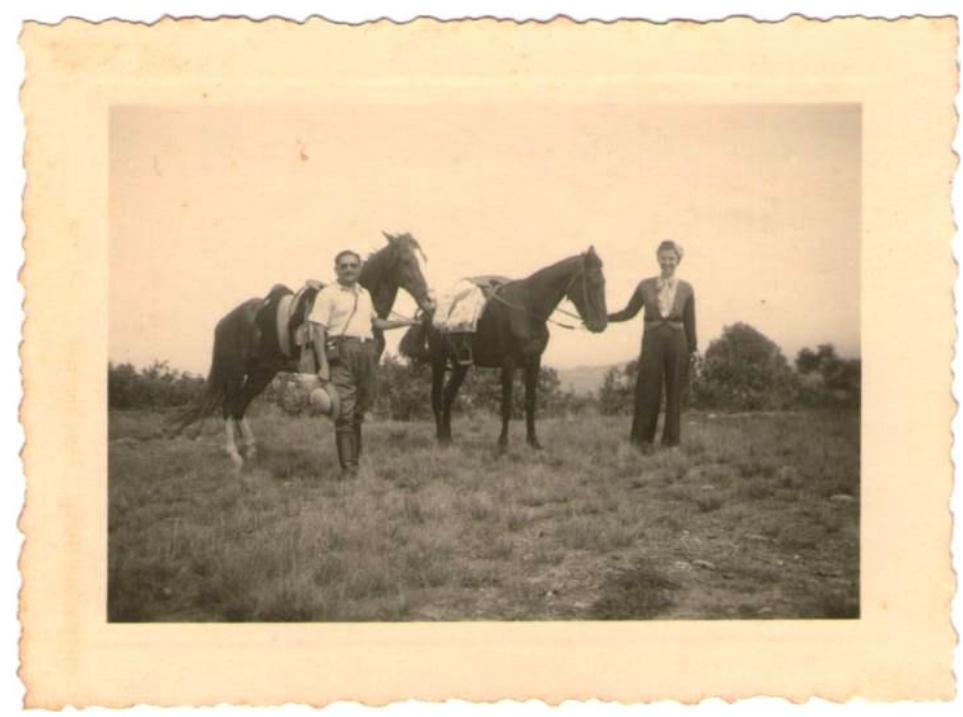

Foto 116: O Sr. Souza e Cleonice em Serra Negra, 1943. Dimensões: 6 x 9 cm. Papel Agfa Lupex.

A prática do turismo nas estâncias hidrominerais poderia ter sua origem em uma recomendação médica, que prescrevia temporadas de repouso e atividades físicas como caminhadas a pé e a cavalo. Na foto 116 , Cleonice e o Sr. Souza posaram diante de cavalos em cavalgada que feita com um grupo maior de pessoas. Se prescrita por médicos devia ser realizada com moderação e o objetivo, sobretudo a partir dos anos 1930, era "reabilitar o equilíbrio do corpo" (MARRICHI, 2011:15). Não se pode afirmar que Cleonice e o Sr. Souza a realizaram devido a esta orientação. Supõe-se, todavia, que práticas como caminhadas, passeios de charrete, cavalgadas e contemplação da natureza estavam presentes no imaginário desses destinos turísticos: eram formas de adquirir ou manter a saúde do corpo e do espírito ${ }^{126}$.

Nesse passeio (foto 116), eles puderam circular pelo ambiente natural serranegrense: "altitude média de 983 metros, incrustada entre verdejantes montanhas" e "excelentes originalidades de paisagens" ${ }^{127}$. As fotografias que identificam esse roteiro cavalgado foram legendadas como "passeio da Capela", cuja construção aparece na foto

\footnotetext{
${ }^{126}$ Cleonice gostava, como já visto, de praticar esportes nos anos 1930. Ver fotos 21, 22, 23, 24 e 25 no capítulo 1

${ }^{127}$ Revista do Comerciário n.18, novembro-dezembro, 1957, pp.4-6. Acervo GEDES SESC Memórias.
} 
117 abaixo.

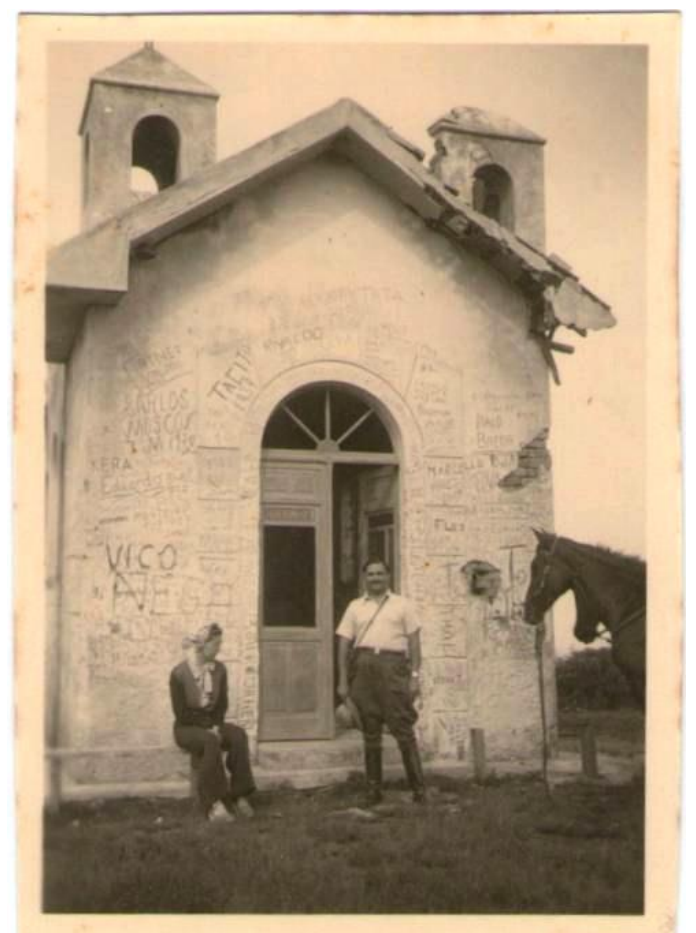

Foto 117: Cleonice e o Sr. Souza posam na frente de uma Capela degradada. Ampliação das dimensões originais: 6 x 9 cm. Papel Agfa Lupex.

É interessante notar que, embora a capela esteja um tanto arruinada, ela não foi identificada como "ruína", como o foram as fotos 64 e 83 do litoral. Essa identificação pode esclarecer os diferentes sentidos que essas construções assumiam nas paisagens conhecidas por Cleonice e seu grupo. Basta compararmos a foto desta igrejinha com aquelas duas no litoral, onde a grandiosidade das ruínas assinala a importância das referidas cidades de Itanhaém e Bertioga. Quanto a simplicidade arquitetônica, esta capela assemelha-se mais a pequena igreja construída na Colônia Ruy Fonseca (foto 76), guardando, porém, enorme diferença quanto ao uso de uma e de outra. Na imagem 117, a igrejinha perdeu seu uso original e tornou-se de fato uma ruína, monumento que lembra ações passadas. No SESC a construção da capela objetivava fortalecer a vontade espiritual dos turistas. Aqui os restos da pequena construção são também o resíduo de interações sociais e, ao observar a parede (detalhe 117a), nota-se que foi suporte de expressão de individualidades desconhecidas ${ }^{128}$.

\footnotetext{
${ }^{128}$ Alain Corbin nota a difusão do hábito de as pessoas marcarem seus nomes em "árvores e rochas com fins privados no século XIX na França". Para o autor o fato está ligado, de alguma forma, aos progressos da alfabetização e dos vínculos até então inéditos entre o indivíduo, seu prenome e seu sobrenome. O autor lembra que se trata de uma "prática dos humildes; conscientes de que, distintamente dos poderosos,
} 


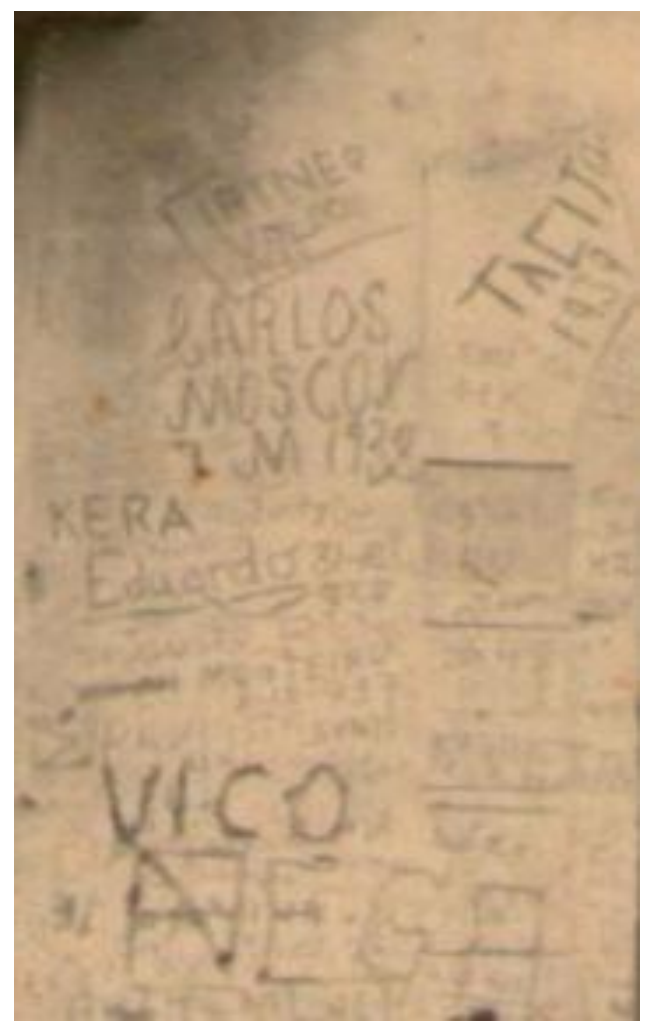

Detalhe 117a

São pessoas que ali estiveram antes de Cleonice: "Carlos Mosco, M 1938, Tacito 1939, Kera, Eduardo, Vico, Irineo, Nega" e outros que, ao deixarem seus nomes na parede da construção, ajudaram a definir o próprio lugar com sua mobilidade pedestre, o que mostra que a capela depredada tinha importância como ponto de visitação. Nas deambulações de Cleonice, figuram nomes de lugares que lembram pessoas importantes para a constituição do turismo de recreação e lazer serra-grandense. É o caso do Sítio Caruso $^{129}$, criado pelo agricultor italiano Caetano Caruso ${ }^{130}$. Deste local foram guardadas três fotografias, duas mostradas aqui.

não deixarão marcas, eles contam com a perenidade de suas iniciais gravadas nos troncos ou na pedra". (CORBIN, 1999: 420-421).

${ }^{129}$ Atualmente, conhecido como Recanto Caruso.

${ }^{130}$ Caetano Caruso (1875-1959), nascido em Basco na Itália. Na década de 1940 conta-se que ele abriu o Sítio Caruso para a população de Serra Negra e para os turistas que para lá iam. O sítio oferecia várias atrações como navegação pelo lago, árvores frutíferas, 'matinées' e 'soirées' dançantes. Possuía restaurante que servia comida italiana. No fim da década de 1950 o Recreio Caruso desapareceu. Conta-se que seu fundador foi um dos precursores do turismo na cidade. Jornal de Serra Negra, 7 de janeiro de 2005. Agradeço a José Roberto Franco da Rocha, que gentilmente me cedeu informações sobre o sítio. 


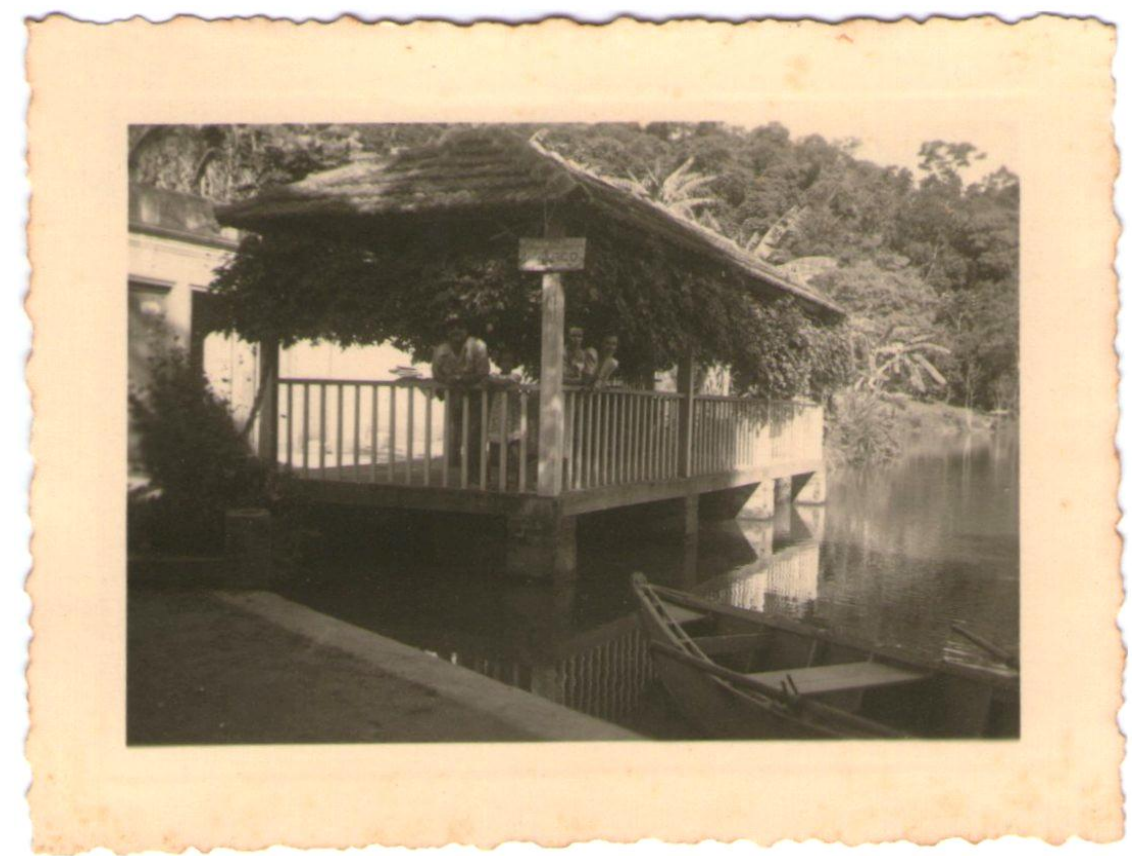

Foto 118: Cleonice e a família Souza no Sítio Caruso, Serra Negra nas férias de 1943. Ampliação das dimensões originais: 6 x 9cm. Papel Agfa Lupex.

A foto 118, feita por anônimo, exibe o grupo sobre o lago navegável, uma das atrações do sítio. Se navegaram, não é possível saber, porém na foto 119 Cleonice, Dona Olga e Dircinha parecem apenas esperar que o Sr. Souza se junte a elas para passearem no lago. Pelas embarcações disponíveis o passeio devia ser procurado com frequência pelos turistas. Os barcos permitiam aproximação com a mata que aparece ladeando o lago. A vegetação era composta de árvores como "amoreiras silvestres, samambaias e outras folhagens exóticas" 131.

\footnotetext{
${ }^{131}$ Jornal de Serra Negra, 7 de janeiro de 2005.
} 


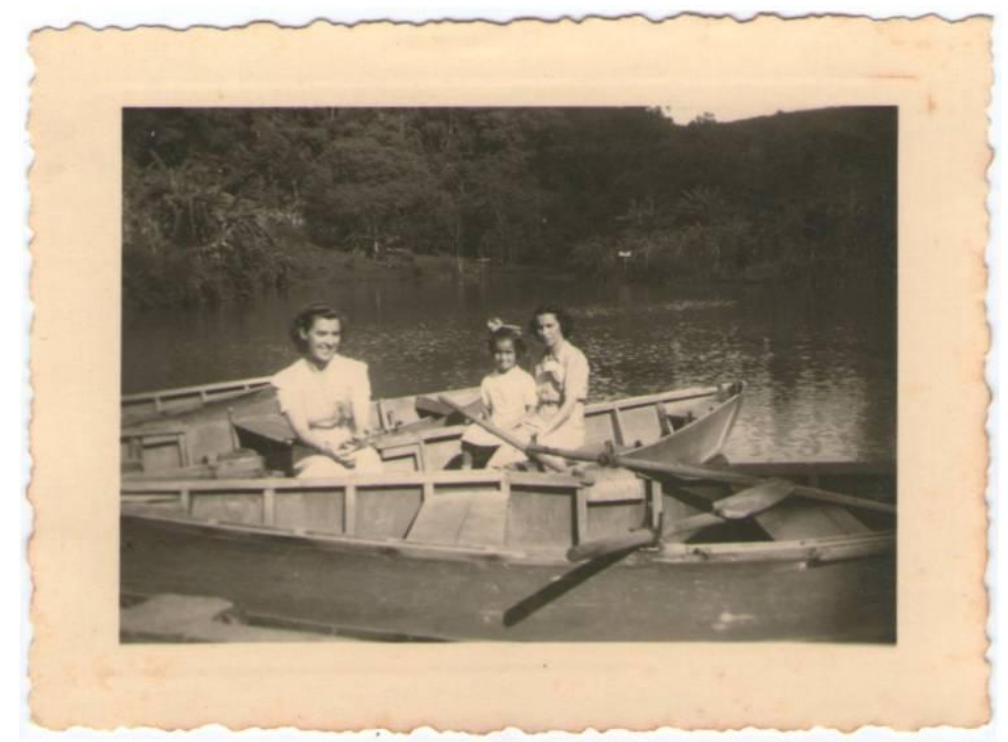

Foto 119: Cleonice, Dircinha e dona Olga no lago do Sítio Caruso nas férias de 1943. Ampliação das dimensões originais: 6 x 9 cm. Papel Agfa Lupex.

È interessante observar que, embora acompanhada pela família Souza, ora completa, ora apenas com o Sr. Souza, Cleonice encontra maneiras de ser fotografada sozinha, como nas fotos intituladas: "Caminho à Cachoeira Grande" (foto 120) e "Cachoeira Grande" (foto 121).

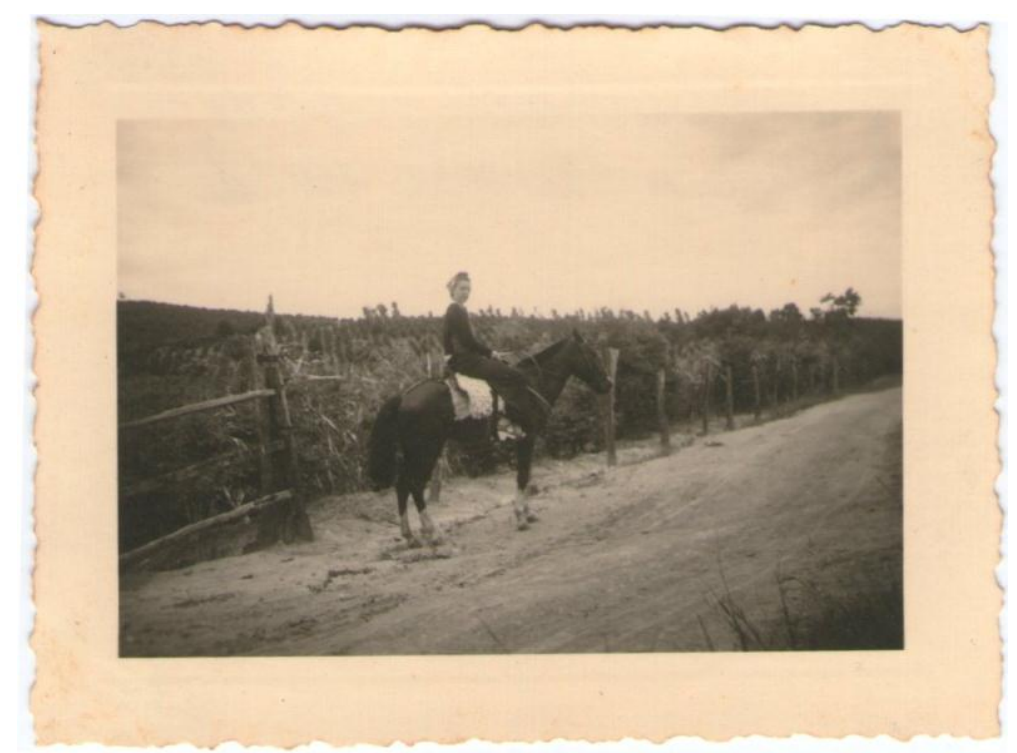

Foto 120: Cleonice no caminho para a cachoeira grande. Serra Negra, 1943. Ampliação das dimensões originais: 6 × 9 cm. Papel Agfa Lupex. 
Na primeira imagem, ela dirige-se à cachoeira. Ao passo que na foto 121 ela chega ao local onde fica a cachoeira, porém, não há qualquer indício de água.

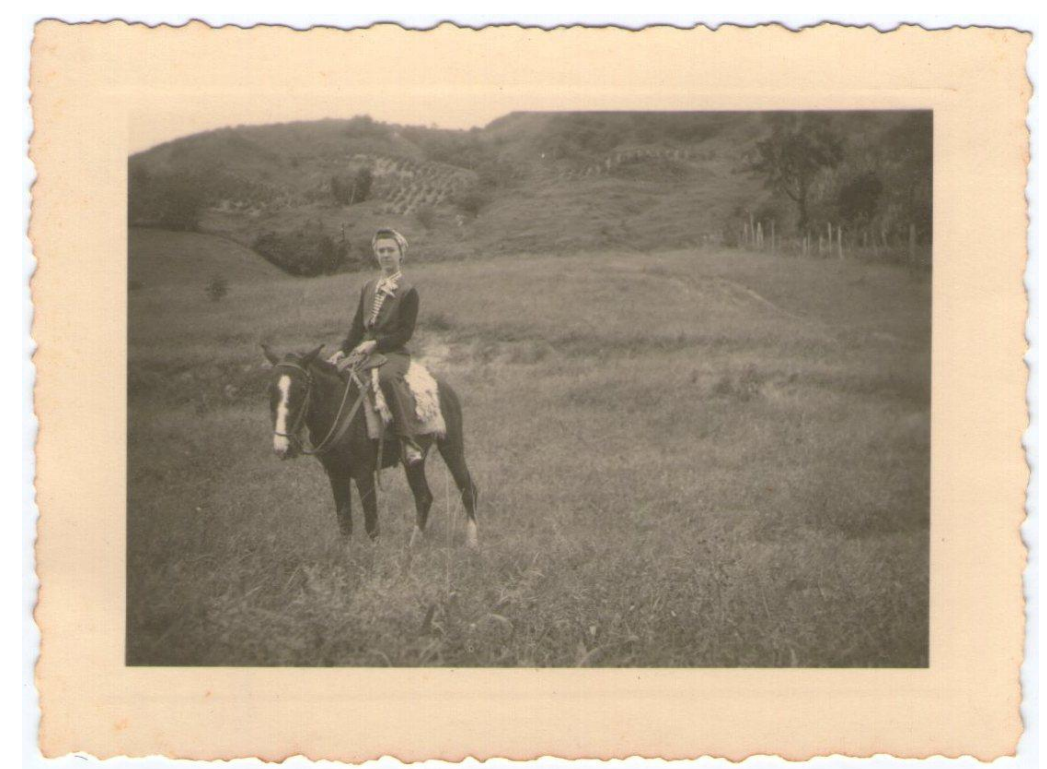

Foto 131: Cleonice no caminho para a cachoeira grande. Serra Negra, 1943. Ampliação das dimensões originais: 6 × 9 cm. Papel Agfa Lupex.

A distância em relação à água no período de férias em que o grupo esteve em Lindoia e Serra Negra é bastante significativa, caso consideremos que eles estavam em cidades onde a água era um elemento natural explorado por empresários como uma resposta à crise trazida pela economia cafeeira. Embora Cleonice e a família Souza apareçam muito próximas às águas (fotos 101,110, 118 e 119,) em nenhuma ocasião há contato direto com o líquido, ao contrário do que se verificou no litoral.

A imagem 122 exibe o grupo na "Cachoeirinha", cuja suposta pequena dimensão fornecida pelo nome deste lugar poderia ser uma comparação com a "Cachoeira Grande”. Nesta foto o Sr. Souza destaca-se desbravador, de pé, com seu traje turístico e sua câmara momentaneamente emprestada a quem pudesse dar o clique. 


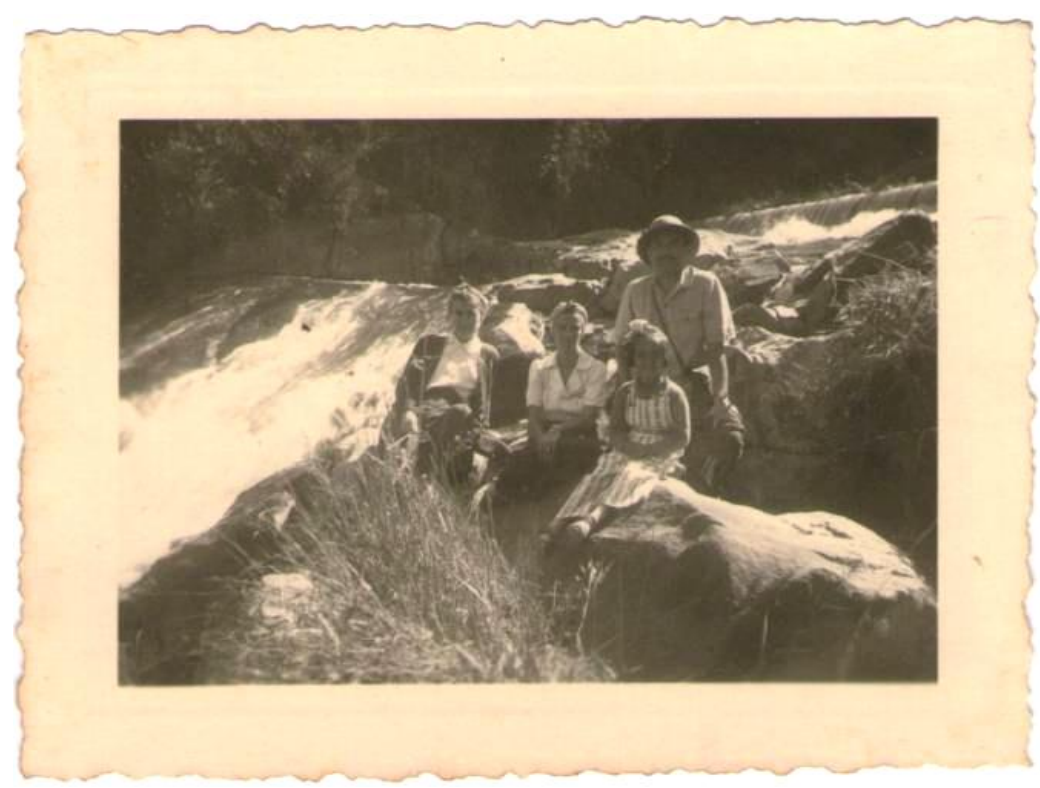

Foto 122: Cleonice à extrema esquerda com a família Souza, Serra Negra, 1943. Ampliação das dimensões originais: 6 x $9 \mathrm{~cm}$. Papel Agfa Lupex.

Embora o período de férias em Lindoia e Serra Negra pareça ter dado lugar a uma viagem quase "sem água", é possível que o grupo tenha experimentado os benefícios das águas termais, características destas cidades, e até mesmo seguido dietas baseadas em leite e carne. Afinal, as terapias hidrominerais ainda gozavam de prestígio durante os anos 1940. Foi na década seguinte que o termalismo clínico no Brasil começou a perder força, o que já acontecera, por exemplo, em Portugal um pouco antes (QUINTELLA, 2004a). Contudo o turismo de diversão assumiu melhor posição em relação tanto à crença religiosa inicial quanto às suas capacidades curativas científicas. Ocorrerá algo semelhante em Campos do Jordão, quando uma decisão do governo do estado dividirá a cidade em duas zonas: uma de curismo e outra de turismo. 


\title{
3.5. Campos do Jordão: entre serras e araucárias
}

\author{
O clima é em geral seco e frio na maior parte \\ do ano, e a temperatura chega frequentemente a \\ zero grau centígrados no inverno. A vegetação \\ predominante é de florestas de araucária \\ entremeadas por campos de altitude nos topos \\ de morros (SILVA, 2003: 85).
}

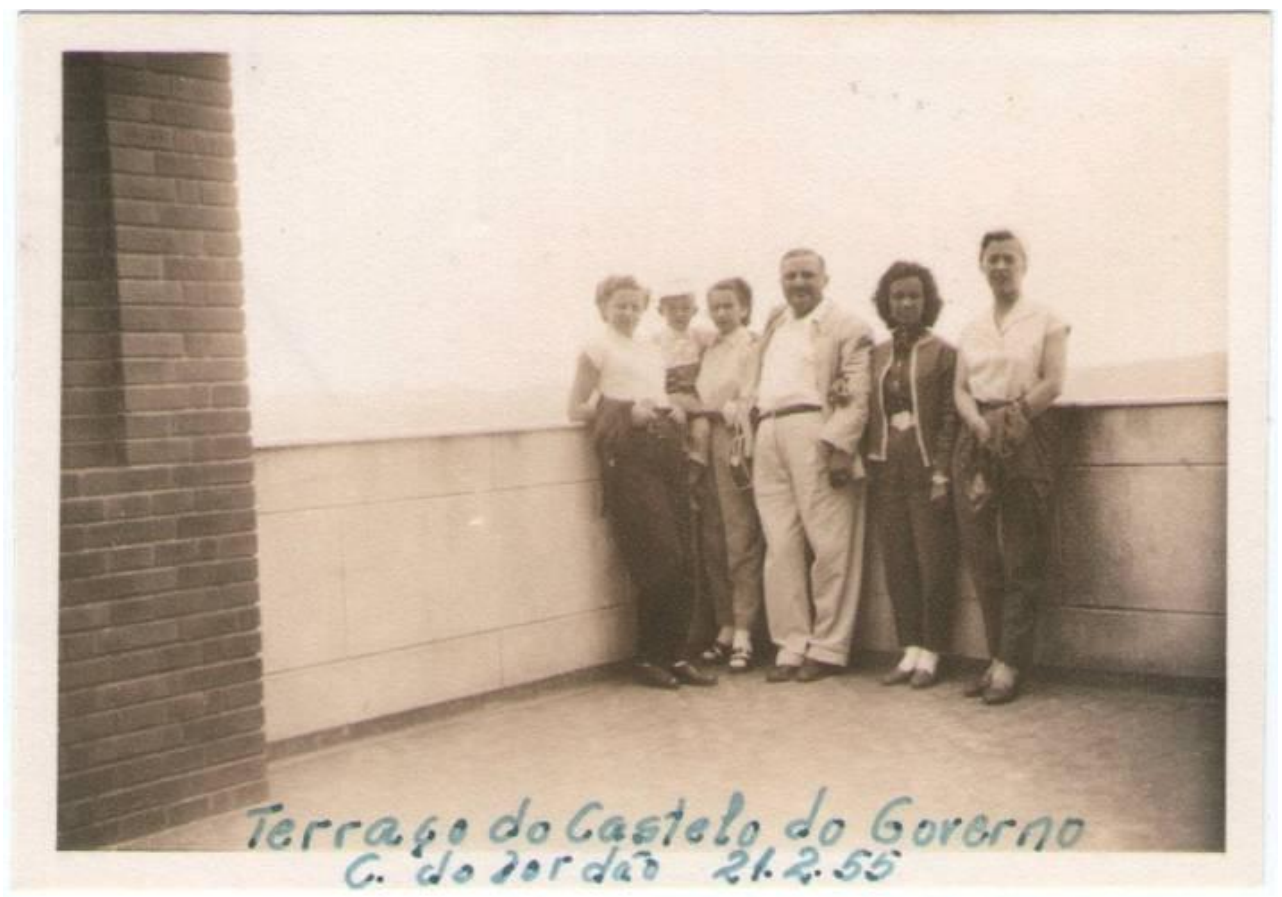

Foto 123: Cleonice, à direita, sua prima Érika, à extrema esquerda e a família Souza. Ampliação das dimensões originais: 6 x $9 \mathrm{~cm}$. Papel Leonar.

Entre os dias 13 e 26/2/1955 Cleonice, sua prima Érika e a família Souza, agora com mais um filho, vão a Campos do Jordão. Na foto 123, o grupo está no ainda inconcluso "Castelo do Governo", obra iniciada na gestão do governador Adhemar de Barros. O Palácio Boa Vista, como será conhecido mais tarde, era a residência de veraneio do governador, e foi finalizado somente em 1964, quando da terceira gestão de Barros no governo do Estado. Pelo que informa a foto, a obra já estava aberta à visitação.

Embora o conteúdo da imagem nada revele da paisagem montanhosa no entorno do castelo, a aproximação entre esta e outra foto da série de vinte e seis imagens mostra 
o ambiente natural onde a construção foi instalada.

A foto 124 exibe a estrada que levava ao castelo e, por meio dos elementos naturais que nela aparecem, tem-se uma ideia do que eles viram quando estiveram no terraço. Há duas possibilidades de entender o que está informado na legenda "Estrada p. Castelo do Governo": 1) O grupo ainda não havia chegado ao castelo, que talvez esteja atrás do conjunto de morros 2) A vista da estrada foi tomada justamente do terraço onde eles aparecem.

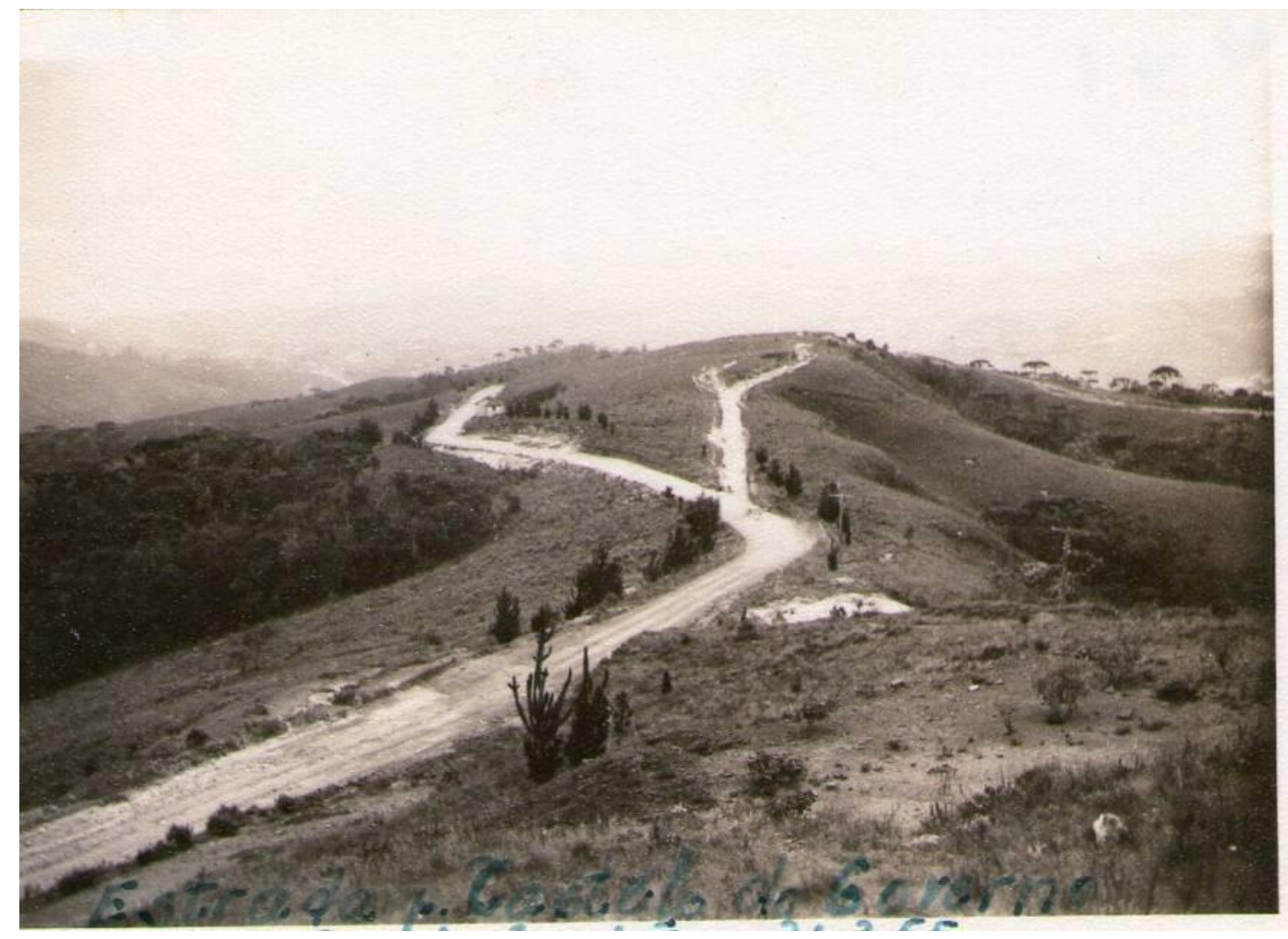

Foto 124: "Estrada para o Castelo do Governador" (Legenda original), 1955. Ampliação das dimensões originais: 6 x $9 \mathrm{~cm}$. Papel Leonar.

Do mesmo modo que Serra Negra e Lindoia, Campos do Jordão era uma cidade voltada para a saúde e combinava elementos naturais importantes, que vinham sendo valorizados por médicos e doentes e, mais tarde por aqueles que podiam consumir suas paisagens, como forma de diversão. Como disse em tom elogioso, em 1957, o editor da Revista do Comerciário:

Felizes aqueles que tiveram a ventura de admirar a imensidão e diversidade de panoramas, de transportar para os olhos o espetáculo maravilhoso que 
oferece a natureza numa movimentação de curvas, rendilhados, altos e baixos relevos, a contar-nos sua beleza e engenho do criador! Isso é Campos do Jordão! ${ }^{132}$

Localizada na Serra da Mantiqueira, em um dos pontos mais altos e frios do país, está atualmente entre os municípios de maior rede hoteleira do Brasil. Como muitas outras cidades litorâneas e serranas, Campos surge do investimento do capital paulista no século XX (SILVA, 2003: 11-12). Sua vocação balneária remonta ao início desse século a partir de um modismo que começou na Europa ainda no século XVIII que concebia os lugares altos e mais frios, bem como determinadas águas, como capazes de garantir saúde por meio de processos terapêuticos adequados aos doentes crônicos, em especial os do aparelho respiratório, como asmáticos e tuberculosos, que buscavam tratamento para as moléstias pulmonares.

Nesta cidade, o binômio curativo/turístico se repete como em Serra Negra e Lindoia, mas trata-se de vocação diversa: lá, voltada aos reumáticos e àqueles que tinham problemas de pele; aqui, aos portadores de doenças do pulmão. Maria da Gloria Lanci da Silva afirma que Campos do Jordão é "incomum entre as paisagens brasileiras", pois, na composição de seu cenário, comparecem elementos como: baixas temperaturas, relevo montanhoso, florestas de pinheiros e construções imitando chalés alpinos (2003:90). No período em que Cleonice ali esteve, o local ainda não possuía essa última característica, como algo distintivo da cenografia turística, embora ela tenha visitado um hotel de nome "Refúgio Alpino" (fotos 128,129 e 130).

A estação ferroviária chega à cidade pelas mãos do famoso médico higienista e sanitarista Emilio Ribas (1862-1925) e pelo também médico sanitarista Victor Godinho (1862-1922). O objetivo do empreendimento era facilitar o transporte de tuberculosos à cidade para tratamento médico. Em 1911, os médicos "haviam iniciado projeto de uma vila sanitária na antiga Fazenda Capivary" (idem, 152). A estação, que ligava Campos do Jordão ao Vale do Paraíba, começou a ser construída em 1912, vinte anos depois de Serra Negra. Só em 1915 a linha férrea foi entregue ao tráfego na gestão do presidente do estado de São Paulo, Rodrigues Alves (1912-1916). A Lei nº 2140 de 1º/10/1926 que a transformou em estância e "prefeitura sanitária" ligada, porém, à comarca de São José dos Campos. Em 1934, foi elevada à categoria de município e, em setembro de 1935 , Prestes Maia foi o responsável pelo primeiro estudo urbanístico junto à Comissão de

\footnotetext{
${ }^{132}$ Revista do Comerciário, n. 18 nov/dez. de 1957. Acervo GEDES SESC Memórias.
} 
Estudos sobre a Urbanização da cidade ${ }^{133}$.

Entre 1937 e 1940, Adhemar de Barros propõe o primeiro zoneamento da cidade, dividindo a área urbana em zona sanatorial e zona turística ${ }^{134}$. Tal estratégia visava proteger os turistas (que elevavam extraordinariamente o custo de vida na cidade) do contato com os enfermos. Nos grandes hotéis, havia uma sala de raios $\mathrm{X}$ para que doentes não se hospedassem. A tensão entre doença e turismo foi claramente expressa pelo tom ressentido de uma das informantes do pesquisador Oracy Nogueira que estudou, na década de 40, o comportamento dos tuberculosos que para lá acorriam: "Êsses sãos têm o mundo todo para passear. Nós somente podemos viver nêste pedacinho de terra. No entanto, eles vêm justamente aquí para nos fazer concorrência e nos causar dificuldade!" (NOGUEIRA, 1950: 37).

A cidade em 1955 já oferecia diferentes roteiros recreativos (figura 11) e o curismo tornara-se uma atividade do passado. Com a descoberta do medicamento Hidrazida, a tuberculose passou a representar perigo menor, e a cidade começou a transformar-se em importante polo turístico, desvinculando-se da doença.

\footnotetext{
${ }^{133} \mathrm{Cf}$. dados disponíveis em: http://www2.uol.com.br/jornaldecampos/507/diretor.htm Acesso em 30/3/2012.

134 “A história de Campos do Jordão tem vários pontos de intersecção com a história do planejamento urbano no Brasil. Primeiro, porque desde sua fundação a cidade foi objeto de planos e projetos de caráter planificador, ou seja, que efetivamente desenhavam o aspecto urbanístico que a cidade deveria tomar. Segundo, pelo fato da frequente aproximação do poder executivo do Estado de São Paulo com as autoridades locais no sentido de participar e mesmo atuar neste processo de elaboração dos projetos que visavam o desenvolvimento urbano e econômico do município" (SILVA, 2003: 144).
} 


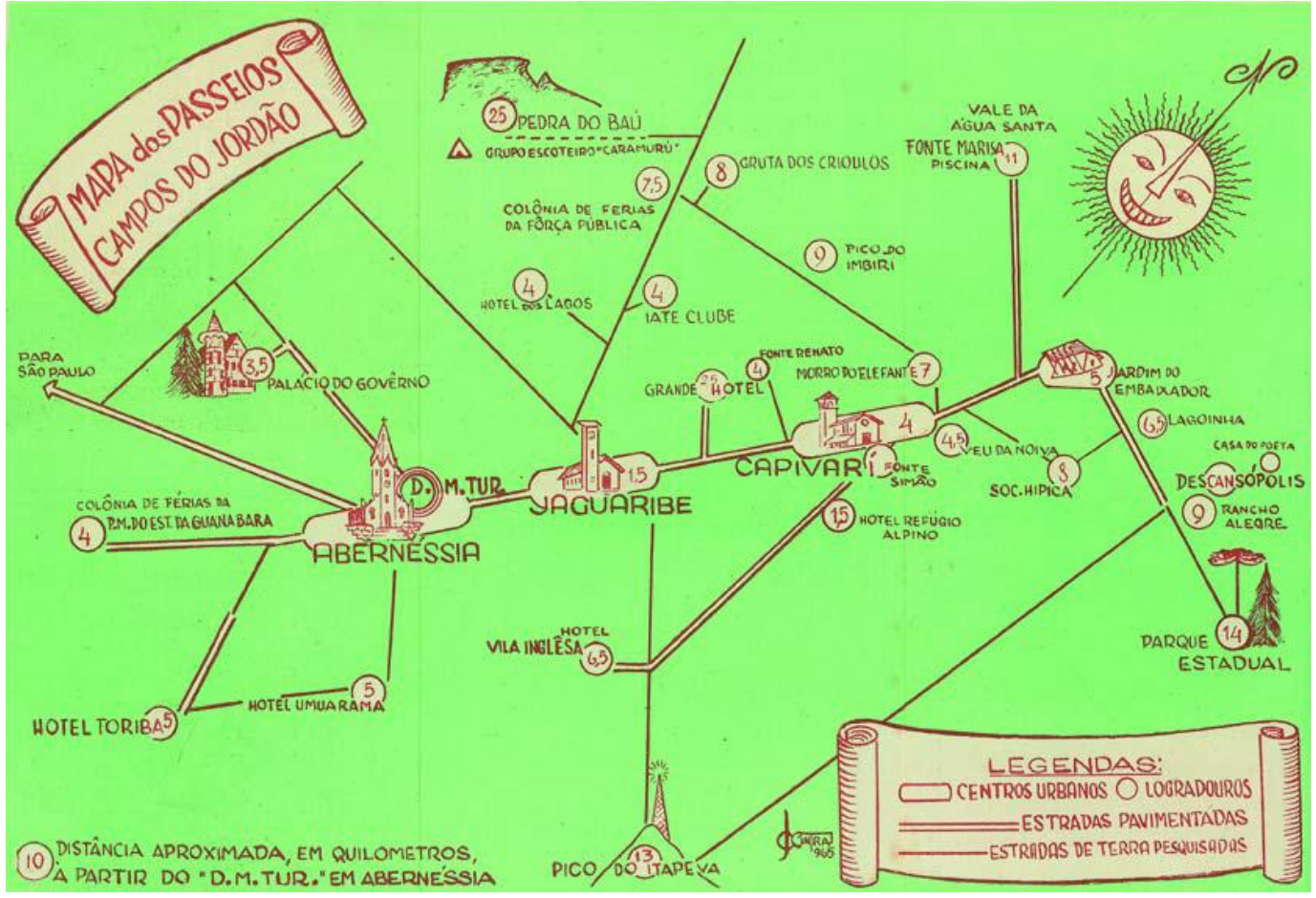

Figura 11: Mapa turístico de Campos do Jordão (verso),

publicado entre as décadas de 1950 e 1960. Fonte: SVEVO e NEDOPETALSKI, 2007: 36.

A figura 11 exibe o "Mapa dos passeios", no qual aparecem vários dos pontos que Nelli e a família Velloso conheceram: os hotéis Toriba, Refúgio Alpino, Umuarama, Hotel dos Lagos (segundo a legenda de Cleonice: "Terraço dos lagos"); o Pico do Itapeva, o Palácio do Governo e o Morro do Elefante. O grupo visitou ainda outros lugares que não aparecem no mapa, como a Represa da Usina de Campos do Jordão. 


\subsection{Os hotéis Toriba, Refúgio Alpino e Umuarama: o incremento do turismo}

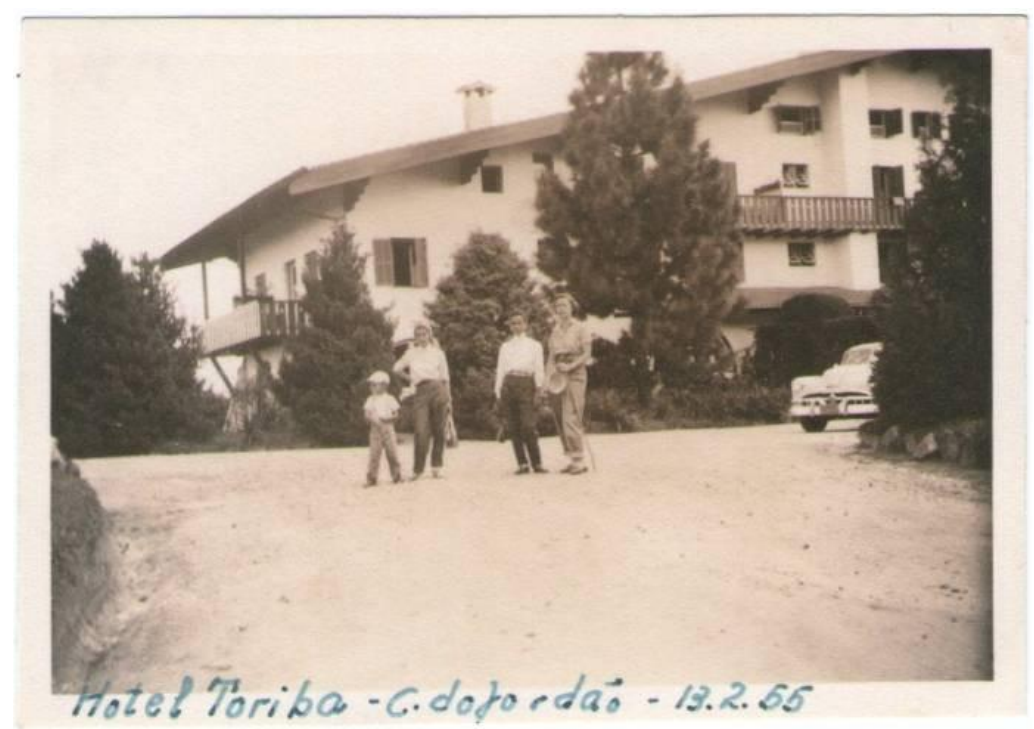

Foto 125: Cleonice com parte da família Souza no Hotel Toriba,

Campos do Jordão 1955. Ampliação das dimensões originais: 6 x 9 cm.

Papel Leonar.

$\mathrm{Na}$ foto 125 , Cleonice e parte da família Souza aparecem diante da fachada do Hotel Toriba ${ }^{135}$ no primeiro dia de hospedagem. Pela posição do grupo no espaço, podese dizer que estão se preparando para sair e descerão a rua encontrando o fotógrafo (que estava mais abaixo) para passearem. Deste dia, restaram apenas duas fotos na coleção: esta acima e outra não exibida aqui, na qual eles aparecem na "Represa da Usina de Campos do Jordão". Há um vazio visual entre os dias 14 e 18, de modo que as outras imagens cobrem apenas a última semana de passeios entre os dias 20 e 26.

O surgimento do Hotel Toriba em 1943, cujo idealizador e proprietário foi Ernesto Diederichsen (1877-1949), assinala as transformações que a cidade começava a experimentar a partir da separação espacial entre a zona de tratamento de doentes e a de turismo. A construção com telhado de duas águas foi inspirada na arquitetura dos Alpes Suíços, traço que, com o passar dos anos influenciará o estilo arquitetônico

135 Segundo Maria da Glória Lanci da Silva "o mais importante alojamento de luxo em funcionamento nesta cidade até 2003" (Cf. SILVA 2003:154). O hotel foi construído pelo escritório técnico Ramos de Azevedo, Severo e Villares e Cia. Ltda, sob responsabilidade dos engenheiros Affonso Lervolino e Roberto Batista Pereira de Almeida, no de 1941 (Cf. SVEVO e NEDOPETALSKI, 2007:36). 
predominante na cidade. $\mathrm{O}$ estabelecimento surgira com o objetivo de acolher pessoas interessadas em "cavalgadas, longas caminhadas, banhos de cachoeira, alpinismo, trilhas de bicicleta e piqueniques (SVEVO e NEDOPETALSKI, 2007:13). A imagem 125 mostra pouco da aparência do hotel; o fotógrafo capta apenas uma parte do edifício que funciona aqui como fundo cenográfico para enquadrar o grupo que o acompanha. $\mathrm{O}$ rico ambiente ecológico da serra que circunda o hotel tampouco aparece.

Ao compararmos esse registro com uma ilustração de adesivo para mala de viagem fornecido pelo hotel Toriba (figura 12), notam-se as diferentes formas de representar um mesmo motivo. Na ilustração comparecem os elementos evocativos da natureza singular de Campos: rica vegetação, araucárias e montanhas. A foto, por sua própria natureza, faz o corte, enquanto a ilustração reúne e aproxima os elementos, fornecendo uma vista em perspectiva panorâmica do hotel revelando o conjunto com a Pedra do Baú ao fundo. Na figura há um forte apelo ao aspecto pictórico e artístico do ambiente natural no qual foi instalado o Toriba. A paleta de pintura sugere que o lugar era tão bonito quanto um quadro pintado, ou que pudesse inspirar os artistas.

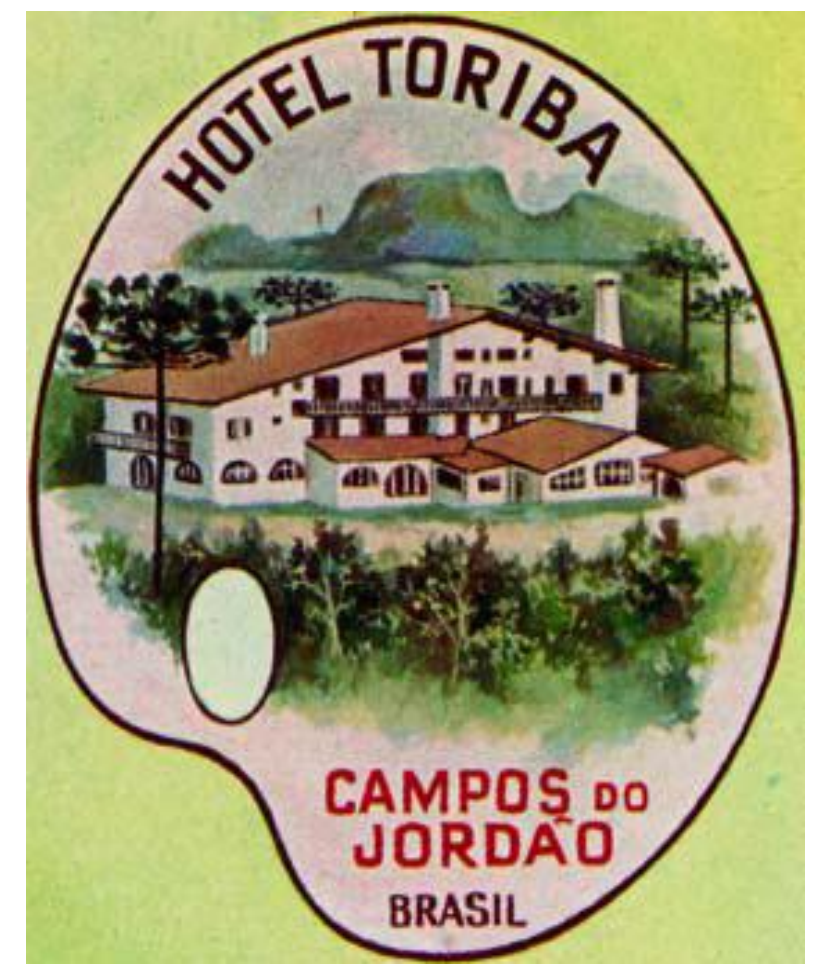

Figura 12: Adesivo para mala de viagem, década de 1940 e 1950.

Fonte: SVEVO e NEDOPETALSKI, 2007:36. 
Enquanto no adesivo de mala o Toriba é visto à distância, como lugar ideal, um refúgio tranquilo sem interações humanas, na foto 125 a presença do carro indica que a comunicação via transporte rodoviário entre a capital e Campos começava a intensificar-se. Contudo, nesse momento chegava-se ali de trem, carro ou ônibus. Estes dois últimos veículos acentuam uma tendência de valorização do transporte rodoviário, que também se verificou na capital paulista e no litoral. A empresa "Expresso Zefir", localizada no centro da Vila Capivari, fazia a ligação São Paulo-Campos do Jordão.

Na foto 126, "Despedida da Erika", a jovem de saia que está de pé no limite entre a guia e a rua preparava-se para voltar à capital. É de se notar a movimentação de homens na frente da rodoviária, muitos dos quais parecem aguardar a partida do ônibus. A presença das três mulheres e uma criança quebra essa predominância.

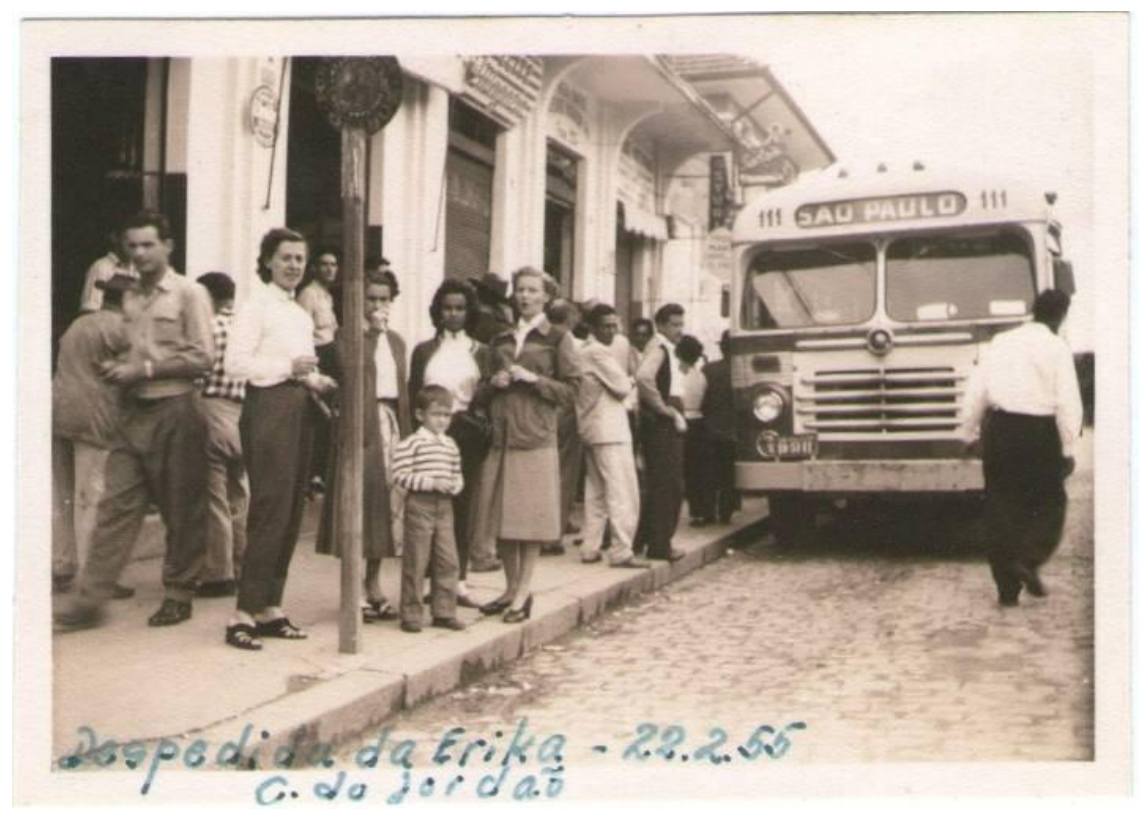

Foto 126: Cleonice, de camisa branca, Dona Olga, Dircinha e Erika, no dia de sua despedida em 22.5.55.

Embora a ligação rodoviária entre Campos e a capital paulista fosse possível desde a década de 1940, a localidade era ainda uma cidadezinha calma e tranquila, e o lazer dos que para lá acorriam baseava-se em passeios pelas redondezas, explorando trilhas, fruindo a natureza quase intocada (SVEVO \& NEDOPETALSKI, 2007).

Todavia, dois dias antes dessa foto da despedida, o Sr. Souza fizera uma tomada a partir do Hotel Toriba (foto 127), diferente da imagem 125, próxima demais da construção o que termina por omitir muito das dimensões e mesmo a beleza ecológica 
do terreno do edifício ${ }^{136}$. Não fosse a legenda nessa foto, seria impossível entender qual o tema do registro.

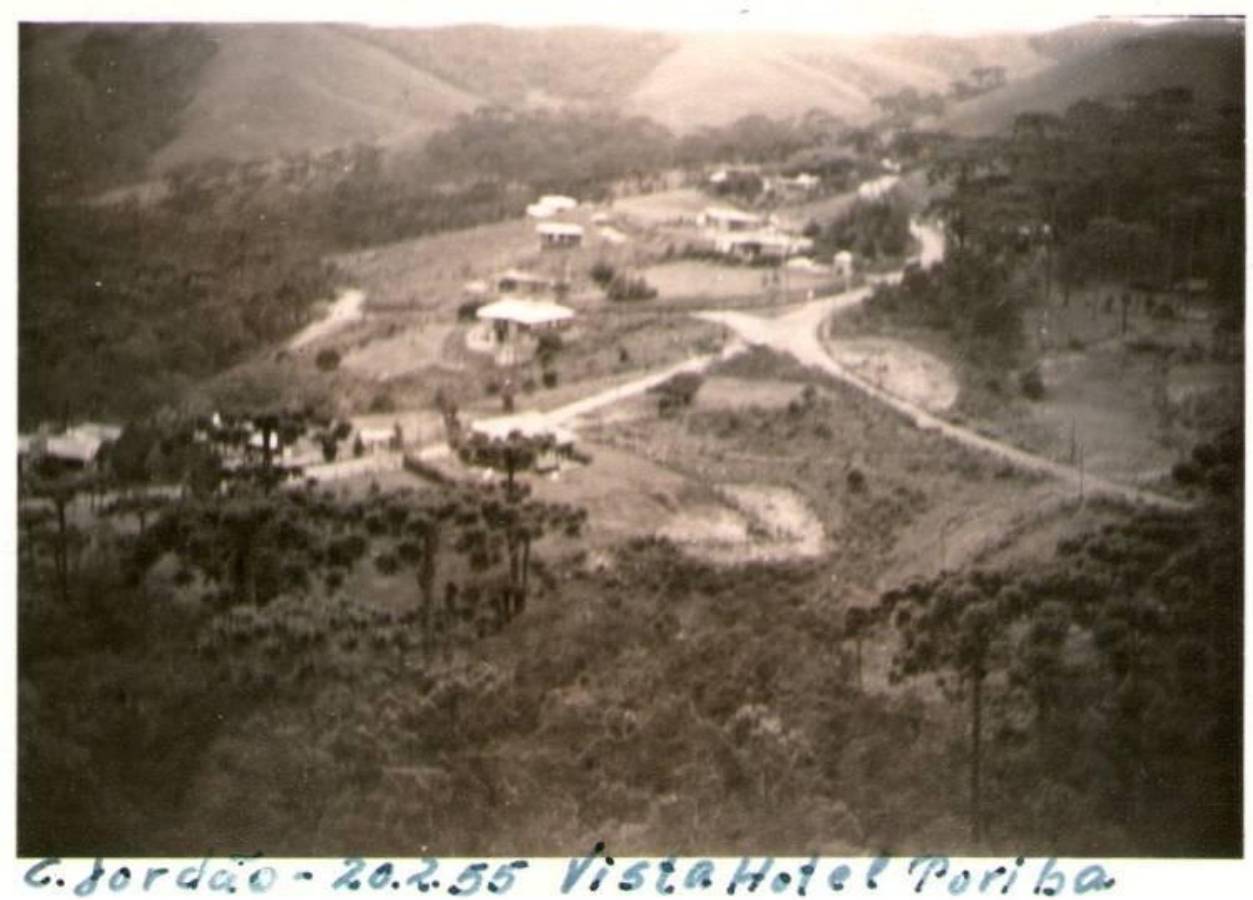

Foto 127: Vista do Hotel Toriba, Campos do Jordão, 1955. Ampliação das dimensões originais: 8,5 x 6 cm. Papel Leonar.

A influência do estilo alpino do Toriba se fez sentir em outro hotel, o Refúgio Alpino $^{137}$, idealizado e construído pelo casal Mário e Nenê Dal Pino em fins da década de 1940. Na foto 128, o hotel é visto à distância. No que parece ser um ambiente árido, a cerca de arame confere aspecto precário ao ambiente. $\mathrm{O}$ telhado, como o Toriba, era de duas águas. O formato irregular do papel fotográfico que com o corte acabou saindo torto, não interfere no conteúdo da imagem, que o figura emoldurado em primeiro plano pela mata nativa, e distanciado do caminho no qual estava o fotógrafo. A sensação é que o grupo estava chegando ao local e a tomada indica que logo desfrutariam do conforto das instalações.

A foto 128 pode ser comparada àquela feita anos antes em Serra Negra (foto 112). O estilo arquitetônico é semelhante, porém o nome "Refúgio Alpino" evoca um cenário campestre idealizado e europeu. Pela foto pode-se ver que a construção não tinha ainda

\footnotetext{
${ }^{136}$ Atualmente ele ocupa uma área de 70.000 hectares.

${ }^{137}$ Até 2003 este hotel localiza-se em Vila Capivari e possuía 37 apartamentos. Ver: (SILVA, 2003: 119).
} 
duas marcas comuns e difundidas a partir dos anos 1960 na arquitetura de Campos: o uso do enxaimel ${ }^{138}$ e dos telhados com grande declividade, referência direta aos Alpes Suíços.

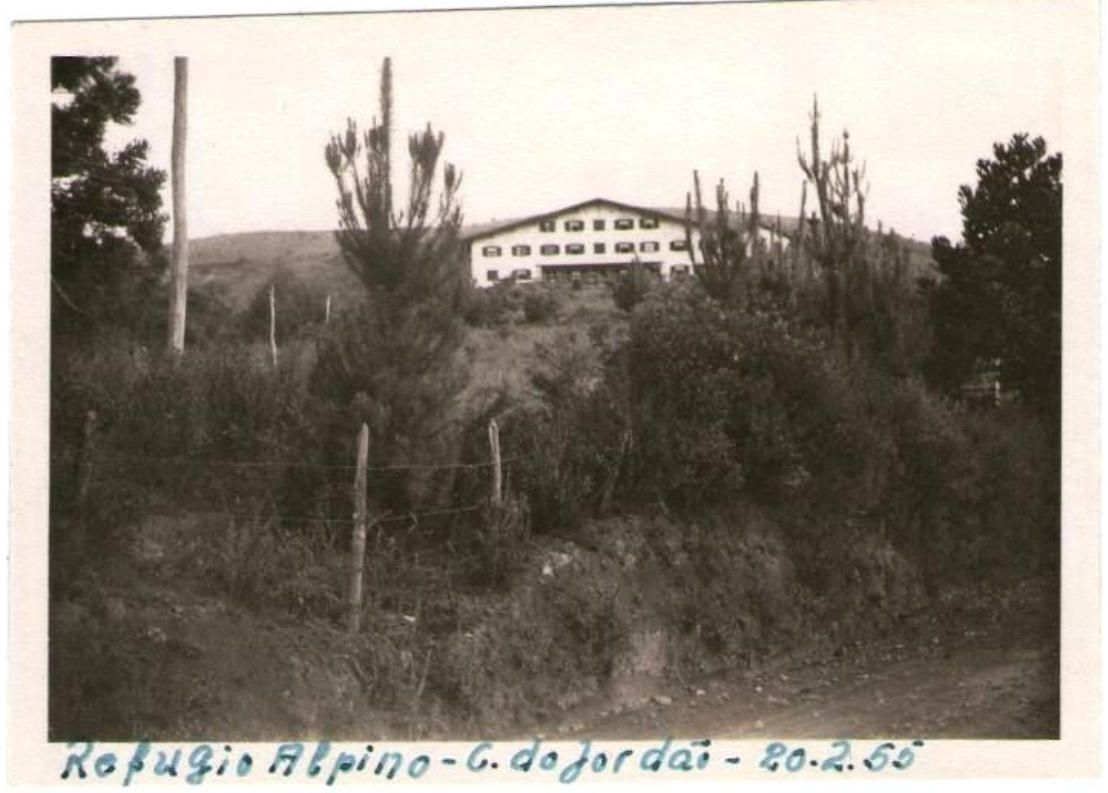

Foto 128: Hotel Refúgio Alpino, 1955. Ampliação das dimensões originais: 9 x 6 cm. Papel Leonar.

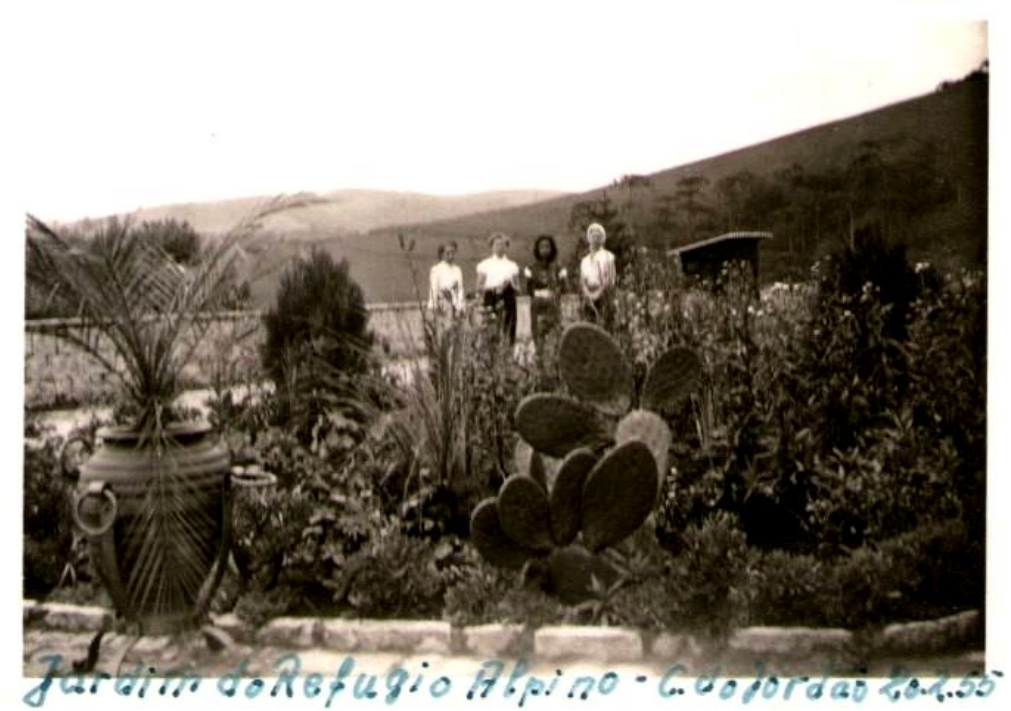

Foto 129: Jardim do Hotel Refúgio Alpino, 1955. Dimensões: 6 x 9 cm. Papel Leonar.

\footnotetext{
${ }^{138}$ Enxaimel são vigas e pilares de madeira aparentes que formam desenhos geométricos (Cf. Silva, op.cit. p.118).
} 
O recurso utilizado pelo fotógrafo para fazer a foto 129 , tendo em primeiro plano o jardim, é o mesmo aplicado à foto 74 (no SESC Bertioga). Tal estratégia emoldura o grupo, enquadrando-o entre um conjunto de elementos deliberadamente organizados à frente, com as montanhas ao fundo. Toda a parte superior da imagem correspondente ao céu fica lisa, homogênea e, seja em razão do estado do céu naquele momento ou das limitações tecnológicas da câmara, a luminosidade intensa pode ter anulado as nuvens, como já havia acontecido a outras imagens (fotos 112, 113, 123, $124,128)$

No "Bosque do Refúgio Alpino" (legenda original, foto 130), Cleonice, à direita da ponte, segura a mão do filho do casal Souza. À esquerda, Erika aproxima sua mão da do menino, mas elas não se tocam (detalhe 130a). A aproximação digital permite ver a distância entre os dois e revela a direção do olhar da criança voltado para o lado de Cleonice. Ao mesmo tempo em que o pequeno aprende a praticar, com seus próprios passos, os espaços destinados ao lazer, ao descanso e às férias, ele descobre como comportar-se diante do aparelho fotográfico. Conforme já visto, Cleonice assimilara maneiras de se colocar diante da câmara desde pequena. $\mathrm{O}$ menino, que caminha no bosque, tem, além da mãe, irmã e pai, talvez, agora também uma madrinha ou tia (como classificar Cleonice em relação à família Souza?). O mais curioso nesta foto é que se trata não exatamente da pose, mas do movimento das figuras em primeiro plano.

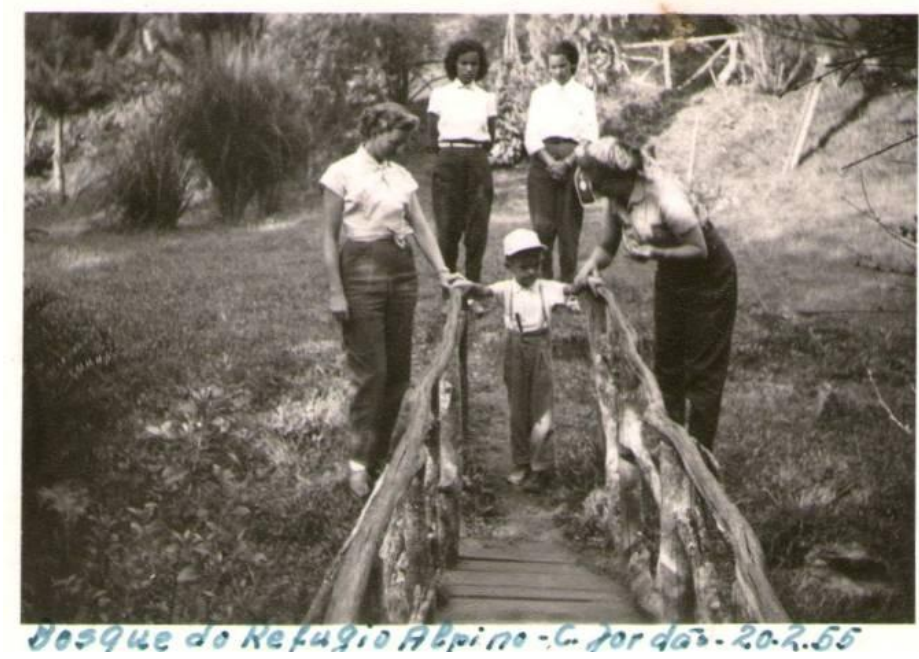

Foto 130: Érika, à esquerda, e Cleonice acompanham o trajeto do filho anônimo do casal Souza no Bosque do Hotel Refúgio Alpino, Campos do Jordão, 1955. Dimensões: 6 x 9 cm. Papel Leonar. 


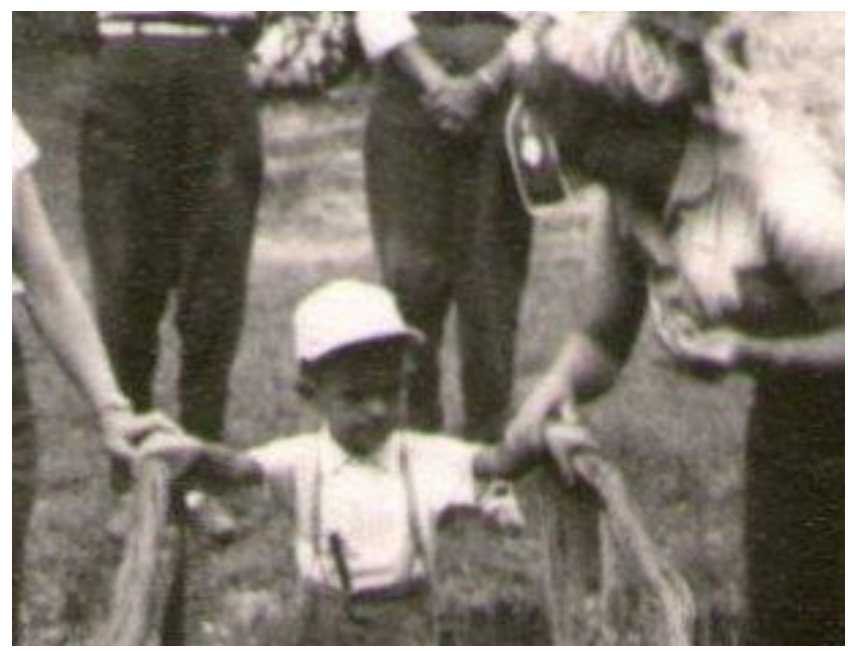

Detalhe 130a: O filho do casal Souza e Cleonice.

A proximidade entre Cleonice e o menino transparece melhor na foto 131, "Fonte da Juventude", tirada por Dircinha no último dia de passeio. Ela e o garoto destacam-se na cena, enquanto que o casal Souza fica descentralizado à direita. Nesse ato afetivo, Cleonice repetia, em certa medida, o mesmo que fez com Dircinha quando esta era pequena.

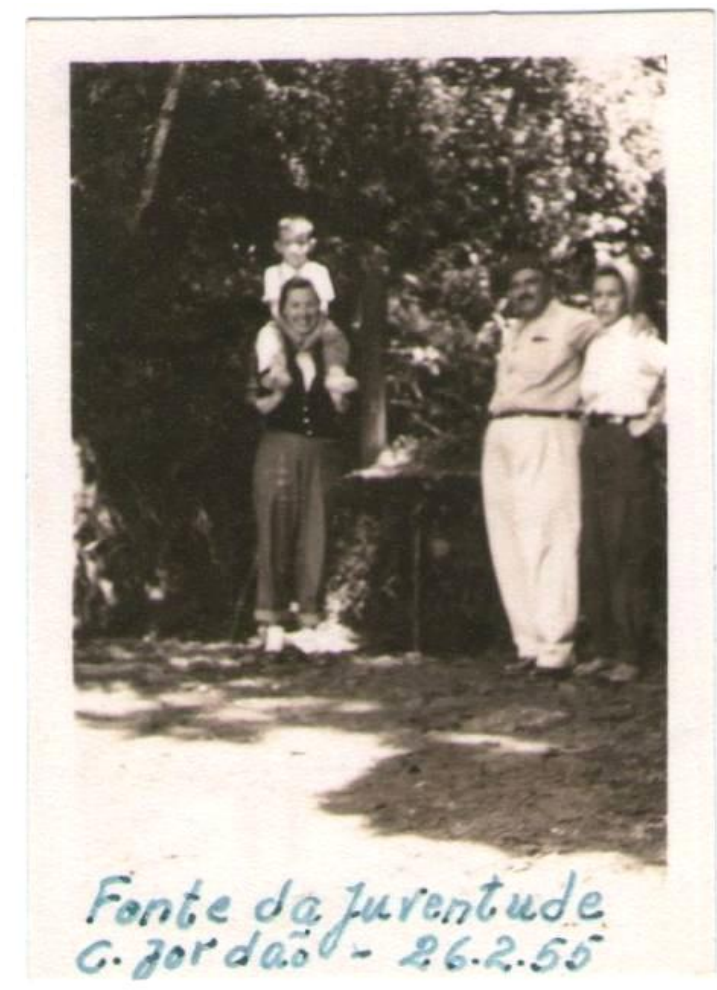

Foto 131: Cleonice e a família Souza na "Fonte da Juventude" em Campos do Jordão. Ampliação das dimensões originais: 4,5 x 6,5 cm. Papel Leonar. 
Três dias antes da foto 131 eles estiveram na área do Hotel Umuarama, criado em 1929 por entidades protestantes. Deste estabelecimento foram feitas quatro fotos. Nenhuma delas, contudo, exibe a fachada do hotel, pelo contrário, figuram apenas o “Lago Hotel Umuarama” (foto 132) e o "Bosque Hotel Umuarama” (foto 133).

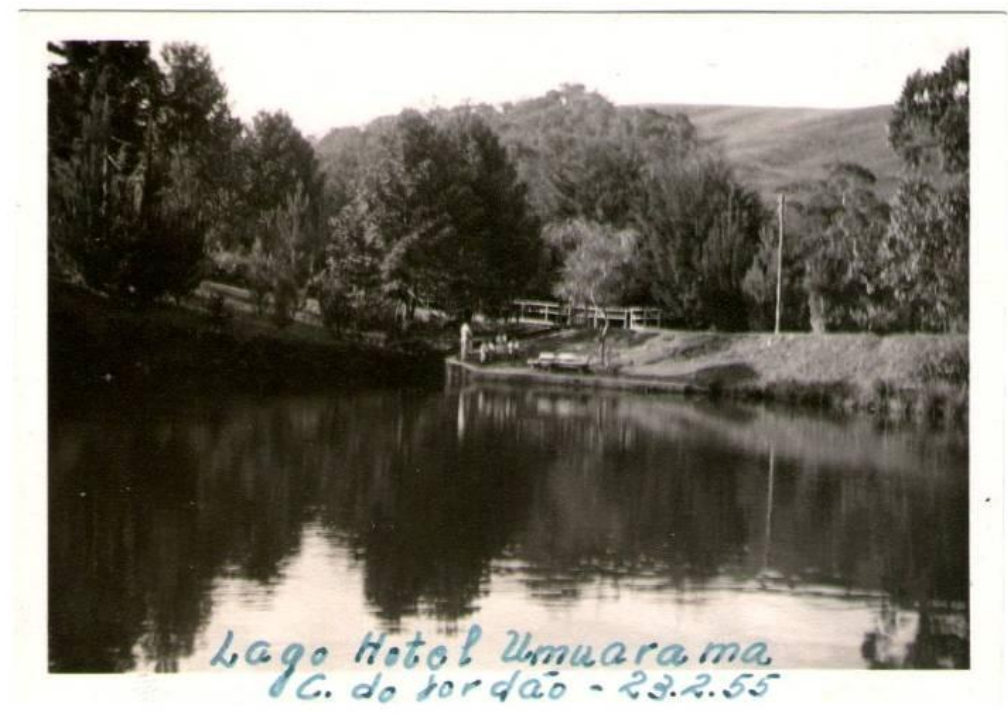

Foto 132: Lago do Hotel Umuarama - Campos do Jordão, 23.2.55. Ampliação das dimensões originais: 6 x 9 cm. Papel Leonar.

A imagem apresenta os vários elementos que constituem o imaginário da tranquilidade e campestres. Nada remete à vida nervosa experimentada na área urbana da capital paulista de três milhões de habitantes. Tais cenas são o oposto da série de fotos das celebrações do IV Centenário de São Paulo, onde os prédios enormes não davam descanso aos olhos, e onde Cleonice e o Sr. Velloso atuavam profissionalmente no setor químico. Do outro lado da margem, algumas pessoas (impossível saber quem são) estão juntas, usam roupas claras (detalhe 132a). Entre os elementos paisagísticos visíveis no detalhe, destaca-se o que parece ser uma ponte, no plano de fundo; bem perto da água dois bancos permitem aos visitantes contemplar os atrativos deste local aprazível. 


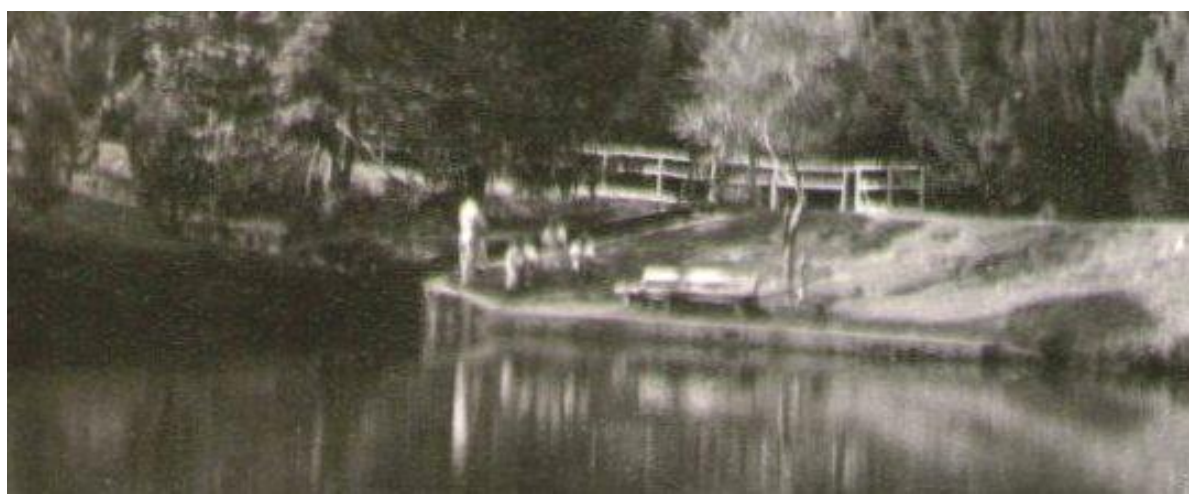

Foto 132a: Detalhe do Lago do Hotel Umuarama.

A visita ao Umuarama foi feita um dia depois da partida de Erika e nas fotos 133 e 134 os trajes expressam a mudanças da temperatura. O Sr. Souza estufa o peito e não encara a câmara, cujo olhar fotográfico é o de sua filha Dircinha, que centralizou bem o grupo equilibrando as figuras na composição (foto 133). $\mathrm{Na} 134$, o pai retoma o aparelho, enquanto Cleonice e o menino repetem nas duas imagens o mesmo gesto dos braços, porém ocupando outras posições. Esse novo arranjo na pose modifica também o espaço em questão. Desse modo, o lago que aparece na foto 134, não existe na foto 133. A fotografia novamente é um elemento modificador do espaço.

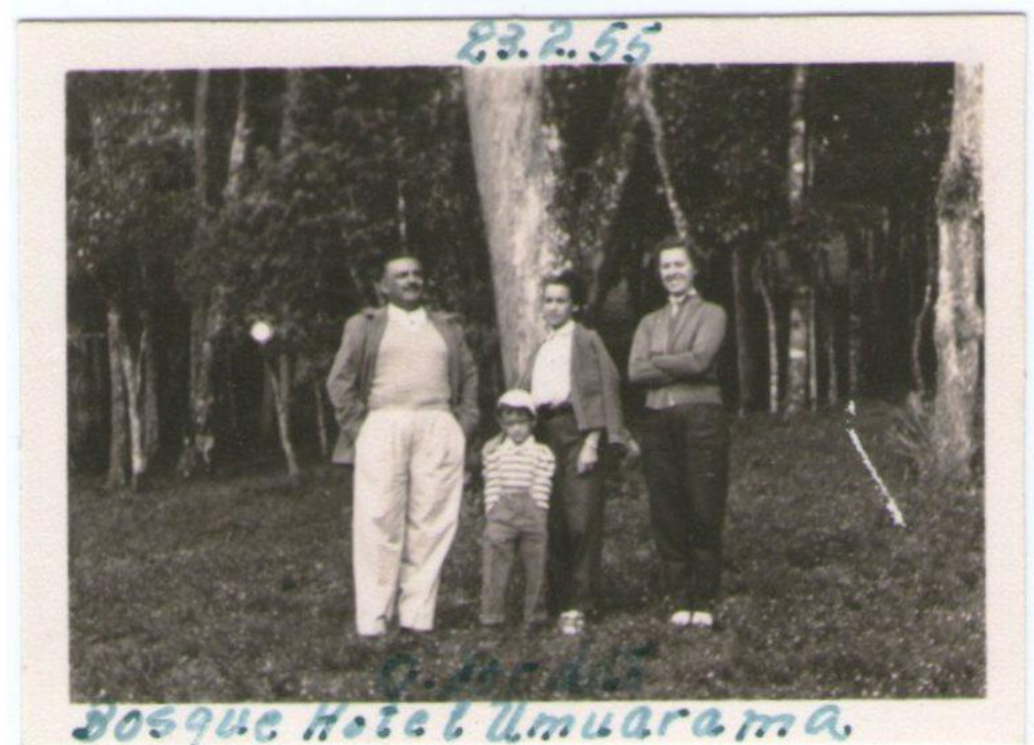

Foto 133: Cleonice, à esquerda da família Souza. Ampliação das dimensões originais: 6 x 4,5 cm. Papel Leonar. 


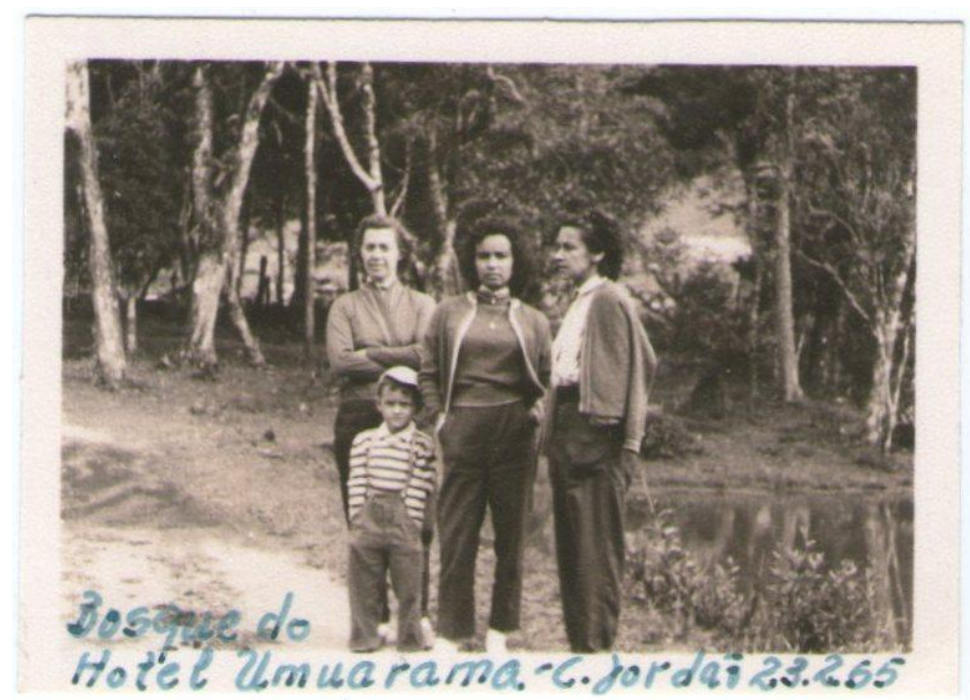

Foto 134: Cleonice, à esquerda, com a família Souza. Ampliação das dimensões originais: 6 x 4,5 cm. Papel Leonar.

\title{
3.7. Morro do Elefante e Pico do Itapeva
}

\author{
"Era uma subida dificil, com um percurso \\ ingreme, onde somente o clarão da lua nos \\ permitia pisar em bases mais seguras, evitando \\ que pudéssemos enfiar os pés nos muitos \\ buracos do caminho". (Edmundo Ferreira da \\ Rocha, 1993) ${ }^{139}$.
}

${ }^{139}$ O historiador e colecionador de fotografias Edmundo Ferreira da Rocha, que nasceu e vive em Campos do Jordão. Em sua homepage ele afirma: "O site da saudade, da história e da cultura de Campos do Jordão".Disponível: http://www.camposdojordaocultura.com.br/vercronicas.asp?Id_cronica=48\&Assunto=As+escaladas+notu rnas+pela+tromba+do+Morro+do+Elefante. Acesso em 29/8/2012. 


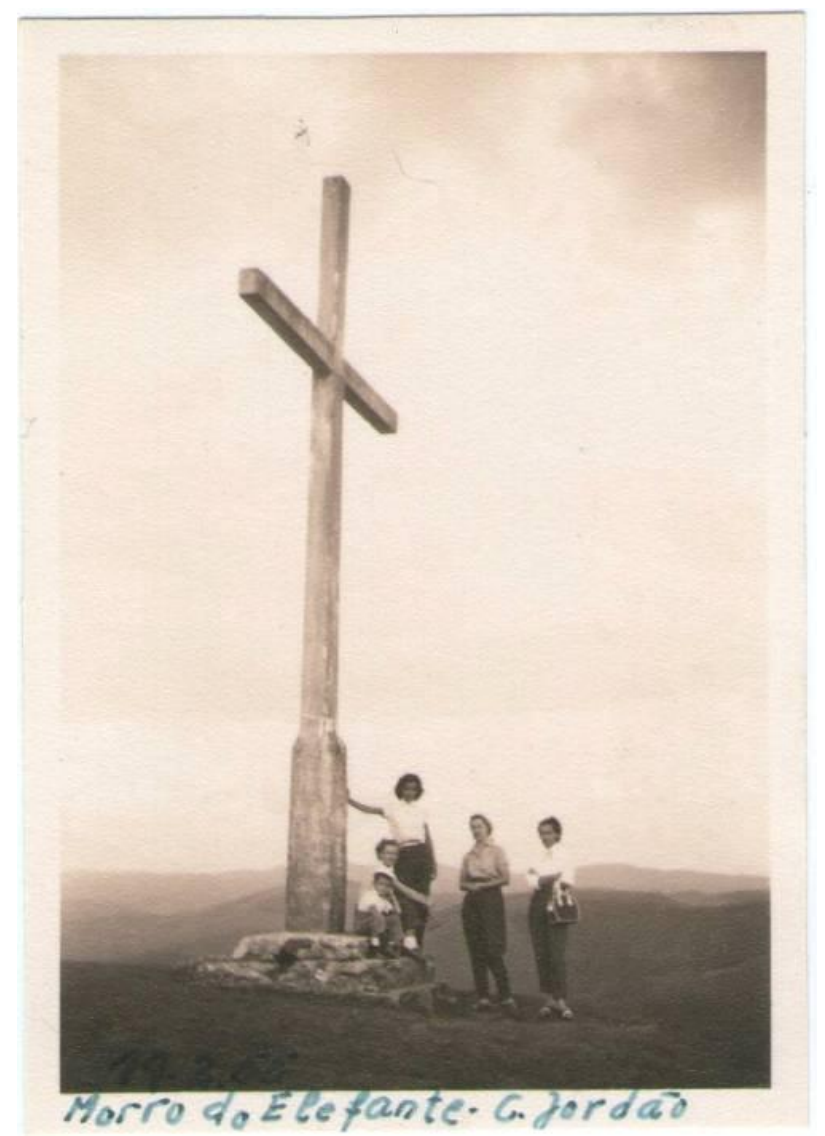

Foto 135: Morro do Elefante em Campos do Jordão, 1955. Ampliação das dimensões originais: 6 × $9 \mathrm{~cm}$. Papel Leonar.

No dia 19/02/1955, o grupo vai ao Morro do Elefante a uma altitude de 1.800 metros. O formato da fotografia 135 realça a verticalidade do motivo: a cruz de cimento, as mulheres de pé no topo do morro. As roupas, talvez em função da subida que devia esquentar o corpo, são mais leves se comparadas às fotos 133 e 134. A forma da montanha não aparece na foto, pelo contrário o elemento que ganha destaque é mesmo a cruz monumental na qual Dircinha encosta a mão ${ }^{140}$.

Essa é a única imagem do Pico nesta série, mas Cleonice e amigos estiveram também em outra importante formação rochosa: o Pico do Itapeva a 2030 metros de altitude. A visão do alto permitiu fixar o movimento das nuvens, que, ao passarem sobre a cadeia de montanhas, escureceram completamente o primeiro plano encobrindo o sol. Tal ação da natureza surtiu um efeito dramático que jamais se repetiria novamente. Daí

\footnotetext{
${ }^{140}$ De acordo com Cleide Pivott, o Pico do Elefante tinha esse nome porque, até meados dos anos 1970, o morro tinha a forma de um "elefante deitado" (2006:159). Segundo o empresário Marcelo Saraiva Mazza: "O termo 'Morro do Elefante' surgiu no passado atribuído por algumas pessoas que visitaram a cidade e entenderam que, de acordo com o ângulo de visão, o morro tinha a forma do dorso de um elefante" (MAZZA, apud PIVOT, p.159).
} 
a justificativa do registro fotográfico turístico da paisagem. A massa escura do primeiro plano, definida e compacta, distingue-se do fundo como a sugerir que entre esse plano e a área acinzentada distante houvesse um precipício cujo limite é a distância que o fotógrafo tomou enquadrando o panorama. Uma bolinha branca sobre a área inferior escura indica, por sua luminosidade, que o sol estava momentaneamente escondido, mas que a câmara sensivelmente reteve um raio de luz que parece uma mancha de sujeira. A subida ao pico permitiu ao grupo, além do fotógrafo, ver várias das cidades do Vale do Paraíba.

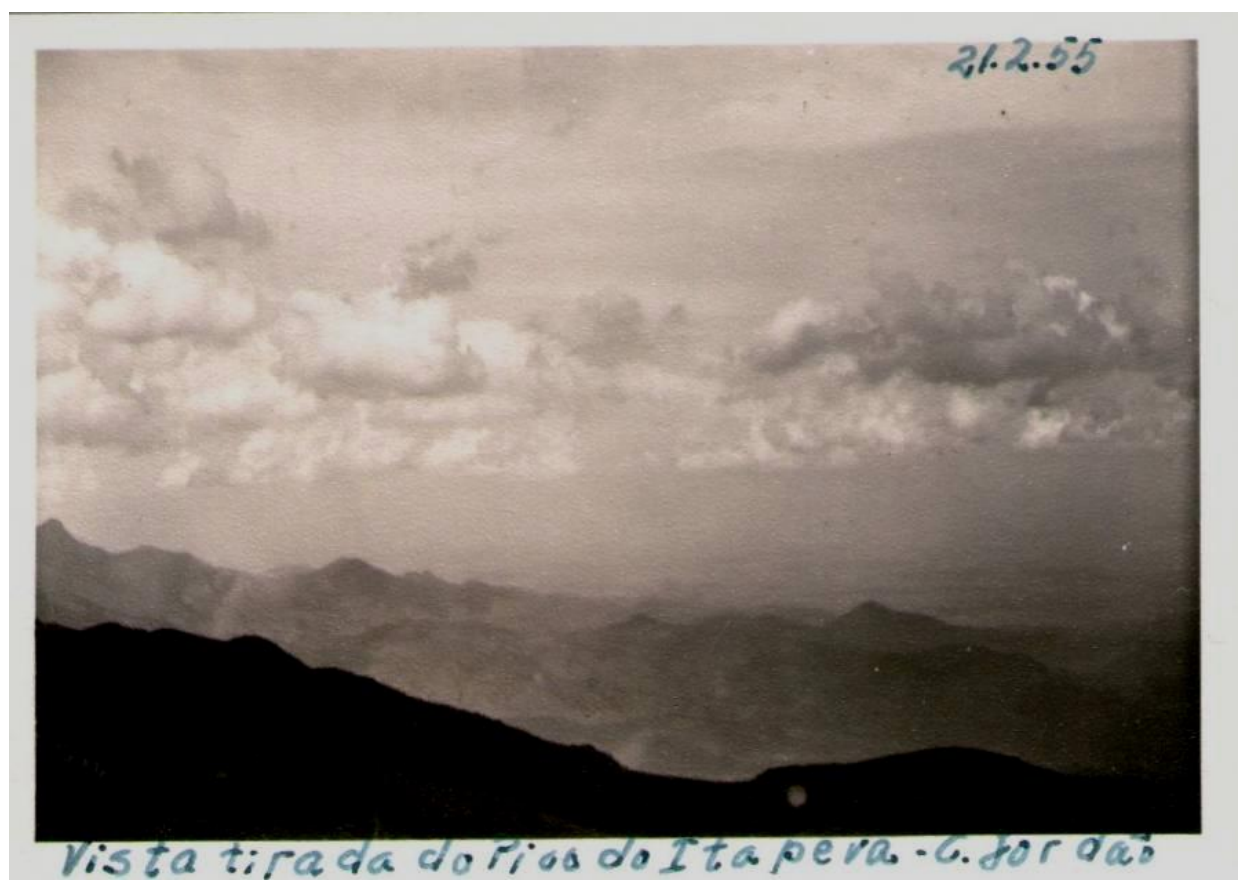

Foto 136: Vista do Pico da Itapeva, Campos do Jordão, 1955. Ampliação das dimensões originais $6 \times 9 \mathrm{~cm}$. Papel Leonar.

Se esta foto grandiosa e solitária destaca a beleza da paisagem - afinal os turistas foram completamente eliminados da cena - na foto 137, não só Cleonice e seu grupo aparecem, mas juntam-se a eles anônimos turistas, que acabaram ganhando importância nas composições. A irregularidade do terreno pode ser percebida pelo modo como as figuras humanas aparecem em diferentes elevações. Assim o fotógrafo põe-se abaixo captando não só as poses, mas também a atitude espontânea de alguns turistas. 


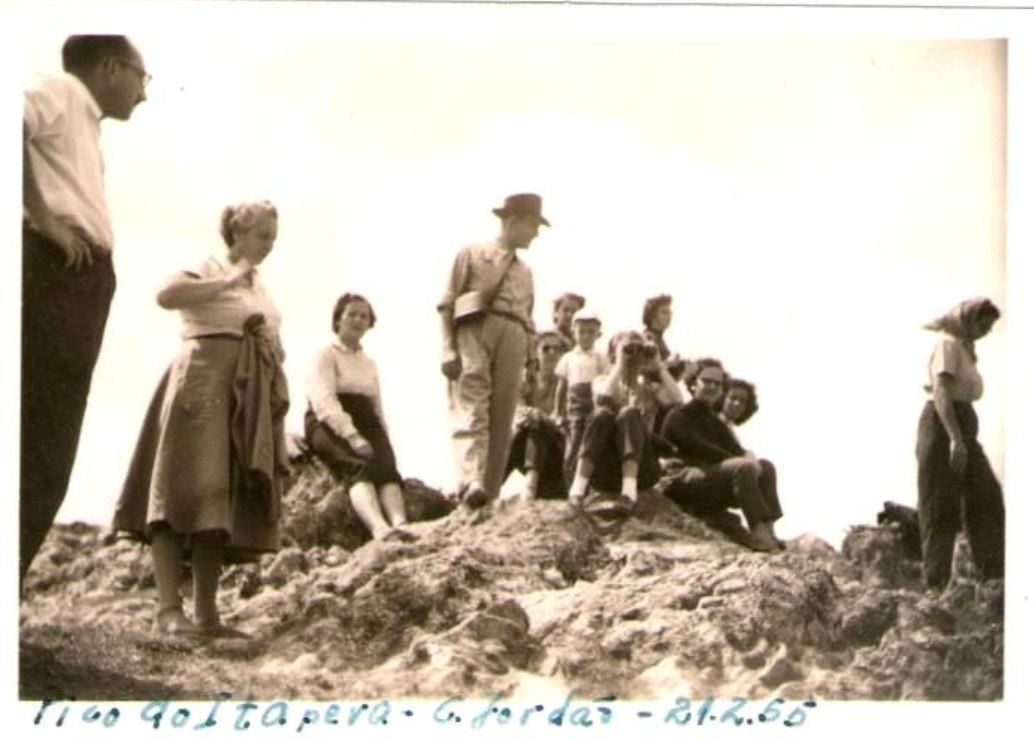

Foto 137: Cleonice entre membros da família Souza e anônimos no Pico da Itapeva, Campos do Jordão 1955. Ampliação das dimensões originais: 6 x 9 cm. Papel Leonar.

Cleonice e a família Souza estão dividindo espaço com outros viajantes que, como eles, vão a passeios, caminham, andam em trilhas, sobem e descem terrenos de grande declividade aproveitando as atrações turísticas divulgadas pela Prefeitura em seu mapa (figura 11). São transeuntes, possivelmente no ponto mais alto do Pico. Cleonice aparece de óculos escuros à direita, sentada entre Dona Olga e a criança. Entre eles, alguns anônimos e, mostrando apenas a cabeça, sentada um pouco mais abaixo, está Dircinha à extrema esquerda (detalhe 137a).

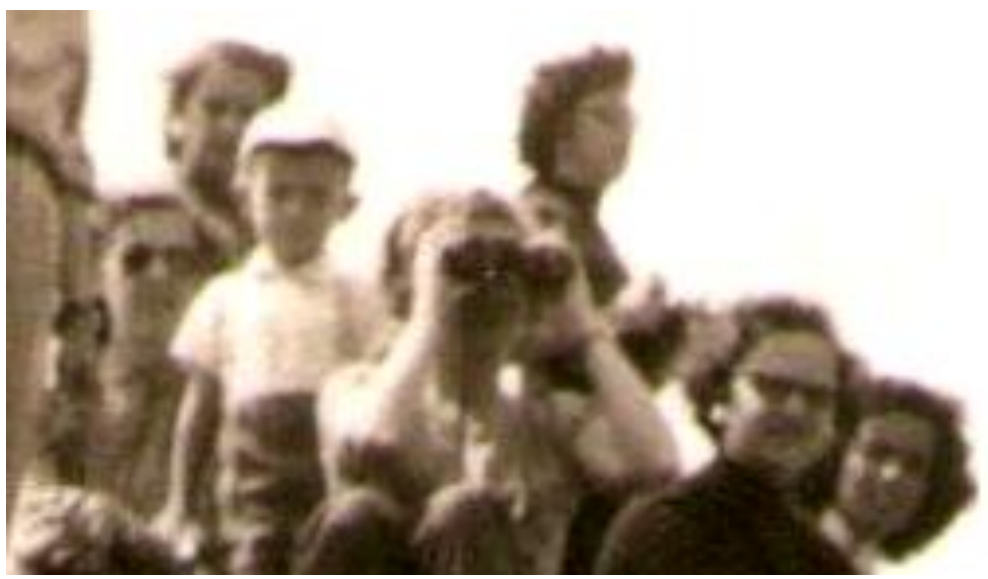

Detalhe 137a: No qual se pode ver Cleonice de óculos escuros e de perfil, tendo atrás dela Olga e, mais abaixo, Dircinha à extrema esquerda sem óculos. 
Essas figuras anônimas, talvez, estivessem também hospedadas no Toriba, no Umuarama ou no Refúgio Alpino. É interessante notar como as mulheres se relacionam diretamente com o fotógrafo, como a que está sentada sobre a rocha à direita no detalhe 137b e mesmo a de óculos bem ao lado de Dircinha no detalhe 137a.

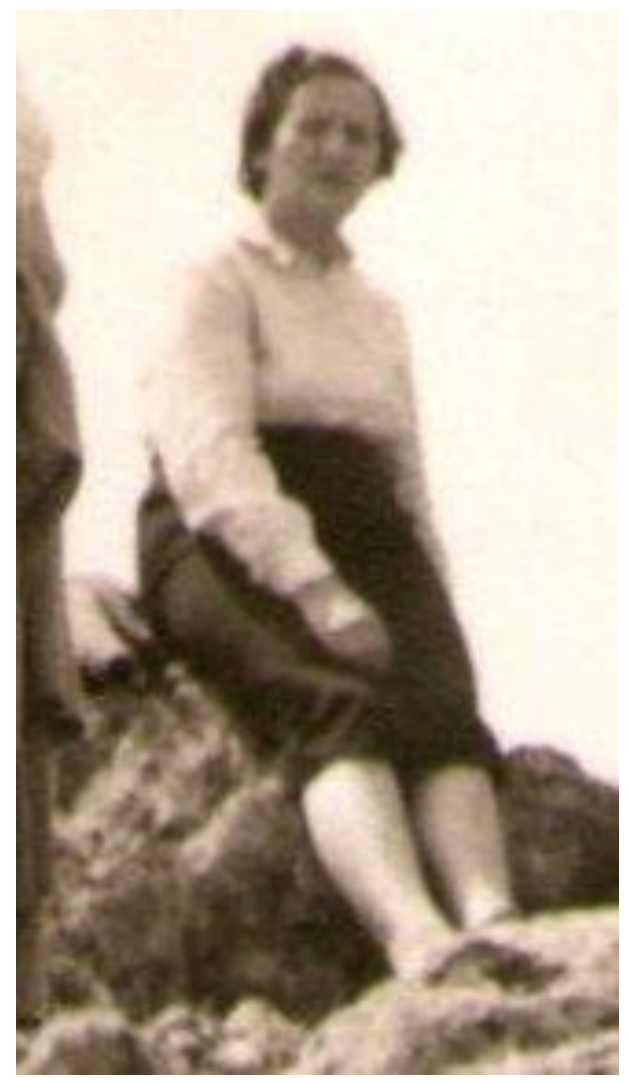

Detalhe 137b: Anônima. 


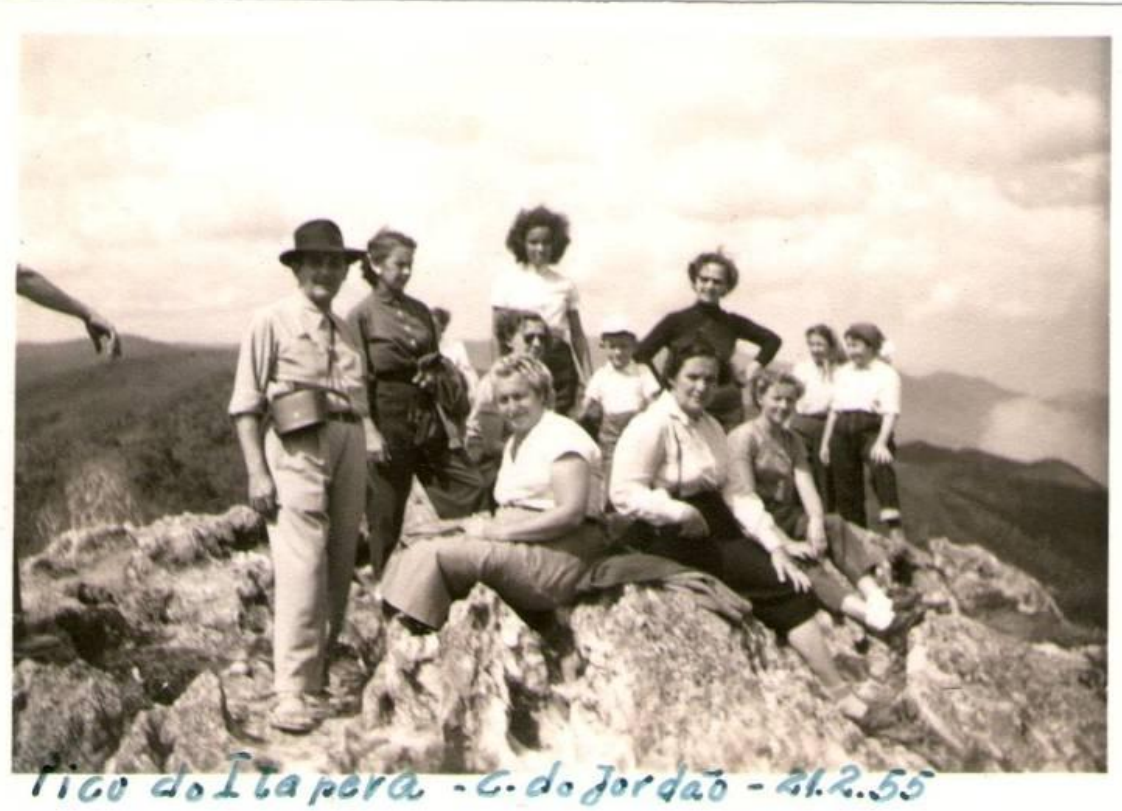

Foto 138: Anônimos em primeiro plano no Pico da Itapeva, Campos do Jordão, 1955. Ampliação das dimensões originais: 6 x $9 \mathrm{~cm}$. Papel Leonar.

Aqueles a quem chamo anônimos ocuparam completamente o primeiro plano. A mulher como no detalhe, (137b), novamente se relaciona com o fotógrafo, encarando a câmara. Algumas posições foram modificadas. Apenas Cleonice e o pequeno continuaram quase no mesmo lugar (mas, atrás dela agora está Dircinha em pé trajando camisa branca). À direita, de pé e de perfil está Dona Olga e o fotógrafo posiciona-se quase no mesmo plano dos fotografados relacionando-se com praticamente todos os presentes. Ambos - fotógrafo e visitantes - compartilham nesse momento a experiência social de contemplação da paisagem do local. Experiência frisada pela Revista do Comerciário sobre Campos do Jordão: “A contemplação dos seus vales e montanhas é um convite à meditação" 141 .

\footnotetext{
${ }^{141}$ Revista do Comerciário n.18, setembro-novembro, 1957, p.23. Acervo GEDES SESC Memórias.
} 


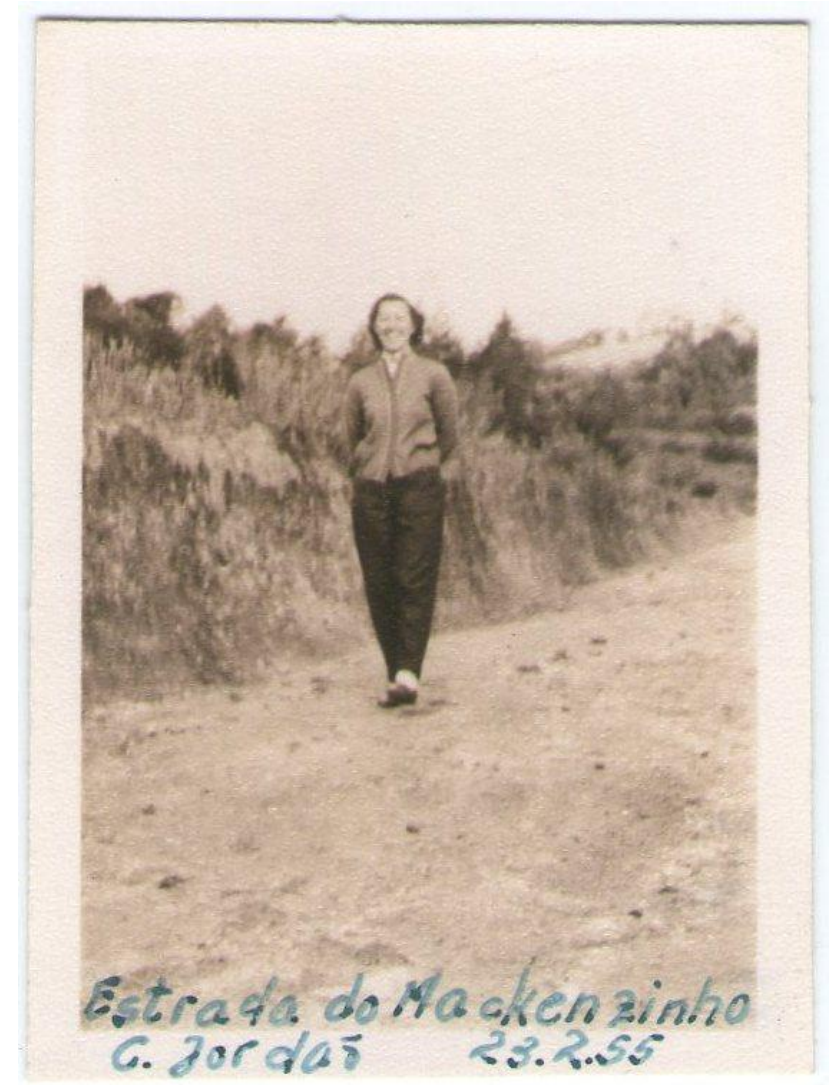

Foto 139: Cleonice na Estrada do Mackenzinho, Campos do Jordão, 1955. Ampliação das dimensões originais: $6,5 \times 9 \mathrm{~cm}$.

A imagem que encerra o capítulo (foto 139) é reveladora do cruzamento entre subjetividade e sociabilidade na documentação fotográfica que Cleonice acumulou. Aqui ela é o tema, estrutura sozinha a cena (como nas fotografias 47, 120 e 121). Como está em movimento em uma rua, essa imagem lembra a foto 25 , tirada no Clube de Regatas Tietê. A legenda é provavelmente uma referência ao Hotel Umuarama que, nos anos 1960, se tornaria uma colônia de férias da escola Mackenzie em São Paulo.

As viagens de Cleonice e os Souza pelo interior revelam alguns dos traços fundamentais do turismo de diversão que começava a se impor nestas regiões. Ele viria a sobrepor ao curismo religioso e o curismo científico. O discurso em torno da saúde, porém, está presente nestas três dimensões dos destinos campestres por eles visitados.

No que toca mais diretamente a fotografia, ela formaliza a viagem, dando-lhe contornos precisos: a vista panorâmica, as fachadas dos edifícios, o caminho de terra nos arredores do hotel, caminhadas ou cavalgadas. As imagens são pontos de parada, nos quais emerge as escolhas do fotógrafo e do grupo no momento de produção do registro. O lugar onde se posou revela a importância sócio-cultural de certos cenários, então na moda, como vimos. 
Embora sejam cidades nas quais a cultura aquática tinha importância, na fotografia a viagem ganha forma pela distância dos corpos em relação a água. Não vemos banhos de cachoeira, rios e mesmo piscinas, embora todos estes elementos configurem a especificidade dos atrativos do interior montanhoso. Por meio da análise dessas imagens buscou-se recuperar aspectos gerais do incremento comercial em torno das viagens turísticas com a construção de infra-estrutura inédita apreensível na combinação entre imagem e legenda.

Depois desta viagem, vieram outras neste mesmo ano de 1955, no mês sete para o Rio de Janeiro e também para Andradas e Poços de Caldas, cidades mineiras, em 1956 e 1959, respectivamente. Paralelamente, alguns passeios na capital continuavam também a gerar fotos, como a visita a São Miguel Paulista, Mogi das Cruzes e Mairiporã. A partir de meados da década de 1950 diminuiu gradativamente o acúmulo de registros de viagem na coleção $\mathrm{CMH}$. Já a última série de fotos suas junto à família Souza é de seu batismo e primeira comunhão em 1960 (foto 10). Desse momento em diante restou um álbum fotográfico com 28 fotos coloridas que a retratam basicamente nos limites do mundo doméstico, de sua própria casa, no convívio entre parentes e amigos, todos idosos e sorridentes.

\section{Considerações finais}

A fotografia é o passado no presente e a reminiscência no futuro (frase carimbada no verso da foto 47)

Que rendimentos analíticos podem ser obtidos quando se trabalha com restos materiais? O que esses resíduos biográficos, fruto de uma experiência social específica, dão a ver da vida social em um determinado contexto histórico? Como fazer um estudo cruzado entre biografia, cultura visual e imaginários urbanos entre 1920-1960? Como conhecer fenômenos mais gerais da cultura de um determinado período olhando para as práticas de consumo de uma pessoa, de um pequeno grupo? Estas são algumas das questões que me acompanharam durante a pesquisa e que continuam a me desafiar a formalizar respostas. 
Merecem destaque o papel do consumo de fotografias, mas também do consumo de espaços e paisagens, propriamente o fenômeno do turismo. Essa discussão percorre todo o trabalho. No capítulo 1 esse consumo é centrado na família de Cleonice por meio do qual verificou-se um duplo circuito a um só tempo afetivo e comercial em intenso diálogo. A fotografia no primeiro caso tinha, entre outras, uma função prática de aproximar parentes distantes, reforçar e manter laços. Sustentando estas trocas estava o circuito comercial concentrado basicamente nas antigas ruas de comércio visual do centro. Neste sentido a pesquisa contribui para compreendermos a dinâmica, ainda pouco conhecida, da relação entre a família como consumidora e o mercado produtor de bens e serviços fotográficos. Nos anos 1940, no momento em que a capacidade de consumo de Cleonice aumenta, verifica-se também o incremento deste mercado pelo surgimento de lojas e estúdios fotográficos em outras ruas do centro. Esses estabelecimentos disputavam consumidores e ofereciam: revelações, ampliações, equipamentos, envelopes, ou prometiam atendimento especializado como a Papelaria Léo que se distinguia como o "Amigo dos amadores". O papel do mercado era garantir a realização dos desejos de representação, autorrepresentação e documentação da vida de indivíduos e grupos.

Uma contribuição da pesquisa refere-se ao estudo de algumas formas de lazer na cidade. Procurei chamar a atenção para a importância da presença alemã na educação, na indústria da fotografia e da química, mas também para um certo lazer desse grupo e seus descendentes, como era o caso de Cleonice Heine. Tais práticas não se restringiam à capital paulistana, imigrantes europeus, e alemães em particular, estão ligados ao gosto pelos passeios e contemplação da natureza tanto campestre quanto litorânea.

Outro aspecto que merece ser destacado são as transformações urbanas ocorridas em São Paulo no período, cuja abrangência se extende para muito além da capital modelando mesmo os inéditos destinos turísticos. Trata-se em resumo da comunicação promovida com o enriquecimento da cidade. A entrada das mulheres no mundo do trabalho e sua capacidade de consumo e mobilidade espacial, também são fundamentais nessa cidade em mutação. Essa emergência do trabalho feminino na área de comércio e serviços é indicativa da complexidade que vinha assumindo a vida urbana e seu recrutamento decorria de fatores como escolaridade, disposição para ganhar menos, sendo a mobilidade espacial consequência desta nova condição de gênero, mas que isoladamente não a garantia. Sendo solteira, era necessário a Cleonice ter uma rede de sociabilidade, isso parece ter- lhe permitido deslocar-se com desenvoltura como se vê 
em suas fotos. Na medida em que a cidade se transformava devido a sua gradual importância como lócus de concentração de riquezas, surgia uma infraestrutura de lazer na capital e de lazer e turismo no litoral e no campo. A "popularização" e "democratização" da fotografia são parte destas mudanças, tornando-se suporte privilegiado da memória individual e coletiva. Isso corresponde a dizer que a fotografia produz subjetividades e sociabilidades, e essa dicotomia está presente todo o tempo nas imagens analisadas.

Nos capítulos 2 e 3 a fotografia acompanha a viagem e dá forma a experiência de deslocamento para lugares recentemente surgidos, por um lado como uma saída diante da crise do café, como as pensões no litoral paulista (capitulo 2), ou a consequente valorização cultural e comercial dos elementos da natureza como capazes de curar e divertir (capitulo 3). Essas mudanças acompanham a conformação de uma classe média urbana, para quem o lazer vai ganhar importância, sobretudo com a valorização do rodoviarismo e dos automóveis, quanto da possibilidade da aquisição a crédito de segundas residências em prestações em localidade litorâneas que à época não eram tão valorizadas.

Cleonice Maria Heine fez um "arquivo de vida", com sua coleção de fotos, na feliz expressão de Philipe Artières (1998), construiu uma imagem para si e para os outros. Como intérprete, notei a presença marcante de séries de "relatos de espaço" como sugere Michel de Certeau (1996). A importância que ela deu à identificação dos lugares em detrimento das pessoas é prova disso. Daí ter sido possível ultrapassar a especulação estéril sobre episódios de sua biografia e, ao contrário, mergulhar no que essa reunião de registros tem de excepcional: a experiência social urbana repleta de novidades, entre as quais a escolarização das mulheres das camadas médias, sua entrada no sistema produtivo, sua condição de comerciária, turista e consumidora.

O presente trabalho transformou radicalmente minha forma de entender a história, a cultura e o imaginário urbano na cidade de São Paulo entre 1920 e 1960. Minha pretensão não foi ilustrar o trabalho com as fotos, mas partir delas como resíduos históricos e biográficos, recuperando as condições sociais que permitiram a Cleonice herdar e posteriormente consumir fotografias, montando assim uma essa coleção.

Procurei mostrar como a fotografia não é apenas testemunho, captação e prova da existência da realidade; ela produz o real, fragmentando-o, compondo-o com os códigos que lhe são próprios: cortes, ângulos, distâncias e aproximações, 
enquadramentos que, muitas vezes, iludem quanto à realidade da qual pretende ser uma imagem fiel. Isso ficou explícito na maneira como o olhar turístico tende a ficar restrito a descrição das fachadas dos locais visitados, ou na forma como a praia eventualmente aparece vazia de interações humanas, quando de fato já era destino de grande quantidade e diversidade de pessoas nas primeiras décadas do século XX (SEABRA, 1979).

Finalmente, poderíamos pensar que, ao colecionar episódios fotográficos de sua vida, Cleonice usou a fotografia como uma plataforma de encenação de múltiplos papéis sociais, talvez até como forma de "resistência" diante do peso social, no contexto em que viveu, de não ter casado. Não sugiro nada de negativo nesse fato, pois o que transparece nas fotos é que ela soube negociar essa condição, estabelecendo importantes laços de solidariedade, especialmente com a família Souza, deixando entrever uma certa "arte de viver".

Uma vez que se trata de uma coleção razoavelmente grande, gostaria de sugerir finalmente, à guisa de conclusão, alguns possíveis desdobramentos desta pesquisa. Seria interessante um estudo comparativo entre a coleção $\mathrm{CMH}$ e a coleção $\mathrm{GH}$. Estas poderiam ser estudas a partir das formas de acumulação praticada por ele em contraste com ela. O corpus de análise poderia ser ampliado observando a recorrência de formatos, dimensões, tipos de revelação, endereços comerciais de venda de produtos e temas fotografados, contrastando diferentes experiências urbanas. Na relação mais direta entre fotografia e sociedade, seria interessante observar como a experiência de gênero, a subjetivação feminina e a ocupação profissional configuraram uma cultura urbana, na qual o consumo foi elemento importante. Isso implicaria também pensar a relação entre fotografia, corpo, experiência urbana e experiência turística e de lazer. Adicionalmente, um olhar atento em direção aos circuitos de consumo fotográfico e turístico permitiria entender melhor como se deu, entre as camadas médias da população paulistana, a "democratização" do acesso à fotografia e ao turismo.

Outra possibilidade, essa mais ligada à geração de um produto decorrente desse trabalho seria a criação de um banco de dados explicitando a metodologia de tratamento da fonte (organização, catalogação, classificação, descrição, armazenamento, análise e interpretação da coleção). Esse produto seria uma contribuição para o estudo da cultura visual fotográfica privada na primeira metade do século $\mathrm{XX}$ até inicio da segunda metade em São Paulo. Esse banco de dados poderia ser socializado com pesquisadores e instituições interessadas em conhecer e estudar o período a partir das práticas e de atores 
sem notoriedade. Tal contribuição seria útil também ao campo de estudos etnohistóricos voltados para a análise da cultura visual fotográfica e da cultura urbana em meados do século XX, atentando para o fato de ser esta coleção mais do que apenas uma narrativa individual, ao contrário, trata-se de uma experiência social vigorosa para entender aspectos da memória coletiva. 


\section{Fontes e acervos consultados}

\section{Arquivo da Cúria Metropolitana de São Paulo}

Registro de Batizados da Igreja de São Judas Tadeu - Jabaquara 1960, p.83, n. 2707. 75-18-9. Armário 28 - n. 17.

\section{Biblioteca Mário de Andrade}

Isto é São Paulo! 96 flagrantes da capital bandeirante. MELHORAMENTOS, 1951

\section{Acervo GEDES/SESC Memórias}

Documentos administrativos

Relatórios anuais do Departamento Regional do Serviço Social do Comércio 1947/48

Relatórios anuais do Departamento Regional do Serviço Social do Comércio 1948/49

Periódicos

Revista O SESC em Marcha - ano 1, novembro $n 1^{\circ}$ - 1949.

Revista O SESC em Marcha, maio/junho 1949.

Revista O SESC em Marcha, set/out. 1950.

Revista do Comerciário - Ano I - janeiro de 1956.

Revista do Comerciário n.17, setembro-outubro, 1957.

Revista do Comerciário n.18, novembro-dezembro, 1957.

Revista do Comerciário, n. 31, Junho, 1959.

Revista do Comerciário, n 32 Julho de 1959.

\section{Acervo particular}

Anuário das Senhoras, Ano XVI, 1949. Edições da Sociedade Anônima "O malho" BOURÉE, Charles. Fotografia prática ao alcance de todos. Manual prático que ensina a ser um bom fotógrafo-amador. Lisboa. Ed. Empresa Literária Universal. 1952.

\section{Acervo textual e Iconográfico do Museu Paulista da Universidade de São Paulo.}

Coleção de fotografias de Benedito Calixto de Jesus: IC. 03603 - 0000 - 0000; IC. 03599 - 0000 - 0000; IC. 1.03437 - 0000 - 0000; IC. 1.03445-0000-0000; 1-034390000-0000.

Coleção Lucia Salles Araújo, ICs. 22812 e 22813. 


\section{Acervo José Roberto Franco da Rocha}

Jornal de Serra Negra, 7 de janeiro de 2005.

\section{Referências Bibliográficas}

\section{Páginas Eletrônicas - sites e blogs}

Disponível em

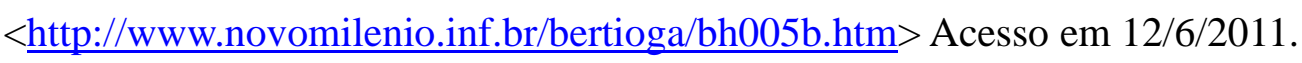

<http://www.ibge.gov.br/seculoxx/economia/atividade_economica/setoriais/transportes/tr ansportes.shtm> Acesso em 14/7/2011.

$<$ http://jornalcidade.circuitodasaguas.com/historico/ler.php?id=5292 $>\quad$ Acesso em $2 / 11 / 2011$

$<$ http://www.direitoshumanos.usp.br/index.php/Declara\%C3\%A7\%C3\%A3o-

Universal-dos-Direitos-Humanos/declaracao-universal-dos-direitos-humanos.html.> Acesso em 20/11/2011.

$<$ http://mob.aulete.com.br/site.php?mdl=aulete_digital\&op=loadVerbete\&pesquisa=1\& palavra $=$ mal\%E1ria $>$ Acesso 28/11/2011.

<http://jornalcidade.circuitodasaguas.com/historico/ler.php?id=4337>. Acesso em 22/12/2011.

<http://www.cervejasdomundo.com/Brasil3.htm > Acesso em 24/2/2012.

< http://www.martiusstaden.org.br/Events/MemoriasDeSP.aspx $>$ Acesso em 24/1/2012.

<http://www.jucesponline.sp.gov.br/Pre_Visualiza.aspx?nire=35206779843\&idproduto $=>$ Acesso em 6/2/2012.

<http://www.novomilenio.inf.br/santos/h0214.htm> Acesso em 22/2/2012. http://www.novomilenio.inf.br/bertioga/bh007.htm> Acesso em 29/2/2012. $<$ http://www.vitruvius.com.br/revistas/read/arquitextos/12.136/4034>Acesso 29/2/2012.

<http://www.novomilenio.inf.br/rossini/sts1950.htm > Acesso em 2/3/2012.

$\langle$ http://cpdoc.fgv.br/producao/dossies/JK/biografias/prestes_maia) Acesso em $13 / 3 / 2012$.

<http://bragamusician.blogspot.com.br/2011/12/ano-internacional-da-quimica-2011marie.html>.Acesso em 20/3/2012.

http://www2.uol.com.br/jornaldecampos/507/diretor.htm Acesso em 30/3/2012. $<$ http://www.biazigrandhotel.com.br/o-hotel > Acesso em 26/3/2012.

$<$ http://www.jucesp.fazenda.sp.gov.br/ > Acesso 23/4/2012. 
$<$ http://www.revistamuseu.com.br/emfoco/emfoco.asp?id=8901 >Acesso em 23/5/2012.

$<$ http://labjor.unicamp.br/patrimonio/materia.php?id=139> Acesso em 24/5/2012.

<http://www.dicio.com.br/saibro/> Acesso em 15/8/2012.

< http://www.biazigrandhotel.com.br/o-hotel> Acesso em 24/8/2012.

$<$ http://www.camposdojordaocultura.com.br/vercronicas.asp?Id_cronica=48\&Assunto=

As+escaladas+noturnas+pela+tromba+do+Morro+do+Elefante > Acesso em 29/8/2012.

<http://www.prefeitura.sp.gov.br/cidade/upload/fundos_documentais_1255023339.pdf> Acesso em 03/9/2012.

$<$ http://revistapesquisa2.fapesp.br/?art=4268\&bd=1\&pg=1\&lg=>Acesso em 18/09/2012.

<http://www.stj.jus.br/portal_stj/publicacao/engine.wsp?tmp.area=398\&tmp.texto=10130

5> Acesso em 25/01/2012.

<http://www.dicio.com.br/saibro/> Acesso em 15/8/2012.

$<$ http://crq4.org.br/default.php?p=texto.php\&c=quimicaviva_mariecurie_brasil $>$ Acesso em 20/3/2012.

<http://www2.uol.com.br/jornaldecampos/507/diretor.htm> Acesso em 30/3/2012.

AMARAL, Antonio Barreto do. Bairro de Pinheiros: História dos bairros de São Paulo.

São Paulo: Secretaria da Educação e Cultura, 1969.

AMERICANO, Jorge. São Paulo atual: 1935-1962. São Paulo: Melhoramentos, 1963.

ARTIÉRES, Philipe. “Arquivar a própria vida”, Estudos históricos, Rio de Janeiro, Fundação Getúlio Vargas, n. 21, 1998.

ARAÚJO, Íris de Morais. Militão Augusto de Azevedo: Fotografia, História e Antropologia. Alameda, 2010

AZEVEDO, Aroldo. "São Paulo: Da vila quinhentista a metrópole regional". Boletim Paulista de Geografia, n.39, São Paulo, 1961. p.p.12-46.

A cidade de São Paulo. Estudos de Geografia urbana. V. 3. Aspectos da metrópole paulistana. São Paulo: Companhia Editora Nacional. 1958 
BARBUY, Heloisa, Solange Ferraz de LIMA e CARVALHO, Vânia Carneiro de. O sistema documental do Museu Paulista: a construção de um banco de dados e imagens num museu universitário em transformação. IN: Imagem e produção de conhecimento. OLIVEIRA, Cecília Helena de Salles e BARBUY, Heloisa (orgs.). São Paulo - Museu Paulista - USP, 2002.

BARREIRA, Cristiane Antunes e SILVA, Ana Lúcia Gonçalves. Turismo de Saúde. Ed. SENAC, 1994.

BARREIROS, Mario Antonio Ferreira. Plano Metropolitano de Desenvolvimento Integrado - PMDI 2002. Região Metropolitana Baixada Santista. Cadernos Metropolitanos. Sistema de Circulação e Transporte. Caderno nº 5.2002.

BARRETTO, Margarita. "Relações entre visitantes e visitados: um retrospecto dos estudos sócio-antropológicos”. In: Revista Turismo em Análise, Vol. 15, n.2, Nov. 2004, p.133-149.

BARRO, Máximo. Senhora do Ó. São Paulo. Departamento do Patrimônio Histórico. 1977.

BARROS, Myriam Lins de, e STROZENBERG, Ilana. Álbum de família. Rio de Janeiro: Comunicação Contemporânea. 1992.

BARTHES, Roland. A Câmara Clara: notas sobre a fotografia. Tradução: Julio Castañon Guimarães. Rio de Janeiro. Nova Fronteira. 1984.

BASTIDE, Roger. Brasil Terra de contrastes. São Paulo: Difel. [1957] 1979.

BASTOS, Cristiana. "Banhos de princesas e de lázaros: termalismo e estratificação social". Anuário Antropológico 2010-11. Dezembro de 2011.p.p.107-126.

BELLAVANCE, Guy. "Mentalidade urbana, mentalidade fotográfica". Cadernos de Antropologia e Imagem n.4, UERJ, 1997. pp.17-28. 
BELOTTO, Heloisa Liberalli \& CAMARGO, Ana Maria de Almeida. Dicionário de Terminologia Arquivística. Imprensa Oficial do Estado de São Paulo, IMESP - Brasil 1996.

BENJAMIM, Walter. "Pequena história da fotografia", In: Magia, técnica, arte e política. Tradução Sérgio Paulo Rounet. Introdução Jeanne Marie Gagnebin. São Paulo, Brasiliense, 1994.

BERNARDINI, Sidney Piochi. “O público e o privado na expansão da rede ferroviária no estado de São Paulo no inicio do século XX”. In: Território e cidades: Projetos e representações, 1870-1970. CAMPOS, Cristina de, OLIVEIRA, Eduardo Romero de e GITAHY, Maria Lucia (orgs.) São Paulo: Alameda, 2011. p.p.41-70.

BESSE, Susan K. Modernizando a Desigualdade: Reestruturação da Ideologia de Gênero no Brasil 1914-1940. São Paulo: Edusp. 1999.

BIRMAN, Patrícia. O que é Umbanda. Coleção primeiros passos; Vol. 34; São Paulo: Abril Cultural: Brasiliense, 1985.

BOYER, Marc. Historia do Turismo de massa. Tradução: Viviane Ribeiro. - Bauru, SP: EDUSC. 2003.

BORIN, Paula. Divisão Interurbana do Trabalho e Uso do Território nos Municípios de Águas de Lindóia (SP), Lindóia (SP), Serra Negra (SP), Socorro (SP) e Monte Sião (MG). Dissertação de Mestrado do Programa de Pós-graduação em Geografia Humana da FFLCH-USP. 2002.

BOSI, Ecléa. 2003. "Memória da cidade: lembranças paulistanas". Estudos Avançados. Vol.17 no. 47. São Paulo Jan./Apr. 2003, p.p.198-211.

BRUNO, Fabiana. Fotobiografia, por uma metodologia da estética em Antropologia. Tese de Doutorado em Multimeios. Instituto de Artes -IA- UNICAMP, 2009.

CAETANO, Ana. "Fotografia e lembrança". Revista Sociologia, problemas e práticas $n$ 55. 2007. 
CALVINO, ITALO. “A aventura de um fotógrafo". In: Os amores difíceis. Tradução: Raquel Ramalhete. 2 edição. São Paulo: Companhia das Letras, 1992.

CAMARGO, Ana Maria de Almeida. “Arquivos pessoais são arquivos”. Revista do Arquivo Público Mineiro, Belo Horizonte, v. 45, n. 2, jul. - dez. 2009.

CARPINTÉRO, Marisa Varanda Teixeira. "Tempo e história no plano de avenidas". Urbana, ano 2, n.2, Dossiê: Cidade, Imagem, História e Interdisciplinaridade. CIEC/UNICAMP. 2007. p.p 1-11.

CARVALHO, Vânia Carneiro de. ALENCAR, Michele de Oliveira. "Por histórias das fotografias - do índice ao artefato". In: Registros Fotográficos, Patrimônio e Memória da USP. PINHEIRO, Maria Lucia Bressan (org.) São Paulo, Editora da Universidade de São Paulo, 2010.

. LIMA, Solange Ferraz. "Fotografias como objeto de coleção e de conhecimento: por uma relação solidária entre pesquisa e sistema documental”. Anais do Museu Histórico Nacional. vol. 32, 2000.

CARVALHO, Vânia Carneiro de e LIMA, Solange Ferraz. Fotografia e cidade: da razão urbana à lógica de consumo. Álbuns de São Paulo (1887-1954). Campinas. Mercado de Letras/ FAPESP, 1997.

LIMA, Solange Ferraz. CARVALHO, Maria Cristina

Rabelo de. Rodrigues, Tânia Francisco, "Fotografia e História: ensaio bibliográfico". Anais do Museu Paulista. História e Cultura Material. Nova série, vol. 2, Jan-Dez 1994.

CARVALHO, César Augusto de. "Os usos da fotografia de família". Antropologia e Imagem, vol. 1. PEIXOTO, Clarice Ehlers (org.) Garamond Universitária, FAPERJ, 2011,p.p.109-124.

CLAUDON, Francis. Enciclopédia do Romantismo. Verbo. 1986.

CORBIN, Alain. O território do vazio, a praia no imaginário ocidental. Tradução: Paulo Neves. São Paulo. Companhia das Letras. 1989. 
. "O segredo do indivíduo". In: História da vida privada: Da revolução

francesa à Primeira Guerra Mundial. Tradução Bernardo Joffily. São Paulo. Companhia das letras. Vol. 4. 1999.

CORREA, Sílvio Marcos de Souza. "Germanidade e banhos medicinais nos primórdios dos balneários no Rio Grande do Sul”. História, Ciências, Saúde-Manguinhos, Rio de, Vol.17, n.1, jan.mar. 2010, p.165-184.

COSTA, Helouise \& SILVA, Renato Rodrigues da. A Fotografia Moderna no Brasil. São Paulo: Cosac Naify, 2004.

DE CERTAU, Michel. A invenção do cotidiano: artes do fazer. Tradução: Ephrain Ferreira Alves. Petrópolis: Vozes. 1996.

DICIONÁRIO OXFORD de Arte. Tradução Marcelo Brandão Cipolla. Revisão Técnica Jorge Lúcio de Campos. Martins Fontes. São Paulo. 1996.

DIETRICH, Ana Maria. Caça as suásticas: O Partido Nazista em São Paulo sob a mira da Policia Política. Associação Editorial Maneta: Imprensa Oficial do Estado de São Paulo, FAPESP. 2007.

DINES, Yara Schreiber. Cidadelas da cultura no lazer: um estudo de antropologia da imagem do SESC São Paulo. Tese de Doutorado da Pontifícia Universidade Católica de São Paulo - PUC, 2007.

FERRARA, Lucrécia D’Alésio. “São Paulo, Brasil: da imagem local a identidade global”. In: SOUZA, Maria Adélia Aparecida de et alii. Metrópole e globalização: conhecendo a cidade de São Paulo. São Paulo, Cedesp, 1999.

FILIPPI, Patrícia de, LIMA, Solange Ferraz de, CARVALHO, Vânia Carneiro de. Como tratar coleções de fotografias. Arquivo do Estado/ Imprensa Oficial do Estado. 2 edição. São Paulo, 2002.

FREHSE, Fraya. Vir a ser transeunte, civilidade e modernidade nas ruas da cidade de São Paulo (entre o início do século XIX e o inicio do século XX). Tese do programa de 
Pós Graduação em Antropologia Social da Faculdade de Filosofia, Ciências e Letras da Universidade de São Paulo, 2004.

GERODETTI, João Emílio \& CORNEJO, Carlos. O litoral paulista nos cartõespostais e álbuns de lembranças. São Paulo: Solaris Edições Culturais, 2001.

GINZBURG, Carlo. Mitos, Emblemas, Sinais. São Paulo: Companhia das Letras, 1989. O queijo e os vermes: o cotidiano e as ideias de um moleiro perseguido pela Inquisição. São Paulo: Companhia das Letras. 1991.

INOUE, Luciana Massami. “A cidade de São Paulo e a habitação para o trabalhador (1942-1964).” In: Território e cidades: Projetos e representações, 1870-1970. CAMPOS, Cristina de, OLIVEIRA, Eduardo Romero de e GITAHY, Maria Lucia (orgs.). São Paulo: Alameda, 2011.p.p.165-188.

JORGE, Janes. Tietê o rio que a cidade perdeu: São Paulo 1890-1940. São Paulo: Alameda. 2006

JÚNIOR, Rubens Fernandes. De volta à luz: Fotografias da Coleção do Imperador D. Pedro II. Catálogo de exposição. São Paulo: Banco Santos; Rio de Janeiro : Fundação Biblioteca Nacional, 2003.

PITTORESCO, Antonio Saggese. Folder da exposição realizada no Instituto Tomie Ohtake. 2010.

KIM, Joon Ho. A fotografia como projeto de memória. Cadernos de Antropologia e Imagem, UFRJ, n.17, p.227-247. 2003.

KOSSOY, Boris. Dicionário Histórico-fotográfico brasileiro. São Paulo, Instituto Moreira Salles. 2002

. "O mundo portátil: estética e ideologia da representação fotográfica". In: Registros Fotográficos, Patrimônio e Memória da USP. PINHEIRO, Maria Lucia Bressan (org.) São Paulo, Editora da Universidade de São Paulo, 2010.

KRAUSS, Vivian Wolf. A cultura visual além da imagem: fontes escritas e orais na 
compreensão da cultura visual. III Encontro Nacional de Estudos da Imagem 03 a 06 de maio de 2011 - Londrina - PR, 2011.

LAMPARELLI, Celso Monteiro. O ideário do urbanismo em São Paulo em meados do século XX. O Pe. Lebret: Continuidades, rupturas e sobreposições. Conferência proferida no 3 Seminário de História da Cidade e do Urbanismo, realizado em São Carlos - SP, de 7 a 10 de setembro de 1994.

LANGENBUCH, Juergen Richard. A estruturação da grande São Paulo. Rio de Janeiro: IBGE. (1971).

LANNA, Ana Lúcia Duarte. Uma cidade na transição Santos: 1870-1913. São Paulo - Santos. Editora Hucitec - Prefeitura Municipal de Santos, 1996.

LEBRET, Louis-Joseph. "Sondagem preliminar a um estudo sobre a habitação em São Paulo”. Revista do Arquivo Municipal. São Paulo: Departamento de Cultura, 1951.

LEFÉVRE, José Eduardo de Assis. O transporte coletivo como agente transformador da estruturação do centro da cidade de São Paulo. Dissertação de mestrado. Faculdade de Arquitetura e Urbanismo da Universidade de São Paulo - FAU/USP, 1985.

LEITE. Miriam Lifchitz Moreira. "Retratos de família: imagem paradigmática no passado e no presente". In: O fotográfico, Etienne Samain organizador. EDITORA HUCITEC CNPq, São Paulo, 1998.p.p35-40.

LIMA, Solange Ferraz. XV Congresso Internacional de AHILA. Cartões postais e olhares estrangeiros: a imagem de São Paulo na produção dos fotógrafos Guilherme Gaensly e Werner Haberkorn. 2008. . "O circuito social da fotografia: estudo de caso - II". FABRIS, Annateresa (org.) In: Fotografia, Usos e funções no século XIX. Texto e Arte 3. Edusp. São Paulo. 1991.

LUNA, Francisco Vidal \& COSTA, Iraci del Nero da. A Estrada e o Desenvolvimento Econômico: a Estrada São Paulo-Santos, Anais do IX Simpósio Nacional da Associação dos Professores Universitários de História - Tema: O Homem e a Técnica, São Paulo, Vol. II, ANPUH, 1979. , p.p. 551 - 567. 
MACEDO, Silvio Soares e PELLEGRINO, Paulo Renato Mesquita. "Do éden à cidade: transformações da paisagem litorânea brasileira”. In: Turismo, Espaço, Paisagem e Cultura. Eduardo Yázigi, Ana Fani Alessandri Carlos, Rita de Cássia Ariza da Cruz (orgs.) 1996. São Paulo. Editora HUCITEC.

MAGAlHÃES, Erasmo D’Almeida. "Praia Grande e Mongaguá". In: A baixada Santista. Aspectos Geográficos. V. 3. Santos e as cidades balneárias. São Paulo: Editora da Universidade de São Paulo. 1965.

MAGNANI, José Guilherme. "Rua, símbolo e suporte da experiência urbana”. NAU Núcleo de Antropologia Urbana da USP. 2009. p.p. 1-3.

MOURA, Carlos Eugenio Marcondes de. (org.) Retratos quase inocentes. São Paulo SP NOBEL, 1983.

MARRAS, Stélio. A propósito de águas virtuosas: Formação e ocorrências de uma estação balneária no Brasil. Belo Horizonte: Editora UFMG. 2004.

MARESCA, Sylvain. "A reciclagem artística da fotografia amadora". Cadernos de Antropologia e Imagem, UFRJ, n.17, p.203-217. 2003.

MARRICHI, Jussara Marques Oliveira. "Uma breve exposição sobre o emprego das palavras caldas, cidade termal, cidades balneárias e estâncias hidrominerais para os estudos urbanos brasileiros”. Anais do XXVI Simpósio Nacional de História - ANPUH São Paulo, julho 2011. p.p 1-18.

MAUAD, Ana Maria. "Imagens de passagem: fotografia e os ritos da vida católica da elite brasileira, 1850-1950”. Cadernos de Antropologia e Imagem, Rio de Janeiro, 10(1). 2000. p.p.137-153.

MELLO, Luis Inácio de Anhaia. O plano Regional de São Paulo. Uma contribuição da Universidade de São Paulo para o estudo de um "código de ocupação licita do solo". São Paulo: 08 de novembro de texto mimeografado. 1954. 
- Urbanismo positivo e urbanismo negativo. As

modernas cidades inglesas". São Paulo: 09 de novembro de 1955, texto mimeografado. • "O Urbanismo... esse desconhecido". São Paulo:

Edições da Sociedade Amigos da Cidade, n. 11, agosto de 1952.

MENEZES, Ulpiano T. Bezerra de. "A crise da memória, História e Documento:

Reflexões para um tempo de transformações": In: Arquivos, Patrimônio e Memória. Trajetórias e perspectivas. SILVA, Zélia Lopes da. (org.). São Paulo: Editora UNESP: FAPESP, 1999.

. Memória e Cultura Material: Documentos

Pessoais no Espaço Público. Estudos Históricos. N. 21. Rio de Janeiro. 1998.

Fontes visuais, cultura visual, História visual:

Balanço provisório, propostas cautelares. In: Revista Brasileira de História. São Paulo, v. $23, n^{\circ} 45$, pp. 11-36 - jul. 2003. p.p.11-36.

MONBEIG, Pierre. [1949] Pioneiros e fazendeiros de São Paulo, 2 edição, HUCITEC, Polis, São Paulo, 1998.

MORSE, Richard. De comunidade a metrópole. Biografia de São Paulo. São Paulo: Comissão do IV Centenário da cidade de São Paulo. Serviço de comemorações culturais. 1954.

MOURÃO, Benedictus Mário. A Água Mineral e as Termas. Uma história milenar. São Paulo: Abinam. 1997. . Medicina Hidrológica: moderna terapêutica das águas minerais e estâncias de cura. Poços de Caldas, Ed. Prisma, 1992.

MUAZE, Mariana Ferreira. O império do retrato: família, riqueza e representação social no Brasil oitocentista (1840-1889). Tese de Doutorado do Programa de Pós-Graduação em História da Universidade Federal Fluminense (1840-1889). 2006.

NOGUEIRA, Oracy. Vozes de Campos do Jordão: Experiências Sociais e Psíquicas do Tuberculoso Pulmonar no Estado de São Paulo. Editora da Revista de Sociologia. 1950.

OWENSBY, Bryan. Intimate Ironies: Modernity and the Making Of Middle Class

Lives In Brazil. Stanford, California. Stanford University Press. 1999.

PEIXOTO, Clarice Ehlers. Antropologia e Imagem, vol. 1. PEIXOTO, Clarice Ehlers (org.) Garamond Universitária, FAPERJ, 2011.

PASSOS, Maria Lúcia Perrone. "Apresentação" In: Evolução Urbana da Cidade de São Paulo. Vol. I Estruturação de uma Cidade Industrial (1872-1945). Tomo I - Monografias, Série Bibliografias. Eletropaulo - Superintendência de comunicação. Departamento de Patrimônio Histórico de São Paulo. Secretaria Municipal de Cultura. 1990. 
PERALTA. Inez Garbuio. O impacto da industrialização sobre o desenvolvimento de Cubatão. Tese de Doutorado em História Econômica. Universidade de São Paulo (USP), São Paulo, 1979.

PEREIRA, Adriana Maria Pinnheiro Martins. A cultura amadora na virada do século XIX: a fotografia de Alberto de Sampaio (Petrópolis/Rio de Janeiro, 1888-1914). Tese de Doutorado do Departamento de História da Faculdade de Filosofia, Letras e Ciências Humanas da USP.

PEREIRA, Fabiana. "Domingo à tarde". In: Tietê mãe das águas. MEDINA, Cremilda (org.) São Paulo: CJE/ECA/ USP. 1995.

PINTO, Celma do Carmo. Fábrica de Anilinas. Prefeitura Municipal de Cubatão, 2009.

PIVOT, Cleide. O turismo e a produção social do espaço urbano. Estudos sobre Campos do Jordão - SP. Dissertação de mestrado em planejamento urbano e regional. Universidade do Vale do Paraíba. 2006.

POSSAMAI, Zita Rosane. "Narrativas fotográficas sobre a cidade”. Revista Brasileira de História. Vol.27, n53.p.p.55-90. 2007.

QUINTELA, Maria Manuela. "Curar e recrear em águas termais: um diálogo etnográfico entre Portugal (Termas de São Pedro do Sul e Termas da Sulfúrea) e Brasil (Caldas da Imperatriz)". Anuário Antropológico 2010-11. Dezembro de 2011.p.p.169-194.

."Saberes e práticas termais: uma perspectiva comparada em Portugal (Termas de S. Pedro do Sul) e no Brasil (Caldas da Imperatriz)". História, Ciências, Saúde - Manguinhos, Rio de Janeiro. 2004, p.p 239-260.

Cura termal: entre as práticas "populares" e os saberes “científicos”. VIII Congresso Luso Afro-Brasileiro de Ciências Sociais Coimbra. 2004, p.p 1-22.

RIBEIRO, Evanice Maria Högler. Os alemães dos núcleos coloniais de Santo Amaro e Itapecerica da Serra (1831/1914). Tese de Doutorado apresentada ao Departamento de 
História da Faculdade de Filosofia, Letras e Ciências Humanas da Universidade de São Paulo. 2002.

RODRIGUES. Adyr Ap.Balastreri. Águas de São Pedro - Estância Paulista. Uma contribuição à geografia da recreação. Tese de Doutorado, Departamento de Geografia, faculdade de Filosofia Letras e Ciências Humanas, Universidade de São Paulo, São Paulo, 1985.

ROUILLÉ, André. Fotografia entre documento e arte contemporânea. São Paulo, Ed. SENAC. 2009.

SABINO, André Luiz. Urbanização e turismo em Bertioga - o caso da Praia de Indaiá. Dissertação de Mestrado apresentado ao Departamento de Geografia da Universidade de São Paulo, FFLCH, Departamento de Geografia. São Paulo. 2007

SANTOS, Regina Célia Bega dos. Rochdale e Alphaville: formas diferenciadas de apropriação e ocupação da terra na metrópole paulistana. Tese de Doutorado do Departamento de Geografia da FFLCH-USP. 1994.

SEABRA, Odette Carvalho de Lima. A muralha que cerca o mar: uma modalidade de uso do solo urbano. Dissertação de mestrado do Departamento de Geografia da FFLCHUSP, 1979.

SEGALA, Lygia. "Coleção fotográfica de Marcel Gautherot", In: Anais do Museu Paulista. História e Cultura Material. Nova Série, n.2, Vol. 13, Jul-Dez. 2005).

SEVCENKO. Nicolau. Orfeu extático na Metrópole: São Paulo sociedade e cultura nos frementes anos 20. São Paulo. Companhia das Letras. 1992.

SILVA, Armando. Álbum de família: a imagem de nós mesmos. Tradução Sandra Martha Dolinski - São Paulo: Editora SENAC São Paulo: Edições SESC SP. 2008. 
SILVA, Dom José Gaspar de Afonseca e. Pastoral Coletiva do Episcopado de São

Paulo. Sobre alguns erros contra a fé e a moral. Oficinas Gráficas da "Ave Maria": São Paulo, 1941.

Pastoral Coletiva do Episcopado de São

Paulo Sobre a defesa da fé, da moral e da família. Oficinas Gráficas da "Ave Maria": São Paulo, 1940.

Pastoral de Saudação aos seus diocesanos.

Oficinas Gráficas da “Ave Maria”. 1939

SILVA, Maria da Glória Lanci. Os cenários do lazer: Turismo e Transformação da Paisagem Urbana. Tese de Doutorado. São Paulo. Faculdade de Arquitetura e Urbanismo da Universidade de São Paulo. 2003.

SILVA, Vagner Gonçalves da. Candomblé e Umbanda: Caminhos da devoção brasileira. 2. Ed. - São Paulo: Selo Negro, 2005.

SOMEKH, Nadia. A cidade vertical e o urbanismo modernizador. São Paulo 19201939. São Paulo: Estúdio Nobel. Editora da Universidade de São Paulo: FAPESP, Coleção Cidade Aberta, 1997.

SONTAG, Susan. Sobre a fotografia. Companhia das letras. 2004. SOUZA, Gilda de Mello e. "A luta das classes". In: O espírito das roupas: A moda no século dezenove. Companhia das Letras. São Paulo, 1987.

STRAUSS, Levi. “A ciência do concreto". In: O Pensamento Selvagem. Tradução: Maria Celeste da Costa e Souza e Almir de Oliveira Aguiar. Companhia Editora Nacional. Editora da Universidade de São Paulo. São Paulo. 1970.

SVEVO, Célia \& Sandra NOPETALSKI. O Toriba na cultura de Campos do Jordão. Metavídeo SP Produção e Comunicação Ltda. 2007.

TULIK, Olga. Residências secundárias: repercussões sócio-culturais. In: Turismo e Lazer: prospecções da fantasia do ir e vir. CORRÊA, Tupã Gomes (org.). São Paulo, EDICON, p.p.63-72. 1996. 
WERNET, Augustin. “As escolas alemãs no estado de São Paulo: um pequeno histórico". Manual de informações para o professor alemão. Doc. 16. Biblioteca da Faculdade de Filosofia, Ciências e Letras da USP. 1989.

URRY, John. O olhar do turista: Lazer e viagens nas sociedades contemporâneas. Studio Nobel: SESC. 1999.

VIEIRA, Imário. Turismo de Segunda Residência em Praia Grande (SP). Dissertação de mestrado apresentada ao Departamento de Geografia da Universidade de São Paulo. 2008.

VON SIMSON, Olga Rodrigues. "Imagem e memória". In: O fotográfico, Etienne Samain (org.) Editora HUCITEC CNPq, São Paulo. 1998.

WERNET, Augustin. "As escolas alemãs no estado de São Paulo: um pequeno histórico". Manual de informações para o professor alemão. Doc. 16. Biblioteca da Faculdade de Filosofia, Ciências e Letras da USP. 1989 